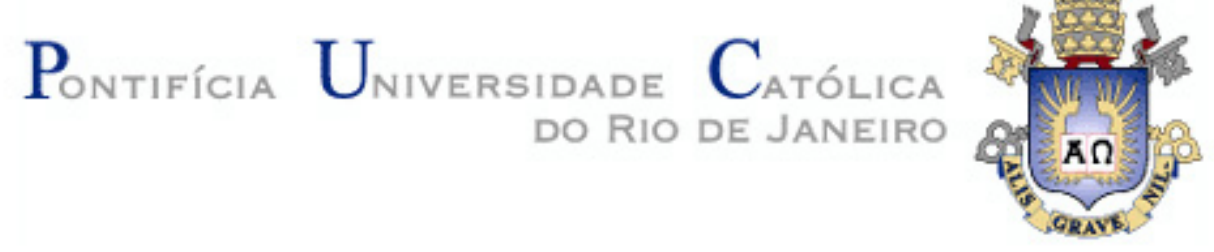

Luiz Henrique De Nadal

Da narrativa de fundação à fundação da narrativa: Leitura histórico-ficcional sobre a origem de uma cidade colonial com nome indígena

Tese de Doutorado

Tese apresentada ao Programa de Pós-graduação Literatura, Cultura e Contemporaneidade da PUC-Rio como requisito parcial para obtenção do título de Doutor em Letras.

Orientadora: Prof ${ }^{a}$. Dra ${ }^{a}$. Marília Rothier Cardoso

Rio de Janeiro

Abril de 2021 
Luiz Henrique De Nadal

\section{Da narrativa de fundação à fundação da narrativa: \\ Leitura histórico-ficcional sobre a origem de uma cidade colonial com nome indígena}

Tese apresentada ao Programa de Pós-graduação Literatura, Cultura e Contemporaneidade da PUC-Rio como requisito parcial para obtenção do título de Doutor. Aprovada pela Comissão Examinadora abaixo assinada.

Profa . Marília Rothier Cardoso

Orientadora

Departamento de Letras - PUC-Rio

Prof. Frederico Oliveira Coelho Departamento de Letras - PUC-Rio

Prof. Italo Moriconi

Departamento de Letras - UERJ

Profa. Arlene Renk Departamento de Ciências Ambientais - UNOCHAPECÓ

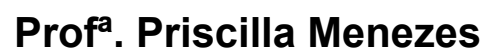

Departamento de Didática - UNIRIO

Rio de Janeiro, 27 de abril de 2021. 
Todos os direitos reservados. É proibida a reprodução total ou parcial do trabalho sem autorização da universidade, do autor e do orientador.

\section{Luiz Henrique De Nadal}

Mestre em Literatura Brasileira pela Uerj - Universidade Estadual do Rio de Janeiro Uerj (2014-2016). Foi pesquisador integrante do GPESq Vida, Arte, Literatura: Bioescritas e idealizador do site Perfis Literários. Realizou eventos literários junto de instituições como Casa das Rosas, SESC Rio e SP e foi colaborador da Revista Pessoa. Atualmente é pesquisador de Literatura Brasileira e participa do Núcleo de Dramaturgia FIRJAN/RJ.

Ficha Catalográfica

Nadal, Luiz Henrique De

Da narrativa de fundação à fundação da narrativa : leitura históricoficcional sobre a origem de uma cidade colonial com nome indígena / Luiz Henrique De Nadal ; orientadora: Marília Rothier Cardoso. - 2021. 286 f. : il. color. ; $30 \mathrm{~cm}$

Tese (doutorado)-Pontifícia Universidade Católica do Rio de Janeiro, Departamento de Letras, 2021.

Inclui bibliografia

1. Letras - Teses. 2. Fundação. 3. Narrativa. 4. História. 5. Arquivo. 6. Roteiro. I. Cardoso, Marília Rothier. II. Pontifícia Universidade Católica do Rio de Janeiro. Departamento de Letras. III. Título.

CDD: 800 


\section{Agradecimentos}

Meu primeiro agradecimento é para Marília, jardineira sábia que me ensinou a cuidar das folhas.

À CAPES, salvadora da pátria e à equipe do Departamento de Letras da PUC-Rio.

Aos professores das salas de aulas, das ruas e dos terreiros.

Aos caboclos das rodas de bailado e aos caboclos da minha terra natal.

À minha mãe e minha avó, que me deixaram as gargalhadas e o prato cheio.

Ao avô Zílio pela biblioteca, ao avô Carlos pelos causos e ao meu pai, quem me ensinou a bagunçar as palavras.

À vó Irma por querer me engordar até hoje e à tia Nega por ter emprestado a barriga.

Ao Luiz, por quem o amor não cabe nas palavras e uma única vida.

À Fabi, pela mesa de café sem fuso horário.

À Pri, pelo menino-onça e o espelho cristalino das praias do lençol.

À Iracema, pelos sonhos e telepatias.

À Êlo, pela infância.

À minha irmã Iza, pelo entusiamo.

Às mulheres de vozeirão e língua afiada: Tia Zozô, Valéria Monã, Ana Chiara, Cris Ribeiro e Sandra Terra.

Aos amigos atemporais, anacrônicos e vidas passadas: Sarah Lee, Tchela, Vuvú, Arthuzini, Juju, Helô, Lucas Xarapín, Bel, Pedrinho; e aos do bosque da Puc: Fefê, Aninha, Vaguta, Dani, Pedrinho Beija-Flor, Glaucia, Marina, Marcelo.

Aos colegas do Núcleo de Dramaturgia por fazerem da escrita estouro de boiada. 
O presente trabalho foi realizado com apoio da Coordenação de Aperfeiçoamento de Pessoal de Nível Superior - Brasil (CAPES) - Código de Financiamento 001. 


\section{Resumo}

NADAL, Luiz Henrique De; CARDOSO, Marília Rothier (Orientadora). Da narrativa de fundação à fundação da narrativa: Uma leitura histórico-ficcional sobre a origem de uma cidade colonial com nome indígena. Rio de Janeiro, 2021.286p. Tese de Doutorado - Departamento de Letras, Pontifícia Universidade Católica do Rio de Janeiro.

Esta pesquisa parte de um vestígio histórico: Caibi, palavra indígena com o qual foi batizada uma cidade de colonização italiana do extremo Oeste catarinense, região Sul do Brasil. Fundada a partir de uma colônia de descendentes de imigrantes europeus, na década de 1920, a história de fundação da cidade é contada no livro Caibi: Histórias e Memórias (2012) pelo ponto de vista dos chamados pioneiros, colonos ou pessoas “de origem”. Este último, modo pelo qual a população nativa de caboclos se referia aos novos ocupantes de suas terras. Interessado no lapso entre a narrativa oficial de fundação e os testemunhos do grupo que vivia anteriormente na região, descendente de indígenas, este trabalho faz um cruzamento entre as duas versões da história. Inicialmente, através de uma abordagem histórico-crítica sobre a narrativa local de fundação em que são utilizados estudos de revisão historiográfica, materiais de arquivos e entrevistas realizadas com os caboclos que vivem até hoje na cidade. Feita a releitura em torno da narrativa fundacional, outra parte do trabalho consiste na proposta de fundação de uma nova narrativa: um texto ficcional, no formato romance poético, que utiliza o material reunido para forjar uma nova origem para a cidade. A qual inclui caboclos e indígenas como personagens ao lado dos já conhecidos colonos. Além do caboclamento historiográfico realizado a partir do conceito de caboclo de Luiz Antônio Simas, estão presentes nesta discussão as noções de arquivo (Jacques Derrida e Michel Foucault), roteiro e performance (Diana Taylor), história e narrativa (Walter Benjamin).

\section{Palavras-chave}

Fundação; Narrativa; História; Arquivo; Roteiro. 


\section{Abstract}

NADAL, Luiz Henrique De; CARDOSO, Marília Rothier (Advisor). From the foundation narrative to the foundation of the narrative: historical-fictional reading about the origin of a colonial city with an indigenous name. Rio de Janeiro, 2021. Tese de Doutorado Departamento de Letras, Pontifícia Universidade Católica do Rio de Janeiro.

The starting point of this research is a historical trace: Caibi, an indigenous word that was given as the name of a city of Italian colonization in the far west of Santa Catarina. The city was officially founded in the 1920's, from a colony of the descendants of european immigrants. It's founding history is described in the book: Caibi: Histories and Memories (2012) from the point of view of the socalled pioneers, settlers or people "of origin". The latter - the expression used by the native population of caboclos to refer to the new occupants of their lands. Interested in the difference between the official foundation narrative and the testimonies of the group that originally lived in the region (descendants of indigenous people), this work compares these two versions of history. Firstly the research considers a historical-critical approach to the founding local narrative through the use of studies of historiographical review, archival materials and interviews with the caboclos who still live in the city. After looking back on the foundational narrative, another part of the work consists in the proposal to settle a new narrative: a fictional text, in the format of a poetic novel, which uses all the gathered material to create a new origin for the city - which includes caboclos and natives as characters alongside the already known settlers. In addition to the historiographical caboclamento realized from the concept of caboclo by Luiz Antônio Simas, the concepts of archive (Jacques Derrida and Michel Foucault), script and performance (Diana Taylor), history and narrative (Walter Benjamin) are also present in this discussion.

\section{Keywords}

Foundation; Narrative; History; Archive; Script. 


\section{Sumário}

1. O caboclo na roda do bailado

2. Da narrativa de fundação à fundação da narrativa

3. A viagem de 1929

3.1. Caboclamento historiográfico

4. O baile da onça: romance com notas

5. Referências Bibliográficas

271

6. Anexos

278 


\section{Lista de figuras}

Figura 1 - Fotografia dos integrantes da viagem de $1929 \quad 27$

Figura 2 - Fotografia do mapa com o trajeto da viagem de $1929 \quad 28$

Figura 3 - Fotografia do retrato de Adolpho Konder 33

Figura 4 - Fotografia do portal de entrada da cidade de Mondaí $\quad 37$

Figura 5 - Fotografia de Adolpho Konder proferindo discurso na sede

Cascalho 39

Figura 6 - Fotografia do retrato do sertão catarinense 40

Figura 7 - Fotografia do avô materno, prefeito de Caibi de 16/11/1965

a $30 / 01 / 1970$

Figura 8 - Fotografia do avô paterno, prefeito de Caibi de 31/01/1970 a 31/01/1973

Figura 9 - Fotografia do pai, prefeito de Caibi de 01/02/1983 a 31/12/1988

Figura 10 - Fotografia do autor durante o desfile do dia 7 de setembro, em 1990

Figura 11 - Fotografia da manchete Índios caigangue ameaçam invadir área no centro da cidade

Figura 12 - Fotografia do folheto dos Kaigang à população de Iraí $\quad 222$

Figura 13 - Fotografia da ilustração do menino-onça de Priscilla Menezes

Figura 14 - Fotografia da manchete Índios começam a demarcar terras

Figura 15 - Fotografia da manchete Índios fincam o primeiro marco

Figura 16 - Fotografia do comunicado dos Kaigang 
Onça é onça-feito cobra... Revira pra todo o lado, mercê pensa que ela é muitas, tá virando outras.

João Guimarães Rosa, escritor 


\section{O caboclo na roda do bailado}

Esta investigação começou com a fala de pajé João. Este homem branco que usava cocar e tocava teclado, quando participei de uma cerimônia de ayahuasca pela primeira vez, usou uma expressão que recupero para abrir este trabalho. Quando fui conhecer o centro espiritual Arca da Montanha Azul, vivia há apenas um ano no Rio de Janeiro. Numa sexta-feira à noite, desci do ônibus no alto do bairro de Santa Teresa. Uma longa fila de pessoas vestidas de branco estava em frente ao endereço. Vi aquela cena com o mesmo fascínio que sentia pelas festas populares desde que me mudara. Sempre deslumbrado em como as rodas de jongo e de côco, blocos de carimbó e de maracatu, festas de São Sebastião e São Jorge irrompiam nas ruas revelando outros mundos. Nesse corpoa-corpo com a cidade, o ritual daquela noite foi uma das experiências mais marcantes da minha vida. As cerimônias religiosas de ayahuasca são mediadas pelo uso deste chá com efeitos enteógenos ${ }^{1}$, tradicionalmente utilizado por xamãs ao longo de milênios. A Arca da Montanha Azul combina as mais diversas formas de ritualística, tradições religiosas e divindades. Das religiões de base judaicocristã aos cultos afro-indígenas até às práticas espirituais do Oriente. Trata-se de um estilo bastante comum entre os espaços que fazem uso medicinal 2 da bebida, dito universalista. Pajé João estava na linha de frente como um dos dirigentes da casa. Como um homem branco a quem foi conferido o título de chefia indígena, sua figura é bastante significativa dentro desta história.

Horas depois de beber o chá, parei diante da roda de bailado. Neste espaço, no meio do salão, os participantes dançavam em torno de uma pilastra, no sentido horário. O pequeno coro de vozes acompanhado por instrumentos percussivos cantava pontos de invocação, até então desconhecidos para mim. Sem nenhuma orientação prévia sobre os códigos e regras que todo rito religioso possui, impus a

\footnotetext{
${ }^{1}$ Enteógenos ou "plantas de poder" são assim definidos pela origem natural das substâncias, sem interferência farmacológica, e pelo uso ritualístico em diferentes tradições religiosas. São sempre associados à experiências visionárias e de expansão de consciência.

${ }^{2}$ A noção de medicina, usada de modo geral pelos frequentadores, é associada à cura espiritual.
} 
mim mesmo o lugar de observador. Ainda assim, estava fascinado com a intensa movimentação dos corpos. Ao dobrar os joelhos para sentar-me no chão, as articulações não obedeceram. $\mathrm{O}$ momento seguinte não permitiu nenhuma negociação sobre o domínio do meu corpo. Fui levado a entrar na corrente por uma força que me empurrou pela cintura. Apesar da intensidade daquele toque invisível que me conduzia, compreendi, com uma parcela de consciência, que cabia a mim permitir os movimentos que se insinuavam através do meu corpo. Nada me impedia de saltar fora da roda ou de bloquear o canal de contato com o desconhecido que acabara de se abrir. Essas considerações, contudo, só me ocorreram depois da experiência. A resposta imediata do meu corpo foi ceder à presença que imantava os meus movimentos, sugerindo que eu manifestasse os seus gestuais por inteiro. Eu estava dançando e meu corpo sendo dançado. Não havia nada naquela atuação que eu soubesse de antemão: a postura ereta, um braço dobrado para trás, acomodado à altura da lombar; o outro erguido para o alto com os dedos em riste a desenhar círculos no ar. Apesar do tremor, meus pés atendiam às batidas do tambor com uma convicção que nunca tive. Tempos depois, Pajé João, que acompanhou o meu retorno a outras cerimônias como aquela, haveria de se referir a minha presença na Arca da Montanha Azul usando sua forma de expressão particular: "Ah, aquele sujeito que encosta o caboclo!".

Antes que eu pudesse nomear a experiência daquela noite, Pajé João interpretou-a com uma compreensão bastante comum aos ambientes de culto religioso afroameríndio. $\mathrm{O}$ transe místico ou mediúnico é o estado que propicia a comunicação de um indivíduo com seres e forças desconhecidas, a exemplo das sempre mencionadas entidades de pretos-velhos, caboclos e pombagiras ${ }^{3}$. É verdade que o fenômeno da mediunidade recebeu, ao longo do tempo, inúmeras interpretações estigmatizantes. Em comum, entretanto, estas abordagens costumavam desconsiderar o contexto religioso em que aconteciam. No caso específico da Arca da Montanha Azul, onde a cerimônia toma emprestado

\footnotetext{
3 Para este trabalho, em que o assunto tem caráter secundário, será suficiente explicitar algumas noções básicas encontradas no artigo "Psicologia da mediunidade: do intrapsíquico ao psicossocial" (2009). Trata-se de um breve histórico dos estudos pioneiros sobre a mediunidade, abarcando desde as pesquisas científicas iniciais, que restringiam o fenômeno a aspectos intrapsíquicos, aos estudos mais recentes, abertos a uma perspectiva psicossocial. Disponível em: $<$ http://pepsic.bvsalud.org/pdf/bapp/v29n2/v29n2a03.pdf $>$ Acesso em: 15 mar. 2021.
} 
preceitos de religiosidades como a umbanda, o candomblé e até da encantaria, a experiência com as entidades espirituais é bastante comum e até estimulada entre os participantes. Além disso, em meados da década de 1950, os estudos antropológicos garantiram uma perspectiva sociológica e histórica para a análise das religiões mediúnicas no Brasil, preconizados por Roger Bastide e Pierre Verger. Compreensões deste tipo servem, aqui, não para uma interpretação do fenômeno vivido. E sim para um cruzamento de diferentes epistemologias que permitam construir conhecimento de modo singular. Visto que considero o episódio descrito inicialmente como gesto fundador desta escrita. Ora, foi justamente através dos caminhos que se abriram a partir daquela experiência que me deparei com o vestígio norteador desta investigação. De "encostar" um caboclo, sem fazer juízo sobre aquela manifestação dentro do contexto religioso, e apoiado na curiosa interpretação de Pajé João, passei para alguns estudos sobre a questão indígena. Cheguei a esboçar um projeto inicial de doutorado, cujo objetivo era o de construir uma trajetória de análise entre personagens índios da literatura nacional até o momento atual da virada etnográfica. Ao passo em que avançava com a proposta original, dividido entre a releitura de obras indigenistas, a descoberta de estudos etnográficos e a familiarização com trabalhos artísticos do universo indígena, finalmente atentei para o fato que mudou o norte desta pesquisa - o nome, também indígena, da minha cidade de origem.

É certo, contudo, que não estava diante de uma descoberta. O termo Caibi, traduzido por "folhas verdes" do tupi-guarani, é uma informação conhecida por grande parte dos habitantes da cidade. É provável que muitos caibienses já tenham lançado mão do curioso dado na tentativa de situar um lugar tão pequeno, com pouco mais de seis mil habitantes ${ }^{4}$, desconhecido até mesmo dentro do próprio estado $^{5}$. De modo geral, o uso do topônimo indígena, como referência, cria um efeito comum: a imagem da pequena cidade como algo muito antigo, resquício de tempos remotos, muitas vezes insondáveis - a julgar pela expressão recorrente dos

\footnotetext{
4 De acordo com o site oficial do município, o número de habitantes é de 6.130 (IBGE/2019). Disponível em: <https://www.caibi.sc.gov.br>. Acesso em: 15 mar. 2021.

5 Refiro-me ao estado de Santa Catarina, região Sul do Brasil. Dentro dos limites estaduais, a cidade está sediada no extremo Oeste catarinense, em oposição à região litorânea, onde fica a capital Florianópolis.
} 
curiosos. De modo totalmente contrário, não só a história da cidade é bastante recente, como também o nome foi instituído em um momento posterior a sua fundação. O que saltava aos olhos, enfim, na qualidade de novo, era o desacordo entre o nome oficial, de origem nativa, e uma evidente paisagem colonial, formada majoritariamente por uma população branca de descendentes de imigrantes italianos. Flagrava algo invisível aos meus olhos, até então. A naturalização daquela informação, repetida tantas vezes ao longo da minha vida, não deixava ver o seu lapso. O nome da cidade apareceu, desse modo, como um dado avulso e deslocado. Alheio às possíveis narrativas que o termo autóctone sugeria. Visto que não havia nenhum habitante indígena na cidade.

A experiência traduzida pelo entendimento de Pajé João, portanto, recupera inicialmente o gesto desencadeador desta investigação em torno do nome da cidade. Mas também retorna como um dispositivo de escrita. A cena do transe místico trazida de início, em que o meu corpo é tomado pelos gestuais da entidade espiritual conhecida como caboclo, prefigura a operação realizada a partir daquela investigação. A qual produz cruzamentos histórico-críticos e ficcionais entre os grupos representados na roda do bailado, os quais aparecem de maneira diferente na narrativa oficial de fundação da cidade. De um lado, os descendentes dos imigrantes italianos - conhecidos como colonos 6 - reconhecidos como pioneiros e únicos fundadores de Caibi. E que habitam, em grande parte, o centro da cidade. De outro, os caboclos que, embora tenham participado ativamente do processo de fundação, não foram incluídos na história da cidade. Além de viverem às suas margens como os indígenas, seus antepassados.

As próximas páginas apresentam 3 capítulos, a começar pela leitura à contrapelo do livro - capítulo 2 - que oficializa a narrativa de fundação da cidade do ponto de vista dos colonos, levantando vestígios de indígenas e caboclos. A análise sobre o modelo historicista e o uso de arquivos utilizados pela historiadora local aponta para outro tipo de abordagem dos arquivos e para uma nova forma narrativa. Ambas guiadas pelo conceito de caboclo, forjado por Luiz Antonio Simas. Em seguida, o capítulo 3 faz uma análise no episódio conhecido como

${ }^{6}$ A definição "colono" é empregada de modo generalizado na historiografia regional e se refere a todos os camponeses de origem europeia responsáveis pelo processo de colonização da cidade. 
Viagem de 1929. Considerado marco na historiografia regional e para a narrativa de fundação da cidade, os registros em torno do evento são lidos através da relação entre arquivo e repertório, prefiguradas por Diana Taylor, na tentativa de flagrar os roteiros que atualizam o legado colonial através dos tempos, definindo os papéis entre protagonistas e antagonistas. O capítulo 4 apresenta um texto ficcional no formato romance, acompanhado de notas de viagem, que experimenta a proposição de uma escrita em transe, apostando na invenção de uma nova forma narrativa que tenta expandir os limites da história de fundação. Por último, nos anexos, estão presentes alguns trechos das entrevistas feitas com os caboclos da cidade. 


\section{2}

\section{Da narrativa de fundação à fundação da narrativa}

O livro Caibi: histórias e memórias (2012) apresenta a história de formação da cidade pelo ponto de vista dos colonos. A historiadora Domingas Rizzi, autora do trabalho, é descendente dos chamados pioneiros e foi coordenadora do Setor de Cultura municipal à época. A obra teve o propósito de valorizar a trajetória desse grupo e, ao mesmo tempo, registrar o relato de suas experiências de forma oficial, como patrimônio histórico do município. O processo de organização das informações históricas para a escrita do livro envolveu o uso de documentos variados 7 , reportagens de jornais, objetos e fotografias pertencentes ao museu da cidade, além de uma bibliografia acerca da historiografia regional. Além dos itens de arquivo, o material mais importante para a escrita da história local foram as entrevistas gravadas pela pesquisadora com os colonos e seus descendentes. Todos eles, apesar das diferentes ocupações, fizeram parte do processo de colonização da cidade. Sendo este o tema central e ponto de partida para a pesquisa realizada por Rizzi (2012), quem acompanha a chegada das famílias de colonos na densa região de florestas, vindas das antigas colônias italianas do Rio Grande do Sul. Em seguida passa pela transformação do núcleo colonial em município, em que a gradativa especialização do trabalho agrícola e o desenvolvimento econômico são fundamentais. Até alcançar a condição de uma cidade nos termos modernos. Nessa espécie de narrativa fundacional, os colonos também têm o seu modo de vida apresentado pelo estudo. As práticas culturais, as memórias e o imaginário do grupo estão ligados aos antepassados italianos, embora a geração desses novos imigrantes, fundadores de Caibi, tenha nascido em terras brasileiras.

A homenagem prestada aos colonos pelo trabalho de fundação da cidade é um gesto incontestável. Os testemunhos que remontam aos tempos antigos são marcados por desafios que vão das longas viagens de mudança das famílias à instalação de moradias em lugares inóspitos e sem recursos. Por outro lado, o

7 A autora menciona alguns deles: documentos de legislação e emancipação do município, cadernos de atas da paróquia, livro de atas do hospital e dados do Tribunal Regional Eleitoral. 
livro traz uma questão incontornável para esta pesquisa ao evidenciar a importância da escrita na oficialização da história. Ángel Rama, em A cidade das letras (2015), afirma que o lugar exclusivo da escrita nas sociedades latinoamericanas era tão reverenciado que assumia uma aura de sagrado. $\mathrm{O}$ método adotado pela pesquisadora é exemplar para que uma determinada narrativa ganhe o selo de história oficial. Antes de serem considerados dados factuais, os relatos dos colonos entrevistados eram narrativas de domínio público, compartilhados informalmente nas casas e nos espaços de socialização. Para esse processo, a historiadora gravou entrevistas em áudio e vídeo "[...] com pessoas que presenciaram os fatos ou relataram as memórias narradas por seus pais" (RIZZI, s/ p, 2012), posteriormente transcritas e referenciadas no livro. Neste ponto, a crítica não se refere ao trabalho histórico de Rizzi (2012), mas à concepção moderna de história à qual ela adere, anterior ao estabelecimento da disciplina no século XIX. Inaugurado pela Escola Histórica Alemã, esse método conferiu caráter científico ao trabalho do historiador. Ao mesmo tempo, desperta constantes relativizações por parte da crítica decolonial por conta do ideal de verdade que defende. O desprestígio da oralidade e o apreço pela escrita são aspectos estruturantes do método, conforme Ricardo Benzaquen Araújo aponta no artigo "História e narrativa". O caso em questão, em que a historiadora realiza a transição das narrativas pertencentes ao plano da memória para o documento - renegando aquilo que vem da boca e dos ouvidos e produzindo uma versão confiável aos olhos e mãos - comprova a fragilidade dos fatos históricos, no que diz respeito à objetividade e neutralidade. Em tese, esta oposição dos fatos em relação à subjetividade, à fantasia e à ficção garantiria o paradigma da história factual, cronológica e linear. Ou, nas palavras de Leopold Von Ranke, historicista emblemático da escola alemã, a representação do passado tal como ele de fato foi.

Entretanto, o que sustenta a imagem dita verdadeira do passado da pequena cidade é - de acordo com o método científico do historicismo - a superposição de dois pontos de vista. Dos testemunhos que relatam suas experiências com objetividade e do historiador moderno, capaz de apresentá-las com isenção e neutralidade. Mais do que encarar a instabilidade desta operação, 
Walter Benjamin alerta o historiador desesperado por captar a verdadeira imagem histórica sobre a relação de empatia que estabelece na sua investigação. Para o autor, que defende o materialismo histórico como um rompimento com o método historicista, tal relação sempre se dá com os vencedores. O que pressupõe uma disputa de poder envolvida na escrita da história e uma ordem mantida pelo historicismo servil através dos tempos. "Ora, os que num momento dado dominam são os herdeiros de todos os que venceram antes. A empatia com o vencedor beneficia sempre, portanto, esses dominadores." (BENJAMIN, 1994, p. 225). Postulado pelo filósofo, o famoso gesto de escovar a história a contrapelo permite integrar a história cultural da cidade à história da luta de classes. Além disso, encontra uma semelhança possível no gesto que abre este trabalho, o da incorporação mística do caboclo no corpo de um descendente de colono. Trata-se de garantir que a escovação da narrativa fundacional, interessada no ponto de vista dos vencidos, dará a ver os pontos da história em que o caboclo "encosta" na cidade - conforme o vocabulário de Pajé João. Neste caminho, o trabalho histórico de Rizzi (2012) precisa ser lido com todas as suas contradições, independente do significado afetivo que possui. A começar pelo título - Caibi: histórias e memórias - que apesar de utilizar o substantivo "histórias" no modo plural, considera as experiências de um único grupo da cidade. Além disso, o termo memória é empregado como uma totalidade, sem a necessária elucidação sobre as suas falhas e faltas características. Assim, as histórias e memórias dos colonos figuram como única e verdadeira narrativa de fundação da cidade. Não é por outro motivo que a referência ao grupo aparece apenas de forma implícita no título, como se os colonos fossem um sinônimo de Caibi.

A identificação afetiva da historiadora com os colonos e a idealização de suas memórias enquanto totalidade da história local não são os únicos nós a enroscar nesta leitura a contrapelo - ou ainda, uma leitura incorporada do caboclo. Estes dois aspectos colocam em xeque a ideia do arquivo moderno enquanto repositório positivo e público do passado. Primeiramente, pela falsa impressão de que o seu uso não precisa de uma mediação. Como se o conteúdo supostamente estocado no arquivo conservasse um sentido único, independente de quem o 
acessasse. Ligado a isto, está a crença de que os documentos nele guardados corresponderiam a um testemunho integral do passado. Uma ideia difícil de sustentar quando se observa os procedimentos arquivísticos da investigadora que, depois de reunir os materiais disponíveis no museu da cidade, recorre ao arquivo regional ${ }^{8}$ para obter os dados faltantes à reconstrução do período histórico. Isto sem falar na produção das entrevistas com os colonos. Se, por um lado, o artifício supre as lacunas do arquivo local com informações mais precisas sobre a história de fundação da cidade, por outro, desmistifica a aura de inviolabilidade que possui. Uma vez que fotografias, objetos e documentos fornecidos pelo grupo entrevistado passaram a fazer parte do acervo sem nenhum tipo de problema.

Diante do exposto, o uso que Rizzi (2012) faz do arquivo local evidencia o paradoxo levantado por Jacques Derrida em Mal de arquivo: uma impressão freudiana (1995). O estudo identifica uma espécie de febre que invariavelmente se abate sobre o desejo de memória, acabando por destruir o próprio princípio do arquivo. Trata-se da tensão entre a procura da verdade e da origem, e a consistência dita fantasmática, imprecisa e espectral daquele último (PEDROSA; KLINGER; WOLFF, CÁMARA, 2018, p.35). Problema, este, que não se apresenta de forma exclusiva para a historiadora de Caibi, mas para os estudos de arquivo como um todo desde o advento da psicanálise. A qual enxerga o espaço arquivístico não como um repositório de memória, mas como a própria materialização - sempre precária e insuficiente - de sua falta originária e estrutural. (DERRIDA, 1995, p.22). Não obstante o objetivo de reconstruir o período de formação da cidade, afirmando uma origem oficial, o que se têm são documentos esparsos, dados faltantes e todas as lacunas que se abrem entre os restos do passado armazenados no acervo. A tensão dialética entre os polos da ordem e da desordem que deriva daí, comum à existência do colecionador, como observa Benjamin (1995) em "Desempacotando minha biblioteca", também está presente no trabalho do arquivista e do historiador. Para o filósofo-colecionador, todas as práticas de coleções e arquivamentos são determinadas pela relação que o sujeito mantém com os objetos, não pelos objetos em si. O livro de memórias da

8 O arquivo regional CEOM - Centro de Memória do Oeste de Santa Catarina está sediado na cidade de Chapecó. 
cidade, portanto, carregaria na sua forma de escrever a história, as marcas dessa contradição interna suturada pela voz aparentemente neutra do historiador. É como se a impressão freudiana, que acompanha o mal de arquivo no título de Derrida (1995), depositada inicialmente sobre o próprio arquivo do psicanalista e manifesta posteriormente nos conceitos de arquivo e de arquivamento, também deixasse suas marcas na historiografia.

Para além da identificação afetiva da historiadora local com os seus antepassados, o controle do arquivo emana um poder político comum na sociedade moderna. Haja vista que a sua disputa se deva à possibilidade de enunciar e construir um passado, não apenas a sua conservação. Não por acaso, o direito à interpretação arquivística é conferido à pesquisadora pela prefeitura municipal. O mesmo direito concedido aos antigos guardiões dos primeiros espaços físicos dos arquivos, os chamados arcontes. O retorno feito pelo autor aos antigos domicílios gregos que dão origem aos arquivos deixa ver a passagem institucional do privado ao público. "Depositados sob a guarda desses arcontes, estes documentos diziam, de fato, a lei: eles evocavam a lei e convocavam à lei." (DERRIDA, 1995, p.13). O modo pelo qual esses espaços que cruzavam aspectos topológicos e nomológicos, o lugar e a lei, o suporte e a autoridade, tornam-se visíveis e invisíveis ao mesmo tempo. Somada a essa função arcôntica primordial, e às funções de unificação e identificação, Derrida destaca ainda uma atribuição determinante nessa gestão do poder - a consignação. Esta, além de garantir a unidade do corpus arquivístico, reunindo-o em uma configuração ideal, imuniza o arquivo contra os segredos que possa conter e de tudo o que seja heterogêneo. Sugestionada desde a abertura deste trabalho, a pergunta sobre a presença de índios e caboclos no monumento moderno da cidade se impõe.

O capítulo inicial do livro apresenta de forma sumária outros dois grupos de habitantes que ocuparam a região antes da chegada das famílias colonizadoras. Primeiramente, passaram por lá etnias indígenas como os Guaranis, os Kaigang e os Xokleng, capazes de recuar os limites da história regional em até 600 anos atrás. Nessa breve apresentação, são indicados os diferentes responsáveis pela depopulação nativa ao longo do tempo. Os aldeamentos nas missões jesuíticas, as 
capturas pelos bandeirantes e, por último, o confinamento em aldeamentos mais recentes. Na sucessão dos indígenas, estão os seus descendentes caboclos. Uma população mestiça formada pelos mencionados grupos autóctones com escravos africanos, trazidos pelos grandes fazendeiros, que se instalaram na área, e trabalhadores de diversos estados brasileiros que aportavam na região. Durante anos, os caboclos ocuparam as vastas áreas de florestas sem possuir títulos de propriedade. O que se tornou um problema com o início do projeto de colonização. A partir de então, as empresas colonizadoras passaram a receber a posse dessas mesmas terras do governo estadual. Em contrapartida, selavam o compromisso de povoá-las com colonos descendentes de europeus. Por conta disto, os caboclos “[...] passaram a ser considerados um entrave para o 'progresso' desejado pelos setores dominantes" (RIZZI, 2012, p.12). A autora é cuidadosa ao acrescentar que a condição de "intruso" conferida ao grupo de nativos expulsos das suas terras vem sendo relativizada pelos estudos de revisão historiográfica. Embora as existências desses grupos não deixem de ser mencionadas pelo estudo, as violências a que foram submetidas são vistas como uma etapa necessária ao progresso que viria a seguir. E o espaço a elas reservado se limita à pré-história da narrativa de fundação da cidade.

O capítulo avança um pouco na trajetória desses dois grupos com a intenção de situá-los no tempo presente. Ainda hoje são encontrados vestígios da população indígena nos sítios arqueológicos da região, nas margens do rio Uruguai e nas terras dos colonos. As etnias remanescentes, como os Kaigang e os Guarani, vivem principalmente nas Terras Indígenas demarcadas. No que diz respeito aos caboclos, depois de serem expulsos de suas pequenas roças, o estudo informa que eles passaram a trabalhar para as próprias companhias colonizadoras, para as empresas madeireiras e para os colonos. Por mais que o cruzamento entre o grupo dos fundadores e os caboclos seja indicado neste ponto, não há nenhum desdobramento a este respeito no capítulo seguinte, que dá início à narrativa de fundação da cidade. De fato, basta uma caminhada pelas bairros mais afastados do centro, onde vive grande parte dos colonos e seus descendentes, para constatar uma das máximas de Benjamin - a de que o passado só pode ser compreendido à 
luz do presente. Os caboclos, afinal, sempre estiveram presentes. Desobedecendo ao limite estabelecido entre o capítulo inicial e os demais, avançaram da préhistória rumo ao mesmo caminho que o dos ditos pioneiros: a construção da cidade. Quanto aos indígenas, embora não vivam dentro dos limites de Caibi, a aldeia mais próxima está localizada a meio caminho da cidade vizinha de Iraí, a cerca de 20 quilômetros. Considerando os trabalhos subalternizados e as condições de vida precarizadas desses dois grupos, a pequena cidade colonial e sua história de fundação parecem confirmar novamente uma máxima benjaminiana. A de que nunca houve um monumento da cultura que não fosse também um monumento da barbárie. Na medida em que “[...] todos os bens culturais devem sua existência não somente ao esforço dos grandes gênios que o criaram, como à corvéia anônima dos seus contemporâneos." (BENJAMIN, 1996, p.225).

O testemunho sobre a origem do nome indígena Caibi consta no texto fundacional da cidade da mesma maneira que sempre correu nas conversas entre os colonos. Batizada de início como São Domingos, a cidade teve que escolher outro nome diante da curiosa coincidência de uma localidade vizinha também chamar-se São Domingos. A sugestão do nome indígena Caibi - cujo significado, já mencionado, é "folhas verdes" - veio do professor Júlio Turcatto, quem encontrou o verbete indígena em um livro. A ideia não era fazer referência ao grupo originário, mas simplesmente ilustrar a história contada pelos colonos com o termo tupi-guarani. Ao chegarem na região da futura cidade, os companheiros do professor só encontraram mato. Caibi, então, passou a designar não só a cidade, já em estado avançado de desenvolvimento, como também a paisagem original que a precedeu. Em O entre-lugar do discurso latino-americano (2000), Silviano Santiago aponta justamente para as cidades coloniais iguais a Caibi como um sintoma do renascimento colonial. Este processo de conversão dos habitantes originais do Novo Mundo em um único sistema sócio-cultural, inscreveu a América no contexto da civilização ocidental com o estatuto de um primogênito, diz o autor. Presos à condição de cópia e simulacro, restaria aos povos colonizados o valor máximo da semelhança em relação à metrópole: 
Pelo extermínio constante dos traços originais, pelo esquecimento da origem, o fenômeno de duplicação se estabelece como a única regra válida de civilização. É assim que vemos nascer por todos os lados essas cidades de nome europeu cuja única originalidade é o fato de trazerem antes do nome de origem o adjetivo 'novo' ou 'nova': New England, Nueva España, Nova Friburgo, Nouvelle France etc. (SANTIAGO, 2000, p. 14)

Embora o caso de Caibi não seja tão explícito como o da vizinha Nova Veneza, pode até ser compreendido como uma dupla cópia. Primeiro por haver surgido com o nome do padroeiro católico São Domingos, levado às terras catarinense pelos colonos descendentes de italianos. E, depois, por adotar um nome indígena através de uma abordagem folclórica, esvaziado do seu significado original. Marcas de homogeneização como esta, que levaram o autor a questionar qual o tipo de contribuição cultural a América Latina seria capaz no cenário ocidental, abrem a questão principal desta investigação. Como se daria uma nova leitura sobre os arquivos que enunciam a narrativa oficial de fundação da cidade? Tendo em vista que a origem da cidade é, ao mesmo tempo, o apagamento de outras origens possíveis e irrecuperáveis, de que modo seria possível ampliar os limites da narrativa de fundação? Santiago (2000) aponta um caminho no encalço do mestiço, esta figura por ele considerada subversora dos conceitos de unidade e pureza impostos aos latino-americanos. Na medida em que o mestiço - assim como o caboclo - configura uma mistura entre o elemento europeu e o elemento autóctone, seria capaz de produzir uma espécie de infiltração progressiva do pensamento selvagem. Ou seja, uma abertura que poderia levar à descolonização.

Para além da condição de grupo social dessas figuras, o trabalho do historiador Luiz Antônio Simas oferece um olhar sobre os caboclos que se manifestam nas rodas de bailado, giras e canjiras ${ }^{9}$. Ao analisá-los em expressões religiosas como na umbanda, no candomblé e na encantaria, articula o saber das chamadas macumbas a uma crítica do pensamento ocidental. Na sua elaboração, o caboclo é apresentado como uma categoria epistemológica capaz de promover o

\footnotetext{
9 Os três termos se referem a diferentes contextos ritualísticos em que o caboclo comparece
} enquanto um ser invisível. 
reposicionamento histórico e a emergência de saberes renegados pelo modelo racionalista. Pois que o caboclamento seria uma experiência de encante, ou encantamento a partir destes últimos. Para apresentar o caboclo enquanto conceito, Simas (2018) percorre diferentes religiosidades afro-indígenas a fim de escolher uma tipologia entre tantas. O "radical caboclo" (p.99), segundo ele, está presente na chamada encantaria. Esta manifestação religiosa pouco conhecida e anterior à umbanda, é considerada base e raiz desses seres ${ }^{10}$. Extraídas do seu contexto religioso, as características constitutivas de um caboclo encantado ${ }^{11}$ são sugeridas como faculdades especiais, por assim dizer, para reler o legado colonial. Exemplo elucidativo da experiência de encantamento, dado pelo historiador, é o caso do povo indígena tupinambá. Consta na narrativa oficial, pelo ponto de vista dos descobridores, que o grupo foi exterminado nas areias da Baía da Guanabara. Já pela via do encante ou do caboclamento, os tupinambás continuam a se manifestar nas rodas de macumba, incorporando-se nos corpos em transe. Ao afirmar o caboclamento enquanto uma experiência de encantamento, o autor sugere o encante como chave de leitura para reler história de formação do Brasil. Visto que a resposta dada por essas alteridades diante da tentativa de aniquilação dos colonizadores, é um desvio astucioso das mortes físicas e simbólicas que sofreram. O qual não consta nos registros escritos, mas nas oralidades dos terreiros de macumba.

No embalo desse pensamento, então, ser encostado pelo gestual do caboclo na roda do bailado, ter o corpo atravessado por sua temporalidade anacrônica, permite supor uma leitura de arquivo em busca de possíveis cruzamentos entre a narrativa oficial e os personagens soterrados pelo tempo

\footnotetext{
10 A Encantaria é considerada base e raiz dessas entidades, segundo conta o dirigente Francelino de Shapanan no artigo "Entre caboclos e encantados: mudanças recentes em cultos de caboclo na perspectiva de um chefe de terreiro" (2011). A razão, levantada por Simas (2018) e confirmada por Shapanan (2011), é a maior preservação da ancestralidade de uma prática em relação a outra. "A umbanda é bem posterior à encantaria de nobres e caboclos e por isso vemos suas entidades como derivações branqueadas daquelas que são cultuadas no tambor-de-mina, ou ainda como encantados-caboclos descendentes." (p.329)

11 Diferentes dos caboclos da umbanda e do candomblé de caboclo, os caboclos encantados são considerados seres supraviventes. Nem viventes, nem espíritos. Vivem na condição de elementos da natureza em que foram encantados e se manifestam nos corpos em transe. Estão para além da nossa concepção de vida biológica, filosófica e histórica. (SIMAS, 2018, p.101)
} 
vazio e homogêneo do historicismo ${ }^{12}$, confinados nas frestas do nexo causal dos fatos. Nesse sentido, a tipologia do caboclo encantado resgatada por Simas (2018) possui uma característica conveniente. $\mathrm{O}$ termo caboclo, na encantaria, serve para dar nome a todos os seres invisíveis que baixam no terreiro. Diferente da umbanda, por exemplo, em que o termo se restringe às entidades ligadas aos indígenas ${ }^{13}$. Por conta disso, o historiador defende que a chamada "canjira dos encantados" possui uma ontologia desafiadora ao projeto de dominação colonial. Já que os caboclos encantados não respeitam as hierarquias deixadas pelo legado colonial:

\begin{abstract}
$\mathrm{Na}$ canjira dos encantados todas as mais diferentes formas baixam sob a condição de caboclos. Essa horizontalidade se dá, pois parte-se da premissa de que tudo que está a circular no mundo está passível de encantamento. A noção de caboclo é o suporte que encarna as formas de vida potencializas pelo encante. Das princesas turcas aos beberrões maltrapilhos, do rei de França aos bugres guerreiros, dos vulgos matutos das campinas e sertões, às mais diferentes expressões de seres viventes. Na canjira dos encantados todos podem baixar sob o estatuto ontológico do caboclo. (SIMAS, 2018, p. 99)
\end{abstract}

Estruturada nos moldes do historicismo ocidental, a narrativa de fundação da cidade estabelece uma imagem eterna do passado, conectada aos arquivos da história regional e nacional. Ao considerar uma nova leitura desses arquivos, incorporada da noção de caboclo enquanto categoria epistemológica, o caboclamento arquivístico e historiográfico decorrente desta operação faz pensar também em um modo de escrita. Uma escrita guiada pelo caboclo seria, assim, uma escrita em transe - do latim "transire" - definida, portanto, "[...] pela ideia do ir atravessando como sentido de cruzar mundos, perspectivas, possibilidades, práticas, o tempo inteiro.” (p.100). Uma escrita disponível à travessia e ao cruzamento, em que o transe se configura como um ato criativo. Tanto na descoberta de materiais e narrativas eliminadas pelo poder arcôntico, expandindo

\footnotetext{
12 BENJAMIN, Walter. Sobre o conceito de história. In: Magia e técnica, arte e política: ensaios sobre literatura e história da cultura. Trad. Sérgio Paulo Rouanet. 7. ed. São Paulo: Brasiliense, 1994. p. $222-232$

${ }^{13}$ São exemplos: Caboclo Tupinambá, Caboclo Pena Branca, Caboclo Cobra Coral.
} 
o arquivo local. Quanto na ampliação dos limites da paisagem da narrativa de fundação, subvertendo-a no sentido de uma fundação narrativa que crie cruzamentos entre colonos, caboclos e indígenas; entre a história nacional e a história local, entre historiografia e ficção.

Antes de passar ao experimento proposto, o capítulo seguinte faz uma leitura do episódio conhecido como a Viagem de 1929. Considerada marco da historiografia regional e ponto de partida para a narrativa de fundação da cidade, o evento será analisado através das relações entre arquivo e repertório apresentadas por Diana Taylor, na tentativa de demonstrar os mecanismos dos roteiros coloniais e das performances que promovem a atualização de uma ordem social hierarquizada. Ao mesmo tempo em que assombrações dos indígenas se fazem presentes e caboclos caminham pelas margens e frestas dos documentos históricos. 


\section{A viagem de 1929}

O episódio conhecido como $A$ viagem de 1929 possibilita expandir a compreensão sobre a história da pequena cidade na medida em que eleva a discussão local ao nível regional e nacional. Os registros que virão a seguir, tornam visíveis pontos de contato entre a construção narrativa da cidade e a elaboração do projeto de grande nação, que atravessa o domínio regional através do plano de expansão territorial mediante a interiorização do país. Em articulação com o processo de corte e modelagem do povo, a produção da brasilidade e do sentimento nacional. Com efeito, a relação entre o referido evento oficial e a história de fundação da cidade permite tomá-la como célula da nação brasileira, então em franco desenvolvimento. Trata-se, pois, de um projeto de promoção da integração ancorada à ideia de construção da identidade estadual e brasileira (CEOM, 2005, p.137).

Distante da sede administrativa do estado, localizada em uma zona fronteiriça e comandada por mandatários locais, a desconhecida região do Oeste catarinense - designada como sertão - foi palco para uma espécie de encenação da conquista do seu território e da sua população. A historiografia regional parece consensual em considerar o evento como seu ponto zero. O que, além de comprovar a eficácia dos arquivamentos em torno do acontecimento, revela a filiação da história local de Caibi e de outras cidades da região, fundadas por colonos. E que constróem suas narrativas fundacionais a partir do mesmo marco temporal. 
Figura 1 - Fotografia dos integrantes da viagem de 1929

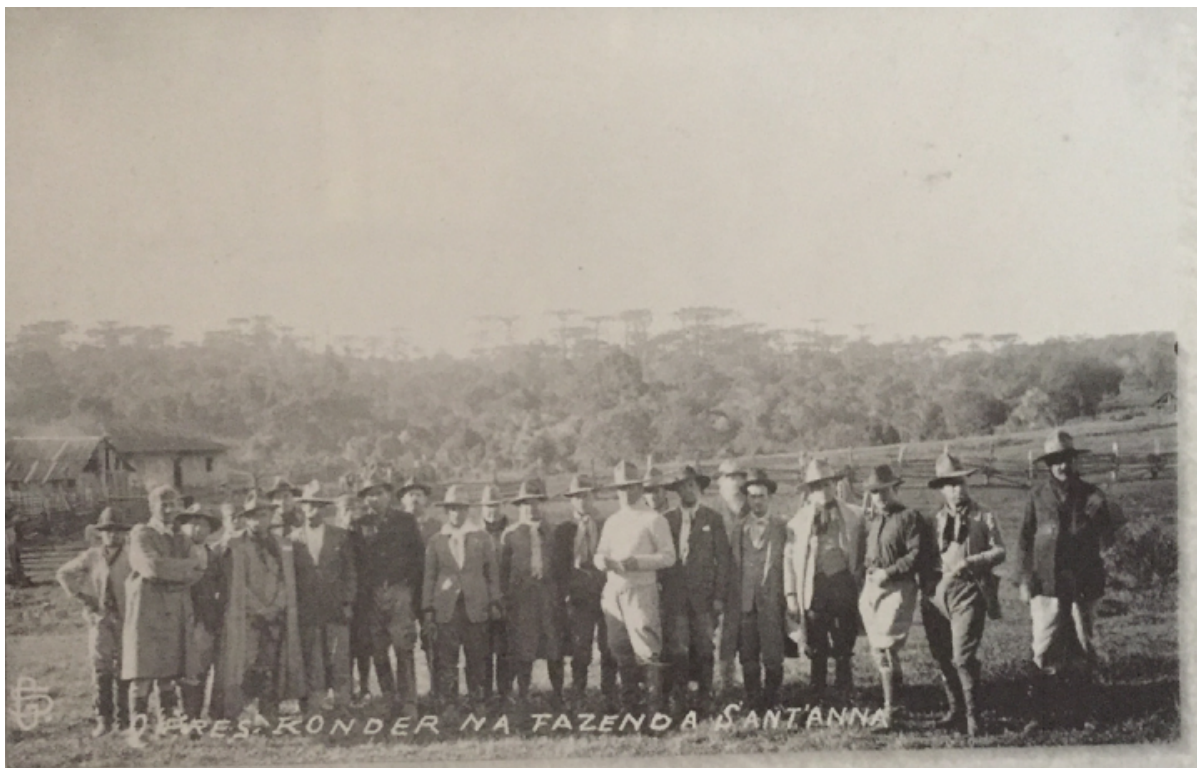

Fonte: Fac-símile do livro A viagem de 1929 (2005).

A viagem de 1929 foi realizada na forma de uma comitiva com cerca de 30 integrantes - homens dos mais variados cargos e segmentos do governo estadual como deputados, chefes de polícia, consultores jurídicos, agrimensores, historiadores e escritores - e encabeçada pelo governador de Santa Catarina, Adolpho Konder, à época, com o título de presidente do estado. Além de reunir nomes de prestígio, a caravana realizou um trajeto de 30 dias ${ }^{14}$ passando por cerca de 30 municípios, grande parte deles nas áreas de fronteira com os estados do Paraná (ao Norte), Rio Grande do Sul (ao Sul) e limite com a Argentina (a Oeste), perfazendo cerca de 3 mil quilômetros. Os quais foram percorridos com diversos meios de transporte, do simples automóvel a trem, ônibus, burros e cavalos, balsas e lanchas e, por fim, longas caminhadas pela área de floresta, coração do sertão catarinense.

\footnotetext{
${ }^{14} \mathrm{O}$ período exato e número de municípios visitados varia de acordo com os diferentes registros. A referida marca de trinta dias, carregada de um efeito emblemático, é de Arthur Ferreira da Costa, em publicação posterior à viagem, que será apresentada a seguir.
} 
Figura 2 - Fotografia do mapa com o trajeto da viagem de 1929

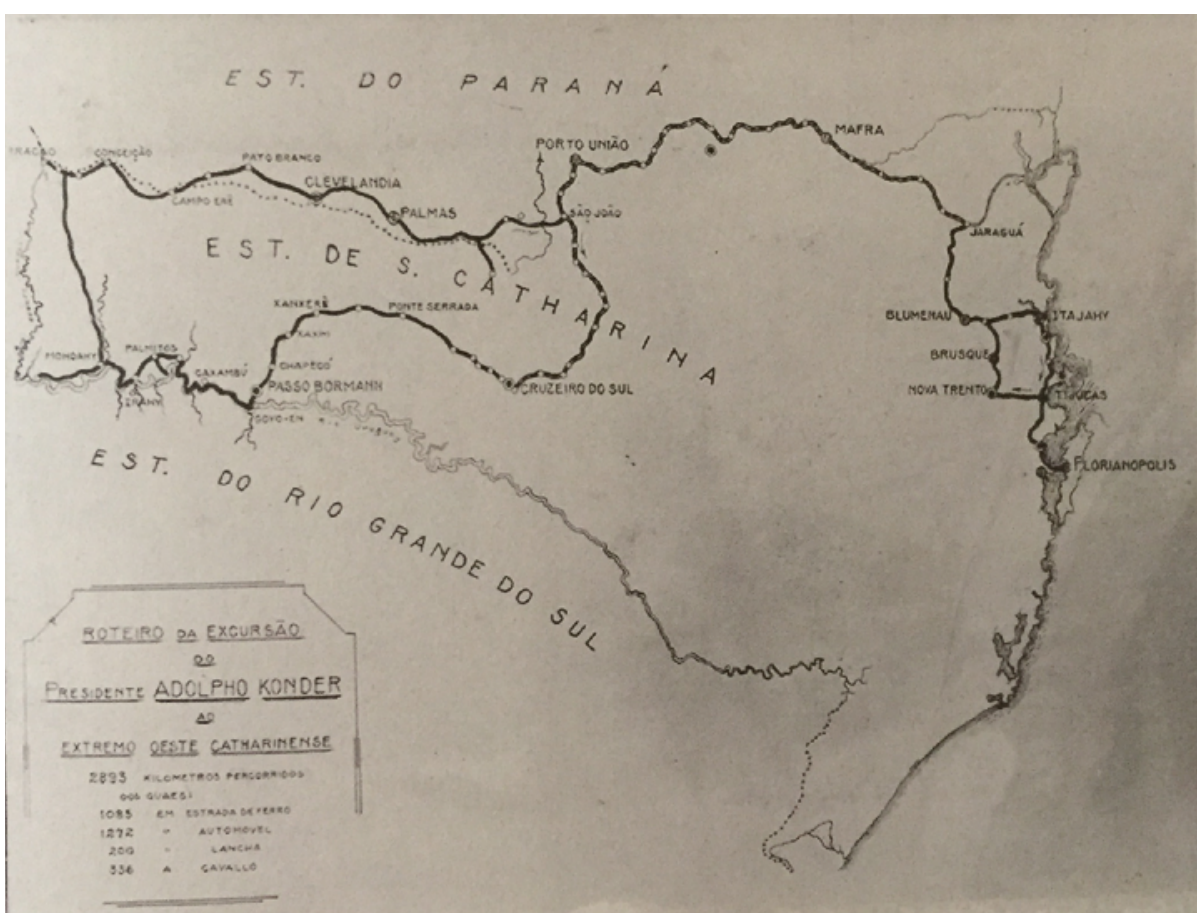

Fonte: Fac-símile do livro A viagem de 1929 (2005).

A imagem do mapa, em que é possível observar o trajeto da incursão, com início na capital catarinense, Florianópolis, em abril de 1929, consta em uma das publicações realizadas em torno do episódio, intitulada $O$ Oeste catharinense: visões e suggestões de um excursionista (1929), de Arthur Ferreira da Costa. Parte dos relatos que compõem a edição, escritos pelo chefe de polícia do estado no mandato de Konder, havia sido publicado periodicamente no jornal República, inteirando a população do litoral sobre as façanhas e adversidades enfrentadas pelo presidente e seu grupo. O governo estadual teria a preocupação de difundir o evento ao máximo através de um considerável aparato propagandístico. E rápido: o material foi reunido e publicado em livro no mesmo ano ${ }^{15}$. Também ganharia versão impressa a conferência proferida por José Arthur Boiteux, outro integrante do corpo oficial, antigo juiz de direito e desembargador do estado, que leva a público as obras e as promessas realizadas pelo governo ao longo da viagem. Oeste Catharinense (de Florianópolis a Dionisio Cerqueira) (1931) foi realizada

15 Os fac-símiles desta publicação e da conferência de Arthur Boiteux, que será apresentada na sequência, estão presentes no livro A viagem de 1929: Oeste de Santa Catarina, documentos $e$ leituras (2005), organizado pelo Centro de Memória do Oeste de Santa Catarina - CEOM. 
no Centro Catharinense e na Sociedade de Geographia, no Rio de Janeiro, e no Club XII de Agosto em Florianópolis. A transcrição do evento foi lançada em 1931 pelo Instituto Histórico e Geográfico de Santa Catarina - permitindo reconhecer o parentesco com o gesto primeiro do Instituto Histórico Brasileiro, o qual, logo após a independência do país, surge com o propósito de fundar os primeiros arquivos da nação e construir a memória nacional. O tipo de trabalho que implicava em "[...] recriar um passado, solidificar mitos de fundação, ordenar fatos buscando homogeneidades em personagens e eventos até então dispersos." (SCHWARCZ, 1993, p.129). À época de 1929, ainda, foi produzido e publicado o livro Aos espanhóis confinantes (1929), romance em formato de diário de viagem de Othon Gama D'Eça, um dos fundadores da Academia Catarinense de Letras. Por último, foi posto em circulação um álbum de fotografias que captura a presença dos integrantes da caravana, a paisagem e a população local.

No caso da narrativa fundacional da cidade, a montagem se dá através da manipulação de arquivos já existentes. Dos quais o livro publicado, além de referenciá-los, passa a fazer parte desses mesmos arquivos. De modo diferente, na viagem de 1929 é possível olhar para o arquivo em franco funcionamento. O que é possível através da cuidadosa inscrição do episódio em formato de escrita. Em suas reflexões sobre o arquivo e o repertório ${ }^{16}$, Diana Taylor lembra do papel histórico da escrita introduzido durante a Conquista da América espanhola. Na sua opinião, o legado deixado pelo evento, marcado pela imposição de documentos escritos como modo de controle da população indígena, não foi a substituição da escrita em relação às práticas relativas ao corpo. Assim como estas eram ferramentas utilizadas pelos jesuítas, também aquela era cara aos astecas, maias e incas, que cultivavam formas diversas de escrita aliadas à oralidade. O que mudou, de acordo com o raciocínio da autora, foi o grau de legitimação da escrita em relação a outros sistemas epistêmicos e mnemônicos. Algo que não se resume, portanto, à ruptura entre a palavra escrita dos colonizadores e a palavra falada dos nativos. Mas entre as noções antagônicas do arquivo, enquanto repositório

16 Como repertório, Taylor (2013) designa o conjunto de práticas e conhecimentos incorporados como performances, gestos, oralidade, movimento, dança, canto. (p.49) 
supostamente neutro de materiais duradouros. E do repertório, como efemeridade incapturável. Logo, o caso da viagem de 1929 serve, aqui, para desmistificar esta oposição entre arquivo e repertório e perceber a mediação que está por trás da construção da memória arquival, operada através dos dois domínios. Se, por um lado, o repertório das populações locais é banido, sem acesso ao mesmo sistema de escrita para legitimar a própria narrativa. Por outro, o mecanismo arquivístico está intimamente ligado à práxis incorporada. Ainda que esta seja registrada de forma estática e aparente ser uma manifestação incompatível com os documentos oficiais. Não por acaso, a performance comparece em diferentes níveis na construção narrativa do passado regional. Algo fácil de notar na atualização que promove dos arquivos nacionais. Estes que, por sua vez, trazem uma ordem social que remonta a sua fundação. Portanto, a apresentação pública da comitiva oficial do governo é, também, uma encenação dos gestos dos heróis da nação, conforme a apresentação do livro de Arthur Ferreira da Costa:

\footnotetext{
Essa jornada, verdadeira 'bandeira' empreendida nos dias que vivemos, tem características de coragem, de ousadia, de resistencia, de abnegação, que lembram os gestos de nossos maiores, quando se internavam pelos sertões, desbravando o desconhecido e levando aos rincões mais afastados o cunho da conquista brasileira, assegurando pela posse largos dominios para a nossa nacionalidade. (COSTA, 1929, s/p)
}

Os 3 registros escritos em torno do evento mostram um perfeito alinhamento entre os integrantes da Bandeira Konder ao se referirem, entre si, através do título de honra de bandeirantes. Dentre todos, o chefe da expedição, o governador Adolpho Konder, é considerado “[...] lidimo e intrepido 'bandeirante' [...]"“ (ibid., s/p). Também assim, na coletividade, o grupo é exibido à população do litoral como “[...] BANDEIRANTES DA BRASILIDADE, na phrase, sob todos os pontos de vista feliz, de Tito Carvalho, distincto jornalista conterrâneo, director da Republica e destacado membro da Academia Catharinense de Letras" (BOITEUX, 1931, p.28, grifo do autor). O contorno dessas personagens também se mostra um tanto criativo, por assim dizer, na sua construção. Ao perfil heroico de Othon Gama D'Eça, por exemplo, soma-se a 
insígnia de escrivão das caravelas do descobrimento, ao ser descrito por José Boiteux como "[...] Pero Vaz de Caminha da Bandeira catarinense do século XX" (ibid., p.14). É também Boitex, o desembargador versado na história nacional da caravana, que faz referência à emblemática frase do cronista Pero de Magalhães Gândavo $^{17}$. De quem a interpretação sobre um grupo de população indígena, no século XVI, é estendida para a população de brasileiros - os assim chamados caboclos - que viviam na zona considerada de maior desnacionalização 18 do sertão catarinense.

Ao registrar a importância da encenação da conquista do território em artigos e livros, o representante da cultura letrada apresenta o "roteiro" (Taylor, 2013) da ação dos corpos presentes por uma perspectiva que destaca, como heroísmo, a dominação - geralmente violenta - da população iletrada. Assim, as performances europeizadas legitimam seu autoritarismo pelo registro arquivístico. O qual será mantido na transposição do roteiro e da sua reiteração. Dentro dessa lógica, a população de caboclos da região fronteiriça - que fala uma mistura de português e castelhano, que não usa moedas nem jornais brasileiros e que casa e registra os filhos em cartórios vizinhos - repete o papel de população "brasílica" (COSTA,1929, s/p). E ocupa novamente o lugar subalterno diante do colonizador como um povo "Sem justiça, sem lei, sem escola" (GÂNDAVO, 1573, p.65).

A repetição do legado da história colonial visto no episódio de 1929 conduz, em tempo, à pergunta feita por Silviano Santiago - "Por que e para que

17 No seu Tratado da Terra do Brasil (1573) - reeditado em 1858 pela Revista do Instituto Histórico e Geográfico Brasileiro - no capítulo intitulado "Da condição e costumes dos índios da terra", o cronista faz a seguinte descrição sobre a população nativa: "A língua deste gentio, toda pela Costa, é uma: carece de três letras - não se acha nela F, nem L, nem R, cousa digna de espanto por que assim não têm fé, nem lei, nem rei; e desta maneira vivem sem justiça e desordenadamente".

Disponível em: < https://www2.senado.leg.br/bdsf/bitstream/handle/id/188899/

Tratado $\% 20 \mathrm{da} \% 20$ terra $\% 20 \mathrm{do} \% 20$ Brasil.pdf?sequence=1> Acesso em: 17 mar. 2021 .

18 A localidade em questão é uma zona de tríplice fronteira, à época com confusos limites e jurisdições entre duas cidades de estados brasileiros, Santa Catarina e Paraná, e uma terceira, pertencente à Argentina. Para dar contorno nacional à porção catarinense, inúmeras medidas foram tomadas: nomeação de oficiais de força pública, de registro civil, organização de diretório político local, agendamento de eleições distritais e criação de escolas primárias. Mais tarde, as 3 cidades seriam emancipadas, respectivamente, como Dionísio Cerqueira, Barracão e Bernardo de Irigoyen. 
viaja o europeu?"19. A resposta dada, - a colonização pela propagação da Fé e do Império - assinala o traço narcísico que contém. $\mathrm{O}$ do europeu que queria ver a sua imagem repetida por todo universo e que, assim, acaba por inaugurar a história dita universal (SANTIAGO, 2002, p.226) - omitindo-se, entretanto, a presença de quem mais pudesse estar presente. De volta ao momento inicial de construção da memória nacional, quando da criação do Instituto Histórico e Geográfico do Brasil, é possível detectar traços determinantes de um modelo historiográfico primordial - ou, como dirá Taylor (2013), a existência de um "roteiro". No afã imperial de produzir um projeto histórico unificador, em 1840, o instituto anunciou um concurso que escolheria um plano para se escrever a história antiga e moderna do Brasil. O ensaio premiado, intitulado Como se deve escrever a história do Brasil (1845), teve autoria do austríaco Karl Friedrich Von Martius, conhecido pela participação nas expedições científicas do século XIX e suas contribuições à historiografia e etnologia. Embora Von Martius (1845) não fosse historiador de formação e seu trabalho não apresentasse um programa de rigorosa metodologia histórica e científica, ainda assim, firmou-se como ponto de partida para vários trabalhos futuros. Engajado na construção de uma cultura nacional, atribuiu à mestiçagem - pela primeira vez - o valor de matriz da brasilidade (SOMMER, 2004, p.179). Por mais que defendesse a contribuição de indígenas e africanos para a formação da população brasileira, recomendando o estudo da cultura autóctone à historiografia pragmática, a hierarquia entre os três grupos é nítida para os olhos de hoje. E ainda assim, alerta Sommer (2004), a união racial em que os europeus iriam melhorar as raças ditas inferiores não era de todo diferente ao massacre dos povos indígenas, defendido abertamente por radicais como Francisco Adolfo de Varnhagen ${ }^{20}$. Na lição de Von Martius (1845), realizada pela caravana de 1929, o lugar central da historiografia está reservado ao colono português na sua múltipla condição: “[...] descobridor, conquistador e senhor [...]" (p.442). As façanhas marítimas, comerciais e guerreiras,

\footnotetext{
19 SANTIAGO, Silviano. Por que e para que viaja o europeu? In: Nas malhas da letra: ensaios. Rio de Janeiro: Rocco, 2002. 221-240p.

20 Disponível em: <http://www2.senado.leg.br/bdsf/handle/id/242428> Acesso: 17 mar. 2021.
} 
consideradas fundamentais no programa expositivo sobre o período de descobrimento e colonização do Brasil, são revividas nos gestos e na caracterização dos heróis catarinenses.

Além de trazer inúmeras camadas de relatos coloniais ao registro do presente, o estilo narrativo dos escrivães de 1929 está de acordo com as indicações feitas pelo naturalista alemão. Este, sugere evitar a monotonia das crônicas e investigações históricas, “[ ...] sêcas e puramente eruditas” (p.457). Na sua opinião, para a materialização de um projeto unificador, o “[...] autor monárquico-constitucional" (p.457) deveria prestar serviço a sua pátria e escrever a história nacional em um só volume, com linguagem popular e gênero épico. Ao futuro autor, que fosse escrever a história de acordo com o seu modelo, Von Martius desejou sucesso na tentativa de imprimir à obra todo o seu zelo patriótico “[...] e aquele fogo poético próprio da juventude, ao mesmo passo que desenvolva a aplicação e profundidade de juízo e de firmeza de caráter, pertencentes à idade madura e varonil." (p.458). A julgar pelo retrato do maior responsável pela "obra de brasilidade mais empolgante desses últimos anos de República" (D’EÇA, 1992, s/p), os auspícios de Von Martius (1845) se concretizaram:

\section{Figura 3 - Fotografia do retrato de Adolpho Konder}

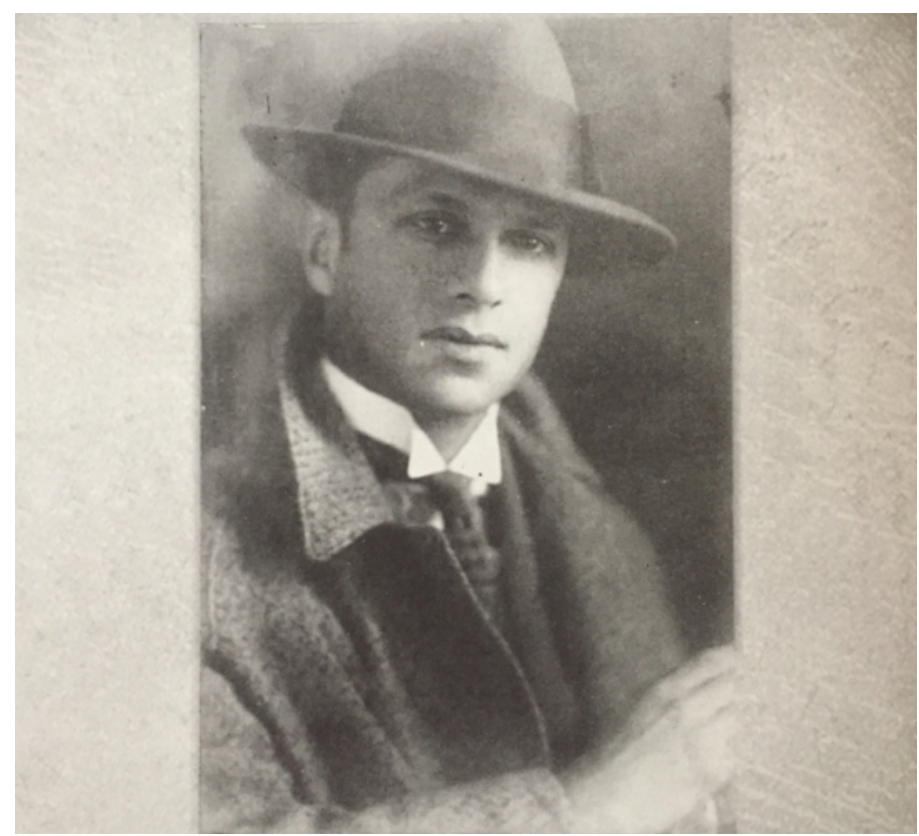

Fonte: Fac-símile do livro A viagem de 1929 (2005). 
As reincidências de traços e caracteres fundacionais identificadas na viagem de 1929 evidenciam, igualmente, a noção de roteiro trazida por Taylor (2013). Na forma mesma de sumário ou esboço de uma peça, com informações sobre cenas, personagens e situações - que excedem o texto e a narrativa -, os roteiros funcionam como paradigmas que estruturam a compreensão. Através do seu aspecto de instrumentalidade e transitividade, moldam-se a novos contextos organizando ambientes sociais, comportamentos e ações. Von Martius (1845) confirma a existência de inúmeros roteiros de descobrimento e conquista, na hora em que sugere ao "historiador patriótico" que procure "atrativo variadíssimo":

[...] na narração das numerosas viagens de descobertas e incursões dos diferentes pontos do litoral para os desertos longínquos do interior (os sertões), empreendidas em procura de ouro e pedras preciosas, ou com o fim de cativar e levar como escravos os indígenas. Essas entradas foram pela mejor (sic) parte executadas espontâneamente por pessoas, as quais animadas por um certo espírito romanesco e aventureiro, nelas desenvolveram tôda energia, talento inventivo, perseverança e coragem de um Cortez, Balboa ou Pizarro, e executaram façanhas dignas de admiração da posteridade." (VON MARTIUS, 1845, p. 452, grifo meu)

O roteiro, assim, seria uma espécie de arcabouço portátil que acumula repetições ao longo do tempo. Sua base de dados, por assim dizer, permite conduzir o rumo de ações futuras a partir de encenações passadas. $\mathrm{O}$ caso da expedição, uma verdadeira teatralização do roteiro de conquista, permite observar a estruturação do evento. Legitimados pela tradição, os bandeirantesconquistadores são imediatamente situados como aqueles que vêem e controlam a cena. Ao leitor dos jornais, transportado a um lugar exótico, é dada a mesma perspectiva. Ambas com recuo em relação à moldura que se impõe às desconhecidas terras e aos estranhos nativos, que serão posicionados às margens da paisagem e irão assumir características imaginárias ou substituição de inimigos antigos. Para que esse regime de visibilidade seja instaurado, para que seja realizada a transferência de roteiros antigos ao tempo presente, coisas específicas precisam ser ditas e feitas. 
O exemplo da performance da descoberta do Novo Mundo, usada por Taylor (2013), desempenhada por Colombo ao fincar a bandeira e recitar declarações oficiais rodeado por sinais de autoridade, também vale nesse caso. Uma vez que a performance, preservada no repertório e no arquivo, e que funciona como uma espécie de selo de legalidade para a reivindicação de posse, só exige dos sucessores bandeirantes a repetição do mesmo modelo "ao vivo." (p.96).

Nessa operação em que roteiros anteriores funcionam como moldura que possibilita a transferência do repertório para o arquivo, reconfigura-se o mapa ${ }^{21}$ do interior catarinense. A um só tempo é redesenhado no plano jurídico, seja com a ajuda técnica de engenheiros e geógrafos, seja com a implementação de medidas político-administrativas; além de ser retraçado no campo simbólico. Assim, as mudanças registradas no papel também são vistos nos registros fotográficos das reuniões com autoridades, nos encontros com líderes locais, nas visitações aos núcleos coloniais em expansão. A produção dessa nova paisagem conta, ainda, com uma ritualística nacionalizante. Em todas as localidades por onde passa, a caravana é recebida com bandeiras tremulantes, casas enfeitadas de verde e amarelo e demonstrações cívicas de patriotismo. O escrivão e bandeirante Gama D’Eça traduz uma dessas manifestações:

\begin{abstract}
A recepção ao presidente foi uma confortadora prova do sadio nacionalismo da sua população. Bandeiras nacionais nas mãos das crianças e, no ambiente luminoso, o rumor de um povo que deixara, por uns momentos, as lides da terra, para vir aclamar o chefe de Estado, que ia integrar uma porção querida de Santa Catarina nos destinos comuns da Pátria brasileira. (D’EÇA, 1992, p. 57)
\end{abstract}

Discursa-se sobre a importância daquele projeto para a consciência nacional, hasteia-se a bandeira, canta-se o hino. Na mesma linha, as obras - ou marcos civilizatórios - que vão sendo inaugurados, demarcam, progressivamente, um território nacionalizado. Escolas ganham o nome de autoridades, herois da

\footnotetext{
21 Othon Gama D'Eça menciona os ajustes feitos no mapa com um pouco mais de detalhes, se comparado aos outros dois registros: "Aproveitando a oportunidade e no afã de identificar verdadeiramente a região percorrida, o presidente, o Breves, e o dr. Werner fizeram retificações topográficas e hidrográficas, dando nomes a lajeados, a ribeirões, a acidentes naturais, que ainda nem se achavam assinalados nos mapas!" (D’EÇA, 1992, p.84)
} 
pátria são monumentalizados nas praças, ruas remetem a episódios históricos e rios passam a rememorar datas comemorativas do calendário nacional. As cidades, por sua vez, têm o nome original substituído por uma linguagem abrasileirada, associada ao caboclo e ao indígena - abraçados no novo imaginário da nação. A este respeito, o homem de letras da caravana explica:

\footnotetext{
Como é vasto e desconhecido este nosso querido Brasil! Mas, ao batizar essas águas novas, o presidente tem tido uma nobre preocupação nacionalista: dá-lhe sempre nomes brasileiros: - Lajeado do Saci, Ribeirão da Bracantinga.

Nada de designações arrevesadas, que o caboclo não pode pronunciar e nada significam.

Estamos no Brasil e o vocabulário brasileiro é farto e expressivo.

E o manancial luso-guarani inesgotável e belo, como nenhum outro. (ibd., p.84)
}

Ainda no encalço da perspectiva anti-colonialista de Taylor (2013), cuja proposta é observar o "roteiro" das ações performáticas, o uso de vocabulário local para identificar acidentes geográficos corresponde ao mesmo movimento autoritário de incorporação pelo Estado. De modo que territórios ainda habitados apenas por caboclos e indígenas sejam possuídos pelo empreendimento de colonização e seus representantes descendentes de europeus. A usurpação do território das populações nativas - como aconteceu no século XVI - é legitimada pela apropriação de suas denominações. Os registros mostram dois casos parecidos ao de Caibi. As colônias Porto Novo e Porto Feliz, próximas da área onde também surgiria São Domingos ${ }^{22}$, são renomeadas com topônimos indígenas semelhantes, por sugestão do governador. Respectivamente, passam a se chamar Itapiranga e Mondaí23. Embora o núcleo colonial que origina São Domingos tenha sido fundado tempos depois, é certo que a consolidação do imaginário nacional, então em formação, haveria de influenciar a substituição pelo nome de Caibi. Em

22 Cabe relembrar que a antiga São Domingos corresponde à futura Caibi.

23 Segundo Costa (1929), Mondaí, então, contava com 7 anos de funcionamento e Itapiranga, dois - confirmando o rápido desenvolvimento. Em relação a esta última, é interessante o trabalho de Paulo Eidt, intitulado Os sinos se dobram por Alfredo (2016), em que reconstitui a história do projeto de Porto Novo através do personagem ficcional Alfredo, integrante de uma família de imigrantes alemães. A narrativa mescla documentos, relatos de vida e estudos sobre as relações culturais, econômicas e sociais.

EIDT, Paulino. Os sinos se dobram por Alfredo. 2. ed. Chapecó: Argos, 2016. 376p. 
reforço a esta ideia, o comentário de Boiteux (1931) insinua que, a certa altura, as trocas de nomes começaram a acontecer espontaneamente:

\begin{abstract}
Ahi terminou a nossa viagem pelo rio. Deixámos as lanchas a gazolina e tomámos autos para visitarmos Porto Novo. Sua séde é a risonha Itapiranga, nome indígena como são Mondahy e tantos outros que os novos colonizadores daquella região estão preferindo aos Neu Bremen, Neu Berlim, Neu Breslau que tanto nos arrepiam os pavilhões auriculares e as Novas Venezia e Novas Palermo que, em cada canto colonizado por antigos directores de nucleos, se encontram seguidamente. (p.22).
\end{abstract}

Longe da espontaneidade sugerida pelo desembargador, a troca de nomes coloca em cena os efeitos do endurecimento da política adotada pelo futuro governo Vargas, direcionada em defesa do nacionalismo de inspiração nazifascista (DIWAN, 2018, p.119). Virado o jogo, os colonos europeus, antes beneficiados com as medidas de incentivo do governo, passariam a representar uma ameaça à unidade cultural e identitária pretendida pelo Estado Novo.

Figura 4 - Fotografia do portal de entrada da cidade de Mondaí

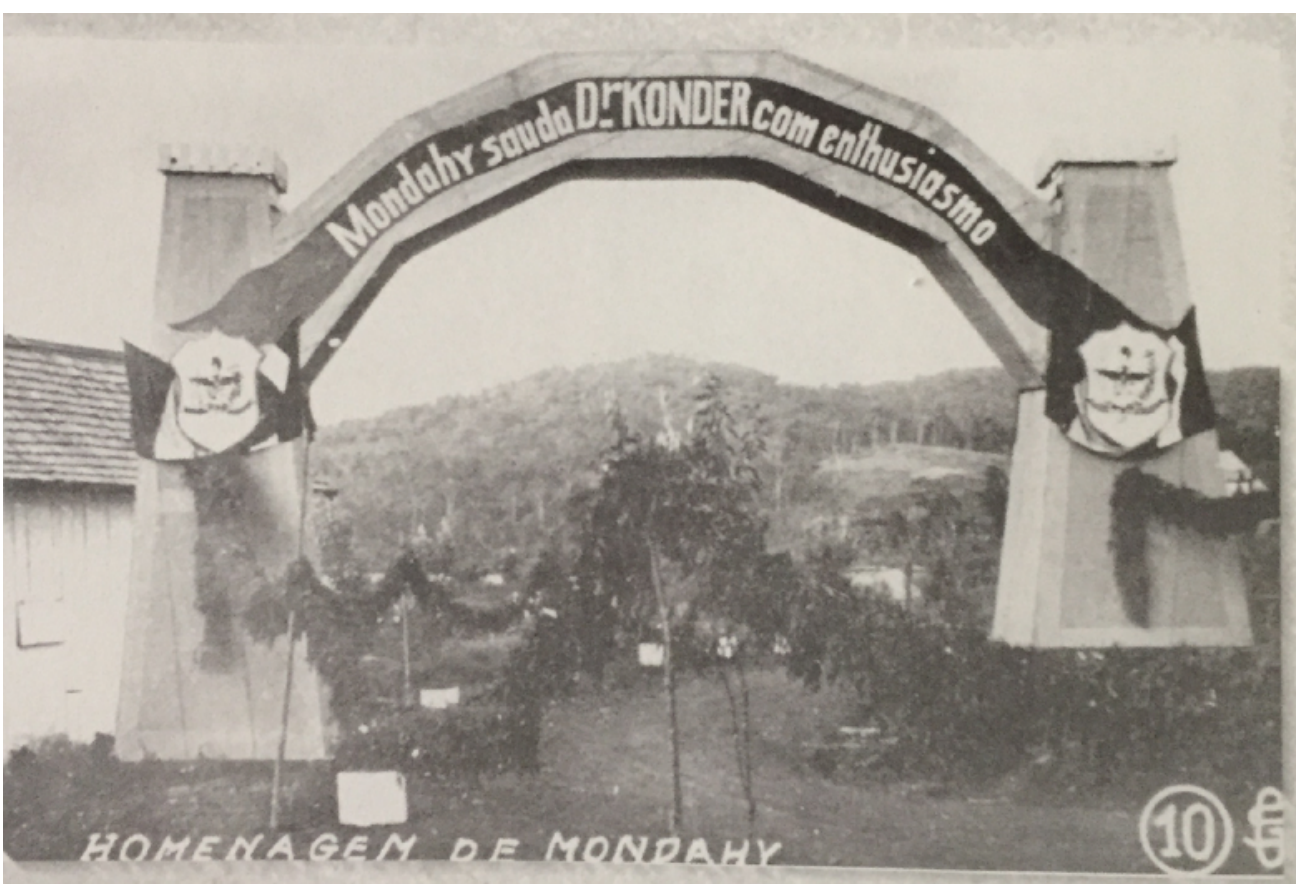

Fonte: Fac-símile do livro A viagem de 1929 (2005). 
No momento em questão, São Domingos não configurava um destino dentro da rota da caravana Konder. Como já mencionado anteriormente, foi necessário mais tempo para que o núcleo colonial ganhasse corpo, embora as primeiras famílias já vivessem naquelas terras desde 1918. Ainda assim, o trajeto da comitiva passa por sedes coloniais mais recentes em comparação a Itapiranga e Mondaí, as quais, além de se tornarem vizinhas de São Domingos mais tarde, abrigaram, de início, alguns dos seus integrantes. Em comum, todas essas pequenas comunidades - Palmitos ${ }^{24}$, São Carlos e Passarinho - foram administradas pelas empresas colonizadoras Chapecó-Pepery Limitada e a Companhia Territorial Sul Brasi125. Em um dos registros fotográficos, Adolpho Konder aparece em visita realizada a uma quarta sede vizinha, em estágio parecido, chamada Cascalho. O discurso feito na ocasião - "Quando o dr. Adolfo exclamou: 'Colonizar não é vender terras!' e acentuou a necessidade de se fixar o homem à gleba, houve exclamações e aplausos por toda a parte." (BOITEUX, 1931, p.47) - faz elogios ao trabalho realizado pela Companhia Territorial Sul Brasil. E, sobremaneira, à toda população de colonos imigrantes. Estes, que serviram indistintamente aos "futurosos núcleos de colonização" (BOITEUX, 1931, p.15) aos olhos do governo, serão oficializados com o mesmo estatuto de pioneiros na narrativa de fundação de Caibi, aos olhos de Rizzi (2012).

\footnotetext{
Passarinho, como Palmitos, como São Carlos, são colméias ativas, onde uma gente próvida e sadia vai construindo o seu favo de oiro. Vale a pena vê-las. Alimentam-nas uma gleba de feraz; orientam-nas espíritos de elite, com a consciência lúcida e nítida dos destinos humanos. (D’EÇA, 1992, p. 34)
}

\footnotetext{
${ }^{24}$ Palmitos, entre todas, a mais próxima de Caibi: separadas por pouco mais de 10 quilômetros.

25 Caibi teve sua construção capitaneada pela Companhia Territorial Sul Brasil. O estudo do historiador Antonio Werlang, de título Disputas e ocupação do espaço no Oeste catarinense: a atuação da Companhia Territorial Sul Brasil (2006) aborda o processo de colonização regional a partir do caso específico desta empresa e oferece rico material de fotos e entrevistas.

WERLANG, Alceu Antonio. Disputas e ocupação do espaço no Oeste catarinense: a atuação da Companhia Territorial Sul Brasil. Chapecó: Argos, 2006.149p.
} 
Figura 5 - Fotografia de Adolpho Konder proferindo discurso na sede Cascalho

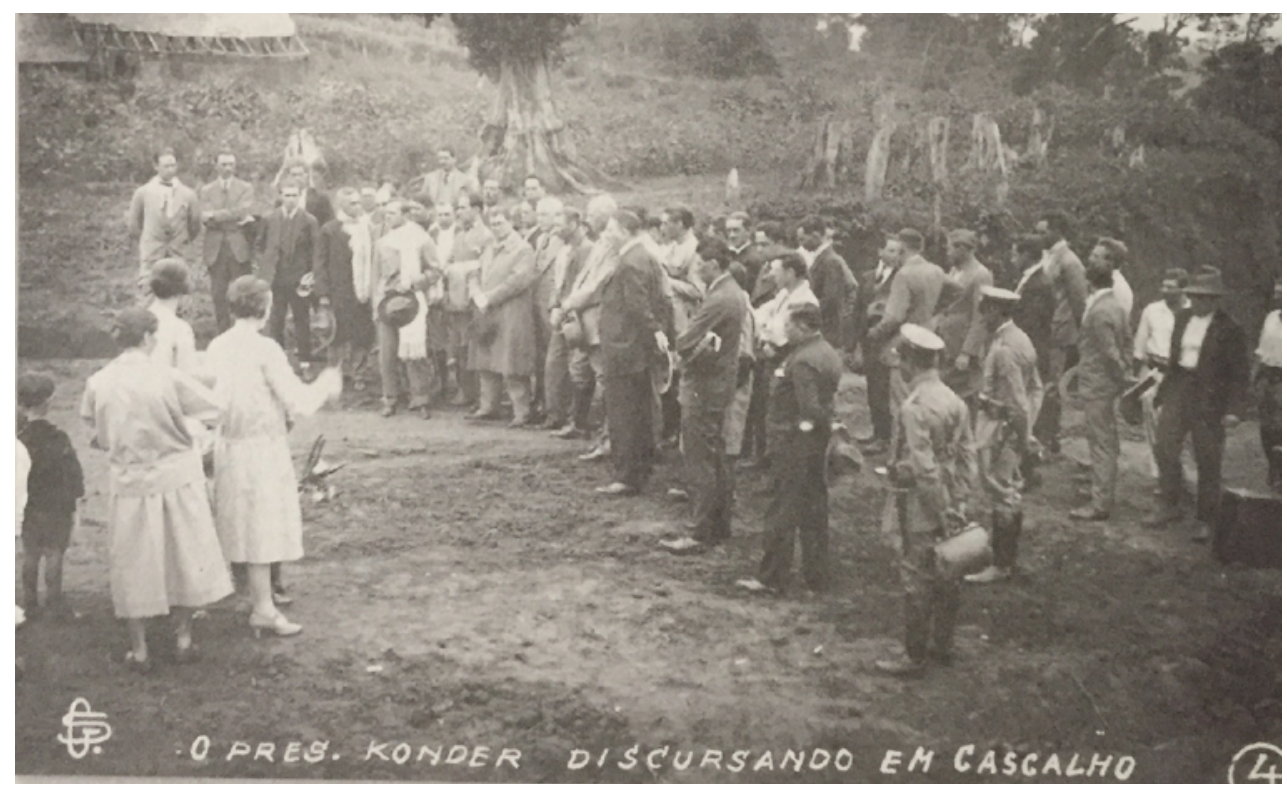

Fonte: Fac-símile do livro A viagem de 1929 (2005).

O arquivo regional mostra-se, assim, como a construção de um a priori histórico, um precedente (FOUCAULT, 1987, apud Pedrosa, Klinger, Wolff, Cámara, 2018, p. 22) em relação à história de fundação de Caibi. E cada vez mais longe da noção tradicional de arquivo, como lugar de memória e acumulação, revela-se um sistema enunciativo cujo controle garante poder político e a supremacia cultural. As fórmulas publicitárias e a retórica das notícias de jornais locais que passam a estimular a vinda de imigrantes das Colônias Velhas do Rio Grande do Sul26 para a "Nova Canaã", com base nos relatos e nos discursos de Konder, são nítidas construções de realidade. Entretanto, entre a moldura do arquivo e a paisagem, entre o éden e o sertão, entre os colonos e as populações nativas, persiste a tensão que marca todos os modos de arquivamento. E é a própria eficácia do arquivo da viagem de 1929, forjado como narrativa totalizante, como história do triunfo da lei e da ordem, como afirmação e repetição do modelo historiográfico nacional, que é necessário reler através de um caboclamento

26 Em Mito e história na colonização do Oeste catarinense (2008), Renilda Vicenzi discute os mitos criados em torno das personagens envolvidas no processo de colonização regional pioneiros e nativos - e analisa os discursos difundidos nas Colônias Velhas pela Cia Territorial Sul Brasil.

VICENZI, Renilda. Mito e história na colonização do Oeste catarinense. Chapecó: Argos, 2008. $162 \mathrm{p}$. 
historiográfico. Conjurando os fantasmas e espectros dos indígenas e seguindo os passos dos caboclos, que estão nas margens e nas frestas da paisagem do imenso sertão. Conquistado pelos bandeirantes catarinenses sob o regime de visibilidade assegurado pelos roteiros coloniais.

\section{Figura 6 - Fotografia do retrato do sertão catarinense}

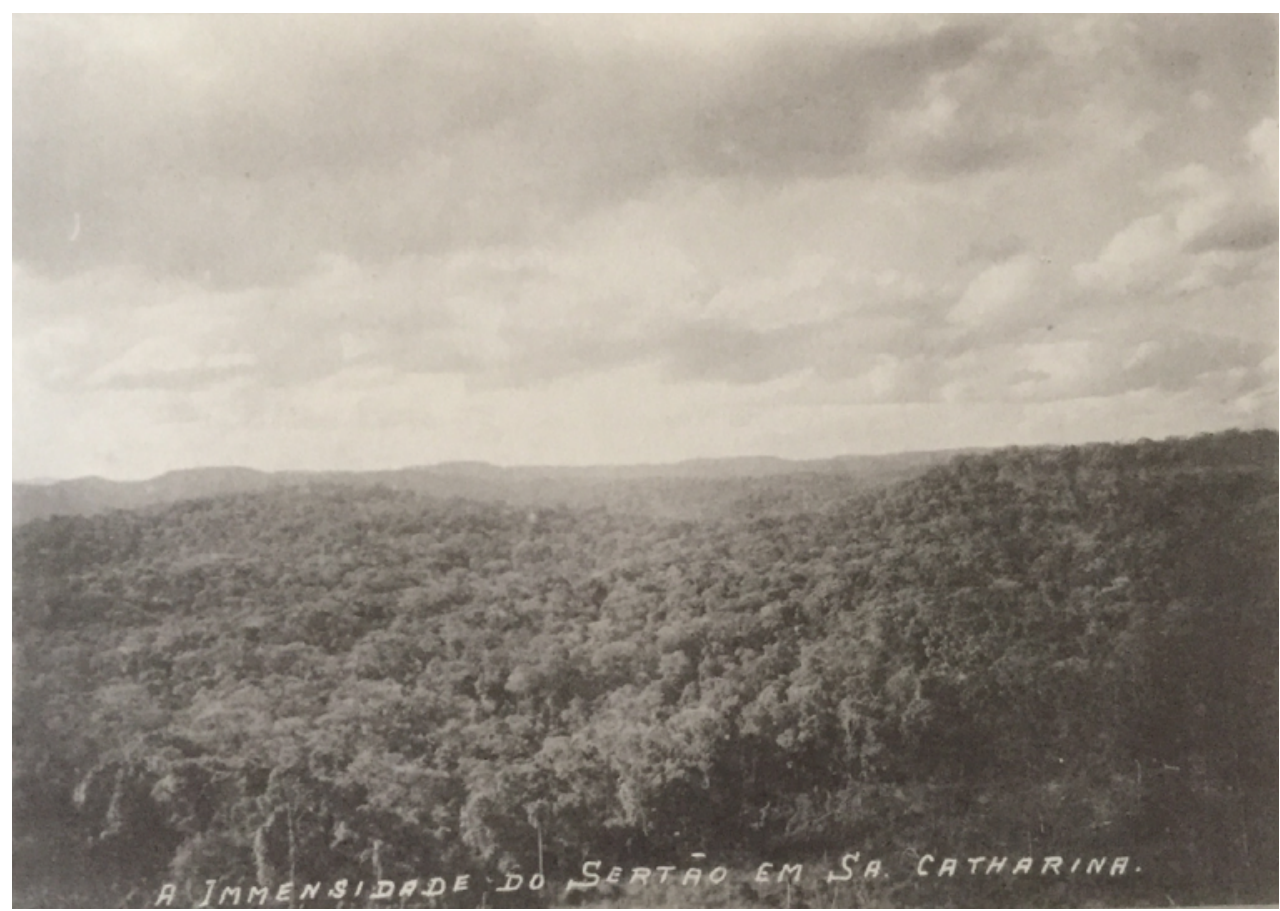

Fonte: Fac-símile do livro A viagem de 1929 (2005).

3.1.

\section{Caboclamento historiográfico}

Por mais que a imagem do sertão catarinense tenha sido fixada como uma paisagem pouco habitada, a moldura criada pelos roteiros de descoberta e conquista revela, ao contrário, um arquivo assombrado e com a presença constante de intrusos. Através da manobra da transferência “[...] como um paradigma sem novidade, portátil, repetível e frequentemente banal [...]" (Taylor, 2013, p.93), o roteiro permite moldar o contexto presente ao ativar o tempo passado. Como um sistema paradigmático de visibilidade, em que o descobridor ou conquistador é 
aquele que vê e controla a cena, além de estar invariavelmente no centro do palco em oposição ao Outro selvagem, garante também o seu inverso, a invisibilidade. A imagem do sertão catarinense não é apenas pintada como vazio demográfico pronto para receber os "os colonos, os immigrantes, os obreiros da civilização" (COSTA, 1929, p.31), a ela também é acrescentada a ideia do caos e da desordem. Em tal caso, faz sentido que o encontro entre Adolpho Konder e Getúlio Vargas, então governador do Rio Grande do Sul, tenha sido o acontecimento mais comentado da viagem de 1929. Muito próximo à Caibi atual, na cidade de Iraí, os dois chefes de estado assinaram um convênio de cooperação mútua entre as forças policiais dos estados vizinhos. Apesar da existência do chamado caudilhismo local, em que coronéis ditavam a "lei do trabuco" acima do poder republicano, o fenômeno do banditismo parece ter cumprido dois objetivos. $\mathrm{O}$ de servir de argumento à implantação da ordem civilizatória e, ao mesmo tempo, manter uma ordem social hierarquizada. Garantida, como já visto, por uma tradição historiográfica reafirmada através do caráter iterativo do arquivo. Afinal, o cenário desolador e assolado pela barbárie apresentado pelo governo estadual da época, aciona diferentes tipos de roteiros, definindo protagonistas e antagonistas.

Assim como os traços dos conquistadores mais remotos são sublinhados no presente, assegurando a reputação dos novos heróis, o mesmo ocorre com as feições dadas ao Outro selvagem através dos roteiros de descoberta. Por mais que o cuidadoso arquivamento do repertório da viagem de 1929 permita visualizar, através das fotografias, a transposição de papéis entre bandeirantes e os homens oficiais da caravana, o mesmo não é possível no caso dos caboclos, retirados por completo das imagens. Ao mesmo tempo, a articulação entre o roteiro e as narrativas produzidas pelos integrantes da comitiva, permite um jogo em que a presença esvaziada dos nativos no primeiro caso (roteiro), é preenchida parcialmente no segundo (texto). Aquilo que o roteiro tira de cena, as narrativas devolvem como uma presença ausente. Na já mencionada alusão de José Boiteux aos dizeres de Gândavo, é possível recuperar o total esvaziamento subjetivo de um grupo indígena específico - os índios Aymorés -, caracterizados pela falta absoluta. Em tempo, essa não é a única associação dos então chamados gentios 
aos caboclos. Costa (1929) transpõe a denominação antigamente reservada aos nativos brasileiros para o seu contexto dizendo: "Tambem agora se fizeram conquistas, se não de terras, pelo menos de populações brasilicas que se estavam desnacionalizando, pelo abandono completo em que viviam, sem a minima ligação com a nossa patria e totalmente alheiadas da communhão nacional.” (s/p, grifo meu). De olho nos roteiros e nas narrativas do arquivo regional, a representação do caboclo é feita pela sobreposição de características familiares ao selvagem brasílico - marcadas pela falta e pela negatividade - e, principalmente, descartando o seu repertório próprio.

Ao recuar à matriz historiográfica nacional, é possível detectar traços fundantes da tipologia do nativo que atravessam o tempo. No manual de Von Martius (1845), a diferenciação entre a figura do colonizador português e do nativo se dá através das famosas perversões da costumes, da moral e da lei. Além disso, sob o olhar dos conquistadores, doravante donos das terras, os nativos são transformados em invasores:

\footnotetext{
Quando os portuguêses descobriram o Brasil, e nele se estabeleceram, acharam os indígenas proporcionalmente em tão diminuto número e profundo aviltamento, que nas suas recém-fundadas colônias podiam desenvolver e estender-se quase sem importar-se dos autóctones. Êstes exerceram sôbre os colonos uma influência negativa tão sòmente, por quanto só os forçaram a acautelar-se contra as suas invasões hostis, e por isso criaram uma instituição singular de defesa, o Sistema de Milícias. (VON MARTIUS, p. 447, grifo meu)
}

Até mesmo a tendenciosa ideia de uma baixa densidade populacional autóctone, presente na citação, cabe ao objetivo da Bandeira Konder de conquistar as terras catarinenses. Em consonância com o trecho mencionado, o relato de Costa (1929) reproduz uma presença escassa e indesejável na paisagem: "Na costa rio grandense é tudo solidão e deserto, lobrigando-se, apenas, de quando em quando, a largos espaços, uma choupana de 'intruso', que ali se abrigou para melhor explorar as mattas, roubando madeiras das terras devolutas." (p.17, grifo meu). Apontando na mesma direção, geográfica e ideologicamente localizada no 
lado oposto às colônias europeias, a suspeita população é notada pelo diário de D’Eça (1992):

\begin{abstract}
Continuo enlevado pela paisagem fluvial que nos ladeia: barrancas altas, onde, de longe em longe, espiando as balsas lentas que descem para S. Thomé, na Argentina, surgem telhados escuros, ou algum fio de fumo assignala uma tennue mancha humana naquellas mattarias vastas e desertas'." (p.24, grifo meu)
\end{abstract}

Em contraste com a margem catarinense, onde a nova paisagem colonial e seus integrantes despontam com riqueza de detalhes - " [...] toda uma gente forte e decidida, disposta ao trabalho, levando áquelles rincões, até há pouco incultos por abandonados, a prosperidade e a riqueza." (BOITEUX, 1931, p.10) - os contornos da população nativa são fugidios, confundem-se com a paisagem. Assim como nos roteiros de conquista os nativos são reconhecidos e, ao mesmo tempo suprimidos. E dessa forma, são transferidos para o espaço das margens, situando a posição central do conquistador. Confundidos entre as matas e os animais no imaginário colonial, alcançam uma espécie de exterioridade decorativa nos textos. Embora estes sinalizem a presença de caboclos ao longo do trajeto da comitiva, a representação feita é frequentemente distante e silenciosa. Do contrário, são idealizadas como as descrições que o escritor D’Eça (1992) faz ao caboclo Areias, um timoneiro que conduz a balsa no posto de almirante fluvial. A representação do corpo do caboclo, aqui, se aproxima em muito à literatura indianista de José de Alencar. O exemplo é oportuno, visto que o projeto literário do autor compartilhava das ideias de Von Martius, as quais permeiam seus romances e suas reflexões sobre a cultural brasileira (SOMMER, 2004, p.181). Em seu pós-escrito de Iracema (1865), o escritor comenta o processo de criação do romance como uma montagem, cujo material de base foram as informações coletadas em relatos dos navegadores europeus, dos quais extraiu personagens e conflitos reais. Ao usar fontes coloniais para a construção ficcional, traz junto um olhar marcado pela exterioridade própria do conceito de "exótico" como “[...] aquilo que não pertence a quem assim o qualifica, com aquilo que não é seu nem participa do seu mundo, aquilo que é radicalmente diferente e que é, sobretudo, 
exterior a quem lhe confere tal designação" (SCHØLLHAMMER, 2007, p.176). É na Carta de Pero Vaz de Caminha ${ }^{27}$ que esse mesmo olhar revela o seu sentido original, o de descrever os gestos do selvagem de acordo com os interesses de apropriação das terras e dos corpos. Não por acaso, a descrição de Areias coincide com a os contornos heróicos de personagens indígenas, os quais desempenhavam aventuras épicas no passado lendário que se estavam construindo no romantismo do século XIX (SÁ, 2012, p.184). Retratados pela força física e plasmados à beleza natural da paisagem nativa, enquadram-se na oposição paradigmática entre Natureza e Cultura. Por um momento, “a voz maviosa, débil como sussurro de colibri [...]" (ALENCAR, s/d, p.43) de Iracema parece manifestar-se no corpo de Areias, pelo traço romântico de D’Eça (1992):

O timoneiro - um caboclo destorcido que se chama Areias - avisou-nos de que dentro de alguns instantes vamos passar a primeira corredeira. [...]

Mas Areias e o companheiro - que antes manobravam com uma grande vara de arrimo - lestos e corajosos pulam n'água e, à força de ombros, num retesamento de músculos que os verga, entumesce-lhes as veias do pescoço e dilata-lhes os olhos, reconduzem a lanchinha ao minúsculo canal entre as pedras; e antes das 'águas fundas', com a agilidade de felinos, sobem à embarcação e, novamente, cada qual retorna aos seus postos, encharcados e satisfeitos da proeza. (D'EÇA, 1992, p. 23-24)

A "mancha humana" avistada pelo escrivão da caravana tem ainda outra camada significante, a da carga negativa que a mestiçagem representava ao ideal racial da nação. Naquele então, era justamente através da raça que a nação era entendida. "Por meio dela se explicavam sucessos políticos, fracassos econômicos ou hierarquias sociais assentadas." (SCHWARCS, 1993, p.307). Preservar o futuro racial do Brasil, sua unidade nacional e sua homogeneização foram preocupações dos eugenistas ao longo da década de 1920 (DIWAN, 2018, p. 118 $)^{28}$. É certo que a passagem para 1930 promete uma mudança paradigmática com a troca de abordagens biológicas por outras, em termos culturais. Ao mesmo

\footnotetext{
27 CASTRO, Sílvio. A carta de Pero Vaz de Caminha. Porto Alegre: L\&PM, 2017.160p.

28 DIWAN, Pietra. Raça pura: uma história da eugenia no Brasil e no mundo. $2^{\mathrm{a}}$ ed. São Paulo: Contexto, 2018.
} 
tempo, em 1929, Miguel Couto - Presidente da Academia Nacional de Medicina ainda defendia a tese de que a mistura racial levaria à degeneração nacional, no Primeiro Congresso Nacional de Medicina. Contudo, na esteira do nacionalismo antecipado pela viagem de 1929, a mestiçagem seria reposicionada como símbolo da brasilidade. E neste intervalo, vivido pela caravana de Konder, os caboclos aparecem ora como invasores do sertão, ora como representantes ideais da alma brasileira.

A mudança do status do mestiço brasileiro - o caboclo - já vinha sinalizando a mudança de percepção sobre o povo nacional. Personificado no personagem de Monteiro Lobado, o também caboclo Jeca-Tatu, passará de inferior e inapto à vítima de um governo irresponsável. A cura da população sertaneja seria, por fim, a cura do país, regenerado através de políticas higienistas. (p.102). E não mais pela radical via da eugenia, interessada em extirpar os indesejáveis do corpo social da nação ${ }^{29}$. A este respeito, o episódio em que a caravana de Konder consegue abrigo em um barbaquá abandonado - morada provisória dos caboclos para a extração de erva-mate - é bastante expressivo. "O ambiente era o mais apavorante, desconfortável e antihygienico possivel." (p.60), diz Costa (1929). O que segue da experiência relatada é ainda mais sintomático, quando visto pela lente de um discurso de associação entre doença e mestiçagem. No meio da noite, uma chuva torrencial inunda a precária construção de taquaras e teto de palha. Em meio às trovoadas, um caboclo bate à porta para pedir auxílio médico à comitiva do governador. Quem sai em socorro do familiar do nativo não é o médico, senão o laureado homem de letras da comitiva, Othon Gama D’Eça.

Naquele então, não somente a suposta falta de perfectibilidade era correlacionada à raça, mas também à criminalidade. Apoiado nessa tese, outro roteiro é colocado sobre a paisagem do sertão catarinense pelo olhar dos

\footnotetext{
29 É importante destacar a co-existência de ambas abordagens dentro do amplo espectro do movimento eugenista. E cabe ainda relatar a coincidência do comentário do jornalista e militante integralista Gustavo Barroso sobre o lançamento do livro de Renato Kehl - ícone da eugenia brasileira -, intitulado Lições de eugenia, no exato ano de 1929. A citação é feita por Diwan (2018): "Barroso escreveu no jornal A Ordem que nenhum país necessitava tanto melhorar sua raça quanto o Brasil. Para ele, com 'a cruzada pró-melhoramento' que o 'bandeirante' Renato Kehl vinha empreendendo com a divulgação da eugenia, os brasileiros passavam a se interessar 'pelos problemas vitais de toda a ordem', sobretudo o problema do melhoramento da nacionalidade" ( $p$. 120 , grifo meu).
} 
bandeirantes. "Um dos grandes flagellos do Oeste catarinense, como o do Nordeste brasileiro, é o banditismo do sertão.” (COSTA, 1929, p.53). A comparação da Guerra de Canudos (1896-1897) se encaixa ao contexto do Oeste catarinense na medida em que este território havia sido resultado da Guerra do Contestado (1912-1916). Desencadeada pela construção de uma ferrovia que ligaria o Centro do país ao Sul, a longa rebelião ${ }^{30}$ foi liderada pelos caboclos da região, expulsos das terras concedidas à empreiteira estrangeira. Dentre as afinidades com a Guerra de Canudos - como o fato de haver se tornado questão nacional ao mobilizar mais de um terço do exército brasileiro - a correspondência entre o sertanejo e o caboclo é a mais importante. Associados aos inimigos anteriores, também considerados fanáticos religiosos, criminosos e ignorantes, contrapõem-se automaticamente ao poder republicano representado pelo líder bandeirante. Quem, também, é intitulado juiz de paz para resolver conflitos entre caboclos no sertão abandonado. A partir do caso de disputa entre as famílias Lara e Cabral, exemplificam-se casos de mortes por terras e ilustra-se o território sem lei que precisa ser urgentemente controlado ${ }^{31}$. Além do enredo de crueldades, Costa (1929) inclui na sua descrição o túmulo à beira da estrada onde foram enterrados pai e filhos assassinados. A viúva recebe ajuda do governador com a abertura de inquérito sobre o crime. As inúmeras cruzes que são vistas pelo caminho ressuscitam muito mais do que vítimas do caudilhismo, também despertam os fantasmas de caboclos insubordinados que continuavam a habitar as terras do Ex-Contestado, convertida em Nova Canaã depois de controlado o conflito. Além dos espectros comunistas 32 que rondam a nação brasileira desde

$30 \mathrm{O}$ trabalho de Delmir José Valentini, Da cidade santa à corte celeste: memórias de sertanejos e a Guerra do Contestado (2016), faz uma releitura sobre o episódio a partir do confronto entre testemunhos da população cabocla e narrativas oficiais.

VALENTINI, Delmir José. Da cidade santa à corte celeste: memórias de sertanejos e a Guerra do Contestado. $4^{\mathrm{a}}$ ed. Chapecó: Argos, 2016. 256p.

31 Nesse sentido, o estudo de Délcio Marquetti, intitulado Bandidos, forasteiros e intrusos: história do crime no oeste catarinense na primeira metade do século XX (2008) recorre aos processos-crime da época para demonstrar como o Código Penal 1890 incriminou indígenas e caboclos. No cerne da diferenciação entre a população local e os imigrantes, está a noção de raça propalada pela Antropologia, Biologia e Sociologia Criminal.

MARQUETTI, Délcio. Bandidos, forasteiros e intrusos: história do crime no oeste catarinense na primeira metade do século XX. Chapecó: Argos, 2008.

32 Por mais que os colonos imigrantes não carregassem o estigma preconceituoso do mestiço, representavam um risco pela proximidade com o comunismo. (DIWAN, 2018, p.117) 
1922 e que são constantemente relembrados pela caravana, através dos vestígios deixados pela Coluna Prestes no caminho. Os comunistas deixam mortes e rastros de rebeldia pelo sertão, indicados por outras cruzes que beiram as picadas, marcadas pela amarração de panos vermelhos. Na medida em que a caravana dos bandeirantes avança heroicamente no cenário de caos e barbárie, o poder soberano se impõe, encarnado pelo chefe de estado. Ao cravar a bandeira nas terras do sertão, decreta a nova ordem, demarca a territorialidade e batiza o povo com o sentimento nacional, cuja “alma verde” metaforizada na retórica de D’Eça (1929) ressoa no nome indígena Caibi:

\begin{abstract}
Senti, hoje, pela primeira vez, a emoção enternecida de ver, da terra estrangeira, a bandeira da Pátria! [...] E daquele solo amigo - onde uma vez tremulara ao lado do pavilhão azul e branco, irmanada por um ideal de Justiça e de Liberdade Humanas - eu pedi a Deus para que sempre nos conservasse unidos à sua sombra maternal e a mantivesse sempre assim no alto, nobre, magnífica, hospitaleira - como a própria alma verde e oiro do meu Brasil. (p.106, grifo meu)
\end{abstract}

Os caboclos, herdeiros de outro forte traço atribuído aos indígenas pelos roteiros coloniais - o de não falantes - têm seu modo de vida e sua cultura interpretados pela perspectiva positivista dos homens do governo nos momentos em que ganham voz. Contada aos leitores de jornal da capital, e ao leitores do livro de Gama D’Eça, a “sabedoria popular” da população local é apresentada sempre com ressalvas ao bom senso e muita ironia, de acordo com o modelo de pensamento racional e cientificista. Em referência aos saberes da população nativa, o manual de Von Martius (1845) já advertia: "Um historiador filósofo, familiarizado com tôdas as direções dêsses mitos populares, de certo não os desprezará; mas há de dar-lhes a importância particular que merecem; - dêle concluirá para várias conjeturas na vida do povo, e há-de pô-los em relação com a essência do grau de civilização intelectual em geral" (p. 453). O cumprimento dessa antiga diretriz comparece não somente no esvaziamento do repertório da população cabocla, traduzido de forma redutora e estigmatizante pelos escrivãos e, assim, confinados no arquivo. Além do modo de pensar, também a expressão oral do caboclo é isolada em relação à norma culta, a julgar pelo emprego 
constante de aspas: “Cerração baixa, sol que racha' é a sabedoria do povo" (p.28), arremeda o escritor D’Eça (1929).

Dentre todos os registros da viagem de 1929, apenas o diário de Othon Gama D’Eça se refere à população autóctone. Todavia, suas impressões se somam às fantasias dos colonos através dos vestígios e das ruínas desses povos. Os estudos arqueológicos ${ }^{33}$ da região são capazes de resgatar a presença indígena a até onze mil anos atrás, considerando o caráter nômade das diferentes etnias. Entre elas estiveram os Guaranis, os Xokleng e os Kaigang. Com a chegada dos colonos imigrantes, muitos vestígios eram encontrados. Urnas funerárias engatavam no arado da terra, pontas de flechas assomavam à beira do rio Uruguai, trilhas antigas e os chamados "buracos de bugre" 34 apareciam nas áreas próximas aos loteamentos. Embora não seja comum ouvir relatos dos colonos de Caibi sobre a presença física dos índios, é certo que povoavam e povoam o seu imaginário: "Todos esses elementos suscitavam curiosidade nos novos povoados e os faziam suspeitar que, antes deles, o território deveria ter sido ocupado." (SCHMITZ, 2011, p. 74).

Durante a já mencionada visita ao escritório da Companhia Territorial Sul Brasil, o escrivão da caravana repara no interior da residência: "Vi alguns vasos curiosos da mais velha cerâmica indígena e vários quadros a óleo com assinaturas de valor." (D'EÇA, 1929, p. 47, grifo meu). Ao percorrer as margens do rio Uruguai pela manhã, descreve uma atmosfera carregada de mistério na barranca do rio: "Há um trecho, porém, beirando umas rochas a pique, cilíndricas e polidas como se fossem colunas de um templo indígena; e umas pedras de feitios esquisitos, que pareciam crescer dentro da neblina fumarenta que apagava a paisagem em torno.” (p.22). Na primeira noite em meio à mata, o escritor tem uma visão. Da porta da barraca onde observa os caboclos em torno da fogueira, as feições indígenas de seus rostos inspiram-lhe uma imagem fantasmagórica da

$33 \mathrm{O}$ conjunto de estudos compilados em Antes do Oeste Catarinense: arqueologia dos povos indigenas (2011), organizado por Mirian Carbonera e Pedro Schmitz, recupera as histórias dos povos que viveram nas matas e nas várzeas dos rios antes da chegada dos colonizadores europeus e dos seus descendentes.

CARBONERA, Mirian. SCHMITZ, Pedro Ignacio (Orgs.). Antes do oeste catarinense: arqueologia dos povos indígenas. Chapecó: Argos, 2011.364p.

34 Grandes depressões de terra que serviam de moradia subterrânea aos Kaigang. 
floresta, sutilmente associada à presença indígena: "A chama clara e alta iluminalhes os rostos, sobe coroada por um cocar de fumo e risca no chão sombras agudas e vacilantes. Para lá do fogo é a treva absoluta, misteriosa e imponderável [...]” (p. 69). Sob o ponto de vista do homem de letras, segundo Derrida (1994, p. 27), os espectros não falam. Essa condição inominável, impalpável, avessa a todo o saber, retorna continuamente, sempre em silêncio, desafiando os registros do escrivão oficial 35 .

À exceção de uma única aparição isolada, os indígenas só retornam aos registros da viagem de 1929 na condição de espectros indecifráveis. Nos últimos dias da expedição, o presidente Konder recebe uma delegação de índios coroados36. O “Capitão”, assim descrito ironicamente por D’Eça (1992), mostra um ofício do Ministério da Agricultura que comprova a posse de uma terra já vendida à terceiros. A resolução do governador catarinense, ao visitar o pequeno acampamento, é imediata: providencia-lhes instrumentos agrários e abre uma escola, a Escola José de Anchieta. Para contornar a inconveniente irrupção no cenário, no entanto, a medida mais eficaz é o acionamento da tradição literária. Através desta, nega-lhes o presente e os devolve às sombras do arquivo: “Perguntei ao ‘capitão' se estava agora mais satisfeito. - Estou-se! - respondeume num sorriso inexpressivo, quase bestial, mostrando umas gengivas roxas e sem dentes. Pobre Alencar! Como são esses bugres diferentes dos teus Peris e das tuas Iracemas! (p. 144).

O capítulo seguinte propõe uma experimentação narrativa imantada pelas proposições de Silviano Santiago e Luiz Antonio Simas sobre o mestiço e o caboclo. O romance e o caderno de notas que seguem tentam ampliar dos limites da história de fundação da cidade a partir do método materialista de leitura, de

\footnotetext{
${ }^{35}$ Nos termos de Shakespere, em Hamlet, citados e trabalhados por Derrida (1994), Othon Gama D'Eça seria o chamado scholar, o erudito, intelectual instruído, homem de cultura - identificado pelo teórico no personagem cético de Horácio que, em Hamlet, é convocado pelo Príncipe para fazer falar o fantasma do pai. A tentativa é inútil: "Nunca houve um scholar que, enquanto tal, não acreditasse na distinção definitiva entre o real e o não-real, efetivo e o não-efetivo, o vivo e o nãovivo, o ser e o não-ser [...], a oposição entre o que está presente e o que não está, por exemplo sob forma de objetividade." (DERRIDA, 1994, p.27)

36 Trata-se de um termo criado pelos portugueses em referência ao uso de plumas na cabeça e ao corte de cabelo ao estilo franciscano. A classificação também é aplicada a Kaigangs de outros estados, bem como outras etnias. Segundo o registro de D'Eça, o grupo vinha da cidade de Xanxerê (SC).
} 
Walter Benjamin, e da escrita em transe. Nas próximas páginas, romance e caderno de notas alternam-se. O texto ficcional transcorre nos anos de 1929 e 1992, ambientados na antiga colônia e na cidade, respectivamente. Enquanto o caderno de notas reconstitui a experiência da pesquisa de campo na cidade, especulando formas de narrar no próprio ato da escrita.

Para dar o próximo passo neste trabalho que cruza o saber das macumbas e o conhecimento científico, cabe a invocação ao estilo das religiões afro-indígenas, que resgatam a memória popular através das histórias dos guias e dos pontos cantados (CONCONE, 2011, p.289). Canta um ponto que caboclo é aquele que "[...] não tem caminho pra caminhar, caminha por cima da folha, por baixo da folha, em todo lugar" 37 .

\footnotetext{
37 Disponível em: <https://www.youtube.com/watch?

$\mathrm{v}=$ CoxjVFfvI7g\&list=RDCoxjVFfvI7g\&start_radio=1> Acesso em: 17 mar. 2021.
} 
4

\section{O baile da onça}

\section{- romance com notas}

Nota inicial

[O desfile]

I

29 A pegada larga

92 A tosse de terra

Nota I

2

29 A chegada na colônia nova

92 A cabana da onça

Nota 2

3

29 Os bichos do terreiro

92 A gaveta de Morena

Nota 3

4

29 A reunião dos colonos

$92 \mathrm{O}$ esconderijo do bicho de pé

Nota 4 
5

29 Um intruso no milharal

$92 \mathrm{O}$ colchão de folhas

Nota 5

6

29 Catinga de onça

92 Carta aos moradores

Nota 6

7

$29 \mathrm{Um}$ bandeirantes pede abrigo

92 Bucho de terra

Nota 7

8

29 O bandeirante é um escritor

$92 \mathrm{O}$ baile da onça pintada

Nota 8

9

29 O sonho do escritor

92 A onça na jaula

Nota 9

IO

29 Um índio chamado Vitorino

92 A barriga de Mãe Clara 
Nota 10

II

29 O baile da colônia

$92 \mathrm{O}$ mijo da onça

Nota II

I2

29 O rabo da onça

$92 \mathrm{O}$ rabinho escondido

Nota 12

I3

29 Ao jornal República

92 Emboscada para os bandeirantes

Nota I3

I4

29 O mapa da colônia

$92 \mathrm{O}$ último sonho de Vitorino

Nota I4

I5

29 Folhas verdes

92 A última migalha

Nota 15

[O desfile $]$

Nota Final 


\section{Nota Inicial}

A ideia de retornar a minha cidade origem não fazia parte dos planos desta pesquisa. Pelo menos não como uma escolha consciente. Até então minha relação com a terra onde nasci e passei os 6 primeiros anos da infância era de aversão. Lembro de uma fantasia que se repetia na minha infância. Ela vinha do mesmo costume contado por Walter Benjamin, ainda menino, em ficar meio passo atrás nas caminhadas com a mãe pelas calçadas de Berlim. Para além do fascínio que ele dizia sentir pela prostituta da cidade, lembro de fantasiar como seria estar na pele dela. Não tanto por ser uma mulher, mas por ser a única, como veem os olhos do menino antigo de Drummond. Única figura que manifesta o desejo publicamente e que, por conta disto, vive no limiar da cidade, em uma geografia proibida, na rua de Baixo onde é proibido passar. Foi por conta daquilo que nem eu sabia até os 6 nos de idade - aquilo que nem o menino sabe, diz o poema, e quer saber, querendo a puta que a cidade se tornou uma fronteira. Em que eu ficava meio passo atrás, olhando de onge os nomes públicos da minha família, que fizeram sucessão na prefeitura. Sempre antasiando como seria renunciar a um nome e à história que vem junto com ele.

Uando o rumo da pesquisa apontou para o retorno à cidade natal, quis me convencer que trabalho poderia ser feito à distância. Cheguei a ficar contrariado quando minha antiga rientadora sugeriu que passasse algum tempo por lá. Feitas as pazes com o surgimento lesse desejo paradoxal, submeti um projeto de pesquisa de campo ao programa PROCAD, que promove interações científico-acadêmicas entre diferentes estados. Eu ficaria três meses na cidade de Chapecó, a Ioo quilômetros de Caibi. Elaborei um roteiro em que reservava maior parte do tempo para visitas em arquivos regionais e pesquisas na biblioteca da universidade que me receberia. Ao final, foram os caboclos que me levaram até a cidade que eu tanto evitava. Como tema central desta investigação, tive que abrir um espaço no roteiro para entrevistá-los pessoalmente, colocando os pés finalmente nas calçadas de menino. Resisti até o último mês da viagem, quando finalmente passei uma semana inteira percorrendo o bairro dos caboclos em busca de suas narrativas sobre a fundação da cidade, enquanto me hospedava na própria casa da infância.

Em uma única busca no site da Unochapecó encontrei o currículo da professora ideal para me ajudar. Arlene Renk é uma pesquisadora catarinense que dedicou parte da trajetória 
acadêmica ao estudo sobre os caboclos. Estes que se apresentaram para mim na roda do bailado como entidades espirituais e que, neste outro contexto, se referem a um grupo social específico, os habitantes nativos da região em que a cidade colonial foi fundada. A contribuição de Arlene seria enorme, já que o seu trabalho dava contornos para a relação entre caboclos e colonos que eu tentava elaborar a partir dos insights da experiência do transe místico. O estudo intitulado A luta da erva: um ofício étnico da nação brasileira no oeste catarinense (2006) aprofunda a condição dos caboclos de cidades vizinhas à Caibi durante a ocupação das terras catarinense pelos colonos descendentes de europeus, no início do século XX. O trabalho abriu um ponto de vista historiográfico a respeito desse grupo ainda tão desconhecido para mim e permitiu vislumbrar inúmeros pontos em comum com a história de fundação de Caibi. Da qual só tinha acesso à versão protagonizada pelos colonos, além das memórias de família. Essa pesquisadora, até então desconhecida, havia defendido a dissertação sobre os caboclos no programa de Antropologia Social da Jniversidade Federal do Rio de Janeiro. Portanto, era como se eu e Arlene fizéssemos o hesmo trânsito entre capital e interior em tempos diferentes. Ambos descendentes de olonos, atravessados pelo interesse nessa outra forma de vida dos caboclos. Esta seria ma entre tantas coincidências que abririam a experiência de campo que relato aqui, neste aderno de notas, como uma prática de terreiro - nos dizeres do filósofo das macumbas, uiz Antonio Simas. Ou seja, um transbordamento daquele espaço restrito da roda do ailado, como espaço exclusivo das expressões de culto religioso, para a abertura de uma imensão imaterial, espaço de invenção e leitura da história de fundação a partir de outra ota. Guiada pelas semelhanças, analogias e correspondências mágicas que permitem criar uma experiência do presente com o passado. E que sugerem uma nova forma de narratividade na reconstituição da experiência. 


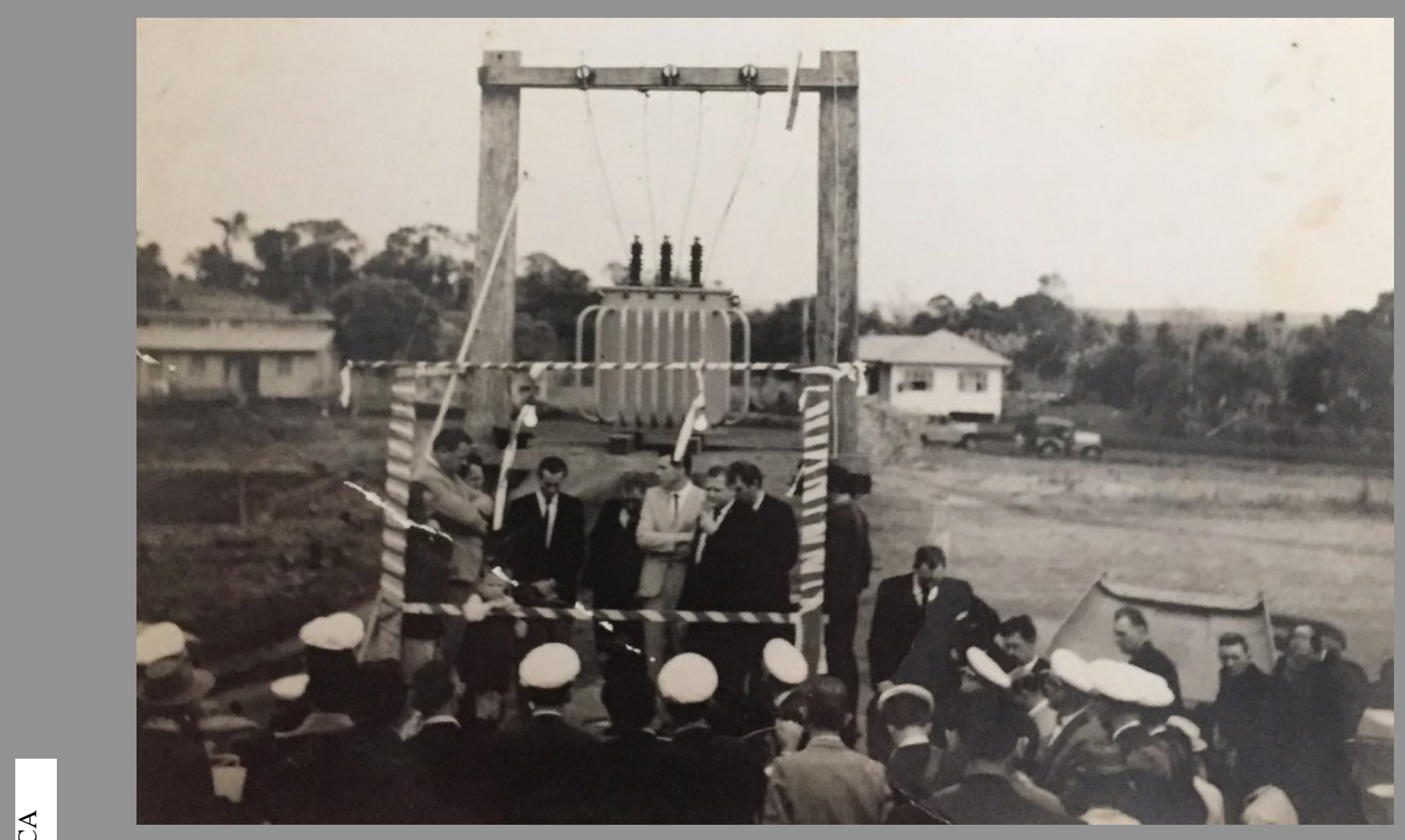

Figura 7 - Fotografia do avô materno, prefeito de Caibi de I6/II/1965 a 30/OI/1970

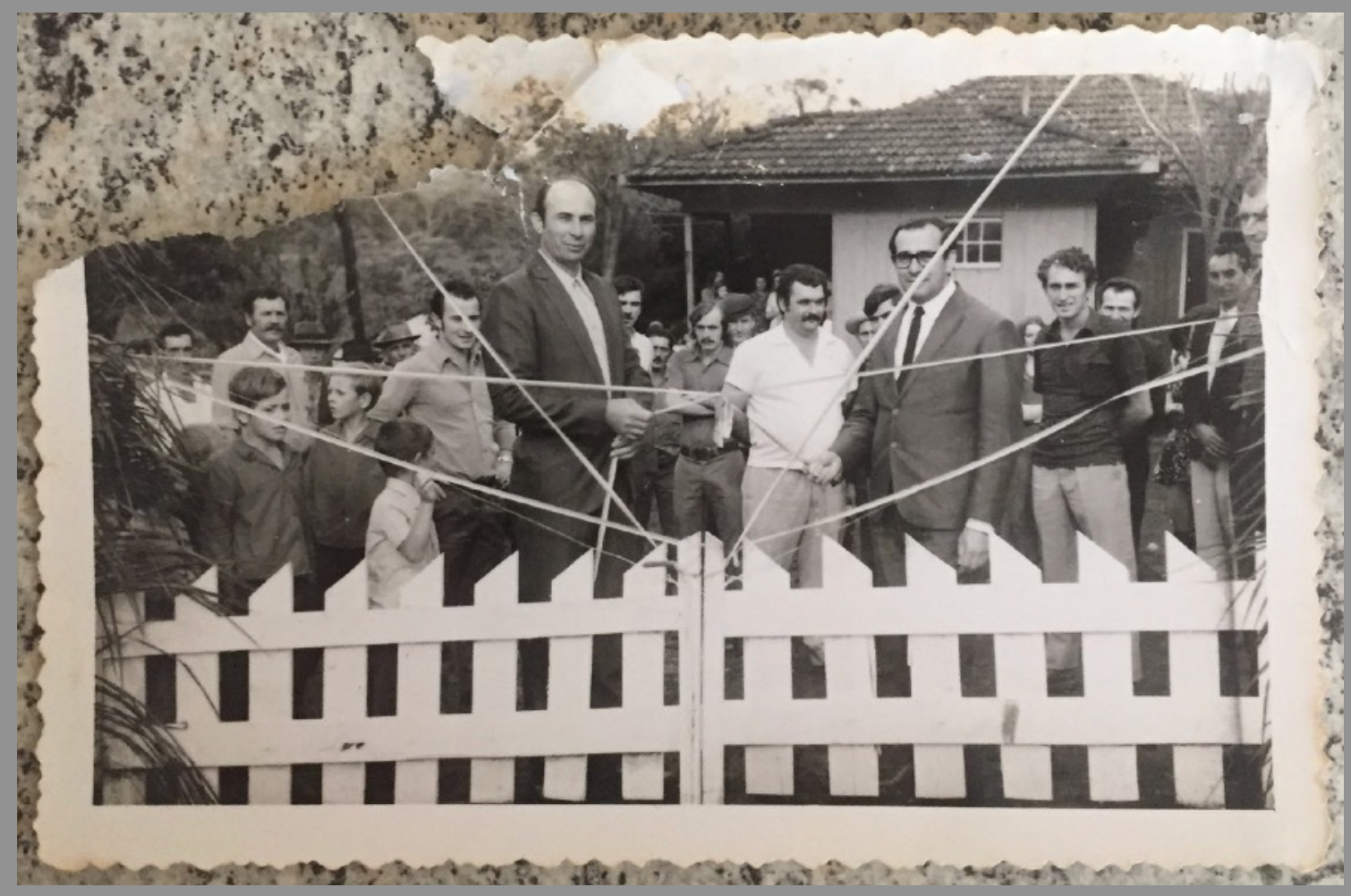

Figura 8 - Fotografia do avô paterno, prefeito de Caibi de 3I/oI/I970 a 3I/oI/1973 


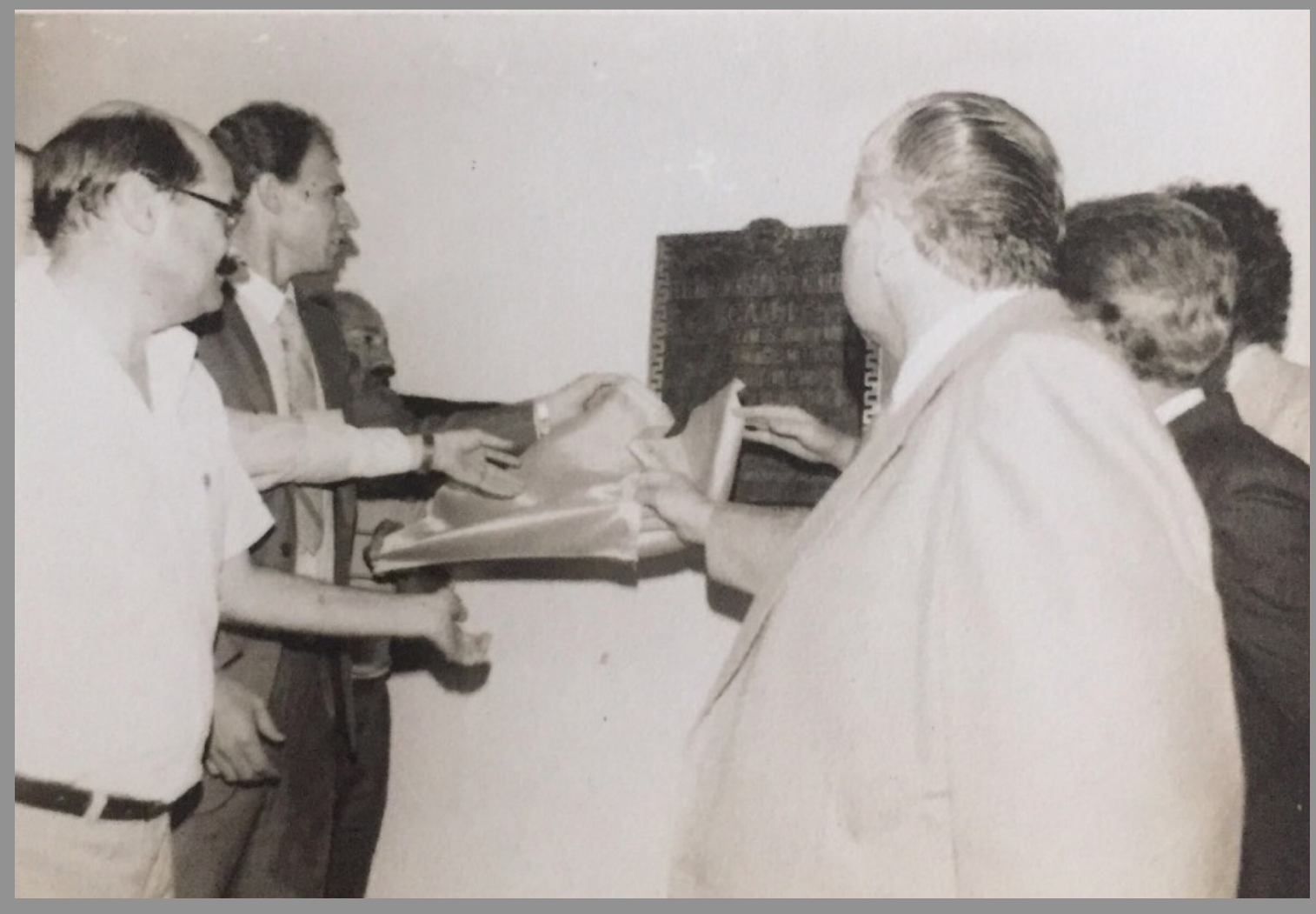

Figura 9 - Fotografia do pai, prefeito de Caibi de oI/O2/I9 83 a 3I/I2/I988 


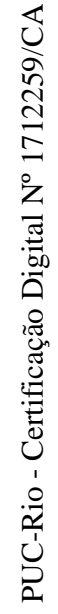

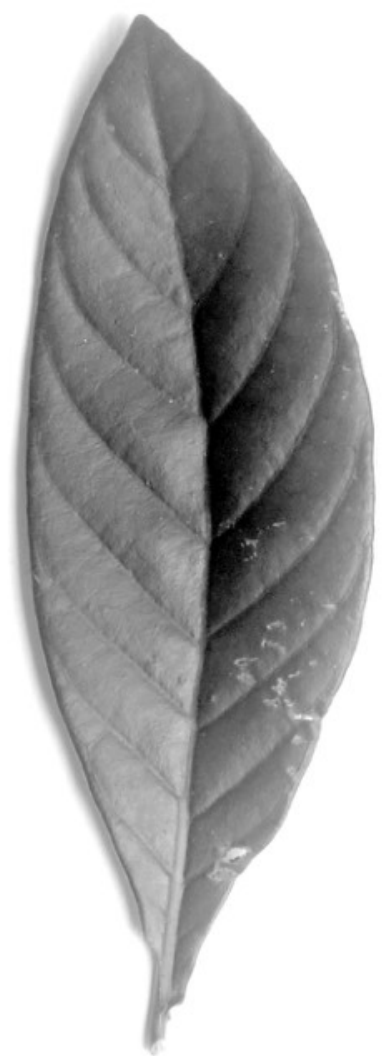




\section{O desfile}

A nuvem de maritacas voou sobre a cabeça de todos moradores que estavam na praça da cidade

O carro alegórico estacionado no meio da rua do progresso aguardava o tiro da pistola pra avançar Em cima da carroceria do caminhão enfeitado com palmeiras de verdade os nossos heróis os bandeirantes fantasiados com chapéus e carabinas no ombro sentaram no tablado de madeira

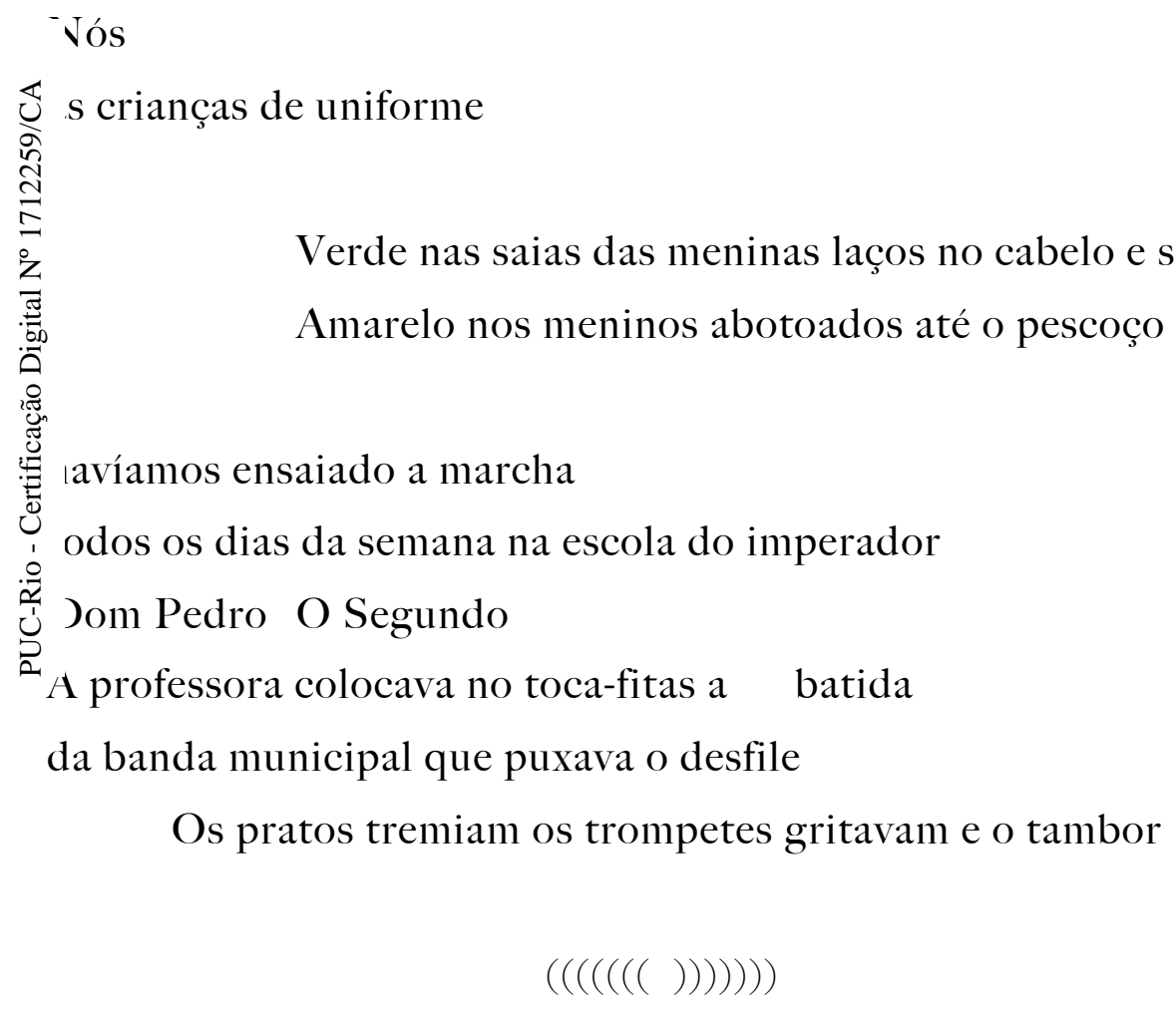

batia como um coração embaixo

da terra fazendo o joelho levantar

de um jeito automático antes de pisar forte no chão 
A marcha era reto e pra frente

porque logo atrás da gente

vinham os ginasiais depois

os mais-velhos e os ex-combatentes da Guerra

Olhei pra Camarada Espingarda que estava com os olhos

ardidos

e a cabeça baixa olhando os cadarços

desfeitos

iguais ao nosso plano secreto

$\mathrm{Na}$ frente

em destaque a rainha da cidade segurava a bandeira

nacional com seu vestido

verde e o penteado armado

Uma montanha de fios

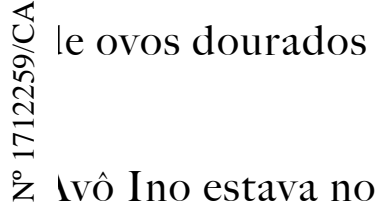

ravado no peito

Ao lado o prefeito se preparava pra dar o tiro

da arrancada

a pistola apontada pro alto

fuando a rainha deu um grito

E logo em seguida tapou a boca

com a mão de luvas compridas

Todos olharam

para o bando de índios pintados

alguns de bonés outros cocar

penas de papagaios nos braços

enxadas machados e foices pra cima 
Surgiram na esquina contrária dos bandeirantes

pela rua Getúlio Vargas em fila

embalada cantando um canto

sem palavras conhecidas

Mas que marcavam cada pisada

forte estalando os pés no asfalto

Como se além dos chocalhos nos tornozelos

tivessem um tambor

escondido no corpo

$$
\begin{aligned}
& \text { pisada forte } \\
& ((((((())))))) \\
& \text { pisada fraca } \\
& \text { pisada forte } \\
& ((((((())))))) \\
& \text { pisada fraca } \\
& \text { pisada forte } \\
& ((((((())))))) \\
& \text { pisada fraca }
\end{aligned}
$$

Os passos lentos e rápidos dos índios paramentados

pendendo sempre pra um dos lados

passou na frente da nossa marcha

parada no tempo

Os instrumentos de sementes

faziam barulho de cobra e eram muito mais coloridos

do que os nossos uniformes verdes

e amarelos 
O índio-chefe que puxava a fila

vestia uma pele de onça nos ombros

A boca do bicho

morto cobria a cabeça dele

e as pintas malhadas desciam pelas costas

quase

encostando no chão

Ele entrou pela calçada da praça

e a fila de índios seguiu as pisadas fortes

e fracas sobre o tapete de flores

estendido para os bandeirantes

Os olhares congelados de cima

do coreto seguiam o chefe-onça até o canteiro

entral onde ficava a estátua do fundador

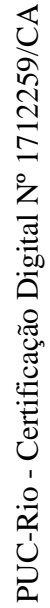

da cidade

I fila indiana que

azia uma cobra grande foi cercando o pedestal

formando círculos cada vez maiores até

preencher todo o gramado

iobre o rio de cocares e penas de pássaros

continuava em pé a estátua

de fraque com gravata borboleta

e a mão de ferro escuro estendida pro alto

com o ramo de folhas

verdes empunhadas 

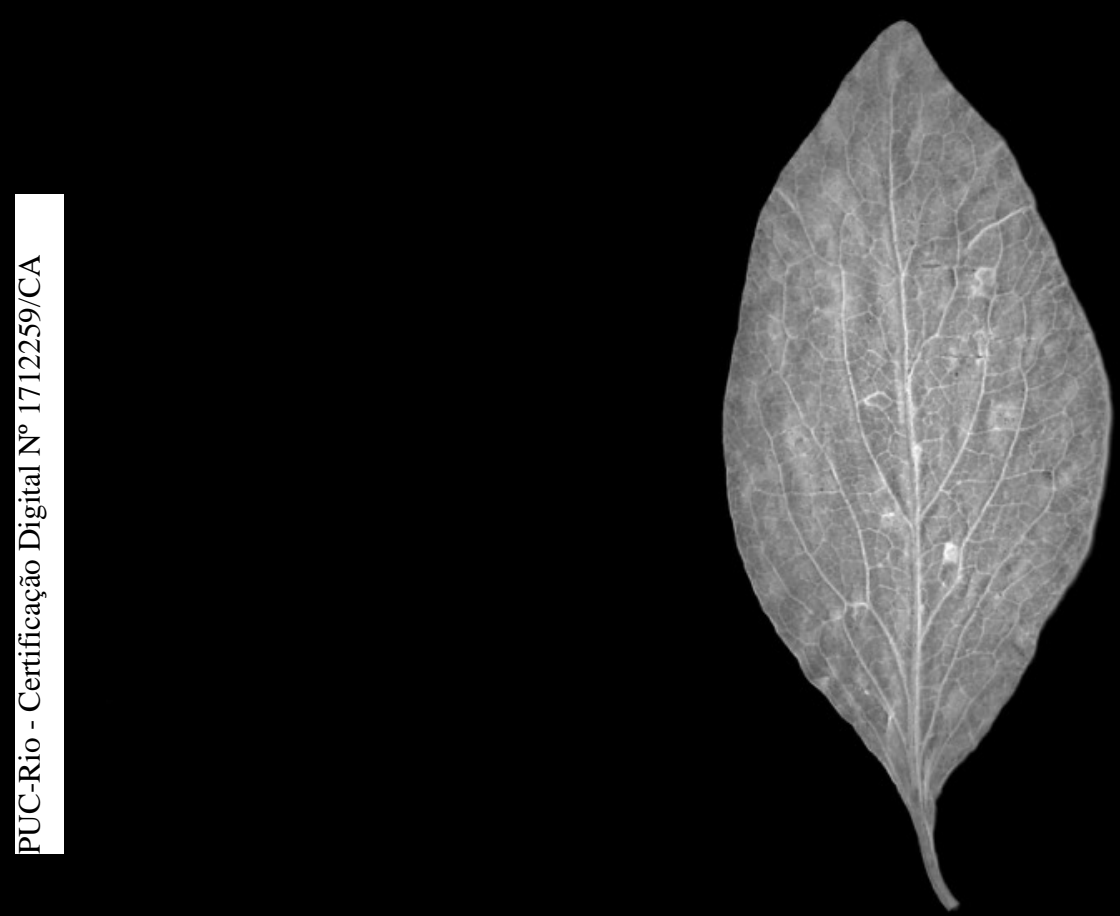

- I - 


\section{I.29 A pegada larga}

Fazia dias que Vitorino não saía de carabina

deitada no ombro para vigiar a fronteira

fechada de mato bravo na beirada

da colônia

Até ouvir um colono dos lotes de cima da sede

no armazém do Senhor Klein

reclamar da reunião dos moradores no dia seguinte

com o sotaque alemão

abrasileirado

itorino pegou a picada para os lotes de baixo

castigando o cavalo

s sacas de farinha pulando

a trilha cheia de pedregulhos

Do milharal

mulher o viu largar o cavalo em frente de casa

em descarregar as sacas

seguir para vigília

Sozinha tirando a espigas

com a barriga redonda

Alma descontava a raiva do marido

nos mosquitos mortos à tapa 
Vitorino colocou a arma

no ombro e pegou o riacho que passava

perto da casa

foi seguindo na

direção da água a

correnteza era

fina

uma

cobrinha

verde

entortando o

rabo para o mato fechado

O homem sempre ao lado do murmúrio

orrente lembrando dos queixumes de Alma

Ss ouvidos confundidos pelos pios de pássaros

esconhecidos enquanto o guardião

visava com um assobio curto e outro comprido

os bichos da floresta

que outro bicho

haior e desconhecido estava à caminho

riozinho já ia perdendo a força

engasgando nas pedras quando mais adiante

a clareira que invadia as sombras verdes da mata

apareceu

Os raios de luz penetravam nos braços das árvores

Aquele fiapo de rio tomava fôlego

e formava uma enseada

Neste ponto onde o rio engravidava

o olho da fonte brotava água

sem parar 
Quando o colono se ajoelhou

com a mão pronta para molhar o rosto

bateu o olho na pegada larga

que já conhecia

[marcada no barro]

Vitorino levantou num salto

e uma revoada de maritacas saiu veloz

e louca da copa da árvore

Depenados os galhos

onde estavam escondidas as aves

a nuvem verde barulhenta desapareceu no céu

O colono deu passos largos para trás

tirando o corpo daquele tamanho

do meio do descampado

e começou a contornar a margem do pequeno lago de longe

entre os arbustos

O cano da carabina

apontava para cada ruído

pequeno que saía detrás das folhas

Os passos atrapalhados estalavam

gravetos e folhas secas

Sorte a dele

era o único bicho grande

presente naquele momento

Um pouco mais distante da margem

a cabana de taquaras estava vazia

porta e janela sempre abertas

deixando o ar passar 
O roçado abandonado era puro mato crescido

O teto de palha dançava com o assobio

do vento

enquanto aquele bicho invasor

voltara a rondar por aquelas bandas

tirando o sono do colono 


\section{I.92 A tosse de terra}

No dia depois do desfile

a cozinha cheirava igual aos velórios da casa mortuária

Da cabeceira da mesa de canela velha

Avô Ino esticava as costas encurtadas

para enxergar o terreiro lá fora

Não era o galinheiro

nem o Casemiro metido no meio dos canteiros

arrancando o capim que invadia a horta

que o avô vigiava

Era pro muro alto

os fundos do terreno

年

onde ficava a minha cabana

atrás do poço seco que assobiava

[ue Avô Ino olhava

¿u aproveitava pra pegar

as sementes do melão

com pele de sapo

jue sobravam no prato

dele

As modas de viola e acordeom

chorado da Rádio Tupi não ajudavam Vó Alma

que estava com aquela cara de domingo chuvoso

armada

depois que o avô mandou ela engolir o choro 
Encolhida na cadeira

ao lado do fogão de ferro

ela esticava os dedos de graveto torto

de tanto debulhar milho

no calor do fogo

e as migalhas caíam no chão

A leiteira esquentava na chapa quente

A apresentadora da Hora Italiana se despediu

dos colonos antigos que ouviam o programa

e Avô Ino girou o corpo duro

igual um parafuso enferrujado

na cadeira

pra ouvir o locutor

告

I O grupo de índios que vivia na área de um hectare próximo ao parque florestal invadiu a idade no dia de ontem durante o desfile anual de fundação da cidade O líder do grupo presentou um documento segundo ele aprovado pelo Ministério da Justiça que dá direito uma área de 275 hectares A faixa de terras contestada foi considerada território radicional e inclui além de um trecho de preservação ambiental a fonte de águas termais Lo balneário e cerca de 40 propriedades de moradores do bairro vizinho Em entrevista o acique e seu vice afirmaram que a ofensiva se deve ao esgotamento do prazo dado a Funai iara a realização da demarcação |||

Morena saiu do quarto de Mãe Clara

com o prato de polenta

vazio

e fechou a porta pro bebê

cochilar em paz

na barriga 
Pai Vitório apostava

que o próximo menino

ia dar tão certo

que sairia de dentro

de Mãe Clara

maior que eu

Morena passava

olhando tudo de dentro dos olhos

rasgados

O pano de prato no ombro

disfarçado e o rabo de cavalo

escorrido até a cintura

balançando

II O prefeito de Folhas Verdes disse ter sido pego de surpresa pela Funai com quem vinha 仓ั

egociando uma saída civilizada para a situação desde o ano passado Pela manhã o chefe

lo município deixou o vice-prefeito no comando da situação e embarcou para Brasília onde erá audiência com o Ministro da Justiça responsável pelo processo na tentativa de 爱

uspendê-lo Até não recorrer da decisão o prefeito não reconhece o direito das terras aos ndígenas

O que os cidadãos folhaverdenses estão testemunhando são pequenos grupos que se lizem preocupados com os direitos dos índios quando na verdade estão interessados no patrimônio da cidade Para que os índios iriam querer uma fonte de águas termais? III

A leiteira levantou uma nuvem

branca de espuma

que inundou o fogão

Vó Alma deu um pulo

como se acordasse

com o barulho dos bichos

que cercavam a casa da colônia nas noites compridas 
Morena veio correndo pra conter a correnteza

branca pelo chão

Os braços gordos chacoalhando

com o pano em socorro

Avô Ino começou a tossir forte

segurando nos cantos da mesa

Arrastou a cadeira pra trás

e tapou a boca com as duas mãos

como se um osso atravessado fosse sair pela garganta

As veias do pescoço

saltaram da pele vermelha

Morena bateu nas costas dele

achando que fosse botar pra fora

a casca do pão ou um miolo entalado na goela

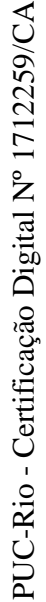

¿ospe Seu Ino

Iospe

Iospe

sse troço

pra fora

Las quando a última tosse veio com força

ele tirou o lenço da boca

e o que saiu de dentro não era pão

mas um marrom seco de terra

que só ele reconheceu 
Enquanto Morena ajudava a resgatar

os óculos tortos no nariz

e Vó Alma assistia a desgraça de braços

cruzados

Gegê que ouvia tudo da gaiola

cantava a única parte do hino

que conhecia com aquela voz de taquara

rachada

Ó pátria amada

idolatrada

Salve Salve

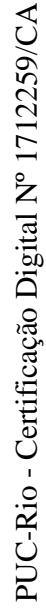




\section{Nota I}

Pousei em Chapecó com uma mala de roupas de frio e outra de livros, na virada do dia $\mathrm{I}^{\circ}$ de abril. Por mais que a data não parecesse uma opção auspiciosa, fui atraído pela ideia de começar e terminar a missão de estudos pelo mesmo número. Número um, número inicial, número iniciático. Chegaria no dia $\mathrm{I}^{\circ}$ de abril e voltaria no $\mathrm{I}^{\circ}$ de junho - não fosse o atraso causado pelos cancelamentos em cascata que a companhia aérea vinha fazendo nos últimos dias. Sobrevoei Chapecó durante a madrugada. Mesmo com o nevoeiro, pude ver como a cidade é pequena. É provável que a minha memória tenha aumentado o seu tamanho depois das notícias em rede internacional sobre o desastre aéreo do time de futebol da Chapecoense. Mas presumo que o desajuste também estivesse relacionado ao meu olhar ntigo, de como enxergava Chapecó como uma imensa capital quando morava na pequena aibi. De fato Chapecó tinha esse estatuto para as cidadezinhas vizinhas, onde as pessoas am comprar eletrodomésticos e consultar os médicos especialistas. Hoje a população é nuito maior. As indústrias do agronegócio se multiplicaram e duas faculdades públicas oram abertas, além das particulares.

Thapecó foi o grande núcleo colonial a partir do qual as pequenas cidades em seu entorno, omo Caibi, se formaram. Este enorme território passou a ser chamado assim em I917, pós uma sangrenta disputa de terras entre o exército brasileiro e milhares de caboclos osseiros, conhecida como Guerra do Contestado. Eliminada a população que lá vivia sem registro de posse das terras, o passo seguinte foi povoar a área para garantir os novos limites. Despovoar para povoar novamente, só que agora com os colonos descendentes de europeus. Ao contrário do ocorrido na época do Império, não foi o estado nacional ou regional que organizou a ocupação das terras tidas como devolutas, mas empresas colonizadoras privadas. A Companhia Colonizadora Bertaso, dona de grande parte do território, ficou a cargo de Chapecó. O coronel Ernesto Francisco Bertaso loteou parte dessas terras para venda e ainda fez doações de terrenos para a construção da cidade. $O$ aeroporto, a praça central e a igreja eram de sua propriedade. O restante, dividiu e vendeu para empresas colonizadoras menores, a exemplo da Companhia Sul Brasil, a responsável por Caibi. Em comum, as duas tinham preferência pelos colonos descendentes de italianos na ocupação das terras. 
Não foi preciso ainda pisar nas calçadas da minha cidade de infância para me sentir nela novamente. A metáfora da cidade já foi utilizada por Freud para ilustrar a capacidade de armazenamento da nossa psiquê. Enquanto os limites do espaço físico impedem que antigas e novas civilizações existam ao mesmo tempo, salvo na forma de ruínas, a psiquê comporta toda a extensão de acontecimentos desde a sua formação. A lógica é a mesma do conhecido bloco mágico, esta outra metáfora do psicanalista para o nosso aparelho mnemônico. Igual ao brinquedo infantil, nossa memória retém de forma definitiva todos os estímulos inscritos na sua superfície. Mesmo depois de apagados pelo tempo, restam as suas marcas. Ainda que sejam imprecisas como os sulcos que ficam no bloco mágico, elas nos habitam em diferentes estratos da consciência. Até as mais primordiais. Se estar em Chapecó correspondia a pisar no mesmo chão da minha cidade natal, era de esperar que a sua geografia despertasse, dia após dia, as memórias da minha formação. Das frestas da paisagem urbana de Chapecó, entre os prédios baixos, surgiam casas de madeira com uintal, características de Caibi. O buffet dos restaurantes chapecoenses tinha a mesma olenta com radicchio, o mesmo salame e o mesmo queijo colonial que se fabrica nas casas o interior caibiense. E o sotaque nasalado dos meus avós, do qual me desfiz depois de antos constrangimentos na capital, saía da boca de todos os moradores de Chapecó. ambém foi familiar, no meio de todas essas manifestações da memória, um enrijecimento rescente no corpo. Depois de viver 7 anos no Rio de Janeiro, dançando nas rodas de ailado sagradas e profanas, a cintura foi a primeira região a me lembrar que estava de olta ao lugar de onde vim. O meu corpo lembrava, assim, do peso com que o nome de henino escolhido pelos meus pais - somado ao sobrenome dos meus antepassados homens - marcavam o meu corpo.

Figura Io - Fotografia do autor durante o desfile do dia 7 de setembro, em I990

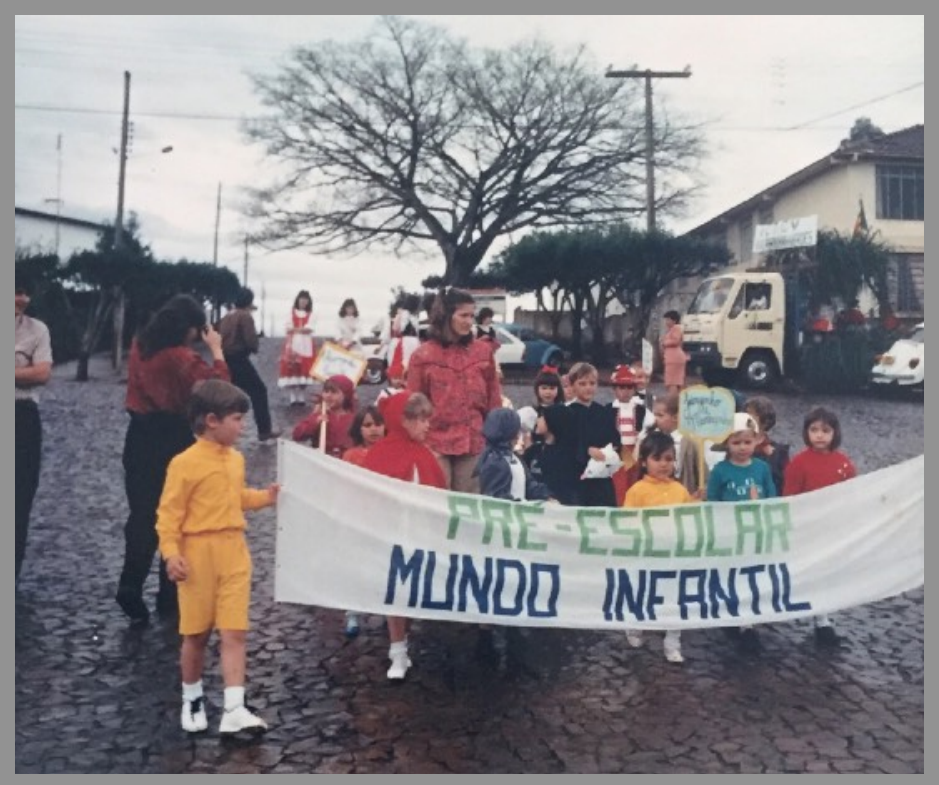



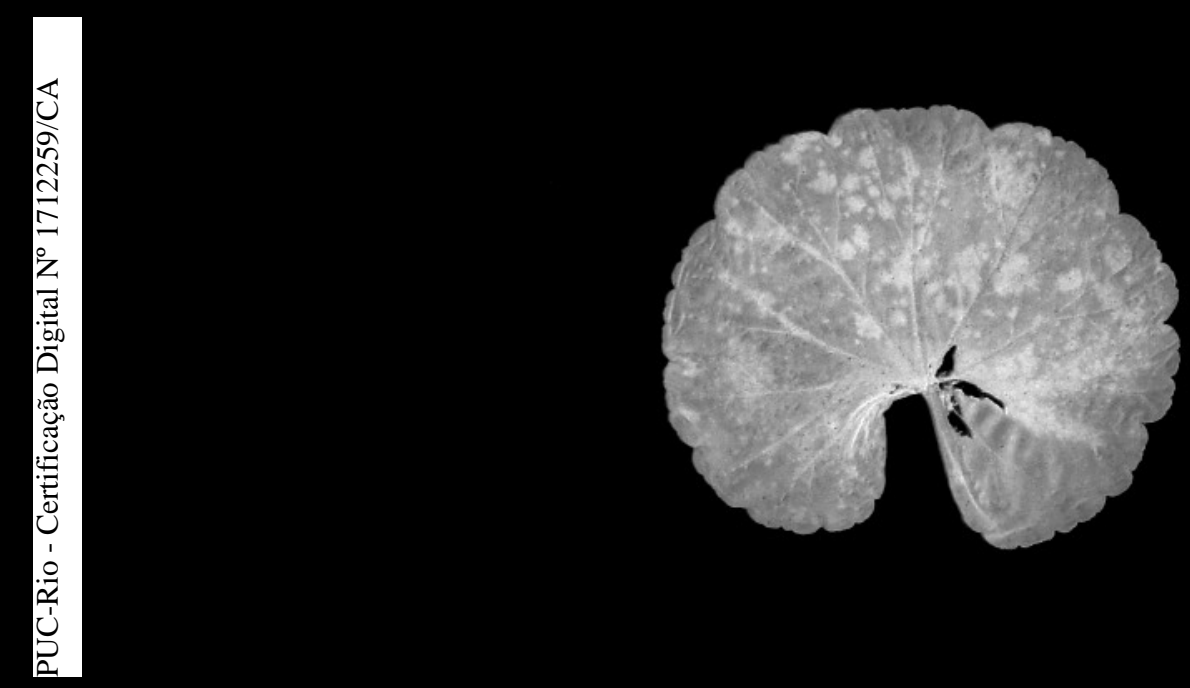

$-2-$ 


\subsection{A chegada na colônia nova}

No dia em que chegaram na colônia do Senhor Leintz

Alma não havia dado nenhuma palavra a Vitorino

desde que o caminhão dera a partida

A balsa de madeira empinava na travessia do rio Uruguai

a cada onda brava

e chocava contra as corredeiras

Agarrada no assento

a mulher não tirava os olhos do cavalo

que já esperava na outra margem da fronteira

em cima da carroceria do caminhão

om as tralhas da casa empilhadas

s sacas de sementes e as galinhas

itorino observava o vestido preto

empapado de Alma

s olheiras caídas

a cara desbotada debaixo do sol

tentava se livrar do peso no peito

O funcionário da companhia

disse que em breve o diretor

vai juntar uma turma de alunos

Parece que ainda não teve

nenhum professor que se ofereceu

pra dar aulas na colônia

Alma tinha a carta que escreveu aos alunos

amassada no fundo do bolso 
Mas não era da escola na capela que lembrava

A cada solavanco da embarcação

o caboclo gritava segurando no leme

e o vento trazia o cheiro das velas queimadas

O corpo do pai estendido em cima da mesa da sala com as flores que ela cobriu até a altura do peito

As irmãs sentadas

ao lado do caixão aberto

o dia inteiro

Na manhã seguinte Alma foi visitar a sepultura sozinha

Voltou para casa

agarrada no pote com os contos de réis que o pai deixara

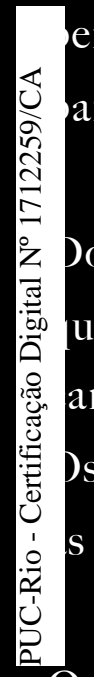

se Tio Ramiro estaria a sua espera

ara sacrificar o cavalo

o portão quem ela viu foi Vitorino

ue gastava o assoalho da varanda

aminhando de uma ponta a outra

Ds braços para trás procurando no chão

melhores palavras

Quando Vitorino percebeu a figura

da mulher

parada do lado de fora

com o mesmo vestido preto queimando embaixo do sol

olhando para o cavalo em cima da carroceria

do caminhão carregado

para a viagem

desceu as escadas correndo ao seu encontro 
Sentado ao volante

o funcionário da colônia nova aguardava pelos contos de réis que faltavam

para garantir o lote de terra

Quando a balsa encostou na barranca do rio e o caboclo enfiou a vara de arrimo no fundo

A mulher descambou até a proa

como se o coice do cavalo

atingisse pelas costas

Segurou nas barras

com as costas curvada

e as águas barrentas receberam

tudo o que Alma tinha por dentro 


\subsection{A cabana da onça}

Chamei Camarada Espingarda pela cerca

Espingardinha como eu preferia

apareceu no quintal da casa ao lado

com os cabelos tosados

Iguais aos meus

só que sem o fiapo na nuca

que Mãe Clara deixava

balançando no estilo do Rei

Roberto

quando passava a tesoura retinho

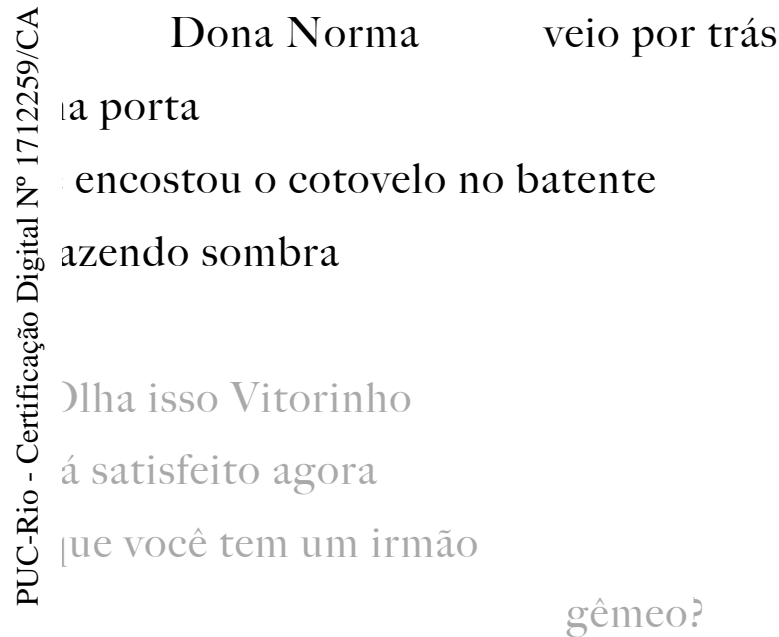

A mãe de Espingardinha ficou furiosa

quando achou os tufos de cabelo atrás da penteadeira

Além das varadas de pessegueiro

o pai de Espingarda

$$
\text { O Armeiro }
$$

proibiu de brincarmos

juntos no grupo de meninos

bandeirantes 
Mal sabiam eles

que os únicos que sobraram

na caravana fomos nós dois

depois que eu deixei Camarada Espingarda

fazer parte do time oficial

com o meu voto que vale mais

Todo mundo sabe que Avô Ino

ganhou o brasão pela bravura

do bandeirante-chefe

e o rabo da onça que ele matou

está no museu de Folhas Verdes

até hoje

ispingarda ficou me olhando

lo outro lado da cerca

sem dizer nada

Jurou só um segundo

mas doeu mais que as injeções

la enfermeira do posto

ue sempre diz

pronto pronto nem foi nada

om a agulha ainda enfiada

no braço

Que depois fica todo formigando

como se tivessem cortado

pela metade

A mãe de Espingarda

começou a varrer o quintal com força

espalhando as britas

pra quilômetros de distâncias

diferentes 
Quando dei meia volta sozinho

pra cabana

o poço seco soltando

miados estranhos pela fresta

da tampa

$$
((((((()))))))
$$

Dona Norma lançou no vento

aquelas palavras dos folhetos da missas

que ela sempre lia no microfone

da igreja

\section{Um dia vocês vão}

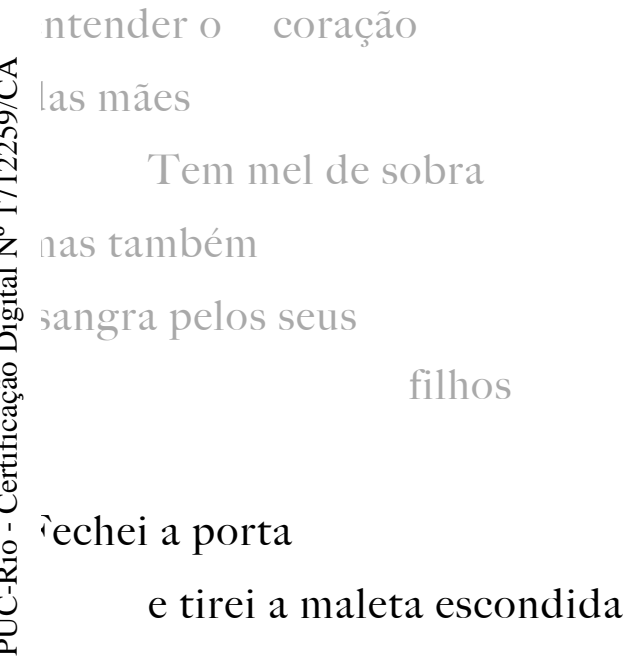

no buraco do chão de terra da cabana

Eu cobria o esconderijo novo

com o tapetinho de ponto-cruz e franjas

que Mãe Clara costurou

pra decoração da sala

Do lado de fora

Avô Ino segurava uma trena

enquanto Casemiro

esticava

medindo o muro

alto 
Passando o parreiral

os pássaros roubando as uvas rubis

as galinhas fofocando no poleiro

Morena batia as roupas molhadas no quintal

Aproveitei a neblina de amaciante

e os lençóis brancos

pra passar a mão no cesto

e sair

disfarçado

pelo meio das pernas

peludas dela

Rolei pra debaixo

la mesa da varanda

ญ̛ nde ficava a fileira de margaridas

sofridas

le Mãe Clara

,onge do radar de Gegê

胥 que vigiava a casa do alto da gaiola

Is migalhas de Vó Alma

spalhadas pelo piso

grudaram igual carrapato

na minha blusa

Nas ruas tudo normal

as carriolas lotadas de bergamotas

o carteiro pedalando na bicicleta o cigarro na boca

e o mercado Copacabana

do Seu Klein

com a praia lotada

na fachada 
$\mathrm{Na}$ praça

o gramado estava tomado

pelas barracas de lona preta dos índios

A fumaça da fogueira

subindo ao lado da estátua

Carros de polícia parados

um

em

cada

esquina

cercando os invasores

até que o prefeito voltasse de viagem

O policial de óculos espelhados

com as mãos apoiadas no cinturão

de pistola grande veio

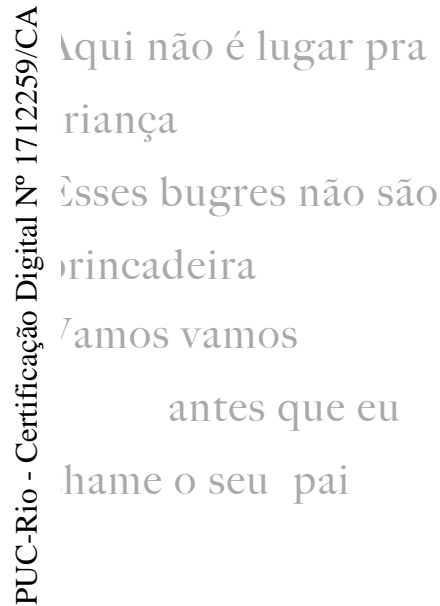

Não sei se o policial conhecia mesmo Pai Vitório mas que ele tinha um rádio-telefone

com antena de longo alcance

tinha

E com certeza

uma ligação desse tipo

chegaria até um orelhão

daqueles que Pai Vitório

manda notícias

dos postos de gasolina 
Avô Ino dizia que um homem

pra ter um nome

não podia ser só de carne

Um homem

pra ter um nome importante

precisa criar a sua história

Ele não sabia que os meninos

bandeirantes me chamavam de

Vitorinhas

Era a chance

de fazer o meu nome

ficar do tamanho dele

Marchei até o balneário das piscinas quentes

inde os índios vendiam vasos de barro decorados

ङ cestos de palha pros turistas

तิ Antes de invadir a praça

¿ les moravam

.

胥

um pedaço de mato

eguindo a trilha do parque florestal

告

Ư⿱

fazia a maior falta

pois disparava com as canelas finas

abrindo caminho

Parava longe

sempre na frente

com o peito estufado

Sem Espingarda junto

tive que inventar essa parte

da bravura 
Tirei os dentes de alho

da maleta

que Morena usava pra espantar cobras

e meti nos bolsos

Comecei fazendo um caminho no parque

seguindo as folhas

menos

parecidas

com as

verdes que nasciam nas árvores

enfileiradas nas calçadas da cidade

Depois guardava todas

entre as folhas brancas

do caderno de couro

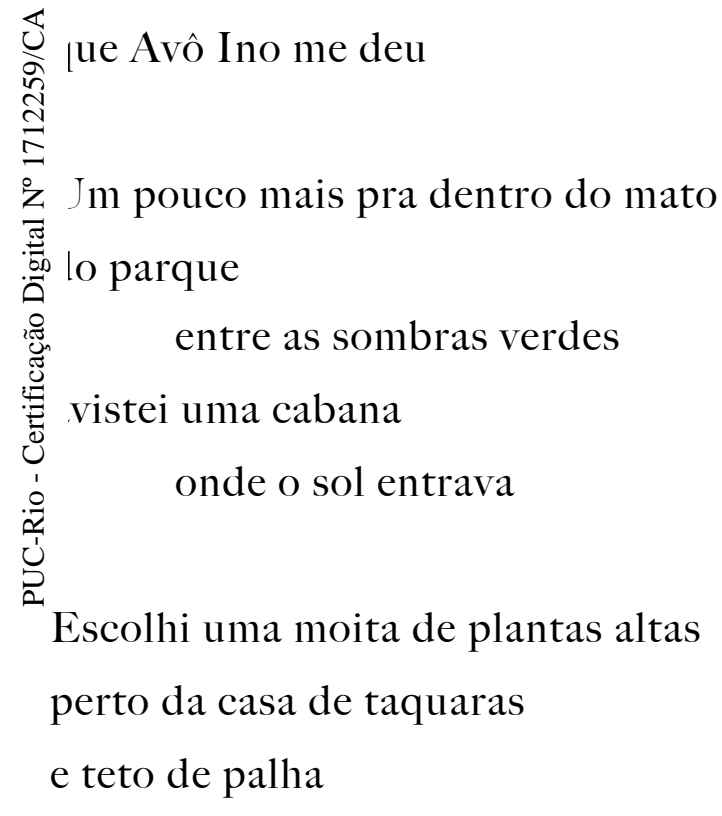

A porta e a janela estavam abertas

passando o ar

De longe o vento trouxe os assobios

dos pássaros vigiando

Estiquei um pouco mais o ouvido

A estação da Rádio Tupi estava ligada

no programa da tarde 
Pela janela

saíam as músicas

que Morena cantarolava

passando roupas

De repente

uma sombra moveu lá dentro

e um braço longo se apoiou no peitoral

da janela

Puxei o binóculos da maleta

pra enxergar de perto

$o$ anel que brilhava

$$
\text { com uma pedra amarela }
$$

riscada

ios dedos grossos

ญ com unhas pintadas

) cigarro soltava

Go umaças redondas que dançavam no ar

Quando a mão misteriosa subiu pra boca

sombreada

ma carreira de pulseiras

penduricalhos coloridos

rolou pelo braço peludo

Não fosse o tiro

que estourou no céu

naquela hora

seguido do foguetório

teria visto sair da sombra

aquela cabeleira amarrada no alto

da cabeça

balançando 
Igual uma onça pintada

escondida na toca

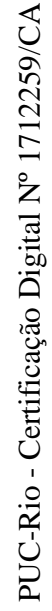




\section{Nota 2}

A especulação imobiliária também é algo que faz Chapecó parecer maior do que realmente é. Depois de uma semana de buscas por um lugar para ficar, desisti de alugar um apartamento e fui tentar as mensalidades de hotel. Encontrei apenas dois deles com um preço justo, a três quadras da praça central. O Hotel Condá, a primeira opção, estampava o nome de um indígena que entrou para a história colonial da região como herói. Munido de armas, título de capitão e recompensas, Cacique Condá encabeçou grande parte dos acordos entre grupos indígenas e colonizadores na ocupação do território. Não só persuadia aqueles a aceitarem o aldeamento do governo, liberando as terras para os imigrantes, como capturava-os para o trabalho escravo nas fazendas. Ao final, acabei nreferindo a segunda opção, com nome de uma comuna francesa. Da janela do pequeno uarto onde passei os três meses, a assombração era outra. Uma vista direta para a torre da greja.

iz uma pesquisa na internet sobre a população de Caibi. Para minha surpresa, dentifiquei um habitante caibiense registrado como indígena no censo demográfico do BGE. Os dados estavam incompletos, informando apenas que a pessoa tinha renda nferior a um salário mínimo e era analfabeta. Nunca havia visto nenhum índio em Caibi. Iais recentemente, alguns deles passaram a vender artesanato na praça durante os finais le semana. Grande parte deles vinha de Iraí, a cidade vizinha do outro lado do rio Uruguai, no Rio Grande do Sul.

Instalado na comuna francesa, tomei um ônibus para Caibi no primeiro final de semana. Três indígenas vendiam artesanatos na rodoviária. Estavam sentados no chão, entre os cestos de palha, dividindo o macarrão dentro de uma sacola plástica. Ficaram acuados com a minha interrupção, olhando desconfiados para minha cara de colono. Apontei para o filtro dos sonhos que balançava na armação de bambu, junto com brincos de pena e pulseiras coloridas. Só consegui esticar a conversa a ponto de descobrir que eram da etnia Kaigang. Sem saber como interagir, deixei o troco do filtro dos sonhos com eles. 



\subsection{Os bichos do terreiro}

No meio da madrugada os cacarejos das galinhas

começaram como uma fofoca rápida

no portão de casa entre vizinhas

Alma despertou do sono acostumado

com o barulho das maritacas

que se metiam no telhado

Os olhos estalados na penumbra do quarto

acompanharam aquela futrica

aumentar para um reboliço

de asas

itorino virou o corpalhão para o lado

massando o colchão de palha

a perna da cama rangeu no assoalho

\section{Pronto}

Is asas se debateram num alvoroço

ma ventania repentina

s bichinhas se esgoelaram em coro

doido como se olhos brilhantes e dentes

afiados

ivesse se destacado da escuridão

Alma sacudiu a montanha de cobertores

onde o marido estava escondido

\section{Você está}

\section{ouvindo Vitorino?}

O homem engrossava a voz fraca

toda vez que a mulher falava alto 
Seja o que for

tá lá fora Alma

Essas galinhas se espantam

com qualquer raposa que passa

no terreiro

Se você não for lá ver

amanhã vou eu

atrás do marido da vizinha

pedir ajuda

No fundo Vitorino sabia

que a mulher nunca ia bater na casa de um moreno

pedindo favores

Mas a ideia de ser colocado ao lado de um caboclo

ez com que levantasse na hora

nrolado na coberta

Com uma mão à frente

lampião abriu caminho no escuro do terreiro

o braço

carabina empunhada

itorino seguiu com passos curtos

até encontrar as galinhas acuadas no poleiro

Elas olharam para o proprietário com os olhinhos pretos

piscando frenéticos

e os peitos inflados respirando ligeiro

Com o ouvido colado nas frestas da janela

Alma acompanhava

Era raposa mesmo? 
Depois de examinar ao redor da casinhola

as penas ainda flutuando na escuridão

Vitorino iluminou a mesma pegada larga

a luz trêmula de querosene

[marcada no chão]

e maldisse o dia que apertou a mão

do diretor

O que você disse

Vitorino? 
3.92 A gaveta de Morena

Morena tinha a cara atracada

no pé de Avô Ino

examinando o couro mole

da sola com a agulha

O pote de álcool ao lado

Ele se segurava no braço

da poltrona sem olhar

a operação

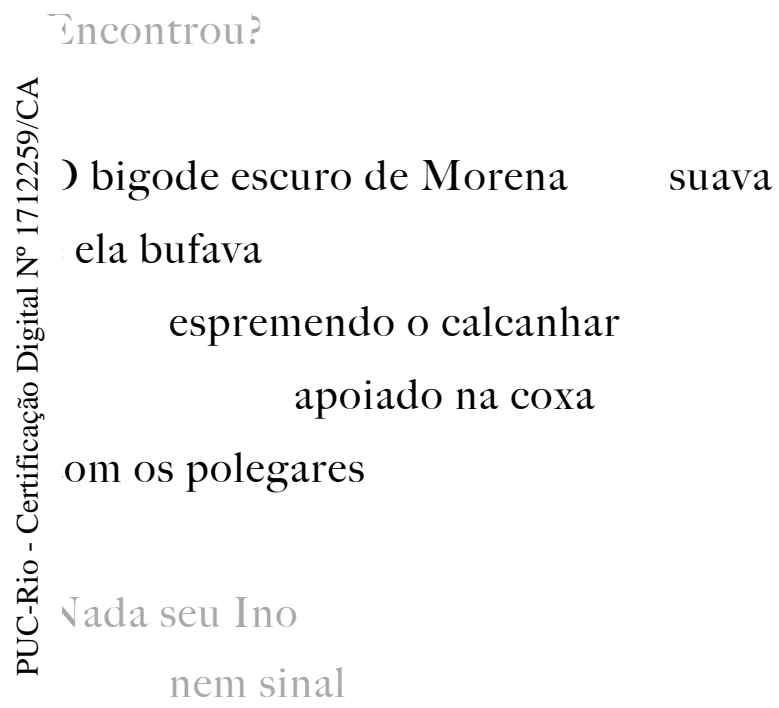

Vó Alma assistia a Missa Sagrada

com volume baixo na parabólica

acompanhando a oração eucarística

com os lábios

Na hora da intercessão ela colocou a mão

no telefone

e espremeu a sobrancelha 
O milagre veio só

pela metade

pois o chamado da ligação

que tocou na mesma hora

não era nenhum dos filhos

que moravam longe

Era Pai Vitório

falando de um orelhão

que comia fichas

na beira da estrada

Morena viu a vó

devolvendo o alto-falante

no gancho

se entocando no fundo do sofá

ङ્ omo uma codorna

doentada

Zू

Tovidade dos netos

ona Alma?

cra só o Vitório

juerendo saber se a Clara

já jantou

Vó Alma andava tão acabrunhada

que o corpo dela parecia encolher

a cada dia 
Nem ligue Dona Alma

Hoje em dia os filhos casam

e esquecem do resto do mundo

nesses condomínios modernos

as casas tudo igual

uma da outra

Nem parece

que os tempos da colônia

acabaram

As buzinadas finas vieram do portão

Morena saltou da cadeira

devolvendo a perna

do avô ao chão

ila foi correndo até o quarto

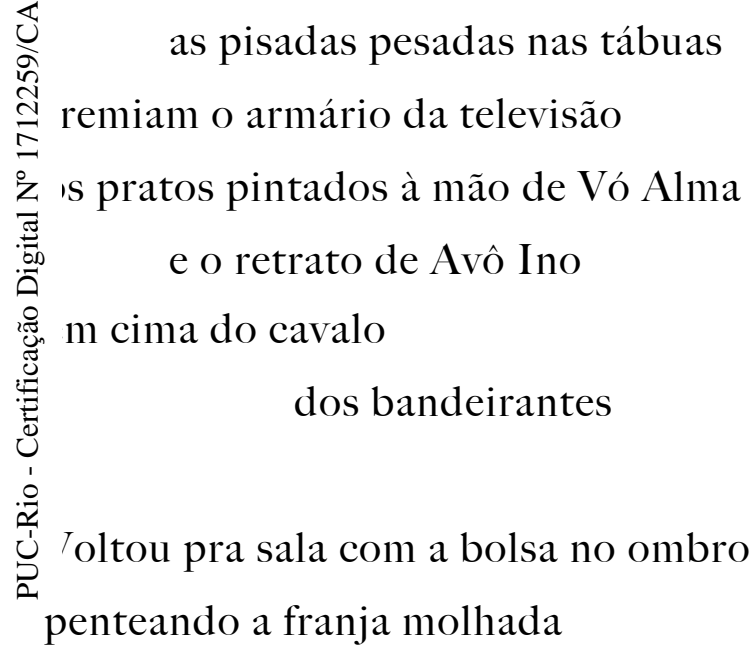

com os dedos

Os peitões amassados

saltando pra fora da blusa

Junto veio uma nuvem de perfume

doce

de calda de pêssego

açucarada

na boca 
Dona Alma

e essas migalhas

todas de novo

minha nossa

Morena foi atrás da vassoura

ligeira

e empurrou os farelos

na pazinha

Vó Alma levantou os olhos

derramados

e ficou medindo as dobras

de gordura apertando a blusa dela

Os zíperes dourados

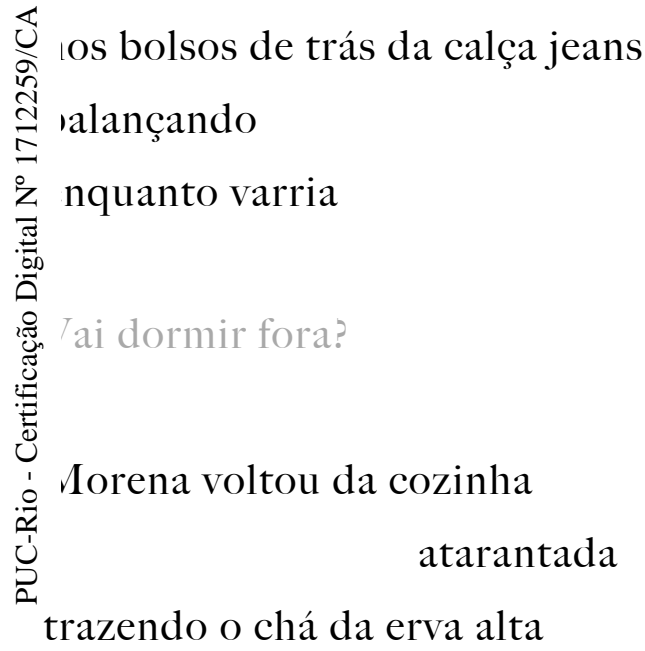

que crescia embaixo da janela da vó

e deixou a xícara

na mesinha do telefone

Seria melhor

não ficar muito

tempo

fora

Esses índios

nunca 
Morena só respondeu

quando chegou na porta

O corpo

todo do lado de fora

Fica tranquila Dona Alma

O Armeiro aqui do lado

anda treinando tiro

pra proteger a casa

O rosto redondo

$$
\text { e risonho }
$$

estalava beijos

pra mim e Avô Ino no ar

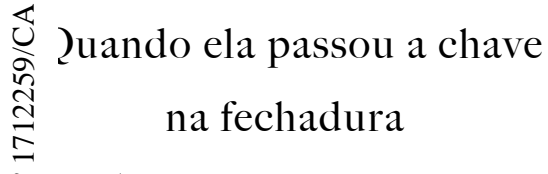

'ó Alma abanou com força

o perfume doce

ois preferia o cheiro

营 de detergente na pele

ínena

ปे Depois de abanada

toda a catinga

tapou a boca de canto

com a revistinha de palavras

cruzadas

Daqui uns dias

essa aí vai ter

que encomendar

as blusas

na costureira 
No quarto de Mãe Clara

o bebê finalmente

$$
\text { tinha dado trégua }
$$

dentro dela

As sombras da televisãozinha

acalmavam ele

fazendo desenhos

na barrigona que nunca tinha

sido tão imensa

nas outras vezes

Pai Vitório

dizia que Mãe Clara

tinha que comer mais polenta

pros filhos

desenvolverem

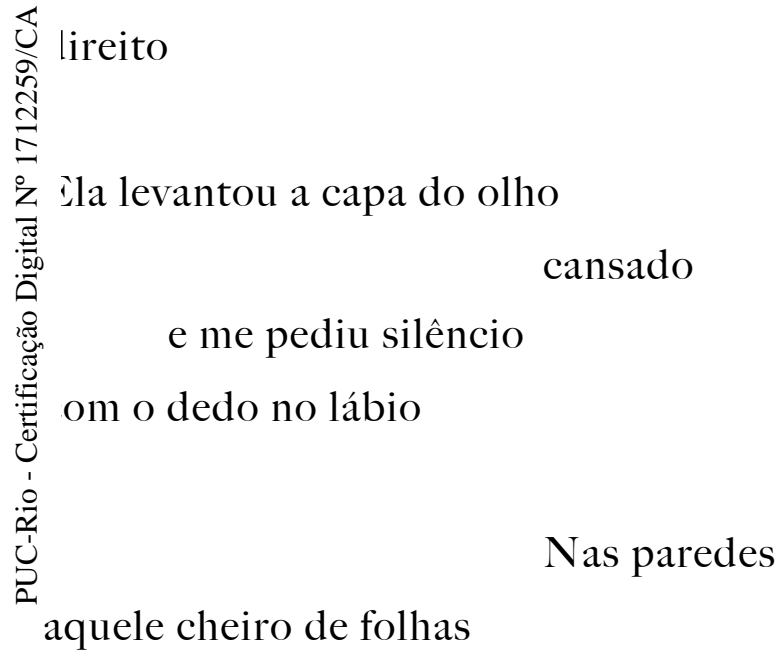

desmaiadas

Da janela dela

Morena e o namorado

se amassavam no tronco da árvore

A moto estacionada na calçada 
Os cochichos saíam

da sombra confusa dos dois

como um grilo

que não dá pra ver o corpo

mas canta no escuro

\section{Riam riam}

como se Morena soubesse

contar piadas

Ela subiu na garupa

fazendo a lataria

encostar no pneu

Jogou o cabelos nas costas

e grudou no cangote do motoqueiro

abraçando a jaqueta preta

Uू lor trás
ปิ ) motor arrancou

$\dot{3}$ com um ronco turbulento

[ue foi afinando até desaparecer

la esquina

Jessas horas

u ia pro meu quarto

onde Morena fazia a cama de baixo

com o colchão magro

E antes de deitar no travesseiro

com o cheiro dela

misturado com amaciante

vasculhava os segredos

que ela escondia na gaveta

do armário

Junto com as calcinhas largas

os sutiãs gigantes

e as saias

curtas 


\section{Nota 3}

A única linha de ônibus que faz o trajeto até Caibi entra nas dezenas de cidadezinhas do percurso. Minha casa da infância ainda está lá e meus avós paternos moram no terreno ao lado. São os meus únicos avós vivos. Os outros também moravam na cidade, a uma quadra e meia de distancia. Ao fazer o caminho da rodoviária até a casa antiga, com a mala de roupas de inverno na mão, atentei para o que talvez não perceberia em outro momento: o nome da rua onde morei, durante a infância, é São Domingos. O primeiro nome dado à cidade quando ainda era uma pequena comunidade. Foi só em 1947, como já mencionado, que a cidade foi rebatizada com o nome de Caibi. O escritor João do Rio tinha uma teoria de semelhança entre o homem e as ruas quando dizia Oh! sim, as ruas têm alma!. E que, aqui, se aplica também à cidade, seus habitantes e seus nomes. João diz que as ruas são tão umanas, vivem tanto e formam de tal maneira os seus habitantes, que há até ruas em onflito com outras. E então eu me perguntava sobre os possíveis conflitos entre São omingos e Caibi; entre colonos, caboclos, diretores das companhias de terras e indígenas ue estiveram presentes em algum dos dois momentos.

vão avisei ninguém sobre a minha chegada, o que causou uma revolução na cozinha urante os dois dias que seguiriam. Dei o filtro dos sonhos de presente para minha vó Irma pendurei-o na passagem entre os quartos da casa e a cozinha. Desta vez meu avô, Carlos, ne reconheceu. Ele sofre de uma degeneração natural no cérebro por causa dos mais de noventa anos e conta com os cuidados de ajudantes que revezam a presença na casa. $\mathrm{Na}$ maior parte das vezes ele me chama pelo nome de um sobrinho que já morreu. E por mais que ele não consiga engajar em conversas sobre o tempo presente, guarda nomes, datas e episódios inteiros dos tempos passados na colônia. Se não ficou feliz pela chegada do neto que mora longe há anos, foi pela presença de um sobrinho com quem conviveu em outros tempos. Enquanto a avó não parava de inventar pratos novos com ajuda da minha tia Nega - que, apesar do apelido, é branca assim como meu pai -, contei a eles sobre a pesquisa que estava fazendo. Em vez de revelar o tema verdadeiro, sobre a cidade, disse que tratava sobre populações indígenas da região. 
Durante o almoço, comentei sobre o habitante indígena que havia encontrado nos dados do IBGE. A história pareceu absurda para todos, até mesmo para a ajudante do dia, chamada Andreza. Depois de ter lavado a louça e colocado meu avô no quarto para cochilar, ela ficou às voltas como se quisesse conversar comigo. Andreza era morena, tinha olhos rasgados, cabelos pretos e lisos. Ela ficara calada durante toda a refeição. Servia o prato do meu avô e depois o dela, sempre vigiada pela minha vó. Tímida, ela começou dizendo que tinha parentescos com indígenas. Uma avó, sobre quem não sabia muitos detalhes, a não ser a conhecida história de ter sido pega no laço por um colono. Além de uma irmã, mestiça como ela, e que se casara com um indígena “de verdade”. O que, nas palavras dela, significava um modo de vida tradicional, ao estilo dos povos originários que ainda vivem nas florestas ou em aldeamentos, como era o caso da irmã. O mais surpreendente viria a seguir, quando afirmou que a informação sobre o indígena que eu havia encontrado na internet não estava errada. E que o conhecia. Ele morava em uma abana no bairro da Gruta, onde viviam os caboclos, falava pouco português e ainda usava trajes de índio de verdade”, como descreveu Andreza sem dar muitos detalhes. Ela não abia o nome dele, apesar de ser conhecido na vizinhança como "índio". Como, de fato, parecem os grupos étnicos que habitavam as matas da região em alguns estudos que nalisam documentos do século XIX. Grafados com a letra inicial em maiúscula: Índio, ndígena. Além dos termos pejorativos como bugres, gentio bravio, bravos, mansos, ;entios bugres, selvagens. O senhor indígena, como eu passei a me referir depois de saber ue ele tinha mais de 50 anos, vivia sozinho. A mulher e a filha haviam morrido de uberculose. O tio de Andreza, chamado Salvador, era a pessoa mais próxima dele. Costumava visitá-lo com regularidade para ajudar com roupas e alimentos. Andreza, apesar da curiosidade, não conhecia o senhor indígena pessoalmente. Depois da morte da mulher e da esposa, a tradição o impedia de conversar com outras mulheres. Então pedi a ela que me apresentasse a Tio Salvador, como o chamava. Mas como ele andava com a saúde frágil por conta do tratamento de quimioterapia, Andreza se ofereceu para intermediar a conversa. Ela parecia muito animada com a possibilidade de me apresentar o senhor indígena, ou de conhecê-lo através de mim. 



\subsection{A reunião dos colonos}

Vitorino chegou na igreja

com o bicho invasor rondando os pensamentos

Pelo alvoroço que ouviu de fora

a reunião já havia engatado nas queixas de sempre

ao diretor

Aproximou-se do banco engolindo o ar

a cara vermelha esfalfada

de varar a picada longa de casa

até a sede

\footnotetext{
S colonos estavam sentados sobre uma ripa

comprida apoiada em dois tocos
}

Im em cada ponta

No meio a madeira vergava com os corpos espremidos

nsnosoutros

s cabeças amarelas

reluziam com os raios do sol que desciam

elas paredes altas de tábuas ainda sem telhado

Com licença

Vitorino pediu um espaço com as costas dobradas

Os colonos empacotados nos casacos olharam para o alto

aquele varapau ruivo com o chapéu amassado no peito

Apesar das caras amarradas

uma ou duas bufadas

se apertaram um pouco mais

para abrigar o recém-chegado da colônia velha 
O homem que esbravejava

com uma espuma branca crescendo no canto da boca

saltou do banco arremessado

pelos corpos comprimidos

Vitorino aproveitou para encaixar a nádega

que tinha ficado de fora do assento

De pé

o colono fincava o dedo como um machado

em cada palavra que lançava ao diretor

Agora o caminhão tá lá

enguiçado no atoleiro da estrada

que nem isso é uma estrada

de verdade

incorajado pelo vizinho

o homem que estava escondido

o paredão de casacos

mendou com a boca mexendo

trás do bigode cheio

Y lá nas picadas de casa

em a carroça passa sem

desconjuntar a

roda

O colono de lábios rachados

continuou as machadadas

com o dedo apontado para o Senhor Leintz

A gente não vai abrir estrada

só com mutirão Seu Leintz

As safras de milho e feijão

estão apodrecendo

dentro das sacas 
O diretor que sempre gaguejava

com o sotaque esmagando as palavras em português

estava com uma calma de querubim

na capela vazia

Perfeito kompanheiro Shuller

O funcionário da kompanhia está

anotando a sua colocação

Quando o kovernador

xegar

Antes que ele pudesse continuar

uma colona com as bochechas tostadas

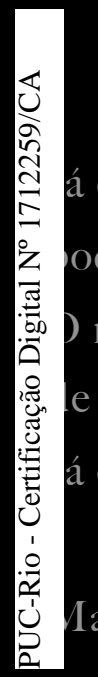

passou na frente

que o homem tá anotando

ode colocar aí o problema dos furtos

milharal lá de casa amanheceu depenado

e novo

á era tempo

que não acontecia

Ias se tu perguntar pra comadre Angelina

que mora do lado do moinho

as laranjeira dela

não duram um dia carregada

né comadre?

O coração de Vitorino correu igual o badalo

da igreja

No meio daquela fogueira

teve a impressão que o diretor

olhou para ele

ouvindo de longe os batimentos

do seu peito 
Com o terno de veludo e a boina escovada

nem parecia que o alemão tinha uma corda

no pescoço esticando a cada dia

que o prazo

de venda dos lotes

corria

Ele pediu ao funcionário que anotasse

o item dos roubos da Senhora Muller

e colocou o ponto final na reunião

Bom kompanheiros

Agora que está tudo anotado

a xente precisa fazer a nossa parte

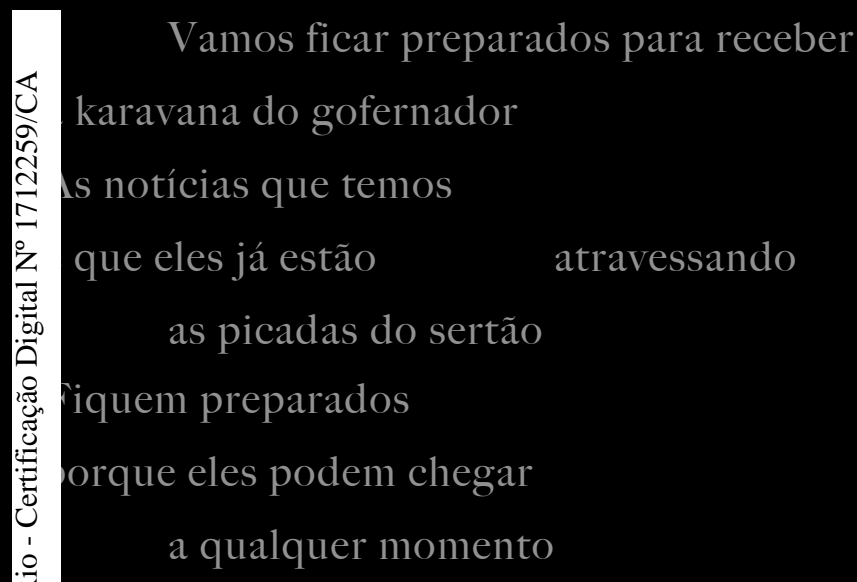

Vitorino aproveitou que alguns colonos

fizeram fila diante do altar

onde estava o diretor

e se esgueirou pela via-crucis

Ao ver o chapéu flutuando

no corpo de dois metros do colono

em direção à porta

o alemão chamou o seu vigia

de volta 
107

Seu Vitorino

Você fique de olho bem aberto na fronteira

Vamos levar os homens do koverno

para visitar a nossa fonte

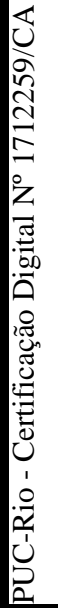




\section{$4.92 \mathrm{O}$ esconderijo do bicho de pé}

Avô Ino tirou a sandália de couro

$$
\text { e as meias finas }
$$

Segurou a perna erguida

fazendo um guincho

com os dois braços

e depositou na cadeira

ofegante

Fui apalpando

com os dois polegares

$s$ almofadas embaixo dos dedos

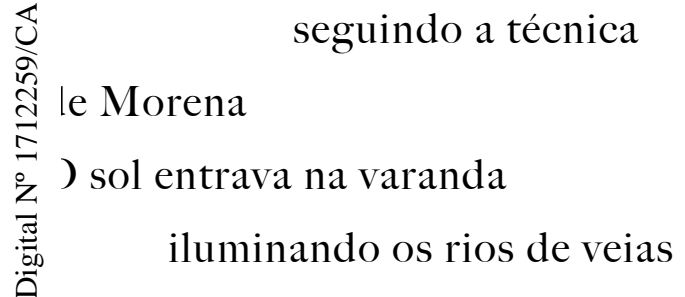

mortas

a pele branca do avô

)s beija-flores se atracavam

nas maria-sem-vergonhas

nos brincos-de-princesa

nas lágrimas-de-cristo

mas passavam longe

das margaridas

de Mãe Clara

Ele tossiu

e o corpo grande sacudiu

como um terremoto nas montanhas 
Passados os abalos

desci pela pele fina

atravessando o meio

da planta

até o calcanhar

III Em viagem à Brasília o prefeito conseguiu suspender a decisão que dava direito aos índios a área de terra de 275 hectares dentro dos limites da cidade Agora ele parte para a capital do estado onde irá se encontrar com o governador em busca de reforços para retirar os invasores do local A polícia está patrulhando a área até que uma solução seja apresentada III

Avô Ino tossiu de novo

arredando os olhos pro terreiro

nquanto empurrava a ponte dos óculos

Ű

ielo nariz

devagar

Morena largou os pratos na pia

veio com as mãos molhadas

e cheias de espuma

estendendo uma colherada

lo xarope de guaco

forte

que a tia dela fazia

Abre o bocão Seu Ino

que pelo visto ainda tem

coisa pra sair

dessa

garganta 
O avô engoliu

entortando a boca

e Morena saiu

deixando cheiro de ervas

com detergente

Avô Ino tentou esticar

as costas curtas de novo

pra ver a quantas

andava a operação

Tá vendo ou não

tá vendo os

bichinhos?

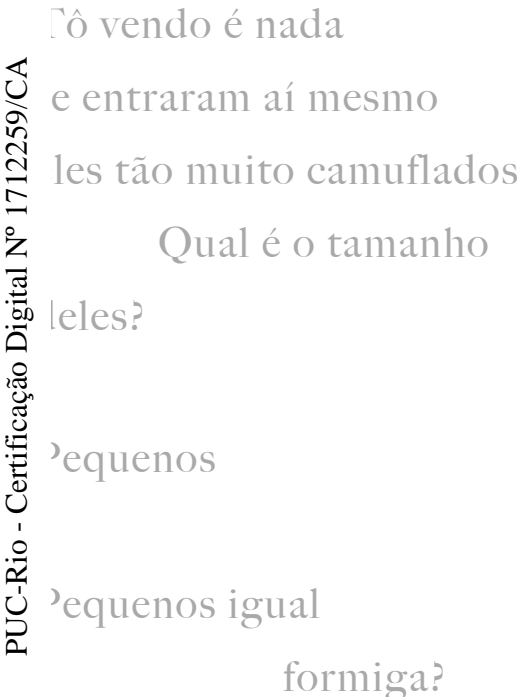

Piolho

pequeno igual

piolho 
Eu nunca tinha visto um piolho

mas Vó Alma proibiu o Casemiro

de trazer o filho dele

porque uma vez

eu fiquei me coçando

depois de brincar com ele

na cabana

Quase desistindo da busca

encontrei

um buraco

escondido

embaixo

da unha

seca

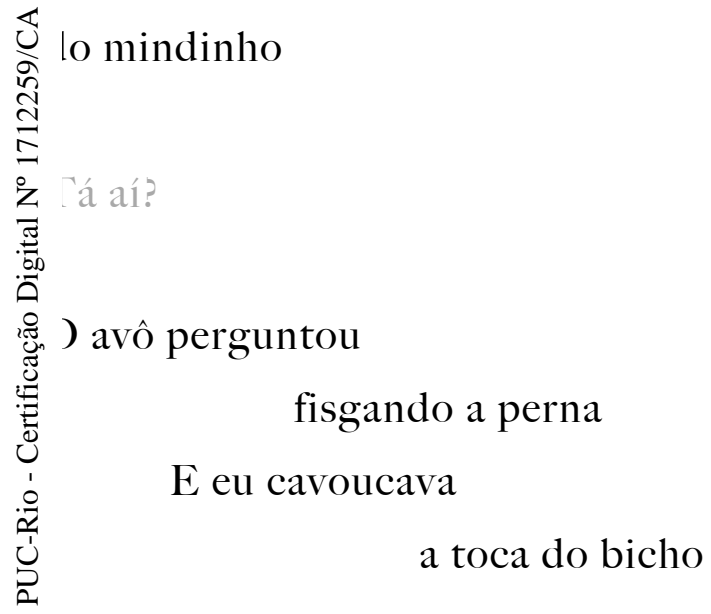

cada vez mais fundo

com a ponta

da agulha

O pontinho preto

que parecia um bicho de pé

legítimo

era

na verdade

pura terra

que Avô Ino tinha

dentro do

corpo 


\section{Nota 4}

Dediquei os dias da semana às leituras na biblioteca da universidade. No primeiro encontro com Arlene, ela me deu de presente uma pilha de livros. As principais obras de revisão historiográfica sobre o assunto da colonização da região. De fato, os estudos sobre as populações nativas de caboclos e indígenas eram muito mais raros do que aqueles que se debruçavam sobre os colonos imigrantes. Contei sobre a descoberta do senhor indígena e ela ficou tão impressionada quanto eu. Chamou a minha atenção para o fato de que uma biografia desse personagem, além de interessante, seria algo a ser feito o quanto antes, a julgar pelas condições precárias em que ele parecia viver. Nem bem nos despedimos e recebi uma mensagem de Andreza pelo celular. Ela havia começado a corrente de comunicação: Tio Salvador havia conversado com o senhor indígena a meu respeito. Itravés do tio, Índio disse já saber da minha chegada. Não perguntei o que significava quilo exatamente, considerando todas as etapas pelas quais a mensagem teria que passar. até porque, o complemento que viria a seguir, através da minha informante, tinha uma nística que, além de sedutora, parecia obedecer a uma outra lógica. Antes de me receber m sua cabana, o senhor indígena iria consultar a lua. Se o corpo celeste, por fim, nanifestasse um sinal positivo, minha visita seria bem-vinda. Com efeito, nada mais ependia de mim naquele momento. Teria que esperar e seguir com o restante da pesquisa. Meu consolo foi crer que, depois de tamanha coincidência, não faria sentido que o meu aminho e o do senhor indígena não se cruzassem. Além disso, Andreza demonstrava tamanha firmeza na condução do encontro, que fiquei confiante com o plano. Para ela, a condição imposta pelo senhor indígena não era um imprevisto. Era um sinal de que eu havia chegado no lugar e na hora certa para registrar a história do único índio da cidade.

Naquela mesma semana, encontrei informações na internet sobre um ritual de ayahuasca que aconteceria no final de semana. A casa espiritual chamada Céu caminhos do amor ficava em uma cidade vizinha a Chapecó e fazia rituais com a bebida ao estilo universalista, igual à que frequentei em Santa Teresa. Combinei uma carona através da página do facebook com um casal de namorados chapecoenses. Cheguei em Coronel Freitas, a cidade vizinha, no meio da tarde de sábado. Coronel Freitas é uma cidade ainda menor que Caibi. É possível ver sua extensão completa da estrada principal, ao longo de menos de um minuto. O carro do casal virou à esquerda na rua de asfalto e, ao final do minúsculo 
perímetro urbano, tomamos um último trecho de estrada de chão até chegar na pequena propriedade. Uma longa fila de pessoas, todas vestidas de branco, aguardava o preenchimento do formulário para a entrada. A cena idêntica a que vi no alto da rua Alice, na primeira vez em que fui na Arca da montanha azul, parecia uma imagem onírica com o deslocamento de espaço e tempo tão comuns na linguagem dos sonhos. Esta impressão era ainda mais forte porque a propriedade era muito parecida à chácara do meu avô. Uma casa grande de madeira, característica dos colonos descendentes de europeus, cercada por um pátio de grama com várias árvores frutíferas.

Depois de fazer o meu cadastro, parei no portão de acesso ao gramado. Desta parte mais elevada do terreno, vi as dezenas de pessoas conversando sob uma lona estendida no chão. Dentre todos os rostos desconhecidos, percebi um rapaz magro e de pele morena. Olhamonos o suficiente para que um dos dois desviasse o olhar. Só depois que o ritual encerrou, no meio da madrugada, ele veio conversar comigo. Ao perguntar o seu nome, a surpresa: Luiz Henrique e o seu?”. É verdade que encontrar pessoas com o meu primeiro nome unca foi algo incomum. Mas a coincidência dos dois nomes, além de improvável, mpressionava pelas circunstâncias. Luiz Henrique tinha um sobrenome de origem alemã Iuestein - apesar de ser moreno como poderia ser um caboclo. Diante do meu próprio ome, pronunciado por outra pessoa, percebi que não usava a versão completa há muito empo. Mudanças de nome são comuns na teoria de João do Rio sobre as semelhança entre is homens e as ruas. E no caso da rua Quitanda do Marisco, ele conta, que cortou o harisco e ficou apenas Quitanda com o passar do tempo, o motivo é a mudança do estatuto ocial. Como indivíduos que organizam o nome conforme a posição que alcançam, ele explica. Assim, as disputas pelo meu nome e o nome da cidade surgiam em paralelo. De um lado, a mudança do meu nome, ainda que sutil, simbolizava uma tentativa de cisão com o nome de família em busca da história individual. Do outro, a mudança de nome da antiga São Domingos para Caibi, serviu para aderir a cidade a um território nacionalizado. Ao nos despedirmos, Luiz Henrique me deu uma folha de presente. Como a que tenho tatuada no antebraço, em referência às folhas verdes que dão nome indígena à cidade. 



\subsection{Um intruso no milharal}

O cavalo vinha resmungando pela picada carregado de farinha enquanto Vitorino se livrava dos galhos que invadiam o caminho Ao sair do túnel de mata fechada enxergou de longe a fumaça que saía pela chaminé de casa

Trotando na estradinha de terra em frente ao seu lote viu o caboclo nos fundos do terreiro

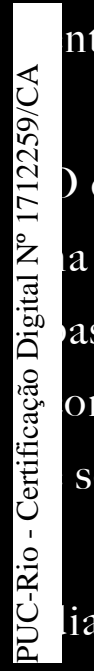
ntrando no seu milharal

colono prensou os calcanhares a barriga do cavalo assou acelerado pelo galinheiro onferindo as bichinhas seguiu atrás dos rastros do moreno

Montado

iante da plantação

observou as coroas de milho mexerem antes de endurecer a voz

\section{Perdeu alguma}

\section{coisa?}

O caboclo saiu por uma das carreiras laterais olhando de baixo da aba de palha para o colono de estatura dobrada no lombo do cavalo 
Vitorino reconheceu os ombros largos

e os braços grossos quando

tirou o chapéu

e enxugou a testa

O senhor não se preocupe

Eu sou o marido da Ramona ali de

baixo

Salvador

A senhora sua dona veio lá no rancho

pedir ajuda

A voz grossa que tinha custado

a subir o barranco

aiu cambaleando
da boca de Vitorino

minha mulher não tá

acostumada

om os bichos aqui da mata

Não pode ouvir um barulho

ue fica assustada

Metido no meio das folhagens

vigiando tudo

de dentro dos olhos rasgados

Salvador não alcançava o tamanho do colono

mas era mais taludo

e falava com uma voz

de trovão em dia de sol 
117

É bom ter cuidado mesmo

Tem muito bicho bravo

que vive nesse mato

Mas o senhor não se preocupe

Quando é milho pouco assim

que some

não é coisa de bicho

grande

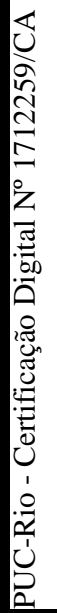




\section{$5.92 \mathrm{O}$ colchão de folhas}

Dona Norma deixou Camarada Espingarda

brincar comigo na cabana

desde que Casemiro

ficasse com um olho aberto

enquanto cortava grama

Antes de liberar

$$
\text { a gente }
$$

ela espremeu a vista

até os rolos

de arame nos fundos

do terreno

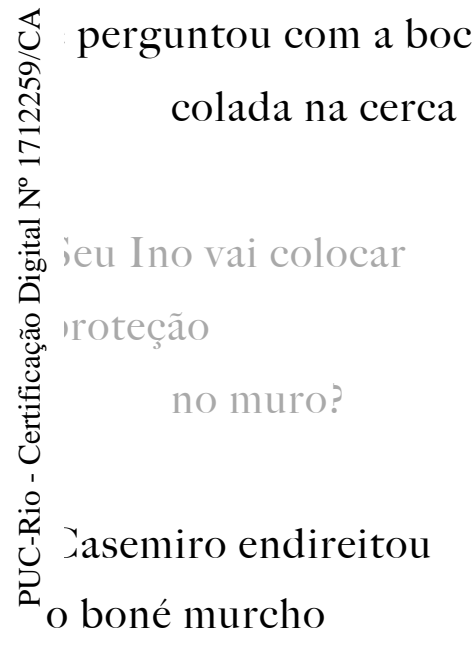

encardido de terra

coçando a cabeça

Ele tá receoso

com os índio

querendo terra

A senhora sabe 
Dona Norma ciscou

$$
\text { a testa }
$$

e balançou a cabeça

segurando o crucifixo

do peito

\section{Melhor isso}

que os tiros

\section{do meu marido}

Que Deus nos proteja

porque se depender do prefeito

a gente vai ter

que brigar

pelas nossas

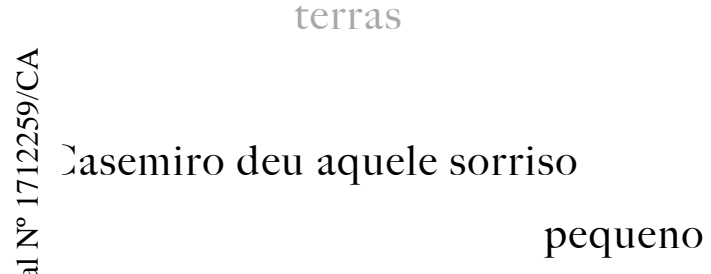

comendo os lábios

ra não mostrar a banguela



ispingardinha

它

suspirou de alívio

de não ter ido comigo na missão dos índios

invasores

Dona Norma fazia jurar

toda vez que a gente ia

pros lados do bairro

de baixo

pra não chegar perto

das cabanas de caboclos 
De resto Camarada Espingarda

não tinha medo de nada

Além de ganhar no braço

de qualquer menino

todos tinham medo do Armeiro

Ele passava os dias

bebendo compota

de pinga

e consertando armas usadas

na garagem escura de casa

Avô Ino disse

que ele ficou desse jeito

depois que voltou da Guerra

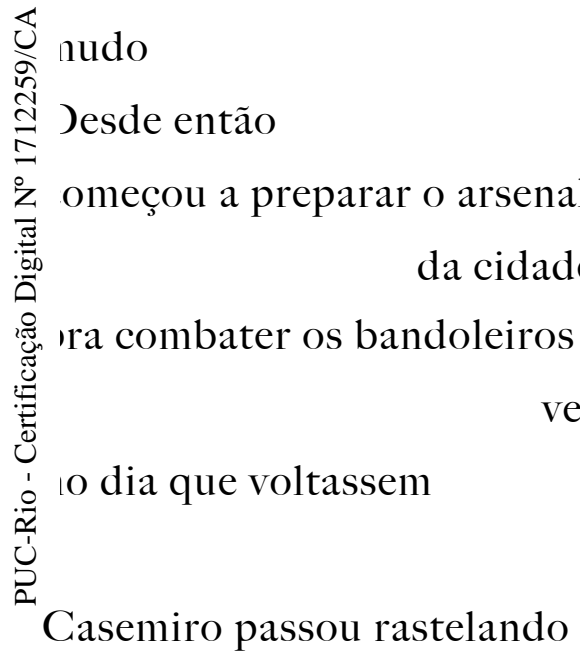

os montes de grama

e assobiando o canto

dos pássaros

que respondiam pra ele

de volta

Fechamos as janelas e a porta

pras folhas mortas não entrarem

na cabana 
Tirei o uniforme

e a peça preferida escondidos no buraco

embaixo do tapetinho

Vestimos

e juntamos as folhas

espalhadas no chão

num colchão

verde

Espingarda deitou primeiro

pois eu tinha medo

das aranhas

que ficam por baixo

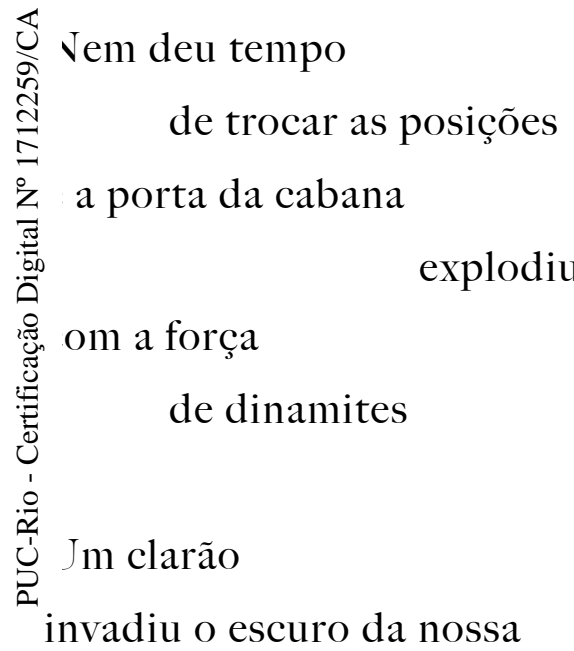

casa

E desta vez não foram os meninos bandeirantes

armando uma emboscada 
Foi o Armeiro

que meteu a cara azeda

de laranja chupada

na porta

olhou a minha pose

e furioso

como uma carreta

destrambelhada no cascalho

entrou na cabana

Derrubou o armário

com as mãos sujas

de graxa

Os soldadinhos de ferro pelos ares

o pote de sementes as enciclopédias

o mate de leite

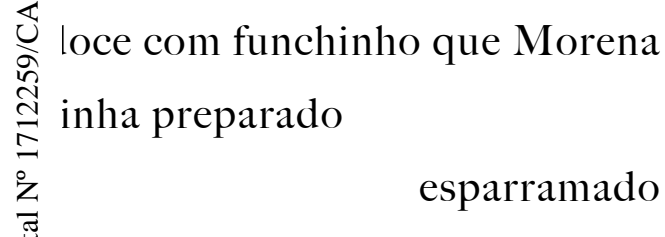

ile bufava

atinga de pinga

com butiá

nquanto tentava

garrar os cabelos curtos

demais

de Espingardinha

Até enganchar

no braço

arrastando com tanta gana

pelo gramado

como se quisesse

cortar pela

metade 


\section{Nota 5}

No meio da semana, Andreza mandou uma mensagem dizendo que o senhor indígena estava decidido a me receber. Nesse intervalo de tempo, porém, ele havia contraído um resfriado. Sendo assim, ela pedia que eu aguardasse mais um pouco, até que ele se recuperasse completamente. Enquanto isto, pesquisei passagens para Iraí, onde ficava a aldeia de um grupo Kaigang. Em um dos registros publicados da viagem de 1929, o bandeirante Arthur Costa conta que Getúlio Vargas, animado com o potencial turístico das fontes de águas termais que lá existiam, ajudou com obras importantes de captação, saneamento, viação e urbanismo. Já naquela época, a empresa colonizadora responsável pelas terras administrava um pequeno balneário. Com a reforma urbanística, a cidade despontou. Uma grande rede hoteleira foi construída para receber turistas, que só umentaram com a abertura do Cassino Guarani. Uma pista de aeroporto chegou a ser berta na década de 1940 para receber voos da Argentina e do Uruguai. O pequeno alneário, então modernizado, ganhou o nome do conhecido médico sanitarista Oswaldo Xruz, mais conhecido pela reação popular a um de seus projetos de higienização, a Revolta a Vacina (1904). A cidade ficou conhecida como "Cidade Saúde".

iz uma reserva no Hotel Iraí, arrumei uma mochila com roupas de banho, além das de rio, e tomei o ônibus na rodoviária. O hotel era um dos mais procurados nos tempos de jória da cidade, com piscinas e banheiras de águas termais. A cidadezinha que, em extensão, não era muito maior do que Caibi, chegou a alcançar um número cinco vezes maior de habitantes. A alegria da cidade começou a ruir em 1947, quando todos os cassinos do país tiveram que fechar as portas por conta da lei de Eurico Gaspar Dutra. Durante a minha infância, quando acompanhava minha mãe nas sessões de massagem e fisioterapia no Balneário Oswaldo Cruz, a cidade já vivia vazia. O trajeto de Belina que fazíamos de Caibi até lá, cruzando a ponte sobre o rio Uruguai, levava uns 20 minutos. Às vezes minha mãe comprava artesanato de alguma criança indígena perto do balneário. Eu ficava encarregado de entregar o dinheiro e de deixar o troco com elas, que estavam quase sempre sujas de terra e com a barriga inchada de vermes. Quando uma mãe queria convencer um filho a tomar banho, era comum dizer a ele que, caso não obedecesse, seria confundido com um bugrinho. Os moradores de Caibi também se referiam aos indígenas de Iraí, os Kaigang, como bugres. Na mesma época em que acompanhava minha mãe nas 
idas semanais à cidade, no início dos anos 1990, os Kaigang estavam disputando as terras ocupadas pela cidade na justiça. Ainda que meu caminho já tivesse cruzado com os Kaigang, não sabia que eram indígenas. Como se a negação ao nome da etnia, encoberta pelo termo pejorativo, os tivesse apagado por completo da minha memória. Também não sabia de onde vinham aquelas crianças barrigudas e sujas de terra.

Não havia quase ninguém hospedado no Hotel Iraí. Vi apenas uma mulher agasalhada e com uma sacola de praia deixar a mesa do café da manhã. Da janela do refeitório via a imensa piscina vazia com os azulejos encardidos. No inverno, os turistas são ainda mais raros. Por conta disto, os Kaingag não estavam na área destinada à venda de artesanatos. Há alguns anos, a prefeitura restringiu a prática ao espaço entre o balneário e o bosque sagrado, como é chamada esta área de preservação ambiental. É ali que os visitantes costumam passear, tomar banho e se abastecer com a água medicinal das bicas. Para além lo bosque sagrado, está o rio do mel. Sem encontrar nenhum Kaigang por ali, fui até a norme estação termal do balneário. Além das piscinas coletivas, havia banheiras de idromassagem e todo tipo de tratamentos estéticos com as águas de mel e seus derivados. edi por uma massagem simples e fui encaminhado para uma sala com vista para o bosque agrado. O funcionário que me atendeu, Seu Neuci, não era um simples massagista. inquanto desfazia as travas da minha cintura, contou que sua especialidade eram os tendimentos espirituais com ervas medicinais, terapia de vidas passadas e conselhamentos. Embora tivesse as feições brancas de um colono, Neuci era de origem rasileira, como se autodefinem os caboclos em oposição aos descendentes de europeus. 'or mais que Neuci tivesse aprendido grande parte dos seus saberes com uma curandeira na sua cidade de origem, Ametista do Sul, também havia compartilhado aprendizados sobre as ervas com os próprios Kaigang. Apesar de desencorajar o contato com eles, por serem imprevisíveis e traiçoeiros na sua opinião, disse que poderia me levar até uma benzedeira da cidade. Quando acrescentou a informação de que ela era, provavelmente, a cabocla mais antiga de Iraí, testemunha viva da fundação da cidade, não pude deixar de pensar que o roteiro que havia organizado estava se cumprindo com a interferência daqueles que eu via como objetos de pesquisa. 

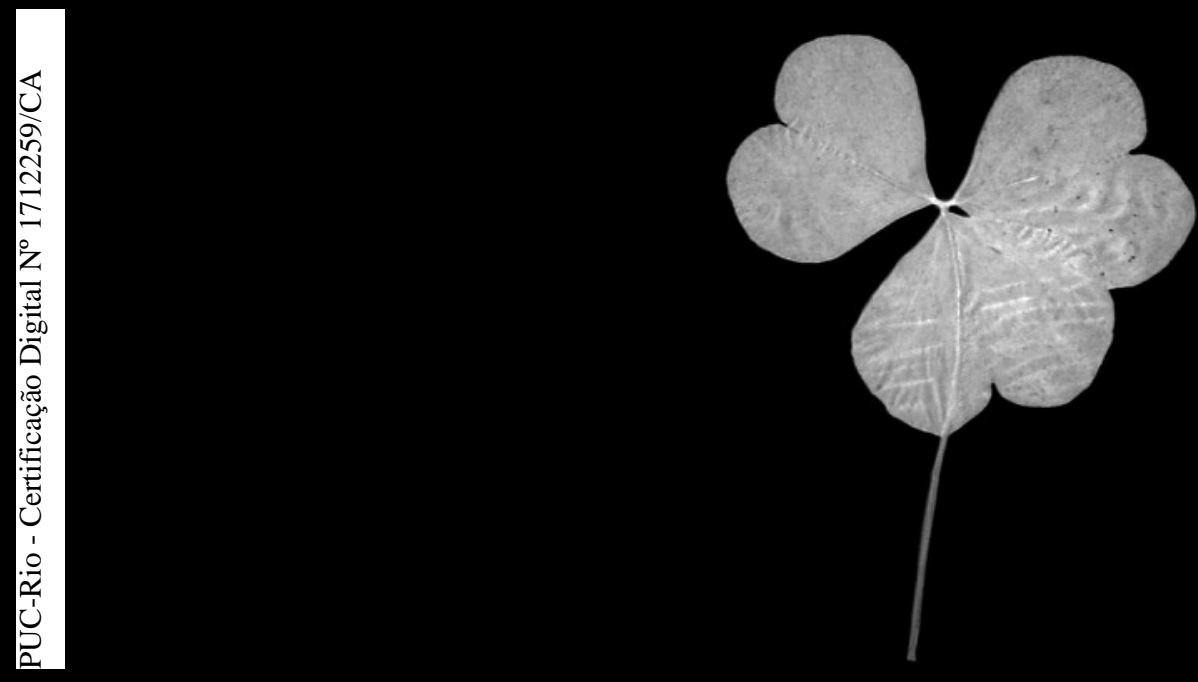

$-6-$ 


\subsection{Catinga de onça}

Vitorino deitou a carabina no ombro cedo

quando a fumaça do fogão se misturava com a neblina

e árvores amanheciam molhadas do frio

Alma varria os montes de folhas

que entupiam as valas do terreiro

e acumulavam nas calhas

Ela juntava os grandes montes

bufando

que avançavam para a porta

e os jogava de volta para o mato vizinho

colono se despediu

enquanto a mulher arrancava as ervas

altas

ue cresciam perto da janela do quarto

gachada no chão

em nenhuma palavra de volta

não ser um resmungo

Vitorino pegou o caminho do riacho

aforando fumaça no vento úmido

s pernas longas passavam longe

das pedras lisas e dos troncos podres

varando o caminho

como um cão esfomeado

e surdo para o aviso do pássaro guardião

Passou distante da beira da enseada

e se agachou atrás da moita alta

com visão para a cabana

Ficou de guarda por um tempo

até o sol despontar detrás das nuvens grandes

e acender a clareira da mata

Quando a luz despertou a sinfonia dos pássaros

o colono se encorajou a explorar os arredores 
Dentro da cabana

só o vento passava

Vitorino puxava o ar pelas narinas

da catinga forte de carne podre que pairava

sem nenhum resto de caça à vista

Da porta para fora

as pegadas largas deixavam o abrigo

em direção à fonte

O colono engoliu seco

e foi seguindo os rastros com o cano da carabina

acompanhando o contorno das pisadas

Quanto mais avançava

mais fundo e mais raso

pareciam as passadas

Como se o bicho

ivesse um trote manco

ou gasto pelos anos

Depois de espiar

se a criatura dona dos rastros

ão estava deitada na orla

eve certeza que o destino dela

ram aquelas águas

de gosto salobro

$\mathrm{Na}$ margem de barro escuro

onde as pegadas paravam

o leito lamacento do rio

aparecia revolvido como lençóis maltratados

depois de uma noite de agonia

E a mesma catinga

de carne apodrecida

misturada no ar 
Quando a rajada de foguetes explodiu no céu

avisando toda a colônia

que a caravana dos bandeirantes estava chegando

o dedo dobrado no gatilho

apertou de susto

disparando um tiro de espingarda

no mato bravo 


\subsection{Carta aos moradores}

Área indígena de Folhas Verdes I2 de agosto de 1992

\section{Caros senhores}

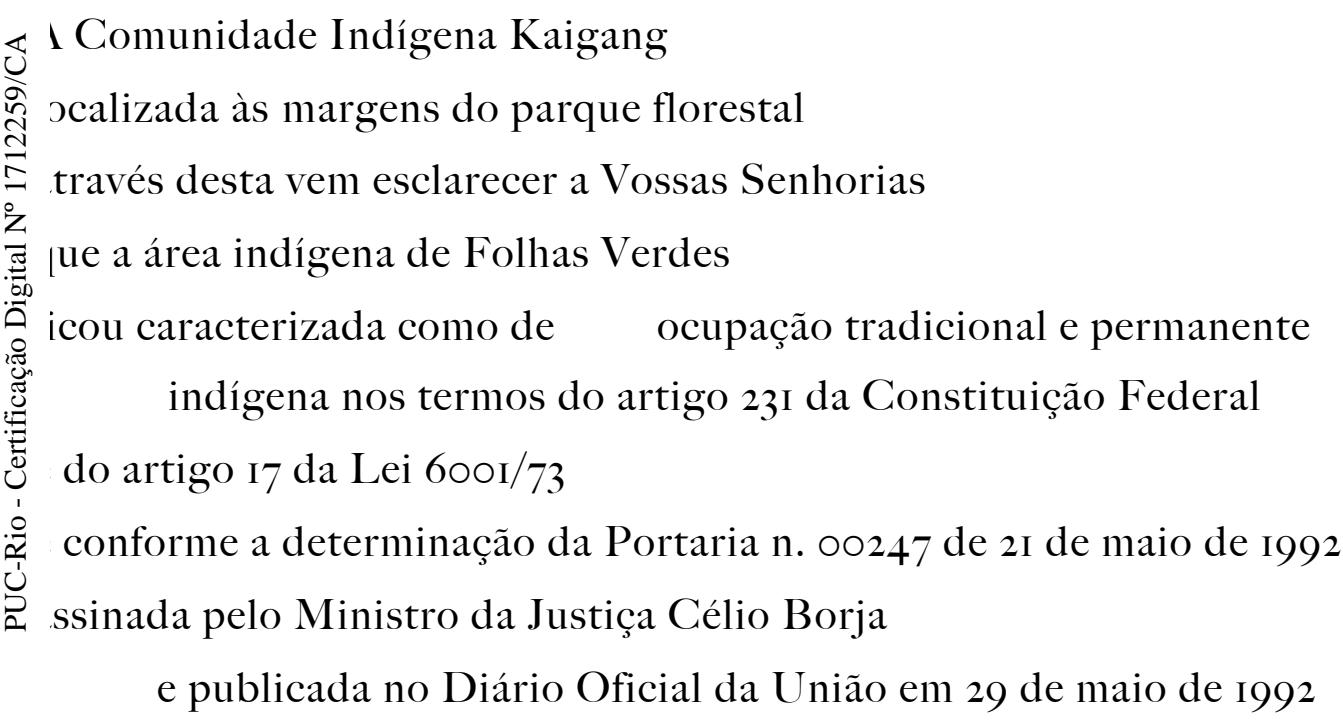

Outrossim informa-lhe que a medida cautelar

da Prefeitura Folhas Verdes não tem validade

pois é posterior à assinatura da referida portaria

Se o Juiz Federal for manter o "status quo"

deverá ser em favor dos índios

pois não existe outro ato que revogue a medida

tomada pelo Sr. Ministro da Justiça 
Considera o item III da resolução da Portaria n. 00247

do Ministério da Justiça

a comunidade local apoiada por diversas áreas

do Rio Grande do Sul e Santa Catarina

resolve fazer a autodemarcação a partir deste dia

e reitera aos Senhores que a Comunidade Indígena

pacificamente realizará este ato

e ainda coloca-se a sua disposição

para apoiar quando Vossas Senhorias procurarem o Órgão competente

para fazer a desocupação da referida

área

Atenciosamente

Comunidade Indígena de Folhas Verdes 


\section{Nota 6}

De volta à biblioteca, comecei a ler um dos livros que Arlene me deu de presente. Ele trazia um compilado de fac-símiles sobre a viagem de I929. Em maio de I929, mesmo mês em que eu estava, a comitiva de Adolpho Konder havia dado início à grande epopeia nacionalizante pelo sertão catarinense. Logo que soube do diário de viagem escrito por Othon Gama D’Eça, vasculhei a biblioteca em busca daquele nome que estampava uma rua transversal à que morei em Florianópolis. Sua função era dar espírito romanesco e aventureir para a obra de brasilidade realizada pelo governo, como ele mesmo definia a expedição. Os seus escritos revelam o olhar de um cronista em contraste ao historiador clássico. Cargo, este, que cabe ao desembargador Boiteux com suas teses históricas do Império - constantemente ironizadas por Gama D’Eça. Atento a todos os detalhes para screver a história da caravana oficial, a narrativa dos dias é uma história aberta. Nela stão os imprevistos sofridos pela caravana, as conversas com os caboclos, os sinais de ntigos indígenas e os barulhos das onças que rondam a floresta. Cruzamentos que correm ao cronista na medida em que se cabocliza, como diria o filósofo das macumbas. Ja medida em que se coloca disponível à travessia e se deixa encantar, exatamente como ivem os caboclos encantados - sempre à espera de corpos disponíveis ao transe, que os ncantem novamente. Assim, o discurso patriótico exaltado de Gama D’Eça aparece cheio le nuances em seus escritos. Neste discurso, curiosamente, as folhas são um elemento lestacado com frequência pelo cronista. Sobretudo as folhas verdes, que surgem como símbolo da brasilidade, da alma brasileira. A qual também se manifesta nos povos caboclos do sertão, aos olhos de Gama D’Eça. Não foi por outra razão que tive a ideia de fazer uma coleção de folhas, a começar com aquela que ganhei do meu xará Luiz Henrique. Como se fosse um personagem escritor, colecionando as folhas que encontrasse ao longo da minha incursão.

Depois de algumas buscas em papelarias, topei com uma feira de artesanatos no pátio da universidade. Bati o olho na mesa em que estavam expostos os cadernos artesanais com capa de couro. O vendedor era um rapaz que usava um gorro estranhamente pontudo. Ao ouvir atentamente a minha ideia, disse que poderia incluir folhas de papel vegetal entre as páginas para ajudar na preservação das folhas. Ele anotou o número do meu celular e, alguns dias depois, enviou uma mensagem para combinar a entrega. Com o contato, 
descobri que o seu nome era Luiz. Desta vez, Luiz Carlos - nome composto que unia parte do meu e do meu avô. Quando cheguei na praça central, Luiz Carlos estava me esperando na frente da igreja com os seus longos cabelos soltos, antes escondidos no gorro. E o meu caderno de folhas cuidadosamente embrulhado. Ao fundo, logo ao lado da paróquia, estava o monumento chamado Desbravador. O corpo de Luiz parecia minúsculo diante da imponente escultura de bronze do colono imigrante. O Desbravador rende homenagem aos colonos que construíram a cidade, sobretudo aos descendentes de italianos como meu avô, que tiveram preferência nas negociações de terra com a Companhia Colonizadora Bertaso. Do outro lado da rua, na mesma altura do enorme colono com chapéu, machado em uma mão, e um ramo de erva-mate na outra, estava também o famoso Hotel Bertaso. 

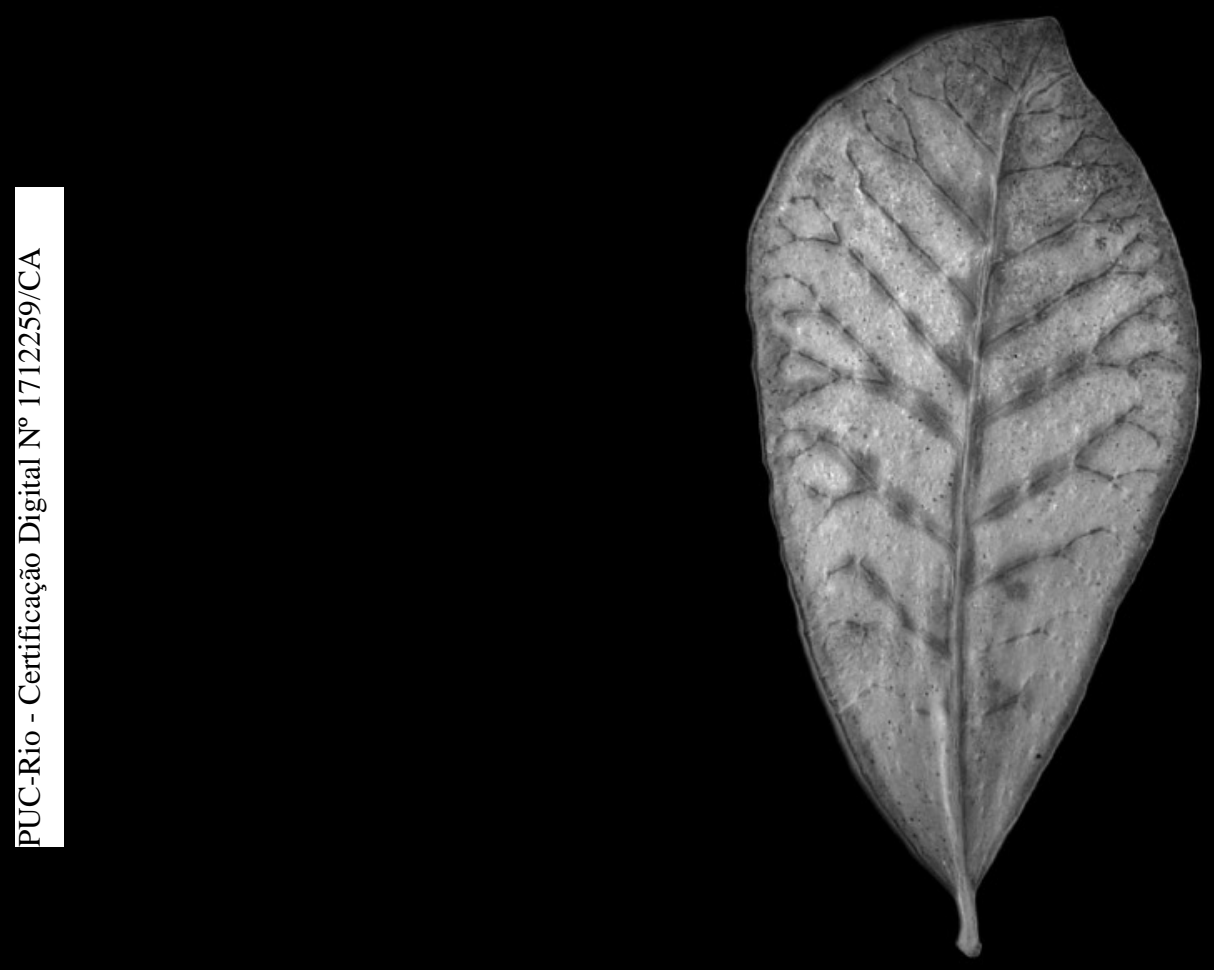

- $7-$ 


\subsection{Um bandeirante pede abrigo}

Os colonos esperavam em pé

no meio da praça

que era apenas um terreno quadrado

de capim cortado

sem canteiros de flores e árvores enfileiradas ainda

As mulheres já haviam ganhado permissão para sentar

no chão com cuidado para não amassar

as roupas de domingo

Quando

o funcionário moreno da companhia

viu uma mancha no horizonte verde azulado

oberto com um lençol de neblina

isse espremendo a vista

Parece até uma cavalaria fantasma

flutuando na nossa

ireção

mpressionado com a visão que avançava

pela trilha das araucárias

correu o badalo do sino na igreja

$$
((((((()))))))
$$

$\mathrm{Na}$ frente da tropa vinha o chefe

governador do estado

Montado no cavalo lustroso

e penteado

acenava como um desbravador

do passado 
Assim que puxou as rédeas

o animal obedeceu

estacionando como um automóvel

\section{Saudações Senhor Leintz e}

a todos os trabalhadores que nos

recebem de braços abertos

Alguns dos homens oficiais encostaram

logo atrás do chefe bandeirante

batendo continência

enquanto o restante da comitiva

estacava

antes da linha de chegada

Apesar dos sombreiros e das carabinas nas costas

otas e ponches de lã grossa

Vitorino notou que os famosos bandeirantes

ão tinham a mesma aura de herói do primeiro

quele sim

obusto e corado das geadas

sentado no pelego sobre a sela encouraçada

aba do chapéu um pouco inclinada

omo em um retrato batido

arecia o único sobrevivente da comitiva arrasada

com aqueles homens de rostos magros e abatidos

depois varar dias e noites no coração verde

do sertão

O foguetório queimou no céu limpo

e os colonos começaram a entoar o hino nacional

em posição de sentido conduzido pela pequena orquestra

Durante o coro vigoroso e disciplinado

Vitorino observou o governador inquieto

a mão em concha

falando ao pé do ouvido do diretor 
Do lado dele

o homem balofo com um papagaio no ombro

espichava o pescoço concordando sempre

com ar de imperador romano

Ao final da estrofe

Ó Pátria amada idolatrada

salve salve o diretor deu um passo

à frente com seus sapatos engraxados

e interrompeu a cantoria

Minha xente kompanheira

Nós sabemos o quanto estamos ansiosos

mas o governador Konder

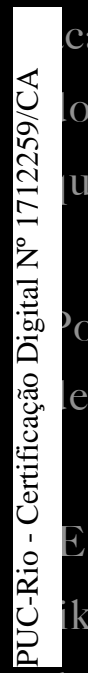

aba de receber um konvite

o governador vizinho

ue quer estar presente

na sua passagem

or hoxe vamos oferecer

escanso e boa komida

para os nossos bandeirantes

as nossas homenaxens

kam para a chegada

do ilustre homem

de estado

Não é todo dia

que homens oficiais

visitam uma kolônia

no meio desse sertão

não é verdade? 
Dito o imprevisto

Senhor Leintz deu ordens

aos funcionários para que encaminhassem

os homens mais combalidos

até o alojamento da companhia

Os bandeirantes caminhavam pela sede

como soldados mudos

retornando de uma batalha

Os colonos se aproximaram da comitiva

como crianças diante da carriola de doces

Com os olhos piscando

e as mãos afoitas

ofereciam ajuda para carregar as bagagens

té suas casas

Vitorino enxergou ao fundo da aglomeração

homem que puxava

as rédeas de um burro espigado

or de pinhão

intregue o animal a um dos funcionários

inha em direção à praça carregando uma mala estufada

Testia um terno de corte fino amarrotado

e trazia uma maleta de couro duro com detalhes dourados

pendurada no ombro

Apesar da disposição

tinha uma sombra de perturbação no rosto

que fisgou o olhar do colono

No momento em que o sujeito

cruzou com os olhos curiosos de Vitorino

topou num pedregulho e foi ao chão

A maleta abriu esparramando seus pertences

binóculos máquina fotográfica lanterna

um caderno de couro e

uma pistola 
Vitorino correu até o homem

e o ajudou a catar cada um dos objetos

Vitorino às suas ordens

O homem levantou com o olhos aterrados

no rosto sarapintado do colono

Depois de espanar a terra

cravada nos joelhos do terno com um lenço

em silêncio

o bandeirante arreganhou os lábios para um sorriso

que saiu com ar de desespero

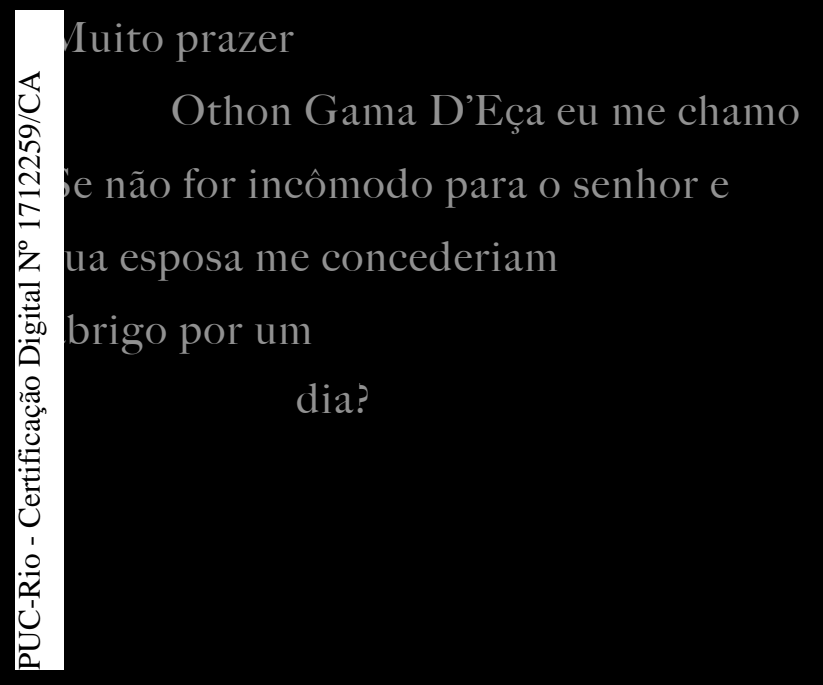




\subsection{Bucho de terra}

No meio da noite

os passos tombados de Avô Ino

perambulavam pela casa

girando tramelas

e balançando chaves

Acordei com a mão de Morena

provando a minha testa

quente de febre

Ela colocou compressas

de vinagre gelado

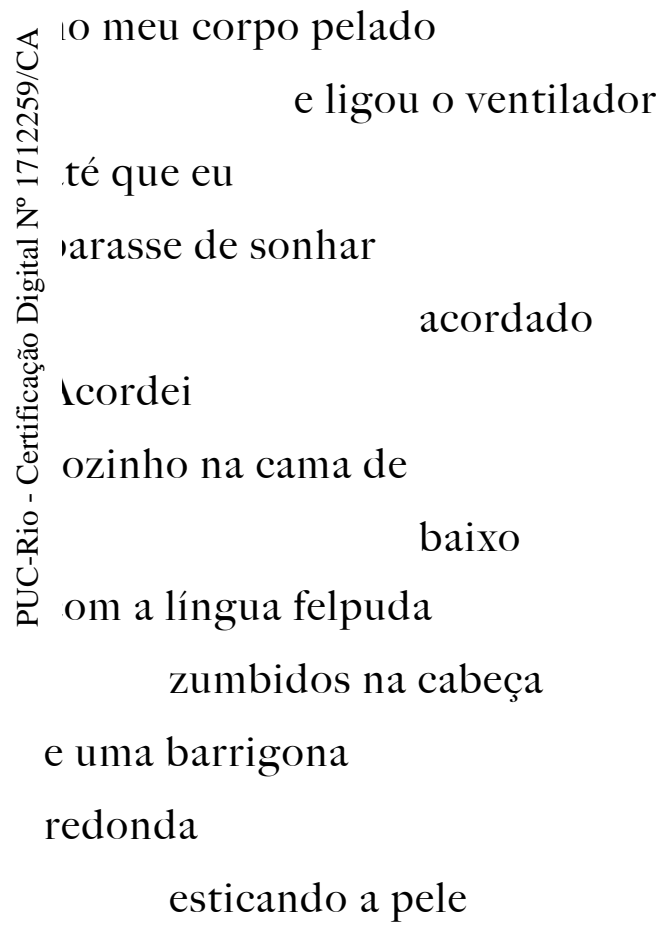


Mãe Clara pediu

que Casemiro guiasse o Del Rey

cinza de Avô Ino

capotado de sono

depois da ronda da noite

até a casa da Dona Ramona

no bairro de

baixo

Seu Serafino

abriu a cancela

\section{Vamos se achegando}

que a mãe tá rezando pros

\section{loente dela}

ญ્

Morena contava que a tia

azia caridade telepática

Ouvia o nome

:os doentes e falecidos na rádio

enviava

o tratamento à distância

om os olhos

fechados

A velha morena

botou a mão na testa

quando entramos

na sala

Parecia preocupada

mas era a pálpebra

caída

que resgatava

pra cima

do olho leitoso 
A senhora

Dona Clara

precisa ver essa barriga

direito

Mãe Clara me puxou

pra frente da barrigona

dela

como se pudesse esconder

da benzedeira

sentada numa cadeira

estofada de travesseiros

Não não

Dona Ramona

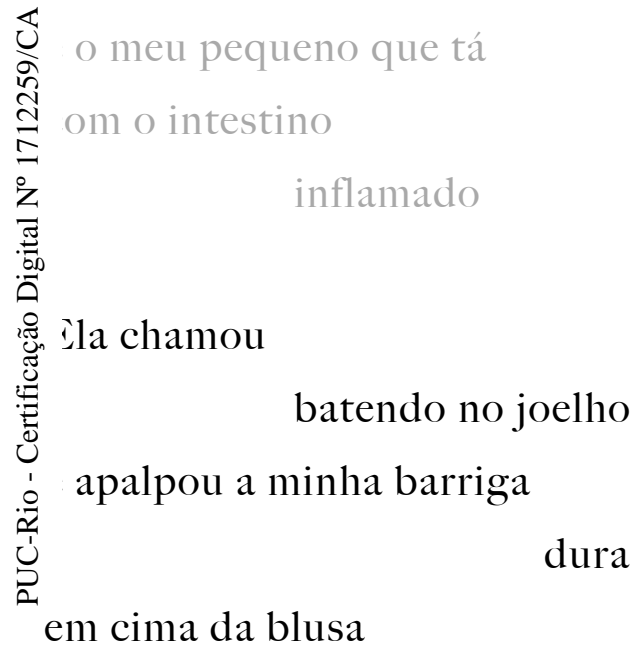

Depois virou

pro Serafino

Leva esse menino

lá fora

com a bacia

e o purgante

pras bicha 
Mãe Clara tapou

a minha boca

até eu engolir a colherada

cheia do óleo

viscoso

Ramona entrou no mato

alto

dos fundos da casa

as madeiras raiadas de preto

e a cerca baixa

Não tinha horta de salada

separada

nem canteiro de flores combinando

ङ )s pés de mandioca

तิ

ㄱe misturavam

Z om as bergamoteiras

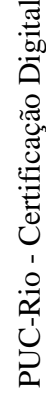

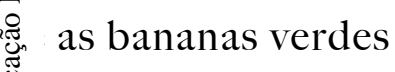

Jm mamão

naduro no alto

igual uma teta

cheia de leite

Ramas de abóbora fazendo caminho de cobra

e o capim rasteiro

esparramado

por tudo

sem lei

A velha voltou

apoiada na

$$
\text { bengala }
$$

com um chumaço de folhas

sortidas 
Puxou o terço

colocou a mão na minha cabeça

e começou a rezar

com a mesma técnica

de Vó Alma

repetindo a oração

com os lábios quase

fechados

E virou pro Serafino

que acompanhava a reza

em posição de espera

igual na fila da hóstia

Pode tirar a roupa

lo menino

Uू

ปิ

Iãe Clara sentou perto do tanque

No meio amassado do alumínio

le tinha largado uma

rapadura

ن

porque o bebê

pesava demais

nas pernas dela

Agarrei na borda da bacia

quando Dona Ramona começou a bater

as folhas

na minha cabeça

Varreu as costas

falando baixo com a voz

funda 
Cantava um canto sem palavras

\section{conhecidas}

Mas que repetia

e repetia e repetia e repetia

até que as palavras criaram

um corpo bem dito de caboclo

invisível

A cada volta

ao redor da bacia

o vestido largo assoprava

o meu rosto

As galinhas corriam

doidas pelo terreiro fugindo do cachorro

) suor gelado escorria pela espinha

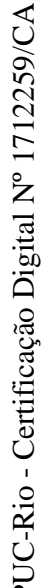

e a barriga parada

emexia

¿u não queria

não na frente da Ramona

ue leu os meus pensamentos

na hora

iorque fincou o calcanhar

rachado igual a terra

quando grita de tão seca

O corpo do caboclo

invisível

tinha um braço forte

que puxou a bicha

pra fora

de uma vez 
Mãe Clara

não conseguiu tapar a boca

$$
\text { a tempo }
$$

quando a voz rouca

da Ramona soltou o corpo liso

$$
\text { e comprido }
$$

que escorreu no alumínio

Expulsada a bicha

Serafino trouxe a mangueira

e fez um chuveiro

$$
\text { embaixo do sol }
$$

Antes de ir embora

enquanto eu tomava o chá

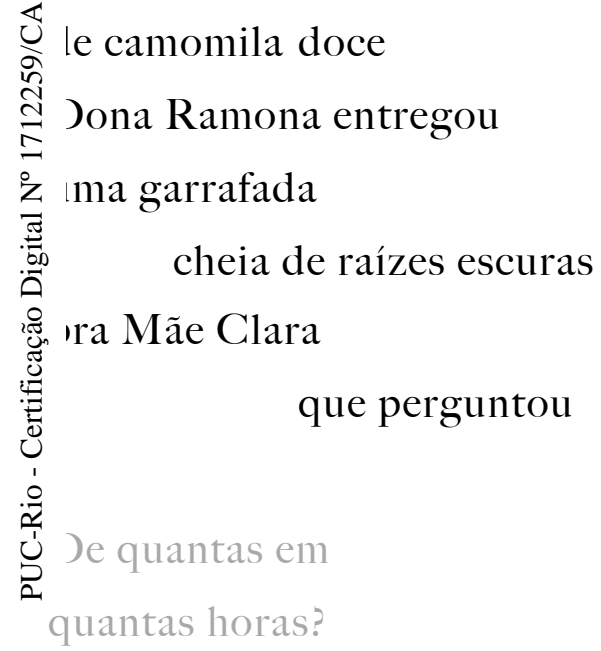

Não não

Dona Clara

Este é pra senhora

O menino tá sarado

Só ficar de olho pra não

encher mais o bucho de

terra 


\section{Nota 7}

O senhor indígena continuava com sintomas da gripe. Andreza me atualizou do seu estado durante a semana, dizendo que uma estranha febre persistia. Era só uma questão de tempo, ela garantia. Mesmo assim, decidi passar o final de semana em Caibi, na expectativa de uma reviravolta. Chapecó fica deserta nos finais de semana e o quarto do hotel era minúsculo. Pela vista da janela, além da torre da igreja, agora identificava os ramos de folhas erguidas para o alto do Desbravador. Antes de embarcar no ônibus, fui até os Kaigang que ficavam na entrada da rodoviária e comprei mais um filtro dos sonhos, desta vez para Andreza. Fracassei novamente em alongar a conversa. Eles se intimidaram rapidamente com a minha presença. E eu, constrangido, com a minha cara de colono. Desta vez, além do troco, dei o meu pacote de salgadinho para as crianças.

Minha vó ficou visivelmente enciumada quando dei o mesmo presente para Andreza. egundo Vó Irma, Andreza havia engordado depois que começara a trabalhar na casa. O ue a fazia fiscalizar, com frequência, as comidas da geladeira e da dispensa. Durante o Imoço, contei a eles sobre a viagem até Iraí, mas que ainda não havia conseguido visitar a ldeia indígena. Ao mesmo tempo havia conhecido uma cabocla benzedeira chamada Tia ata, sobre quem também lhes contei a história, na tentativa de encontrar algum ruzamento com a de meus avós. Todos os irmãos de Tia Iata trabalharam como balseiros, ransportando viajantes e mercadorias de uma margem a outra do rio Uruguai. Foi exatamente nessas balsas que meus avós passaram da antiga colônia no Rio Grande do Sul para o lado de Santa Catarina. Um dos detalhes que ouvi ainda criança era a carroceria do caminhão atulhada pela mudança. Além dos pertences mais importantes, levavam consigo galinhas e o cachorro. Como grande parte dos habitantes de São Domingos, meus avós chegaram na comunidade no final da década de 1940. $\mathrm{Na}$ onda das medidas tomadas pelo governo em 1929 e que fizeram a região expandir economicamente.

Logo que meus avós chegaram, instalaram-se em uma região próxima à pequena São Domingos, chamada Linha São Jorge. Foi lá que meu pai e minha tia nasceram e onde todos eles conviveram não só com outros colonos imigrantes do Rio Grande do Sul, mas também com os caboclos. O vizinho mais chegado da família tinha o curioso apelido de Brasil. Ouvi diversas vezes que, apesar de ser brigão e encrenqueiro, foi ele quem ensinou 
meu pai a dirigir caminhão aos 5 anos de idade e a beber cerveja. Por mais que a convivência fosse assídua, nunca souberam me dizer o nome verdadeiro de Brasil. E o mesmo acontecia com o seu companheiro, também próximo da família e a quem chamavam Catengo. Apelido, segundo eles, em alusão aos hábitos precários de higiene. O que fazia pensar que o apagamento dos nomes não se tratava de esquecimento, mas de outro tipo de tratamento em relação aos nativos. Possivelmente pelas mesmas marcas que apareciam nos registros dos bandeirantes em relação aos caboclos - dados às práticas degeneradas, hábitos anti-higiênicos e propensos à criminalidade. Neste dia em que as conhecidas histórias dos meus avós se repetiram, duas novidades surgiram. A de que meu pai havia nascido pelas mãos de uma parteira cabocla - junto ao detalhe de que estava embriagada durante a operação e que havia usado uma balança de alimentos para pesar o bebê. E, ainda, que meu avô havia trabalhado na construção do aeroporto de Iraí, ao lado de outros caboclos, como Seu Neuci, o massagista do balneário. 


$$
11
$$




\subsection{O bandeirante é um escritor}

O cozido de Alma esquentava mais a casa do que perfumava

Os legumes já estavam pálidos

e a carne desfazendo de tanto ferver na panela

A polenta pronta há horas

dura na travessa

e nada de Vitorino voltar da ronda

na fronteira

Quando o colono abriu a porta

com os braços carregados de lenha para o fogão

encontrou o bandeirante debruçado com uma lupa na mão

\section{obre uma das trepadeiras que penetravam}

elas frestas

a casa e se alastravam

pelas paredes

senhor Vitorino

or acaso sabe o nome

essa espécie?

O colono descarregou os gravetos

e parou diante da cabeceira da mesa de canela

onde estava o caderno de couro

do bandeirante

com folhas de todos os tipos

enfileiradas 
Tão intrigado que estava com o caule

seguindo o seu cumprimento com a lente

o visitante não percebeu

que o dono da casa

estava plantado de pé

diante do seu lugar na mesa

que havia derrubado sozinho

com o machado

Dona Alma disse

que vai me levar nessa tal vizinha

que entende de ervas e folhas

O marido captou um brilho

tímido nos olhos sempre nublados da mulher

ue se apressou em colocar

s panelas na mesa

Senhor Gama Vitorino

he disse que poderia fazer

chegar a carta pros meus alunos

uando a caravana passar

erto da colônia

velha

Sentado na cadeira mais baixa

Vitorino meteu o queixo dentro do prato

e sugou uma colherada do caldo barulhento

antes de resmungar

E essas pragas

lá tem nome? 
O bandeirante veio para a mesa

com o seu conjunto de pijama

verde-musgo

puxando a cadeira

Ora nem tudo tem nome

o senhor tem razão

Mas dar nome é uma missão importante

Nessa viagem o governador já batizou

umas duas colônias

que visitamos

Vitorino levantou os olhos

de cavalo chucro

om a boca metida na bolsa de feno

observou as mãos finas do homem

guardando as folhas dentro

o caderno

ocês sabem

alguns lugares

êm nome estrangeiro demais

E quisermos reconquistar

esse sertão para a pátria

o mapa tem que ser povoado

com nomes de índios e dos caboclos

que são os verdadeiros

brasileiros

Já sabem como

vai se chamar o herdeiro? 
A mulher esperou a primeira palavra de Vitorino engolindo o caldo com os olhos

congelados e a mão por baixo da mesa

alisando a barriga

Vitorino levantou o peito

deitado no prato fumegante

e tirou os cotovelos da mesa

Com o nariz

elevado sobre aquele homem de

gabinete

desafiou

E senhor por acaso viu

algum índio

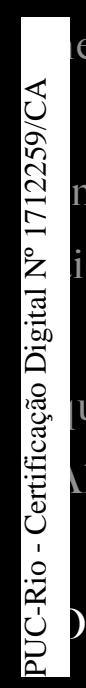

esse sertão?

ndio índio

inda não tive a chance

A não ser pelas histórias

ue os caboclos contam

liás

colono puxou as rédeas

da conversa que avançava

por um caminho pantanoso

O senhor não dê ouvidos

a esses morenos

que são cheios de

causos fantasiosos

O visitante deixou para depois

a história interrompida

e arregaçou as mangas

de flanela do pijama 
Pois muito pelo contrário

Se o governador me chamou

para escrever a história desta viagem

os causos dos caboclos

muito me interessam

Com o nível do queixo

acima do visitante

prestes a embalar as cordas vocais

o colono engoliu o fôlego

e soltou a voz frouxa de sempre

\section{Quer dizer então}

que o senhor é um escrivão?

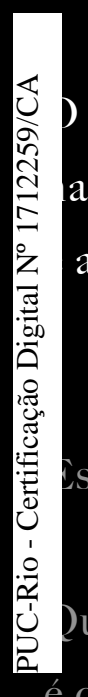

homem oficial largou o corpo

a cadeira

a risada fez eco

no céu da boca

é o desembargador glutão

que vive colado

no governador

O colono forçou uma risada fraca

de acompanhamento

mas olhava para o escritor

piscando frenético 
O senhor Boiteux

é o historiador da caravana

Certamente é tão confiável

quanto um escrivão de cartório

portanto não tem nada novo

pra contar

Muito menos aquele maldito papagaio

que perturbou o meu sono

todas as noites

no acampamento

Agora era o casal de colonos

que pareciam duas galinhas

olhando para um escritor

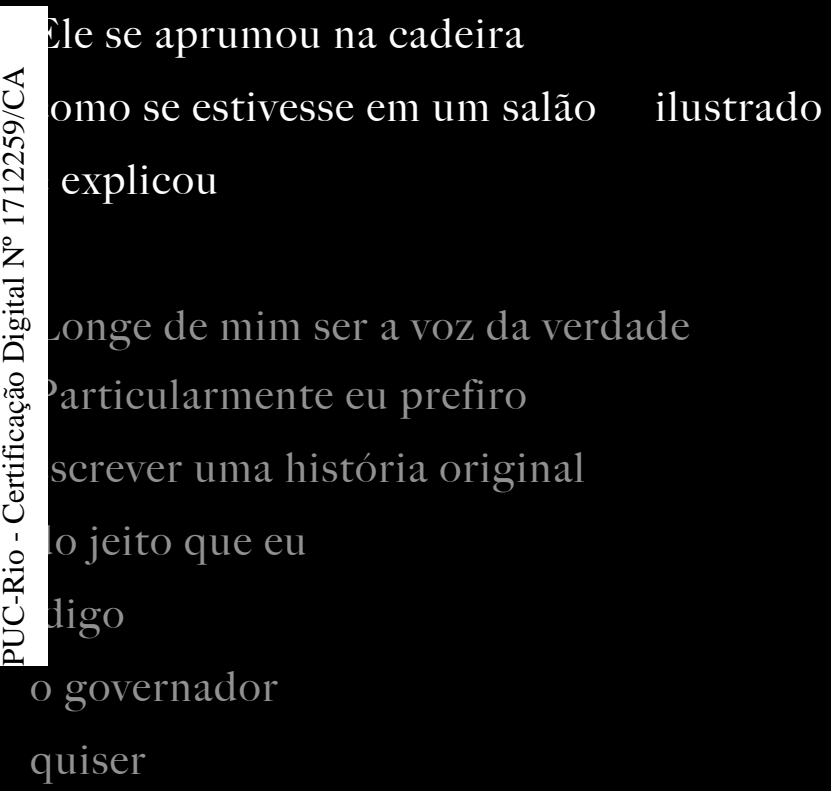




\section{$8.92 \mathrm{O}$ baile da onça pintada}

Avô Ino tapava os ouvidos

a cada buraco que Casemiro abria

no muro

com a furadeira

rangendo

A bengala do avô

não parava de socar

o chão

até que o empregado

não terminasse de pitar

o fumo de palha

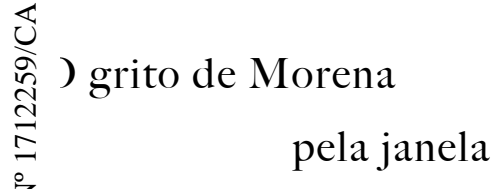

avisando do plantão da invasão

irou os olhos de Avô Vitório

las roupas largas

e sujas de terra

jue Casemiro herdava

L le Pai Vitório

$\mathrm{Na}$ cozinha

a voz abafada do locutor

saía do rádio

e a panela de pressão

chiava forte 
III A prefeitura recebeu ontem uma carta aberta enviada pelo grupo de índios que invadiu a praça da cidade O comunicado alerta que a suspensão da decisão judicial anunciada pelo prefeito aos moradores não é verdadeira e que a demarcação será realizada pelo próprio grupo Em busca de apoio na capital o prefeito afirma ter conseguido reforços do governo do estado e que as 40 famílias de moradores estão dispostas a resistir à demarcação III

O telefone tocou

e Vó Alma levantou da cadeira

ao lado do fogão de ferro

De onde observava

disfarçada

as mãos morenas

da empregada

passeando na despensa

abrindo a geladeira

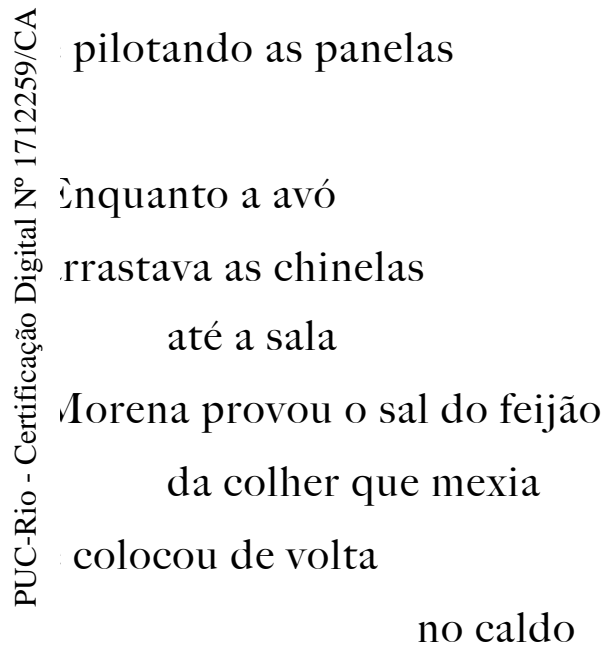

Os gritos de Pai Vitório

eram tão altos

que Vó Alma afastou

o aparelho da orelha

Com o primeiro silêncio

do outro lado da linha

ela tentou explicar 
Não é que a barriga dela

encolheu

totalmente

Mas um pouco

talvez

era inchaço

Vó Alma segurava o alto-falante

do telefone com as duas mãos

pequenas

De longe parecia uma

criança velha

com o os olhos

emburacando

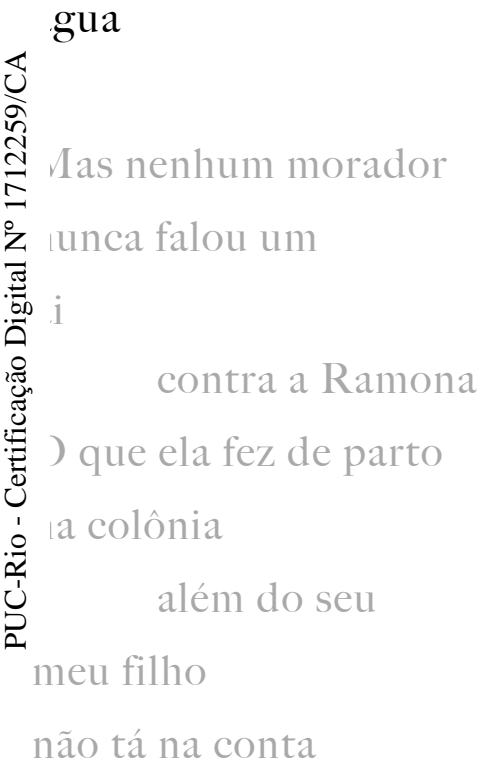

da cidade

Já a Clara

você sabe

essa história

de cor 
Morena diminuiu as bocas

do fogão

e se acercou

com vassoura

e pazinha preparadas

Vó Alma colocou no gancho

$o$ alto-falante

que cobria a orelha miúda

E ficou paralisada

ao lado da mesinha

enquanto as migalhas

caíam por baixo

da saia

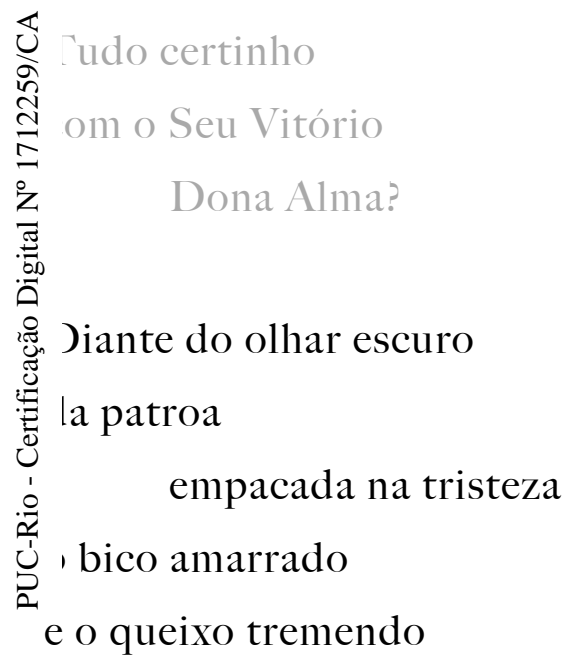

Morena fez dos farelos

espalhados

ao redor de Vó Alma

uma pequena

montanha

A voz saiu quebradiça

igual a casca do gelo fino 
Ele pediu pra levar

a Clara num doutor

\section{de verdade}

\section{Vai dar jeito}

de entregar o carregamento

em outro armazém

E volta

\section{voando}

\section{pra cuidar}

do filho dele

\section{direito}

Morena colocou a vó

de volta na cadeira

riste igual um camelo

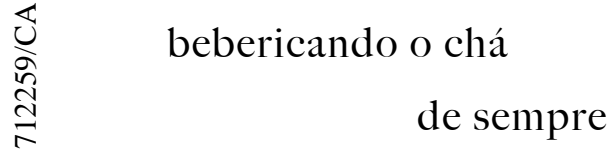

1 montanha de migalhas

胥 que transbordava da pazinha

Morena guardou em um pote

نَ

a despensa

Tudo normal nas ruas da cidade

os fregueses do Seu Klein

saíam com sacolas carregadas

E a praia de Copacana ensolarada

no alto

Na praça

os índios jogavam bola

cercados

pelos carros da polícia

nas esquinas 
Os policiais fardados circulavam

com seus pistolões e antenas

de longo alcance

O Judas do bar

ao lado da igreja

acompanhava a partida

as traves do gol

com latinhas de refrigerante

\section{Comentou}

com o vendedor de bergamotas

enquanto a rainha da cidade

sem o vestido nem as luvas compridas

o penteado desarmado

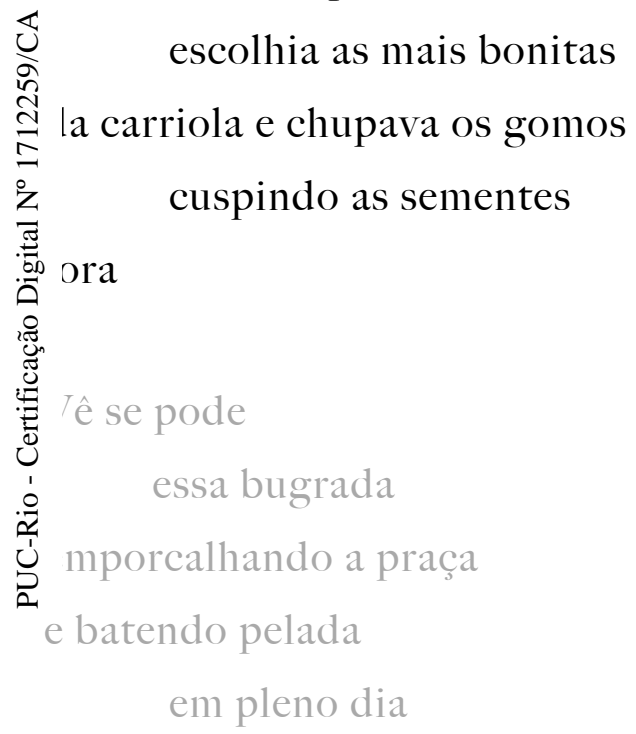

de semana

Depois ainda

querem

ser chamados

de índio

No balneário as torneiras

da bica continuavam fechadas 
As águas quentes das piscinas

$$
\text { paradas }
$$

sem turista à vista

O parque florestal igual

$$
\text { um deserto verde }
$$

Coloquei os dentes de alho

nos bolsos

$$
\text { e fiz um novo caminho }
$$

pra catar folhas

novas

Tirei o binóculos

detrás da moita alta

$$
\begin{aligned}
& \text { ङু } 1 \text { Rádio Tupi chiava } \\
& \stackrel{0}{Z} \text { dentro da cabana } \\
& \text { 莺 Uas nenhum sinal da onça } \\
& \text { 哭 intada }
\end{aligned}
$$$$
\text { Ũ }
$$

Pernilongos do tamanho de besouros

rodeavam as minhas bochechas

redondas

No meio

dessa guerra sangrenta

passos se aproximaram

quebrando gravetos e folhas secas 
Camarada Espingarda tinha razão

Quem vinha andando

era um caboclo

$$
\text { taludo }
$$

de costas largas

iguais as balsas

do rio barrento

Tinha uma cruz pontuda

de Jesus Cristo

desenhada no muque

e veios saltados

nos braços

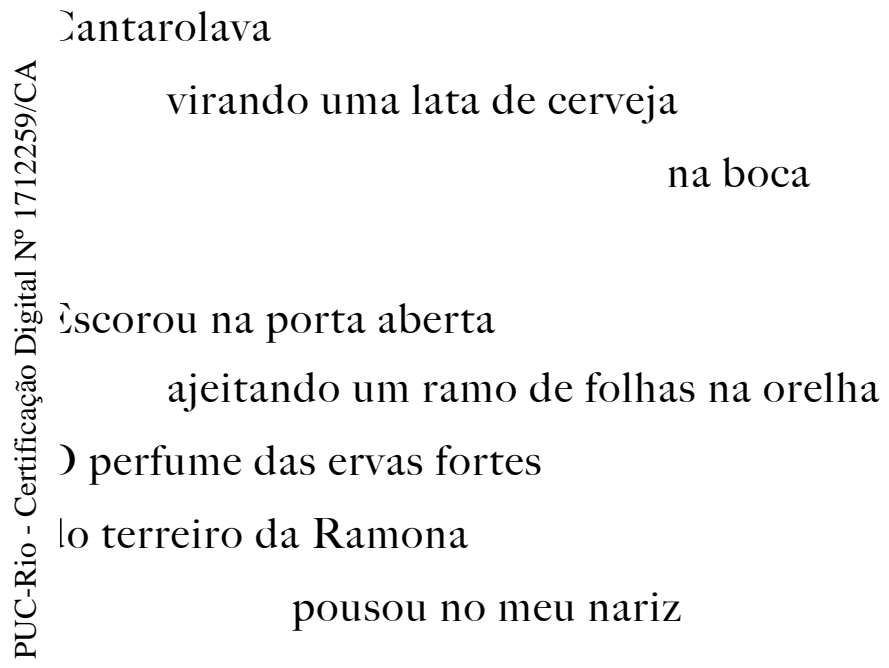

\section{Xiuuuu}

Ele chamou

com a mão na cintura da calça

de brim

Os tênis brancos não tinham

nenhuma mancha

de terra

sequer 
Quando ele entrou

no escuro da cabana

as gargalhadas da onça

fizeram eco

nas paredes

\section{$((((((()))))))$}

O volume do rádio subiu

e as vozes aumentaram

misturando com o chiado

O braço comprido

apareceu ajeitando a cabeleira

solta

$\begin{array}{ll}\text { ปั } & \\ \text { ปิ } & \text { As ombros pulseiras e os penduricalhos }\end{array}$

correndo

I fumaça do cigarro fez um risco

pra fora da janela

desmanchou no ar

峁

A pedra do anel amarelado

parecia um olho de gato

do mato

contra o sol

O caboclo

chegou perto

com o sorriso branco

a boca aberta mascando chicletes

e os cabelos brilhosos

de gel 
Atracados

um no outro

línguas estaladas

os corpos se amassando

gaitadas e gaitadas

Ele colou

no corpão da onça pintada aos pinotes

Os ombros sacudindo

no ritmo das marchinhas alemãs

que tocavam nos bailões

do Municipal

\section{foró-foró}

om fom fom fom

ป

Igual Morena

[uando dançava

agarrada nos morenos dela

varrendo a quadra

inteira

A banda Cosmos

Express

botando fogo no palco

e o gelo seco escorrendo

pelo salão

foró-foró

fom fom fom fom

Os dois varriam

a cabana

de uma ponta

a outra 
Quando o baile

terminou

a música do rádio

batia

nas taquaras da cabana

sem sinal dos dançarinos

na pista

Guardei o binóculos

na maleta

Escorreguei o olho

pela janela

acostumando a vista

ao escuro

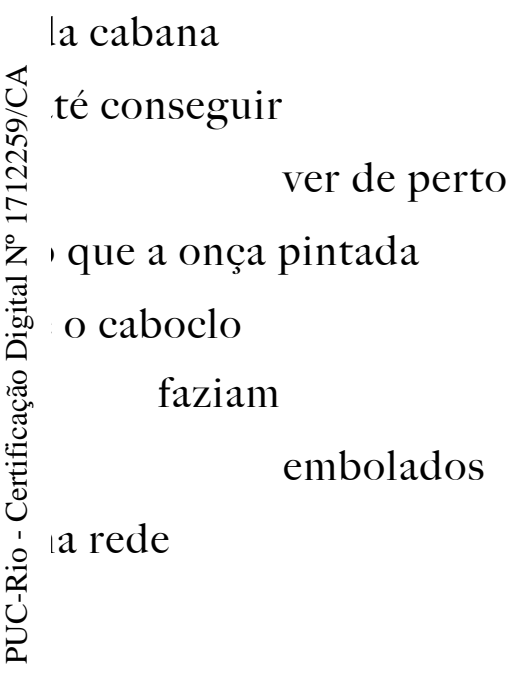




\section{Nota 8}

De volta aos corredores da universidade, Arlene sugeriu que uma forma de me aproximar da história dos Kaiang de Iraí seria através dos agentes do CIMI, um órgão ligado à igreja católica e com uma longa trajetória de trabalho junto aos povos indígenas. Entrei em contato com a unidade do Rio Grande do Sul, onde certamente haveria algum tipo de arquivo sobre o episódio da retomada de terras dos Kaigang. Caso não fosse possível uma incursão na aldeia, poderia ter acesso aos registros oficiais do caso. Há dias não recebia mensagens de Andreza. Escrevi a ela para saber sobre o estado de saúde do senhor indígena. Ela me respondeu apenas 3 dias depois, com muitos pedidos de desculpa. Tio Salvador havia ficado de cama por conta dos efeitos da quimioterapia e demorou a visitar seu amigo Índio. Quando finalmente chegou na cabana, descobriu que a febre prolongada ra, na verdade, sintoma de uma catapora.

Recebi uma mensagem de Luiz Carlos, o artesão de cadernos. A essas alturas, minha oleção já contava com uma boa série de folhas. Ele estava me convidando para uma festa o centro religioso Ilé Asè Aféfé t'Oyá, uma casa de encantaria. Mais surpreendente que o onvite foi a descoberta de um lugar deste tipo no Sul do Brasil. Uma casa de encantaria ra surpreendente em vários sentidos. Primeiramente por ser uma expressão religiosa afromeríndia das mais raras e antigas, praticamente restrita à região Norte do país, no Maranhão. E ainda assim, pelo fato raríssimo de uma casa dedicada a esse tipo de culto. Diferente da umbanda e do canbomblé, que realizam suas práticas em assentamentos, centros e barracões, as manifestações dos chamados encantados - os radicais caboclos mencionados por Luiz Antonio Simas na invenção do conceito - costuma acontecer nas ruas, sobretudo nas festas populares, as chamadas canjiras dos encantados. A lembrança de que todos os caboclos da encantaria eram conhecidos pela denominação exclusiva de caboclos, a despeito dos seus nomes individuais, agora surgia acompanhada de um paralelo. $\mathrm{O}$ de que os caboclos do Oeste catarinense, enquanto grupo étnico, também se manifestavam ao estilo dos encantados. Transitando livremente pelos nomes europeus e pelas peles brancas, como meu xará Luiz Henrique e o massagista Neuci. 


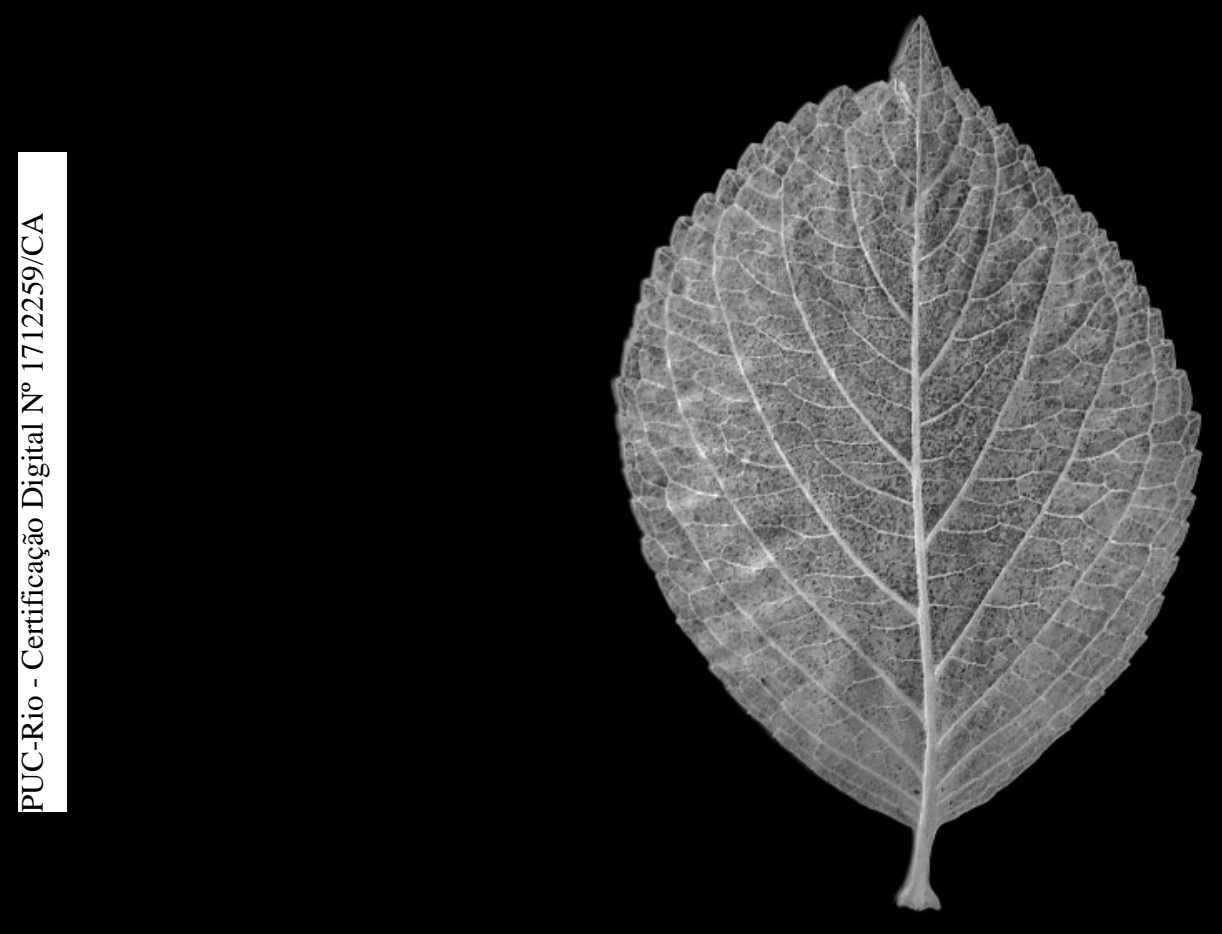

$-9=$ 


\subsection{O sonho do escritor}

Há dias que o escritor não deitava as costas

em um colchão que afundava

Além do pelego afofado pelas mãos de Alma

tinha dois travesseiro de penas de pato

e uma lamparina só sua

para organizar as notas da viagem

no caderno de couro

No dia seguinte pediria a Vitorino

que o levasse até o telégrafo

O editor do periódico República

ão recebia notícias da caravana

desde que entraram nas picadas da floresta

Recostado na cama com o corpo mole

ascunhava mais uma crônica

no caderno aberto sobre o colo

chá de boldo adoçado esfriando ao lado

Ios leitores que nos acompanham

nesta aventurosa viagem pelo sertão esquecido

peço desculpas em nome da caravana

do governador Adolpho Konder pelo sumiço

A caneta deslizou da linha

riscando a folha branca ao meio

até a mão pender para o lado 
Enquanto a respiração cavernosa

ressoava pela casa

cavava um buraco

por dentro dos pensamentos

que se debatiam como peixes

fora da água

Quando chegou

no fundo do sono

o desfile já havia começado

O carro alegórico de muitos andares

andava no meio da avenida luxuoso

Os bandeirantes vestiam capas de lantejoulas

e chapéus forrados de cetim

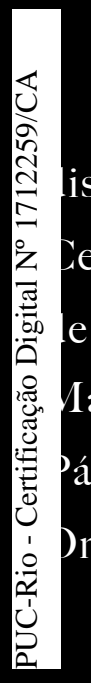

Carabinas envenenadas de brilho nas mãos

Batiam continência das várias clareiras

istribuídas pelo enorme esqueleto metálico

Tercadas por árvores nativas

e todas as espécies esculpidas no isopor

Iacacos mecânicos comiam bananas

ássaros piavam agudos elétricos

nças abriam

e fechavam a bocarra

Da vasta estrutura verde

que seguia em frente balançando

pela avenida

despontavam pequenas casas de colonos

Os casais com pencas de filhos

loiros como espigas de milho

abanavam faceiros das janelas

Coberto pelos adereços

era Senhor Leintz

quem pilotava o carro disfarçado

da cabine 
A ala de caboclos ia na dianteira abrindo o caminho ao som de um batuque muito original

Um samba com letra cantada sem ponto nem vírgula contando causos do povo igual um enredo de romance

O policial da caravana vigiava o bloco barulhento

ordenando que dobrassem os joelhos

ao som do tambor

$$
((((((()))))))
$$

Ias os morenos cantavam

ada vez mais alto

com as mãos pra cima

s bundas soltas

s seios livres

mbigos de fora

rrastando o pés descalços no asfalto

maior de todas alegorias

vinha séria e firme

vencendo os sacolejos do tablado mais alto

Uma réplica colossal

do bandeirante-mor montado no seu cavalo

e chapéu suavemente inclinado

Aos pés da escultura

em tamanho menor

o próprio governador fazia um troféu

com as mãos unidas pro alto 
O fiel historiador oficial

vestindo um manto de imperador que sobrava no chão

e seu papagaio estimado

também ganhavam destaque

embora ficassem ofuscados pela decoração

de livros gigantes

O cortejo chegou na praça central

e a caboclada ocupou os gramados

em torno do pedestal

Bandeirantes e colonos

despencaram das alegorias ao seu encontro

Lá estavam todos bailando

marchinhas sambas e maxixes

ritos gaitadas e risos descontrolados

ob uma chuva de folhas verdes e penas

Ds funcionários do diretor baixaram

escultura do último andar

e passaram carregando

descomunal governador no meio do povo

em transe

De trás das árvores enfileiradas na calçada

surge um índio paramentado

O selvagem carrega ao mesmo tempo

dentes de onça pendurados no peito

distintivos militares no braço

e a espingarda carregada

O caboclo que guiou a caravana dos bandeirantes pela floresta

no meio da pequena multidão

fala ao ouvido do escritor

que tudo ouve 
É esse o tal fantasma

do índio famoso

de nome mais conhecido

nesse sertão

Os batuques silenciaram

e os foliões abriram passagem

para que o índio chegasse até o chefe do estado de ferro fundido

O único som que se ouvia nessa hora

saía pelo bico do infernal papagaio

Um cacarejo esquisito

parecido com aquele

que vinha do galinheiro de Vitorino

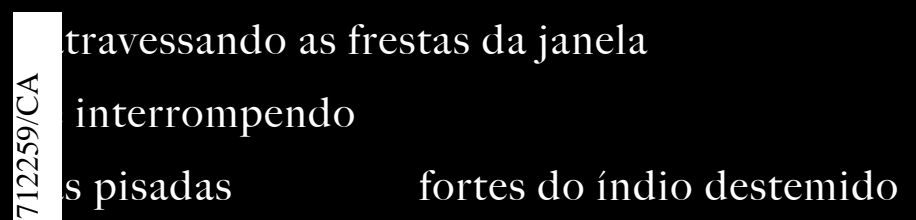

Intes do escritor se engasgar

om o próprio ronco cavernoso

maldito papagaio repetiu

como repetia nas noites do acampamento

\section{inça!}

E onça!

É onça!

até o bandeirante saltar

para fora do colchão macio

e procurar a pistola aos gritos

É onça

Vitorino

Vitorino é onça!

Onça Vitorino! 
9.92 A onça na jaula

Antes dos índios

invadirem a cidade

o Circo dos Macacos Ciganos

erguia a lona vermelha

no meio da praça

durante as noites

de calor

Avô Ino deixou a vó

nas banheiras termais do balneário

pra melhorar dos nervos

త్

me levou visitar o acampamento

da trupe

lurante a sessão

de hidromassagem

vaquela hora

antes do almoço

, circo não era o mesmo

dos espetáculos com o letreiro

iluminado

Os trajes coloridos

estavam estendidos

num varal comprido

embaixo do sol 
As fantasias as máscaras e as perucas

pareciam galinhas

de pescoço torcido

que Vó Alma pendurava no galho

pelas patas

antes de amolecer as penas

na água fervente

O barbudo

que soprava fumaça

doce

deitado na rede

No chão

rodelas de salame

fritavam na grelha

(1)

lisse que os bichos enjaulados

icavam depois dos carros

$\dot{z}$ maiores

das caixas de som

;ó não recomendava

mexer com os macacos

ป́ hora da refeição

E riu

com a barriga cabeluda

tremelicando

e o dente de ouro

saltando na gengiva

Paramos em frente

à jaula da famosa Iracema

Esparramada no tablado

emporcalhado

como se fosse dona do circo

inteiro 
Ela levantou

o corpo pintado

e começou a andar

de um lado pro outro

naquela caixa apertada

Pedi ao Avô Ino

que me levantasse do chão

pra ficar da altura dela

Onça Iracema parou

e cruzou os olhos amarelos

riscados com os meus

As pepitas de ouro

sujo

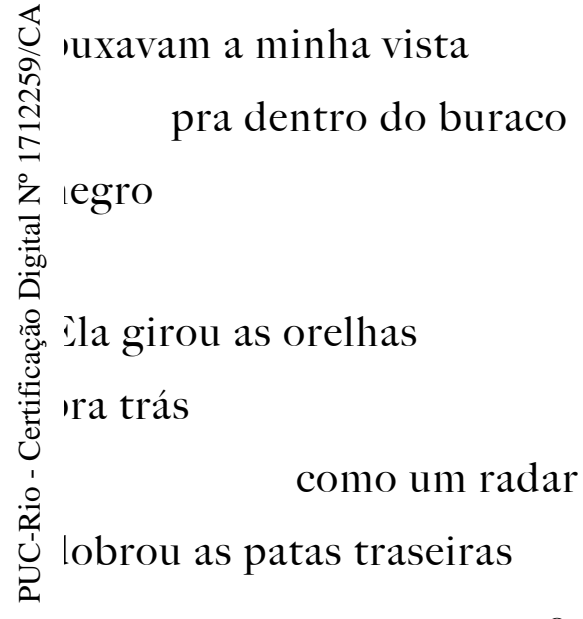

o rabo esticado

$\mathrm{e}$

\section{$((((((()))))))$}

a cabeçona chocou

contra as grades

esmagada

A pata larga passou pela fresta

e as unhas pretas

fizeram vento

na nossa carne 
Ela escancarava a boca

arregaçando a bigodeira

e urrava fundo

com os dentes pontudos

arreganhados

O bafo medonho

fez o sangue descer

gelado pela espinha

e uma cachoeira

quente

escorreu nas pernas

O avô deu um pulo

ssustado

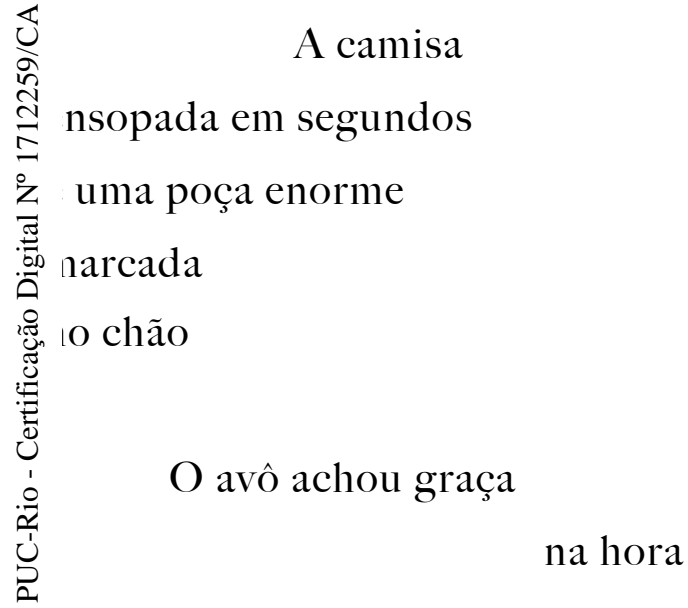

mas depois

quando perguntei

como o dono do circo sabia

que Iracema não era um caboclo

virado na onça

ele fechou a cara

A partir daquele dia

Morena ficou proibida

de contar histórias antes de dormir

na cama de

baixo 
Nunca mais

ouvi os causos

$$
\text { do Tio Salvador }
$$

Nem as sereias

que afogavam os balseiros

nas corredeiras do rio Uruguai

Nem as bruxas

que sobrevoavam os parreirais

bebendo os vinhos dos colonos

peladas

Foi então

que Morena disse

pra comer sementes

[ue as histórias chegariam
eito bandos de pássaros
nos galhos 


\section{Nota 9}

Peguei um novo ônibus para Caibi e cheguei na sexta-feira à noite, quando Andreza trocava de turno com outra ajudante. Na primeira oportunidade em que ficamos sozinhos, ela me disse que Tio Salvador havia levado o senhor indígena ao posto de saúde. Ele já estava medicado e em repouso. Não sei exatamente o motivo pelo qual nos comunicávamos daquela maneira secreta, pelos cantos da casa. Talvez para não causar ciúmes na minha avó. Imediatamente, a suposição me fez pensar que Andreza estava vendo em mim algo que eu não tinha percebido. Um pouco tímida, como sempre, ela me deu um presente. Um potinho de plástico que continha vários anéis. Eram anéis de coco, que havia ganhado do seu cunhado indígena. Perguntei se não sentiria falta deles. Ela respondeu que não gostava

e usar aqueles artesanatos nos dedos. "Fico agoniada, me sinto presa".

alvez não tivesse experimentado a temporalidade tão diferente em que vivem meus avós, e não estivesse esperando pelo senhor indígena que povoava a minha imaginação. Vó Irma assava horas deitada no sofá e depois vigiava a preparação do almoço, até deitar-se ovamente. Vô Carlos assistia à televisão e caminhava com o andador em volta da casa, om a ajuda de Andreza. Desde que a degeneração começou a avançar, ele passou a trocar is tempos com frequência. Antes de dormir, então, pedia a minha tia que checasse se as acas e as galinhas estavam bem protegidas no quintal, como na casa antiga da Linha São orge. E se o cavalo, em vez do carro, estava bem abrigado em caso de chuva. Dentre todos os gestos inconsciente que observava em meu avô, um deles me intrigava mais. Todos os dias, depois de analisar os próprios pés, ele dizia haver contraído bicho-de-pé. Era como se a lembrança de trabalhar na terra durante muitos anos estivesse marcada no corpo, como se a memória ficasse latente naqueles pés que já viviam há muito tempo resguardados dos trabalhos na roça. Exatamente do mesmo modo como a minha memória de menino se revelou através das marcas na cintura. A única solução que também se repetia para o avô, dia a dia, era uma encenação. Então Andreza tirava as meias dele e fingia extrair o inseto da sola dos pés com uma agulha. 
No início daquela tarde, depois do cochilo do meu avô, Andreza me procurou para dizer que estava preocupada. Tio Salvador havia levado o senhor indígena às pressas para o hospital de Chapecó. O estado de saúde dele havia se agravado muito. Tudo indicava que o diagnóstico da catapora estava errado. Ofereci ajuda, dispondo-me a voltar para Chapecó e ir até o hospital encontrá-los. Andreza resistiu, dizendo que Tio Salvador e sua mulher estavam do lado de fora da UTI. O restante do dia foi de espera. Eu e Andreza não fizemos nada além de trocar olhares aflitos enquanto jogávamos baralho com os meus avós. Quando ela fez a troca de turno, prometeu me manter informado. Durante o jantar com meus avós, já pensava no plano do dia seguinte. Acordaria cedo e tomaria o ônibus de volta a Chapecó. Minha ideia era ir direto ao hospital para conseguir informações diretamente com Tio Salvador. Era início da madrugada e eu já havia sido vencido pelo sono quando chegou a notícia de Andreza. O senhor indígena havia morrido. Fiquei em estado de choque, afetado pela paradoxal sensação de haver perdido uma pessoa de carne e osso, que -té então era apenas uma presença invisível, um corpo imaginário. Enquanto eu tentava ssimilar o acontecido, Andreza falava de detalhes que tornavam a morte dele ainda mais ramática. Sua cabana havia sido queimada pelos vizinhos e eu sequer desconfiava que o enhor indígena era hostilizado pelos caboclos do bairro da Gruta. E o pior de tudo era ue ele provavelmente seria enterrado no cemitério de Chapecó como indigente, já que não inha documentos e nem parentes legais. Andreza estava tão abalada quanto eu. Sua voz mbargada, na mensagem de áudio, não parava de pedir desculpas por ter falhado em fazer nosso encontro acontecer. 

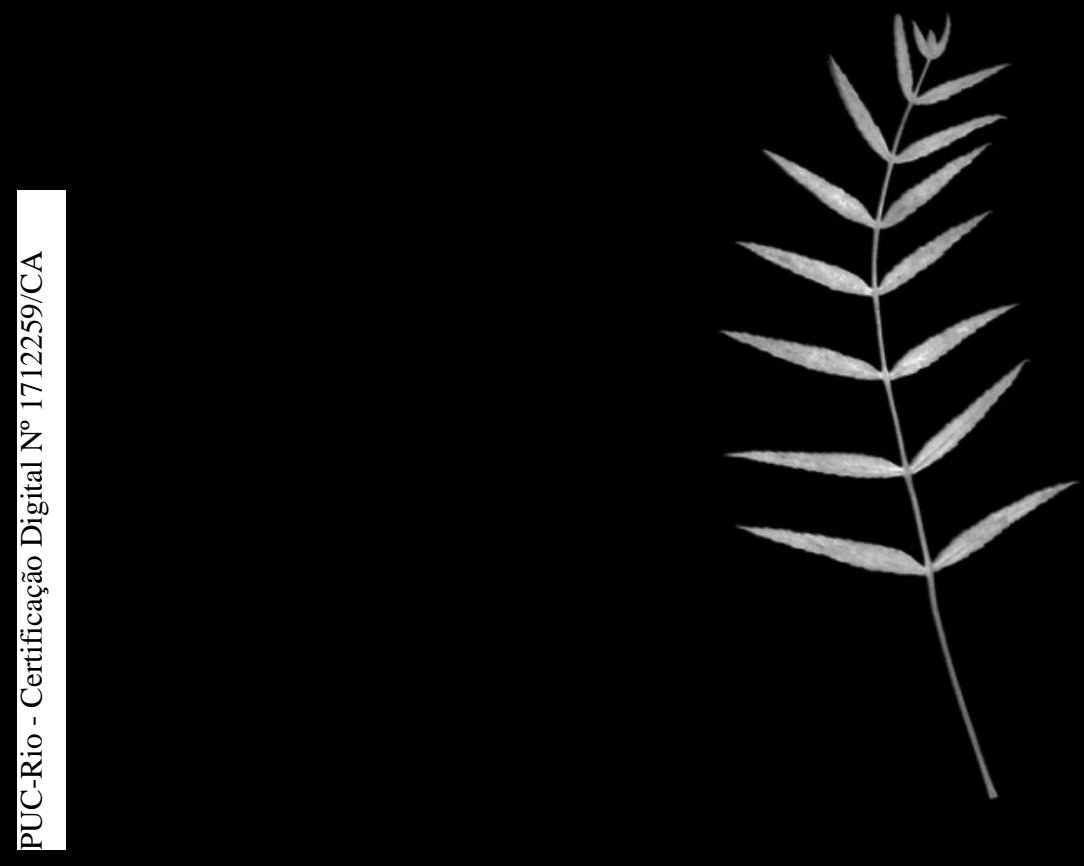

- $\mathrm{IO}-$ 


\section{IO.29 Um índio chamado Vitorino}

Agarrada ao travesseiro

ouvindo os roncos do escritor

ressoando novamente pelo corredor

a voz de Alma surge no escuro do quarto

Agora sim

Capotou o pobre

Misturei valeriana com cidreira

Nem sei se fiz direito

mas com aqueles olhos estalados

ão ia dormir nunca o coitado

itorino que também tinha os olhos pregados

as sombras do teto depois do susto

rotou no silêncio

Demorei pra entender

o que ele queria dizer

aguejando daquele jeito

E a pistola rodando

na mão dele?

Minha nossa

No final das contas

foi graças ao tal historiador

que o pior não aconteceu

Imagina se ele

não tivesse tirado

as balas da arma? 
Alma se aproxima um pouco

do marido

Mas e agora

será que era onça mesmo?

Vitorino sentiu a respiração da mulher

encostar no seu rosto

ela que sempre fica virada

para o lado de fora da cama

Ora mulher

você acha mesmo

que uma onça ia perseguir

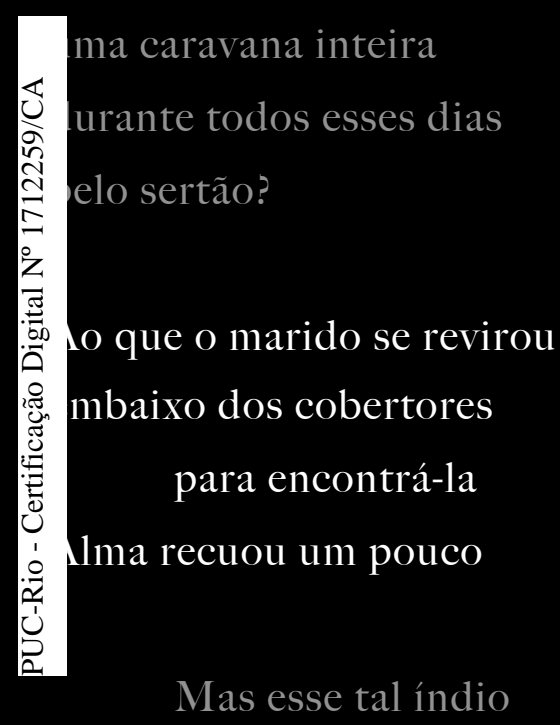

existiu mesmo, né?

Isso é

Um índio com o nome

igual ao seu

Deus meu

É Vitorino de quê

mesmo? 
Vitorino reconhecia os voleios

que a mulher dava para desviar

dos seus braços

e voltou a barriga para o teto

Condá

Vitorino Condá

E será que ele não

aparece mesmo pelas matas

assombrando essa gente

maioral?

Meu pai aparece

com o peito lastimado

os sonhos

às vezes

itorino recolheu os pés

que ficavam de fora do colchão

se recolheu em concha

o seu lado

onho é diferente

Não ouviu o que ele disse?

Foi o tal caboclo que trabalhou

de guia da caravana

que veio com essa história

Deve ter dado

umas boas gaitadas

com esses homem

tudo armado

ouvindo miado de onça

e sentindo a catinga do bicho

sem nunca ter visto um

de verdade 
A mulher arriscou detrás

da barreira que tinha feito entre eles

com travesseiro

Podem falar o que for

desses moreno

Mas são bons contadores

de causo

Eu que não me fio

nesses causo batido

Conformado com a fronteira

dos lençóis

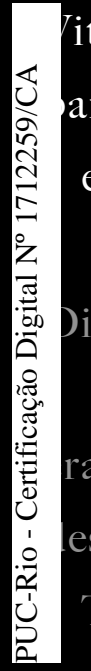

torino se virou

ara o lado contrário

e continuou

matando onça

pros fazendeiro

A mulher se rendeu

e cutucou a montanha

para saber o resto do causo

E dali? 
Dali nada

diz que descobriu

que era parente delas

O serviço sujo

pesou na consciência

e se bandeou

pra dentro da floresta

Mas então homem!

Se caboclo vira no bicho

índio não pode

virar onça

também?

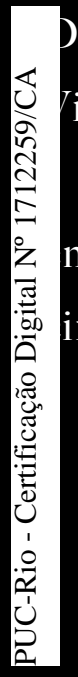

o seu lado da cama

itorino ficou olhando as palavras da mulher

pairando no escuro

nquanto o ronco do escritor

irculava pela casa 
I0.92 A barriga de Mãe Clara

Mãe Clara deitou na maca

esbaforida

de subir os degraus

da escadinha

e arregaçou a blusa

O doutor começou tocando

nas beiradas da barrigona

que tinha baixado

um palmo

Mãe Clara havia secado

s sobras das bochechas

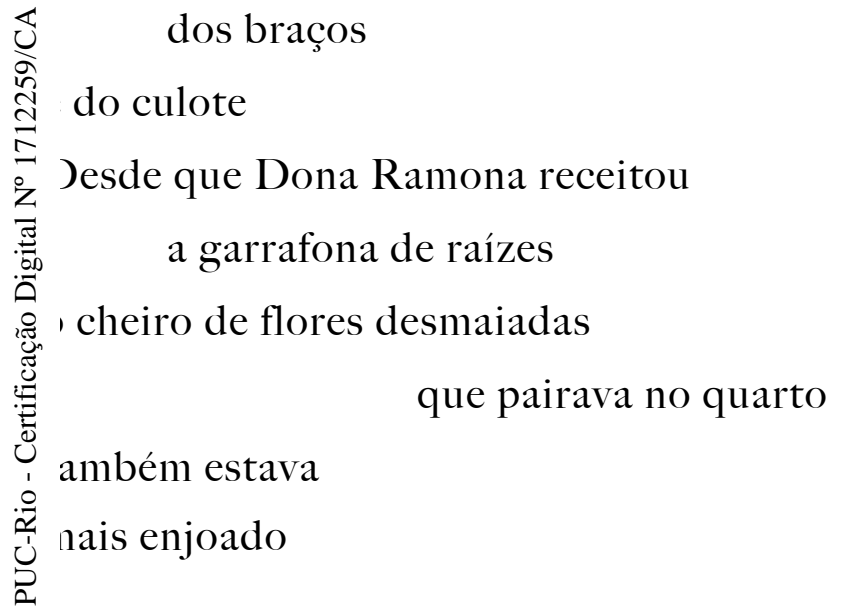

Eu segurava na mão dela

a aliança dançando no dedo

Será

que o irmãozinho

vai querer

sair

mais cedo

pra brincar? 
O doutor leu meus pensamentos

igual a Dona Ramona

e pediu pra Mãe Clara

não fazer esforço

enquanto apertava mais

forte nas laterais

A tosse de Avô Ino ecoava nos azulejos do consultório

$$
((((((()))))))
$$

Pegou friagem

Seu Vitorino?

) avô dobrava o lenço

ญ m quadradinhos

apertados com a terra

scondida

.

Tou mandar

m expectorante na receita

prosenhor

em um índio

de idade avançada

no quarto ao lado

que também tá resfriado

É esse vento

Imagina

dormir dentro daquelas

barracas com lona

furada

O senhor

tem que se cuidar

também 
Avô Ino concordava

com a cabeça

mas o doutor não podia ver

atrás das lentes escurecidas

os olhos inchados

das noites em claro

fazendo ronda

no terreiro

Logo eles vão

ter que voltar pro mato

Não é o primeiro

deles que adoece

No jornal já deu até

ule o movimento

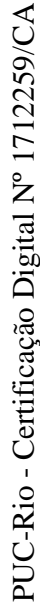

iem demora

prefeito volta

com reforço do

stado

) doutor puxou a blusa de Mãe Clara

obrindo a barriga

deu batidinhas no bebê

e apertou o botão do telefone

assim que ela entrou

no banheiro

No porta-retrato em cima da mesa

o doutor usava um chapéu preto

e quadrado

como se fosse um rei

do passado 
A enfermeira entrou no consultório

e estacionou a cadeira de rodas

ao lado da maca

O doutor disse

que eu seria o motorista de Mãe Clara

até o outro quarto

no final do corredor

enquanto ele conversava

com Avô Ino

sozinho

Mãe Clara já tinha apagado

quando a enfermeira colocou o soro

no alto

ila trouxe polenta mole

$\mathbb{S}$ m caldo ralo igual ao de Vó Alma
com gelatina

ligou a televisão

)epois de beber

o caldo todo e engolir

polenta com gelatina

Ù 'erguntei

se o bebê de Mãe Clara

ia sair tão grande

como Pai Vitório

apostava

Os olhos pintados da enfermeira

com sobrancelhas tatuadas

pararam na barriga de Mãe Clara

e voltaram pra bandeja vazia

com a maquiagem toda

borrada 


\section{Nota Io}

Pela manhã, escrevi um email a Arlene contando sobre a morte do senhor indígena. Depois do café, enquanto tomava sol com meu avô no quintal, recebi a mensagem de uma amiga de infância, Eloísa. Ela morava na casa ao lado da minha, separada apenas por um muro. Exatamente de onde me escrevia naquele momento, depois de ver uma foto do quintal que eu tinha postado nas redes sociais. Em alguns minutos, ela bateu palmas no portão trazendo um saquinho de café e um bolo. Eu e Êlo, como a chamava, frequentávamos juntos o jardim da casa amarela, que ficava no Bairro da Gruta. Perdemos totalmente o contato depois que saí da cidade, aos 6 anos de idade. Ela estava de volta à casa da família depois de haver se separado da namorada com quem morava em Porto Alegre. Diante dela depois de tanto tempo, surpreso por saber que tinha uma namorada, atentei para a emelhança dos nomes. Era como se no dela estivesse inscrita uma versão feminina do meu: iloísa. A associação veio junto de uma lembrança constrangida, das vezes em que os ossos colegas da casa amarela me chamavam justamente desta maneira: Luiz, Luiza, uizinha.

inquanto Eloísa girava a manivela do moedor antigo de café da sua avó, revivi um entimento familiar. Era a mesma admiração que sentia quando criança pelos seus gestos aasculinos, seus ombros fortes e o peito estufado. O contrário também devia acontecer aos Ihos dela, diante das minhas formas mais roliças e dos meus gestos mais delicados, motivo das provocações dos nossos colegas. Não por acaso foi com Êlo com quem costumava brincar dos jogos eróticos que encenam os casais adultos. E que, sem perceber, subvertiam os papéis de gênero. Enquanto eu via um namoradinho secreto na menina de gestos masculinos, ela podia ter a sua namoradinha com o menino de jeito afeminado. Assim, o reflexo projetado no nome de Eloísa me devolvia uma sensação antiga, já esquecida, daquilo que eu nem sabia quando menino. O meu desejo por outro modo de ser homem, entranhado no feminino. Não fosse o nosso reencontro, não teria me dado conta de algo ainda mais impressionante. Eloísa havia sido apagada da minha memória como a melhor amiga da infância. Meus pais costumavam contar, nos seus relatos sobre os tempos de Caibi, que eu havia deixado um melhor amigo para trás - em vez de uma amiga. Narrativa, esta, que eu havia assimilado sem me dar conta. Sem perceber que, talvez, eles já vissem a minha intimidade com o feminino com alguma resistência. Não consegui encontrar 
nenhum registro com a presença de Êlo naquela época. Na fotografia do desfile de 7 de setembro, quem aparece no seu lugar é o amigo escolhido pela família. Durante o longo café na cozinha da minha infância, tantas vezes frequentado por ela, contei a história sobre o senhor indígena. Êlo imediatamente se ofereceu para descobrir detalhes mais precisos daquele mistério. Começaria perguntando a sua mãe, que era ministra da igreja e conhecia praticamente todos os caboclos que moravam no bairro da Gruta. 


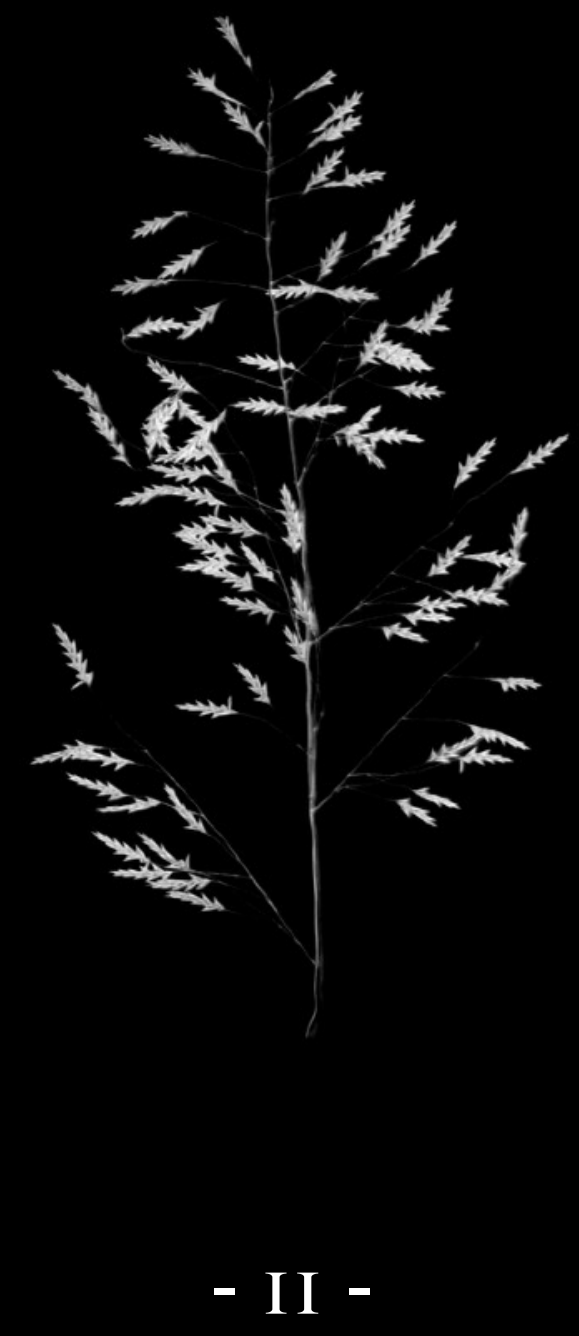




\section{II.29 O baile da colônia}

Vitorino chegou no clube recreativo ao lado da igreja

de botinas camisa abotoada até o pescoço

e braços dados com Alma

O som das sanfonas e das violas

vazava pelos janelões com as nuvens de fumo crioulo

Ao ver o casal paralisado na porta

cerimoniosos naqueles trajes de festa

o escritor veio chamá-los

com os pés serelepes

para sentarem na sua mesa

ogo que sentaram

enhor Gama atravessou o meio do salão

onde os primeiros casais dançavam acanhados

voltou como um torpedo

segurando um garrafão de cerveja

a fabriqueta do Seu Braun

itorino encheu o seu copo até a borda

e para a mulher apenas metade

Brindaram de longe com o escritor

que já pulara para a mesa ao lado

Parecia discutir algum assunto de discórdia

com o desembargador balofo

que o olhava com cara de planta

detrás dos óculos redondos

enquanto gesticulava acalorado

A cada golada que entornava

o colono sentia o pescoço asfixiado

naquele traje ensacado 
Aos poucos os pensamentos ficavam mais gasosos

e a cabeça acompanhava as melodias

cada vez mais ouriçadas

da banda no palco

A quantidade de dançarinos aumentava

como se um ímã os puxasse para o salão

Vitorino bateu o olho em Ramona e Salvador

agarrados no meio da agitação

arrastando o pé

Antes que atendesse ao impulso

dos joelhos

e puxasse Alma

que bebericava do copo igual um pássaro triste

as suas vestes escuras

escritor veio com os braços estendidos

edindo a licença do marido

ara ter a honra de dançar com a sua mulher

S olhos de Vitorino iam de um lado a outro do salão

sem querer ver

mão de Alma sobre o ombro do paletó

s dedos finos de escritor na sua cintura

O casal de caboclos corria a pista inteira

Salvador guiava o passo

como uma balsa cortando as ondas do rio Uruguai

Levava a mão de Ramona entrelaçada

os braços de leme aprumados

enquanto a mulher requebrava as ancas

que saltavam do vestido

O moreno tinha um estilo ousado

ao mesmo tempo que controlava da proa

rebolava e remexia a cintura

como nenhum homem fazia 
A cabeça liquefeita do colono

acompanhou o giro de pernas

com que o caboclo voltou para o meio

dos corpos saltitantes

Vitorino foi até a copa

e pediu mais um garrafão ao bodegueiro

Acenou de pronto

quando viu Senhor Leintz e o governador Konder

conversando ao lado do churrasco

escorrendo sangue na fogueira

E tentou de novo

Mas não foi reconhecido

uando sentou à mesa

bebendo o garrafão no bico

alvoroço tinha se alastrado

elo baile todo

im um coro inflado

todos cantavam o refrão

a canção que Vitorino não conhecia

Quando seus olhos turvos toparam

de novo com o casal risonho

múltiplas Almas dançavam

em um caleidoscópio de risadas

que o marido nunca recebia

Vitorino saltou da cadeira

pequena para tanto corpo

e arremeteu em direção ao casal

Chegou estabanado em cima dos dois

tentando frear o impulso tarde demais 
O escritor entregou as mãos da mulher prontamente

Mas Alma a cara assustada

protegendo a barriga com a mão

pediu um descanso

para as pernas desacostumadas

Com o sorriso desmontado

Vitorino puxou o braço da mulher com força

Ela deixou que ele colasse o corpo

no seu o rosto virado para o lado

Sem traquejo para conduzir a balsa

o marido tropeçava nas pernas duras da mulher

Uma e outra vez

Ité o sorriso voltar desesperado
o sangue queimar o rosto

Numa arrancada

evou o corpo sem alma da mulher

prensar em um casal de caboclos

lma se livrou dos braços compridos

e deixou Vitorino sozinho

o meio do salão

Os casais continuavam passando

sem disfarçar o olhar

para aquele homenzarrão

com as braços pendidos

Sem chão embaixo dos pés

e toda aquela raiva circulando por dentro

Vitorino buscou o casal de caboclos

e bateu no ombro do moreno 
A mulher do homem atiçado

acompanhava os olhos arregaçados do colono

pra cima dele

Tentava puxar pela camisa

para o canto do salão

pedindo calma no ouvido

Mas nada

Vitorino mirou naquele homem

e largou na sua direção

Ao ver aquele corpo enorme

desengonçado na sua reta

ao caboclo jogou a mulher para o lado

passando uma única

anda no colono

Titorino ainda tentou se agarrar no ar

antes do corpalhão estatelar no chão

Ima clareira se abriu no meio da pista de dança

quando o colono tonto pela queda

olhou para cima

caboclo que antes batia na sua cintura

ra agora um gigante

com a pistola apontada

para a sua testa

Os funcionários do diretor

caíram em cima do moreno

Vinte mãos

arrastaram o sujeito porta afora

enquanto a mulher ia gritando atrás 
O escritor oferecia a mão

recusada pelo colono

que levantou sozinho

debaixo do olhar de todos os colonos

e bandeirantes

Dentro daquele corpo tão grande

trançando as pernas

Vitorino se sentiu o menor dos homens

da colônia inteira 
II.92 O mijo da onça

O caminhão de Pai Vitório

estava estacionado na calçada

fazendo sombra

dentro de casa

Todo mundo no hospital

Morena

estava ajoelhada no canteiro das flores

mexendo na terra

enquanto Gegê perambulava pelo quintal

క

té a cabana

udo estranho

as ruas da cidade

mercado do Seu Klein

que abria até aos domingos

inha as portas fechadas

¿ 1 praça parecia a praia

de Copacabana

os moradores disputando espaço

pra ver o retorno do prefeito

da viagem à capital

Além dos carros

parados nas esquinas

as luzes da sirenes girando

caminhonetes da polícia

circulavam

com canos de fuzis

saindo pela janela 
Cheguei

na trilha do parque

engolindo ar

$\mathrm{O}$ bando de quero-queros

acompanhava do alto

o caminho novo

que as folhas

mostravam

O bambuzal dançava com o vento

o tronco de duas árvores

esfregaram

gemendo

Jetrás da moita alta

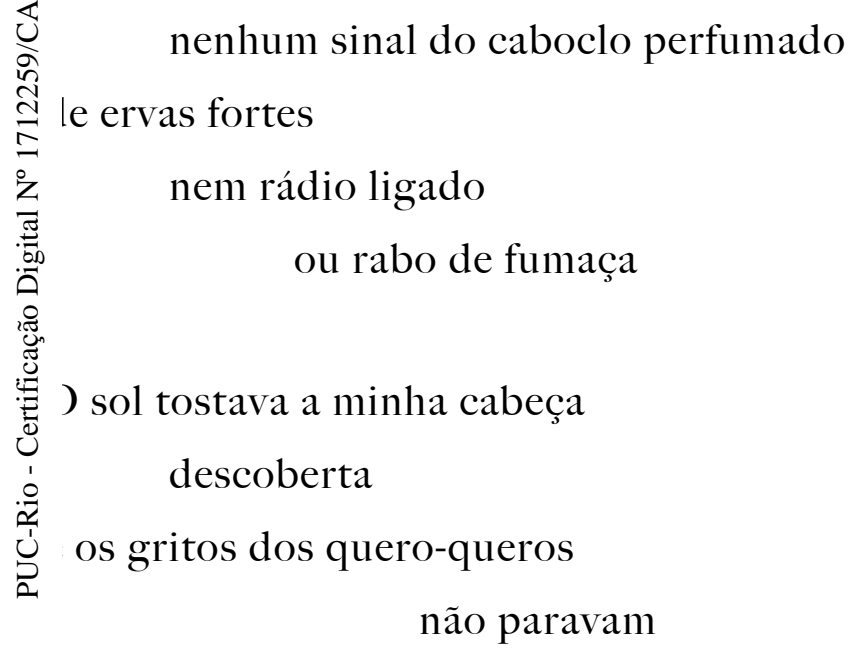

de desafiar

Fui com os passos altos

e leves até a cabana

desviando das folhas secas

e dos gravetos 
Da porta

tudo quieto e escuro

$$
\text { sem nenhuma }
$$

sombra de onça

$\mathrm{O}$ vento

que passava pela janela

não dava conta

de abanar a catinga de asa

misturada com o doce

de calda de pêssego

enjoado

Da rede

vinha um rosnado

um ronco tão alto

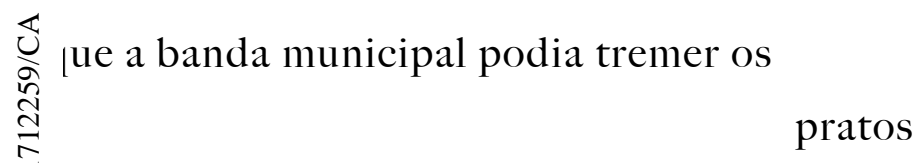

em despertar

o corpo grande e pesado

[ue esticava as cordas

roçava as franjas

o chão

2

Quando dei o primeiro

o segundo e terceiro

$$
\text { passo }
$$

esticando o pescoço

mais alto que os pratos

tremendo

os trompetes gritando

$$
\text { e os tambores batendo }
$$

juntos

foi o barulho do helicóptero

sobrevoando

a cidade 
Corri

disparado de volta

pra moita

Metido no meio das plantas

altas

rezei só com os lábios

juntando as técnicas de Vó Alma

e Dona Ramona

Fechei os olhos

pedindo que nenhuma cobra

estivesse escondida ali

no meio

pois desta vez

eu estava sem os dentes

le alho

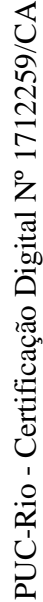

)s quero-queros gritavam mais forte

)s passos

rranharam o chão de terra

Juvi a garganta

raspar fundo

e puxar uma cusparada

barulhenta

pro lado

As pisadas fortes

aumentaram na minha direção

como se fosse um bote

certo

mas pararam

quietas 
Encolhido

das frestas do esconderijo

vi o corpalhão gigante

do tamanho de Avô Ino

Olhava pro alto

e pros lados

algum rastro da banda municipal

ou da aeronave

que havia perturbado

o seu sono

Com a cabeleira no rosto

os beiços vermelho

encarnado

os olhos pintados

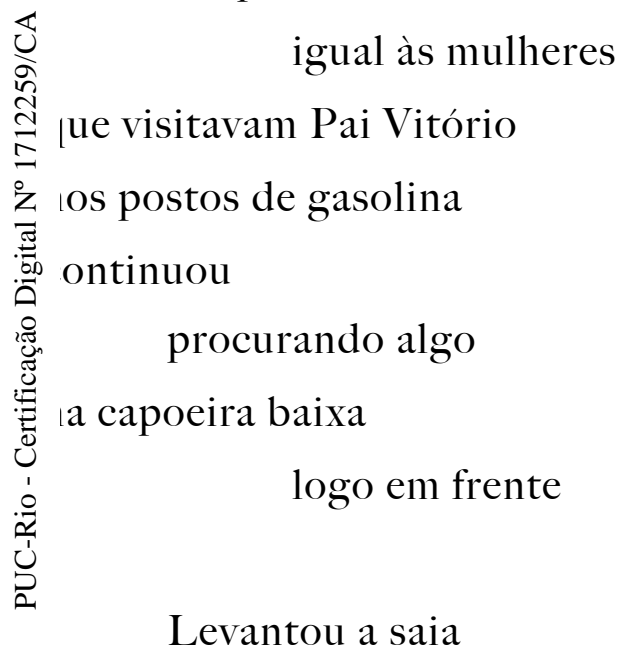

curta de pele

malhada e regou de pé

as folhas longe longe e comprido

com um barulho de jato

de mangueira igual

Morena esguichando a terra

seca do quintal

inventando chuva

em dia de 
De volta pra casa

Vó Alma estava ajoelhada no canteiro

onde Morena havia transplantado

as margaridas murchas

de Mãe Clara

No quarto

Pai Vitório estava ao lado da cama

com aquela cara de espantalho

quando dirigia pelas estradas

na madrugada

Mas dessa vez

os olhos de farol alto

no meio do rosto

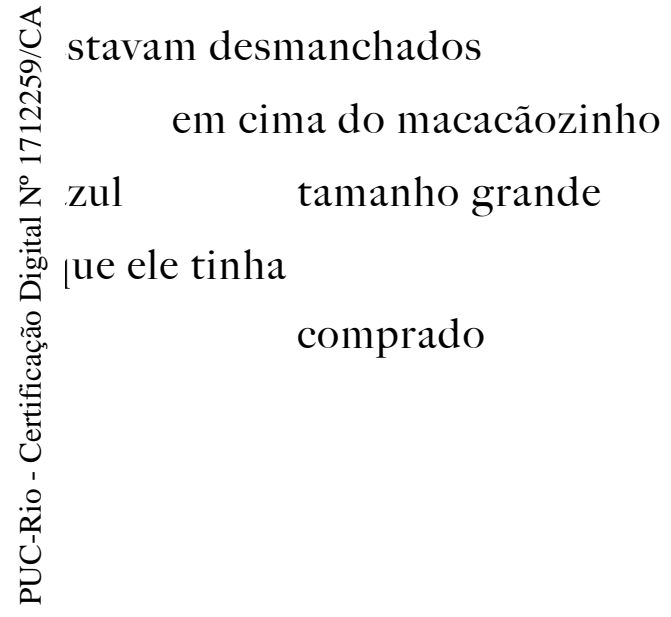




\section{Nota II}

Logo no início da semana combinei de encontrar Arlene na cafeteria da universidade. Os fatos daquela história intrigante não haviam terminado com a morte do senhor indígena. Nas conversas seguintes que tive com Andreza, já de volta a Chapecó, ela disse que Tio Salvador havia retirado alguns pertences do senhor indígena da cabana antes do incêndio, prevendo que algo assim poderia acontecer. Dentre os objetos salvos havia um caderno. Aparentemente, o senhor indígena vinha tentando escrever a sua história. E diante daquela revelação, fazia todo sentido que a minha presença fosse esperada por ele. Menos por vias ocultas e mais por necessidade. Pedi uma sugestão a Arlene sobre o que fazer com os pertences que Tio Salvador pretendia me entregar. Ela sugeriu que os levasse ao Centro de memória do Oeste de Santa Catarina, localizado no piso superior da rodoviária onde icavam os Kaigang. Era onde também a autora do livro da cidade, Domingas, havia feito uas pesquisas de arquivo. Além dos registros oficiais da historiografia regional, o CEOM antinha um acervo dos povos indígenas de toda a região Oeste.

Xontinuei em contato constante com Andreza. Tio Salvador costumava ir para Chapecó de 5 em 15 dias para fazer as sessões de quimioterapia. Ela fazia questão de me avisar a róxima data para que eu pudesse pegar os objetos diretamente com ele. Tentei retomar as eituras na biblioteca da universidade, mas logo recebi uma mensagem de Êlo com uma Jrande novidade. Há minutos atrás, ela me dizia estar contando o caso do senhor indígena para sua irmã Marluce. Estavam, as duas, na recepção da fábrica de roupas de sua família, quando uma cliente que aguardava por um ajuste das costureiras, meteu-se na conversa. Dona Neiva, como era chamada, acabara de confirmar a elas que o senhor indígena de fato morava no bairro da Gruta, muito próximo a casa de uma conhecida. Segundo a moradora, que conhecia a história apenas de ouvido, era sua comadre, Dona Di, quem mantinha contato direto com o Índio. Ela costumava ajudá-lo com comida e algumas roupas, como outros vizinhos do bairro da Gruta. De repente, a história de Andreza havia ganhado novos elementos. Como se, novamente, os meus objetos de pesquisa recusassem a terminologia escolhida por mim. A narrativa desfiada por Andreza surgia agora com outros fios sendo puxados por narradores como ela. Dona Neiva assegurou a Êlo e a irmã que, de fato, se tratava de um índio autêntico, nas suas palavras. Tinha a pele morena, olhos puxados, cabelos negros e lisos que cobriam as costas até a cintura. Nas poucas vezes que 
saía da cabana, andava vestido com uma pala de gaúcho enfeitada com detalhes étnicos nas mangas. Era verdade também, segundo ela, que nos últimos tempos ninguém mais o vira. Provavelmente estava deprimido com a morte da mulher e da filha. Por último, revelou que os vizinhos tinham medo dos rituais que ele fazia no escuro da cabana. O que justificava a atitude de Tio Salvador em salvar os pertences do senhor indígena, antes que alguém os eliminasse. 


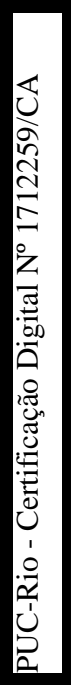

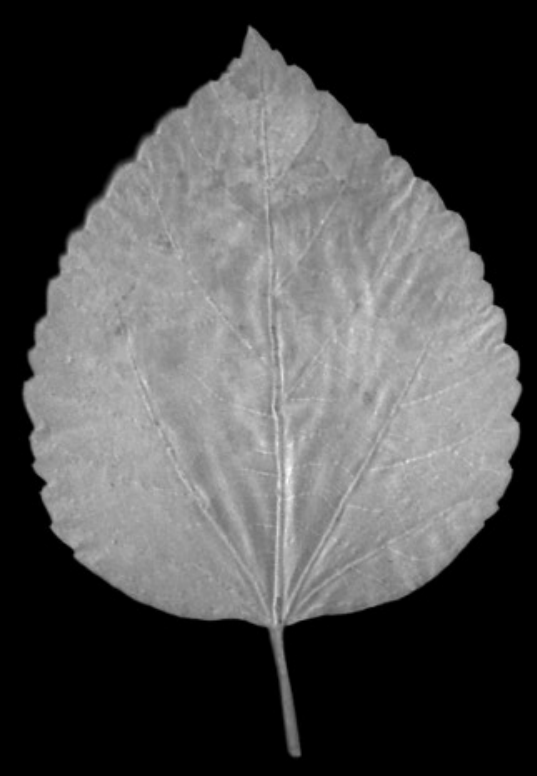

- I2 - 


\section{I2.29 O rabo da onça}

Demorou para que o escritor notasse a presença de Alma ao lado da igreja observando o grupo de bandeirantes que trabalhava na praça

O engenheiro já havia anotado as medidas do canteiro na sua prancheta e os ajudantes faziam marcações pelo chão no ponto central do terreno Sobre o pedestal reforçado seria erguida a estátua e ferro fundido

do governador Konder

S raios da manhã

que já tostavam as folhas das árvores

orturavam os olhos do escritor

ua língua rasteja em um deserto

e a cabeça martelava

a cada lembrança

das cervejas do Senhor Braun

Quando finalmente sentiu os olhos distantes

fixados na sua pessoa

reconheceu a aparição

trajada de negro

ao lado da torre de madeira 
Largou o grupo de lado

e foi apressado na direção de Alma

Antes mesmo de atravessar

a estradinha de cascalho

o escritor leu os olhos carregados

e as mãos trêmulas da colona

que seguravam a barriga

como se o bebê pudesse deixá-la

Alma confirmou
o que o outro previu
e logo em seguida desaguou

É Vitorino

Saiu no meio da noite

não apareceu em casa

té agora

Duando o chefe de polícia da caravana

vinha galopando pela picada

lma agarrada na traseira

o escritor no cavalo ao lado

evantando poeira

Vitorino parecia ter acabado

de chegar pela trilha do riacho

A mulher olhava com assombro

aquele corpo de gigante massacrado

Os trajes do baile

estavam cobertos de terra

os cabelos vermelhos espantados

e os olhos perdidos

na cara imunda 
Trazia arrastando no chão

a sela do cavalo

que largou aos pés de Alma

logo que ela arriou da garupa

nos braços da autoridade

A mulher tapou a boca

assim que o grito de espanto escapou

Os olhos debulharam água

quando o marido tirou a carabina

deitada do ombro

Enrolado no cano da espingarda

havia um grosso

e comprido pedaço

de algo

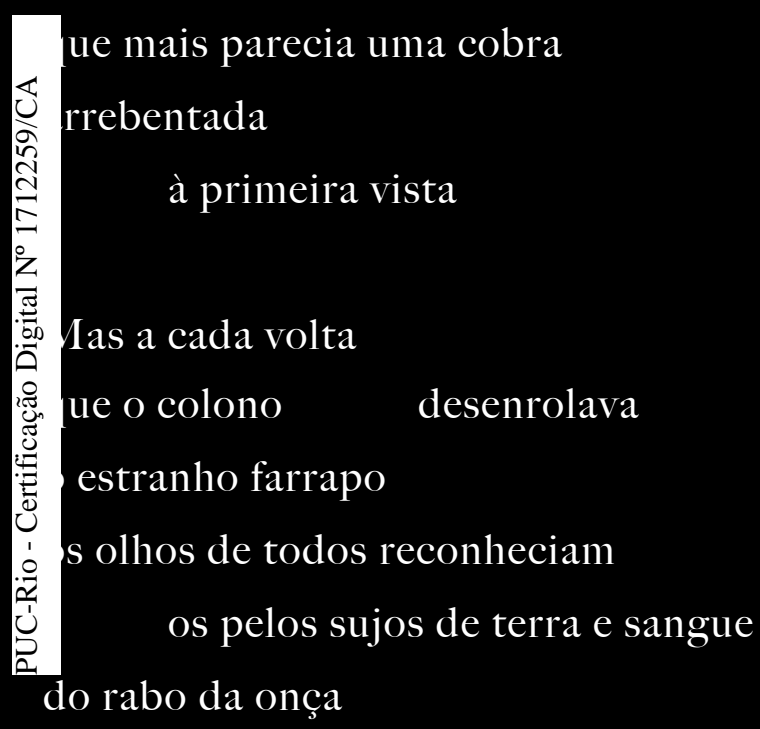

Mesmo sem nunca ter visto uma

E que o colono estendeu

para o Senhor Gama

olhando dentro dos seus olhos

de escritor 


\section{I2.92 O rabinho escondido}

O oratório da Santinha

que sempre chegava

pra passar a semana

pelas mãos de Dona Norma

estava em cima da chapa fria

do fogão de ferro

mas desta vez

não havia nenhum vaso

de margarida daqueles

que ela sempre trazia

quando Mãe Clara voltava

造lo hospital

'ai Vitório

inha da cabana

com o Gegê no ombro

travessando o parreiral

como um cão

a arejador

É onça

É onça

Aquela ave

gagá

repetia

de volta na gaiola

enquanto eu mastigava

as sementes do melão

com os olhos

escondidos 
O palito de dentes

passava de um canto

a outro dos lábios

de Pai Vitório

O silêncio de bicho traiçoeiro

foi quebrado pelo rádio

III Nenhum acordo foi alcançado na reunião promovida pelo prefeito entre os representantes do governo estadual a Funai e os índios A missão de paz enviada pelo governador aterrissou no Estádio Municipal Folhas Verdes no dia de ontem e retorna hoje para a capital A expectativa era convencer os indígenas a trocarem a área conquistada na justiça por outra menor fora da cidade $\mathrm{O}$ vereador indígena Roberto Carlos que está à frente do movimento informa que o grupo não vai abrir mão das terras e que a demarcação 

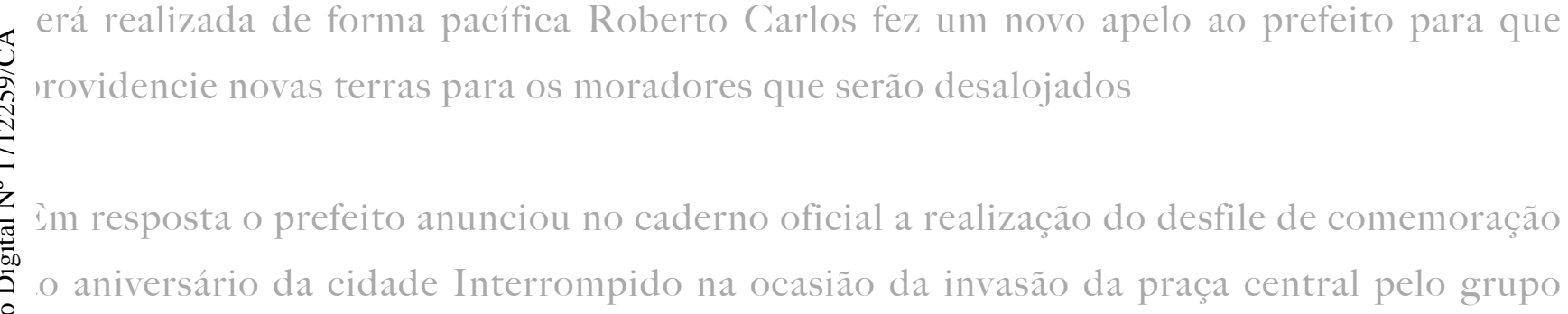


Quando eu já estava quase

na soleira da porta

do quarto de Mãe Clara

a voz encorpada

chamando meu nome

completo

obrigou

a dar meia

volta

Pai Vitório me puxou

pro joelho pontudo

dele

e começou a enrolar

, meu rabinho

ญै le Rei Roberto com o dedo

Igualzinho àquela noite

o restaurante de espeto

corrido

敢 nde paramos pra descansar

:

لَّ

ro Mato Grosso

da estrada longa

Depois

de preparar a minha cama

na boleia

Pai Vitório foi encontrar

os caminhoneiros

que armavam redes

na carroceria

e cozinhavam

no fogareiro 
Os faróis que corriam

na rodovia

entravam na cabine

junto com as risadas

espalhafatosas

Uns assobios

de pássaros desconhecidos

correram pelo pátio do posto

vazio

Falas macias

dissolveram a vozeirada

em conversas moles

sussurros

risos adoçados

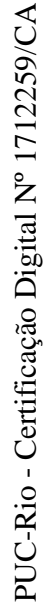

)etrás da roda

da carroceria

i as pernas compridas

altos

iontudos e saia curtinha

Ela saiu apoiada no ombro

lo motorista nanico de boina

equilibrando

nas pedras do calçamento

até o mato

nos fundos do pátio

De tão avantajada

a sombra dela engolia

o baixinho

inteiro 
$\mathrm{Na}$ roda de homens

a voz de Pai Vitório

reinava com a piada batida

do Rei Roberto

Além roubar o coração

da mulher

que ouvia os discos do galã

enquanto ele vivia nas curvas

da estrada

Um índio

com o nome do cantor

tirou sua vaga de vereador

iludindo os corações

dos eleitores

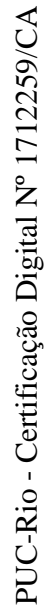

motorista nanico

voltou cuspindo juras

le morte à rapariga

impostora

ue mijava em pé

no tronco

da árvore

Os caminhoneiros

largaram o fogareiro

a carne chiando

e bandearam

pros fundos do pátio

como caçadores

embalados por cães

famintos 
Um urro de onça

fingido veio do escuro

disparando gargalhadas

orangotangos hienas e porcos

selvagens

aumentavam o coro

infernal que se alastrava

no mato riscado

pelos clarões

e buzinas

da rodovia

Um grito rouco

e desesperado

calou a baderna

por um

ป̛

segundo

$((((((()))))))$

depois afundou

nas sombras

da noite

Berros

Arrastos

Esperneios

ecoavam no posto deserto

com as luzes brancas

falhando 
Os urros dos caçadores

deram trégua

quando o dono do espeto

corrido

gritou do restaurante

ameaçando

chamar a polícia

\section{Durante o resto}

da noite

um choro raivoso

corria o pátio escuro

pelos cantos

O miado de onça

senetrava pelas frestas

da cabine

ลี

¿ 'ai Vitório

briu a porta antes do sol

om a cara lavada

:

is nisturada com cigarro

ํํㄹ

sistas

sujas de terra

e um pastel de carne moída

embrulhado

Foi a última parada

que fizemos até o final

da viagem 
Ele passou os dias

e as noite seguintes colado

no volante

dando goladas na latinha

de coca

que nunca secava

baforando pela janela

Eu nunca esqueci

daqueles arranhões

abrindo a carne viva nos braços

$$
\text { peludos }
$$

Nem dos dedos

inchados

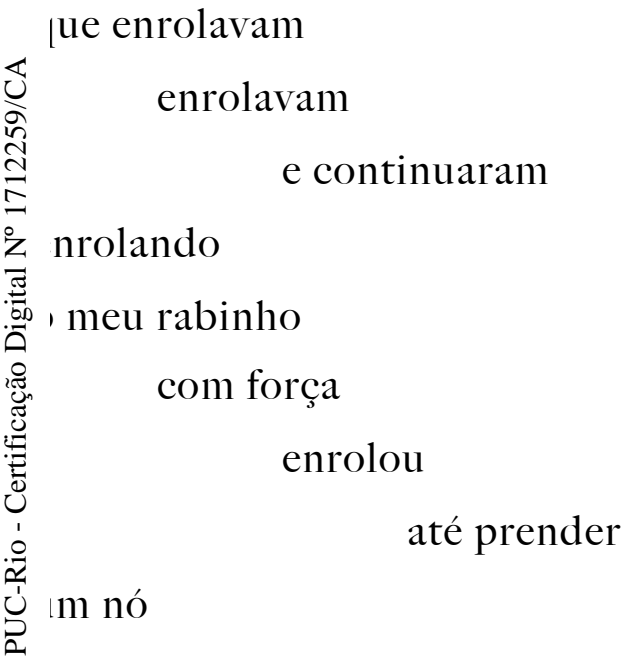

que puxou

pela raiz

arrastando

pelo terreiro até

a cabana

toda revirada

as enciclopédias

os soldadinhos

as sementes

esparramados

pelo chão de terra 
O tapetinho jogado

no canto

e o buraco aberto

com a saia curta

malhada de Morena

e o uniforme sequestrado pelo

Armeiro

no corpo de Espingarda

sujos da terra

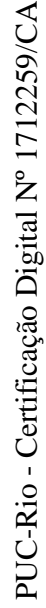




\section{Nota I2}

No meio da semana viajei até a cidade de Frederico Westphalen para uma visita ao CIMI. Frederico foi diretor da colonizadora que construíu a cidade de Iraí, logo ao lado. E diferente do Coronel Ernesto Bertaso, não emplacou o próprio nome apenas em um hotel, mas na sua cidade. Encontrei os dois missionários responsáveis pelas questões indígenas da organização. Mário e Ivan me receberam em uma salinha pequena, de paredes escuras e atulhada de caixas e arquivos. Conversamos sobre a situação atual dos Kaigang em Iraí, depois da longa trajetória de retomada das terras, concluída em I992. Foram io anos de disputas judiciais contra o município, orientadas pela organização religiosa até conseguirem o direito das terras de origem. Pude olhar as três pastas de arquivos que continham registros do episódio da retomada. Na sua maioria eram recortes de notícias os jornais regionais que se referiam ao grupo pelo nome da etnia, embora tivessem ariações como Caigangues e Caigangs, e os identificava como invasores. Outros nateriais, ainda, mostravam perspectivas contrárias àquelas veiculada pela imprensa. $\mathrm{O}$ audo antropológico das terras que comprovara o caráter imemorial da área, as atas de euniões com lideranças indígenas e políticas, cartas dos indígenas aos habitantes de Iraí e m material didático para a campanha de retomada das terras feito com a ajuda dos nissionários. Este último, um folheto, contava a história do grupo.

iferente de Caibi, foram eles, os Kaigang, que escolheram a nomenclatura que dá nome à cidade. Iraí, em tupi-guarani, significa "águas de mel”. Uma referência ao rio que cruza a cidade até desembocar no rio Uruguai, onde estavam as fonte de águas termais, frequentadas por eles desde 1898 . Com a chegada da colonizadora, foram removidos do local para a construção da cidade. Na mesma lógica dos anteriores aldeamentos em que Vitorino Condá negociava indígenas com os governadores de províncias e fazendeiros para a redução da população indígena, a “limpeza étnica” era feita através da articulação entre as empresas colonizadoras e o antigo Serviço de Proteção aos Índios e Localização de Trabalhadores Nacionais - SPILTN. Grupos indígenas eram confinados em áreas restritivas, as chamadas terras indígenas (TI's), liberando as terras para a criação de novos loteamentos e para a produção agrícola. Segundo a narrativa dos Kaigang, alguns de seus integrantes retornaram foragidos à região na década de 1920. Entre eles estava o Cacique Nonoai, que costumava fazer o uso medicinal da fonte de água termal antes de morrer no 
local. Desde então, os Kaigang acompanharam as reformas urbanas e sanitárias promovidas por Vargas. Empurrados cada vez mais para as margens da cidade, viveram muito tempo do outro lado do rio, em uma faixa de terra com apenas i hectare. Era dali que vinham as crianças indígenas de quem minha mãe comprava artesanatos nas nossas idas ao balneário.

Enquanto eu tomava nota e fotografava os materiais, Mário e Ivan foram convocados a estarem presentes na aldeia de Iraí por conta de um achado arqueológico. Ofereci-me para ir junto, mas a aproximação com os indígenas não era tão simples para um pesquisador da área de Letras.

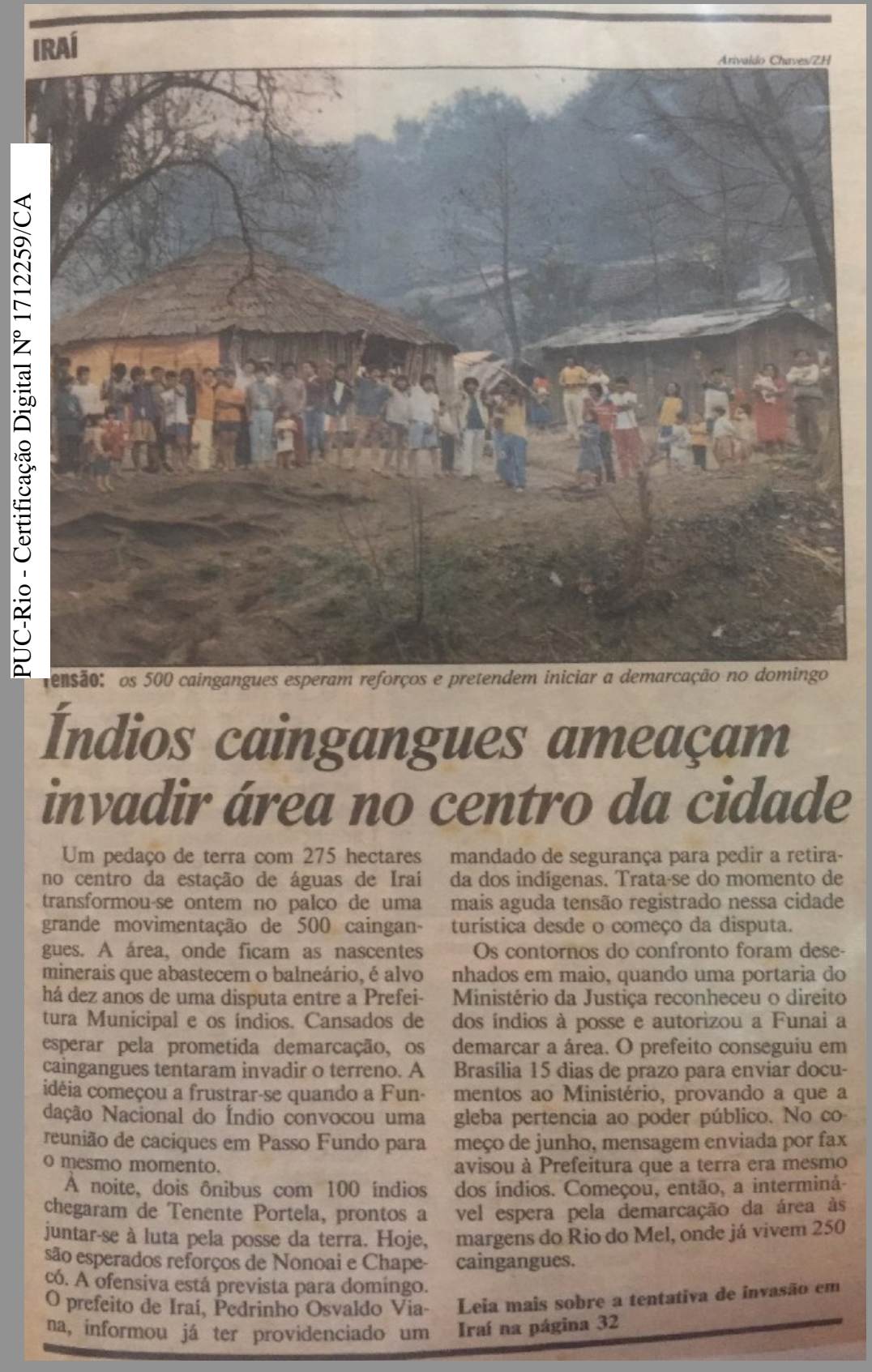

Figura II - Fotografia da manchete de jornal Índios caigangue ameaçam invadir área no centro da cidade 


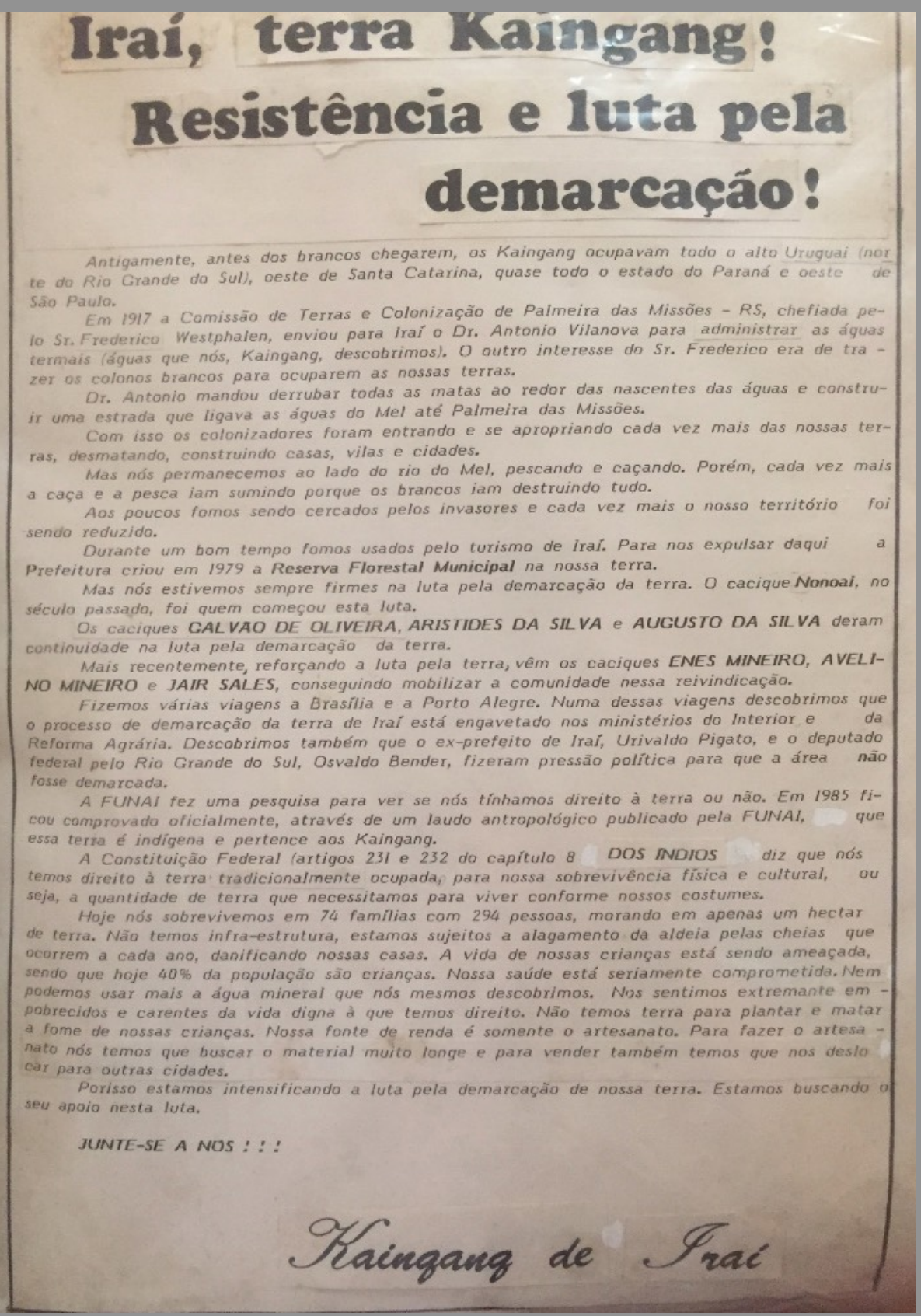

Figura I2 - Fotografia do folheto dos Kaigang à população de Iraí 

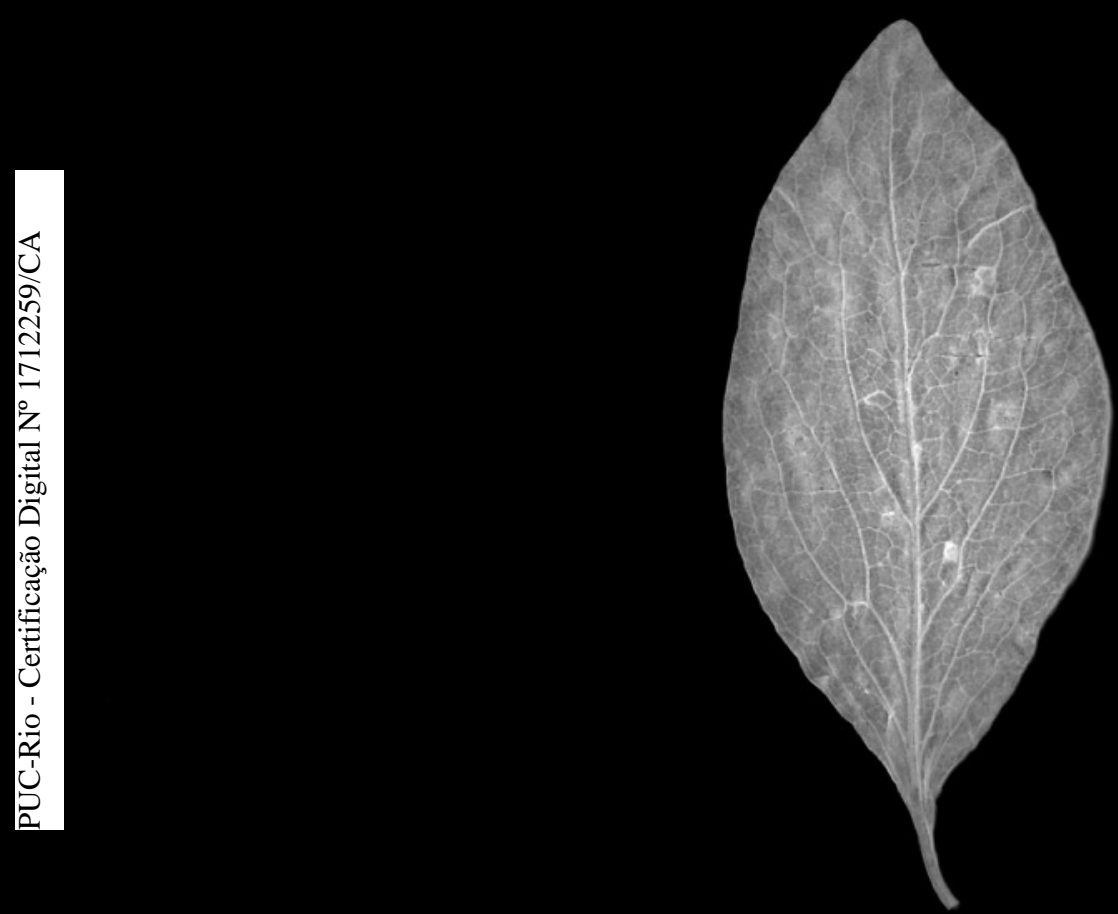

$-13-$ 


\section{I3.29 Ao jornal República}

Aos leitores que nos acompanham

nesta aventurosa viagem pelo sertão esquecido

peço desculpas em nome da caravana

do governador Adolpho Konder pelo sumiço

Na última missiva publicada neste periódico todos devem lembrar

estávamos ansiosos para adentrar nas florestas

Abandonamos as lanchas

batizadas de Konder O Primeiro

Segundo e Terceiro

para entrar na floresta bruta

onde não há trilhas nem caminhos dados

alvo as marcas que ainda restam das picadas abertas

elos índios que aqui viviam

o passado

Jm desses gentios

restou serviço memorável à pátria

Vitorino Condá arrebanhou centenas de índios bravos

ara fazerem parte da nação

Nas noites em que nossos guias acendiam fogueiras

tive a chance de ouvir as lendas

sobre o herói selvagem

Areias um caboclo de alma verde

dessas terras

e exímio contador de causos

não poupou nossos corações 
Revelou diante do fogo

enquanto a fumaça desenhava um imenso cocar

na escuridão

que os miados de onça

e a catinga característica do feroz animal

que rondavam a caravana desde o primeiro dia

eram sinais de Vitorino Condá

\section{Demos graças}

ao deixar o inferno verde

depois de 6 dias nele internados

Chegamos na pequena colônia

dirigida pelo Senhor Leintz nas margens do rio Uruguai

Esses homens de bem e boa

vontade que trabalham como abelhas

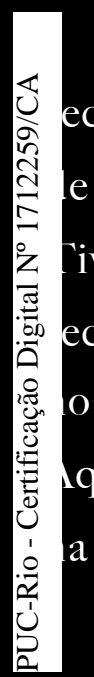

criando o seu favo de ouro

eceberam a todos os bandeirantes

e braços abertos

ive a sorte de ser acolhido por um casal de colonos

ecém chegados da colônia velha de italianos

o estado vizinho

quecido com grossos cobertores de lã

a simpática residência

qual não foi o meu desespero caros leitores

quando fui acordado no meio da noite

enquanto escrevia estas linhas

pelos mesmos miados

e idêntica catinga

que rondaram

o nosso

acampamento 
Eis que minha sorte

ou destino alguns de vocês diriam

foi haver ganhado abrigo na casa

do mais bravo dos colono

Senhor Vitorino Natal

Depois de dias acompanhando os rastros do perigoso bicho

que frequentava as terras da colônia

como se fossem de sua propriedade

Vitorino descobriu que o invasor

fez sua morada preferida

perto da fonte de águas milagrosas da colônia

ao lado de uma cabana desocupada

O sertão está infestado de manchas

omo esta

choupana que abriga intrusos

ara melhor

xplorar as matarias

Reconhecido o inimigo

o colono que leva no nome a coragem

ez uma emboscada digna de ser registrada

as páginas da história

No meio da noite levou seu cavalo até a cabana

e ficou em prontidão como um soldado treinado

No momento

em que o bárbaro animal

se atracou nas carnes da isca

Vitorino disparou um tiro certeiro

pelas costas da onça

À participação desse bravíssimo brasileiro

na construção de uma nação verde e civilizada

prestaremos nossa homenagem

na cerimônia de despedida da colônia 
$\mathrm{Na}$ ocasião teremos outra ilustre presença

que guardo o nome em segredo de estado

para que vocês leitores

não percam nenhum capítulo

da obra de brasilidade mais empolgante

desses últimos anos de

República 
I3.92 Uma emboscada para os bandeirantes

Os ex-bandeirantes chegaram juntos

no chafariz do parque florestal

onde tínhamos combinado

Maico parou na entrada

os braços cruzados

os bigodes de groselha

enquanto Satriano apalpava

as calças como se tivesse

um saquinho de bolinhas

de gude

por baixo

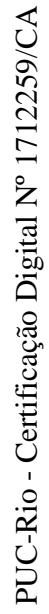

Patrício era o único

onvencido cem por cento

le que aquela criatura

solta pela cidade

meaçava

honra dos bandeirantes

)s outros dois paus

mandados

só aceitaram

participar da emboscada

depois que eu

JUREI

na frente deles

que Camarada Espingarda

não fazia mais parte

do grupo

E registrei

oficialmente

no caderno de couro 
Carregamos nossas maletas

com pedras

na beira do riacho

e seguimos pela trilha

que eu inventava

de acordo

com as folhas

No alto

a revoada de rolinhas

tico-ticos e os quero-queros

escurecia o céu limpo

e castigava os ouvidos

com a a gritaria

loida

ญু

'atrício era filho

lo maior dono de frota

喿 de caminhões da cidade

e carregava a faixa

lo Dom Pedro nos desfiles

mas ficava assustadiço

om qualquer grilo

saltando

detrás das folhas

Levei os três

até a moita alta

com vista pra cabana da onça

pintada

e pedi que carregassem as malhas

dos bodoque

com os pedregulhos 
E apontassem

as armas

pelas minhas costas

dando cobertura

enquanto eu avançava

no território

inimigo

Chequei a janela

com sinal de positivo

e escorei nas taquaras

ao lado da abertura

da porta

Da moita

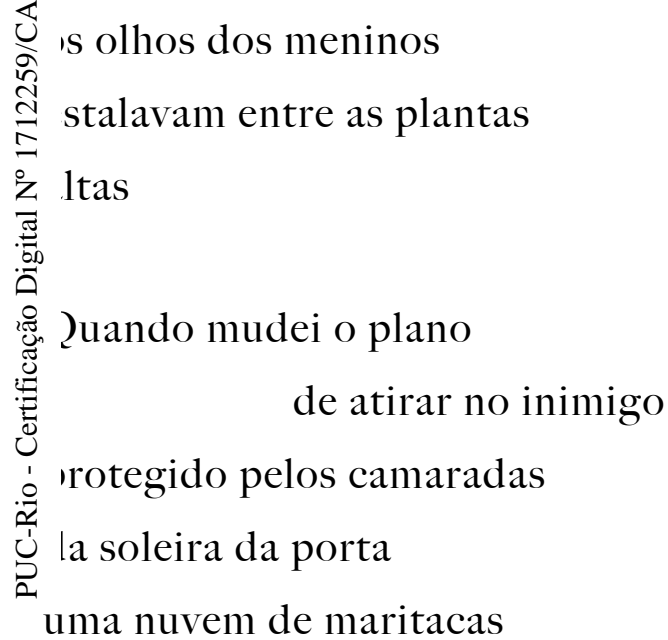

desprendeu dos galhos

da árvore ao lado

e os gritos roucos

ecoaram pela mata

inteira 
Os bandeirantes agitavam os braços

detrás do esconderijo

Patrício já tinha juntado

as mãos implorando

para terminar

a missão

Pedi silêncio

com o dedo nos lábios

o peito estufado

esticando o elástico do bodoque

e dei o primeiro passo

Camarada Espingarda

eria se impressionado

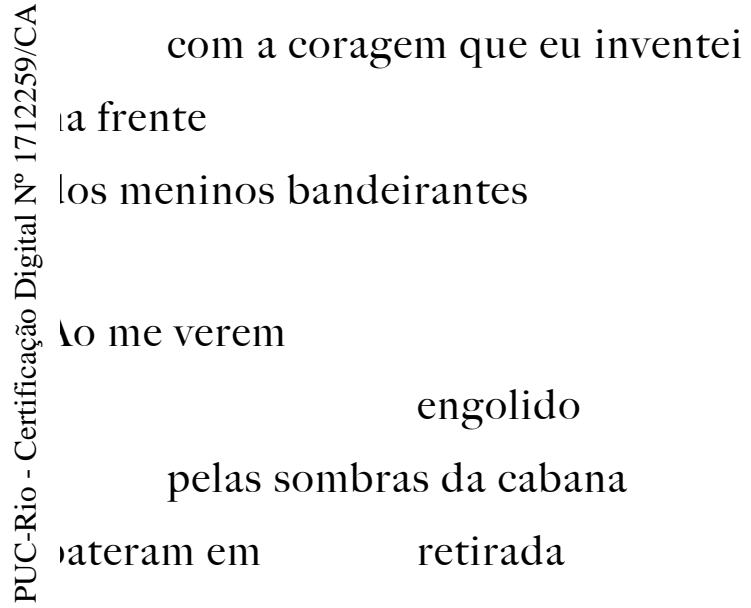

Fiquei lá dentro

até os passos

disparados pelo mato

desaparecerem

Nem imaginaram

eles

que uma onça jamais

daria as costas

pra um bandeirante

atirar 


\section{Nota I3}

Comecei a contactar algumas pessoas de Caibi por telefone, antes da etapa final, em que ouviria os caboclos sobre os primeiros tempos da cidade. Além da mãe de Eloísa, um vereador da cidade - ele próprio um caboclo - e o dono da rádio local me ajudariam a chegar aos entrevistados. Telefonei também para Domingas, a autora do livro de memórias da cidade, que fez algumas sugestões. Àquelas alturas, toda a cidade já estava sabendo que eu andava por lá. Antes de chegar em Caibi, Andreza me avisou que Tio Salvador iria ter que viajar para Florianópolis fazer uma cirurgia de emergência. A notícia me fez reviver as inúmeras cirurgias que minha mãe fez por conta do mesmo câncer maligno. Alguns dias antes da morte dela tive um sonho que logo tomei nota ao acordar. A imagem que restara, hastante fantasiosa, era a de um menino preso dentro de um poço vazio, enquanto uma nça estava do lado de fora, na superfície. Como é comum nos sonhos, o cenário era o uintal da minha casa de infância. No dia do velório dela, uma fila enorme se formou na orta da igreja. Pouco antes de carregar o alaúde em procissão até o cemitério, recebi a nensagem de uma amiga que me presenteava com uma ilustração feita a partir daquele onho. Diferente de como eu havia descrito, na versão de minha amiga Priscilla o menino e onça apareciam lado a lado. E parte do corpo de criança estava sobreposto ao de bicho. tomo em um estado de incorporação, como o transe místico que experimentei com a ntidade espiritual. Mas também como um caboclo encantado, que se transforma em seres a natureza viabilizando-se a partir de uma radical experiência de alteridade. Os encantados como homem boto e a cobra grande vivem neles mesmos, diz o filósofo das macumbas. Vivem no elemento da natureza em que se encantaram e vivem no outro corpo em que, pelo transe, se manifestam.

A primeira vez que vi uma onça foi durante uma visita ao circo que havia armado a lona em um campo de futebol da cidade. Meu avô me pegou no colo para que eu ficasse da altura dela. A proximidade com aquele bicho tão fascinante e tão assustador me fez vomitar imediatamente. Esta lembrança já havia me ocorrido ao ler os trechos do diário de Gama D’Eça em que o escritor se sente amedrontado e intrigado pela onça que ronda o acampamento dos bandeirantes. Suas especulações mostram as diferentes visões que os homens brancos e os caboclos têm do animal. Enquanto o escritor e seus companheiros a veem como caça, os caboclos a tem como caçadora e dona das terras do sertão. Assim, esse 
mecanismo em que minhas memórias eram constantemente ativadas pelas semelhanças com o tempo presente, apresentou-se como um modo de escrita em constante cruzamento com os personagens da história de fundação da cidade. Esta percepção também veio seguida de uma lembrança. Uma das brincadeiras que costumava fazer com meu pai, quando menino, era um jogo com palavras em que me apropriava de expressões que já existiam. Certa vez, transformei o dito "novo em folha" em uma espécie de título, ou autodenominação: "Luiz em folha”. O que, na minha cabeça, não se tratava de outra coisa senão folha de árvore. Como se a minha propriedade fosse ser novo como uma daquelas folhas verdes da cidade. E que surgem, no tempo do agora, como as folha de papel em que eu já começara a escrever esta história. Prefigurando o presente no tempo passado, da folha nova de menino para a coleção de folhas que vinha guardando - em meio às folhas brancas do caderno - ao longo da viagem.

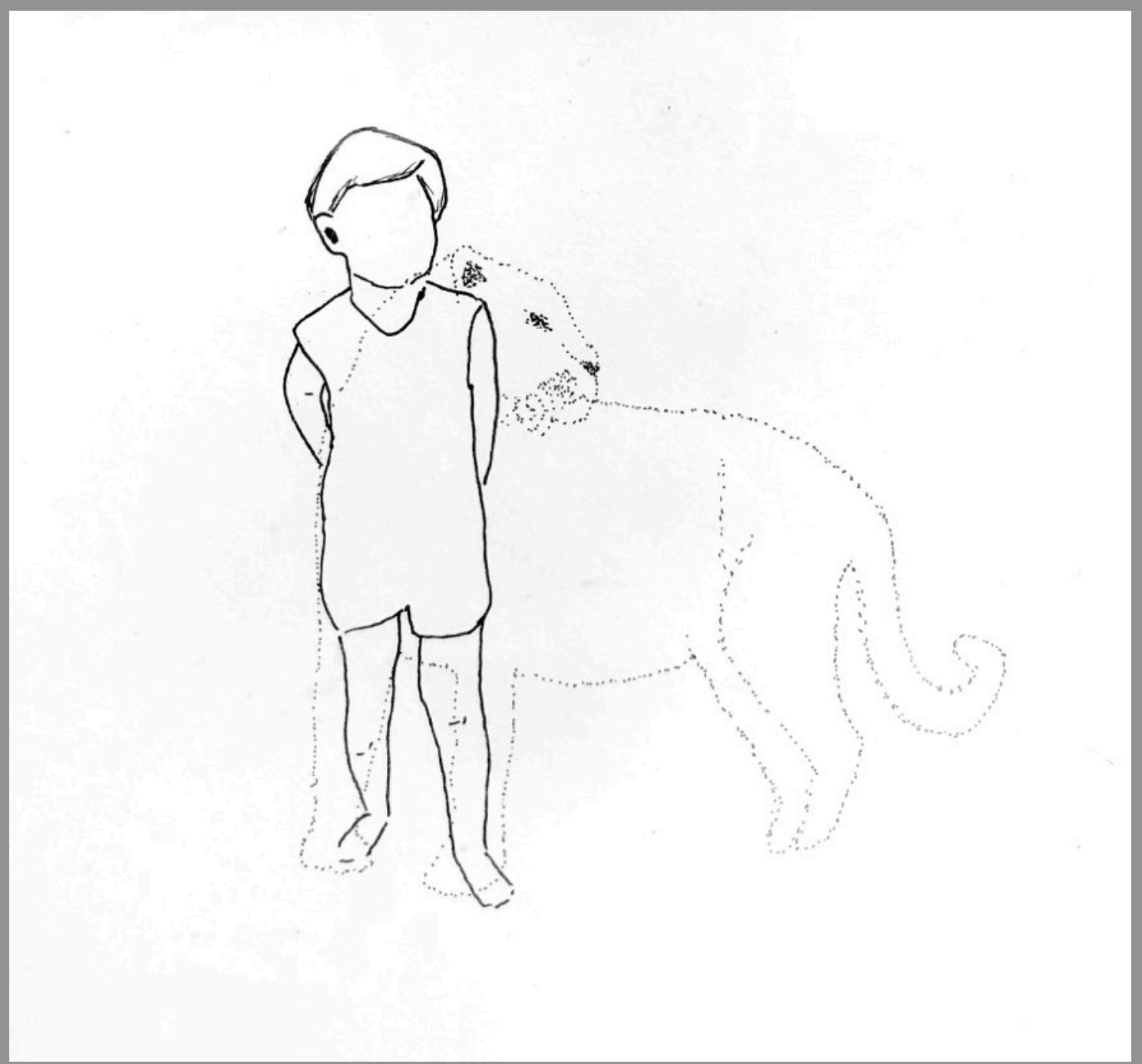

Figura I3 - Fotografia da ilustração do menino-onça de Priscilla Menezes 

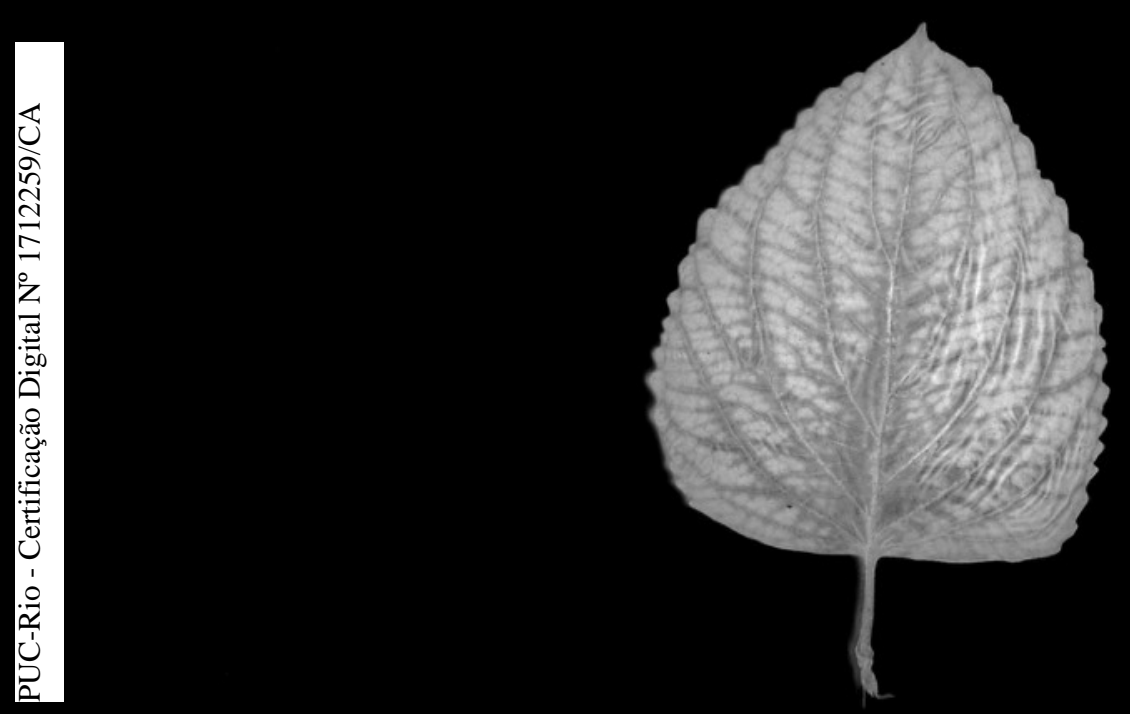

- I4 - 


\section{I4.29 O mapa da colônia}

Senhor Leintz abriu as portas da sua casa

na encosta verde do morro

e levou o grupo de bandeirantes

até o escritório

O escritor andava mais atrás

sentindo o cheiro de verniz e fumo de charuto

espiando as pinturas a óleo

aquarelas e águas-fortes emolduradas

uma vitrola

revistas ilustradas e livros

Não poderia estar mais em paz

com os ouvidos poupados

as teses históricas de Boiteux

do seu gravador de penas verdes

om cara de papagaio

Do gabinete do alemão

a janela abria uma vista para a colônia inteira

logo adiante se via o rio Uruguai

onde as balsas dos caboclos surfavam

nas corredeiras

Com as pranchetas na mão

trenas e lápis atrás da orelha

o agrimensor e o engenheiro

tinham o nariz colado no mapa

pendurado na parede verde-oliva 
O diretor tirava uma pilha

de pastas do armário

e colocava sobre a mesa

No alto do móvel lustroso

o escritor viu os vasos redondos

de cerâmica enfileirados

$\mathrm{E}$ isso?

Os gomos da testa do alemão

espremeram contra a boina

Ah isso

Os kolonos encontram muito

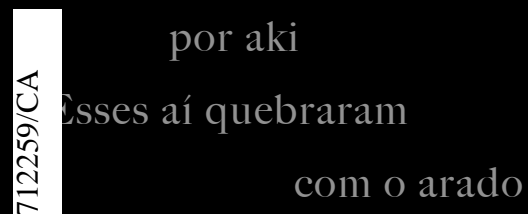

brindo a terra

escritor abandonou o batente da janela acompanhou o diretor até o mapa enquanto os dois matemáticos

omavam suas notas

Com uma régua

Senhor Leintz mostrou os lotes de terra inúmeros retângulos vazios

que ainda precisam ser vendidos para famílias de colonos

do outro lado do rio

Quem sabe agora

com toda essa propaganda

do koverno

a nossa kolônia 
Depois de alisar o cavanhaque

algumas vezes

o diretor colocou a ponta da régua

sobre um o único retângulo preenchido

na parte mais afastada da sede

e fez um zigue-zague no espaço

em branco do papel

Essa faixa de terra

também é da kompanhia

Mas a xente precisa

vender todos os lotes

antes de avançar

lle pegou o lápis do engenheiro
e foi traçando uma linha

o limite do mapa

nde os marcos da fronteira

recisavam ser

colocados

nesse ponto

onde fika a nossa fonte

de água especial

tem um espaço reservado

para o futuro balneário

O escritor que olhava

por cima das cabeças

dos bandeirantes

encarregados do serviço

brincou 
Tomara que as onças

não venham beber água

da piscina dos banhistas

O diretor respondeu sério

com uma ponta de zombaria

nos lábios

Onça

até que não inkomoda tanto

O que vai dar mais trabalho

são esses índios

das terra vizinhas

$\mathrm{O}$ antigo agrimensor

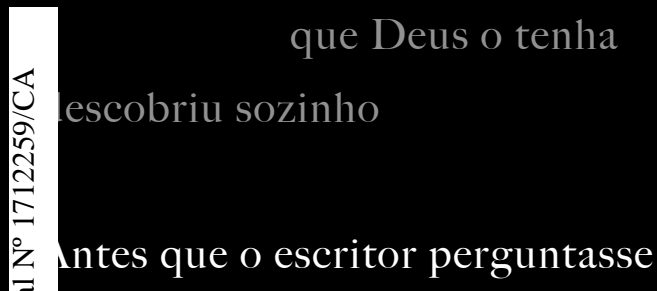

Senhor Leintz levou os dedos

ara fora do mapa da colônia

e desenhou um círculo qualquer

o meio da parede verde-oliva

Mas agora

eles ficam aqui

fora das terras

da kompanhia 


\section{I4.92 O último sonho de Vitorino}

Os foguetes e os tiros do Armeiro

arderam até à noite

depois que o prefeito convocou

os moradores

para o desfile

Vó Alma esperou o avô voltar

da ronda no terreiro

conferindo os arames instalados

e serviu pra ele

uma caneca cheia

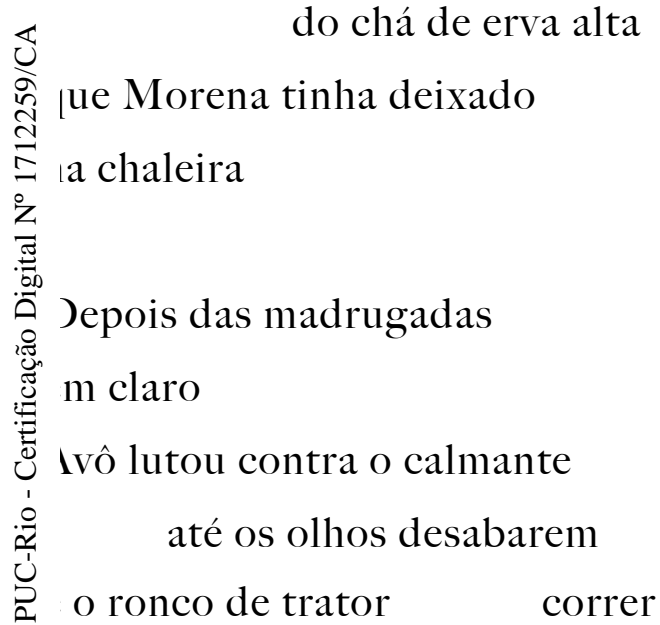

pela casa

O corpo grande e pesado

afundou como uma pedra

no fundo do rio

até que os pés

de fora do colchão

pisassem no mesmo chão

de tábuas

da casa cercada de mato

nos tempos

da colônia 
Avô Ino levantou da cama

de botinas calçadas

e o botão da camisa

apertando o pescoço

Acendeu o lampião

e deitou a carabina no ombro

pronto pra acompanhar o riacho

que passava em frente ao lote

de terra

distante da sede

A lua tinha subido bem alto no céu

redonda

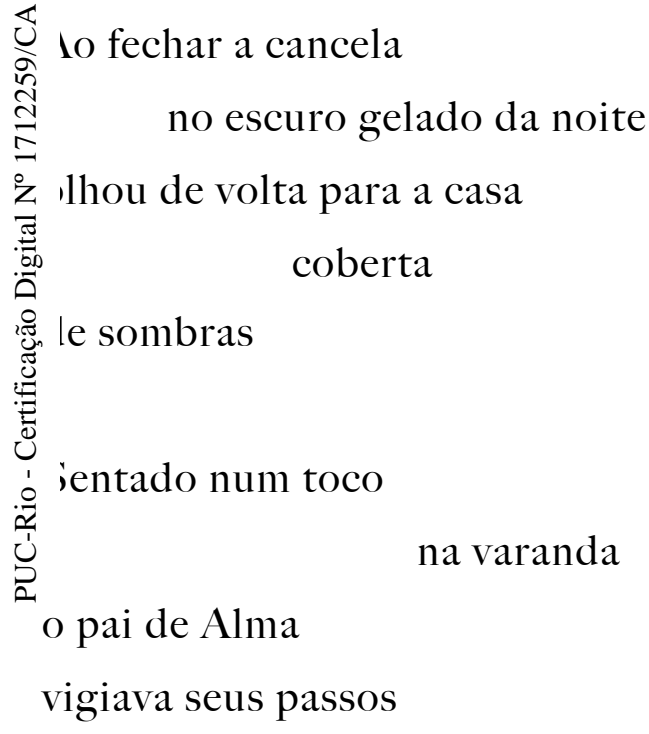

Com o peito carimbado

pelas patas do cavalo

balançava a cabeça

desapontado

O caminho até o olho

d'água da enseada não era tão longo

quanto este

em que andava

sem chegar 
As botinas antigas

apertavam os pés inchados

pelos anos

As pernas

enguiçavam a cada

metro

lavado de suor

O pássaro guardião

não avisou aos bichos noturnos

que o outro

Bicho grande

de pele clara

e rosto sarapintado

estava entrando na floresta

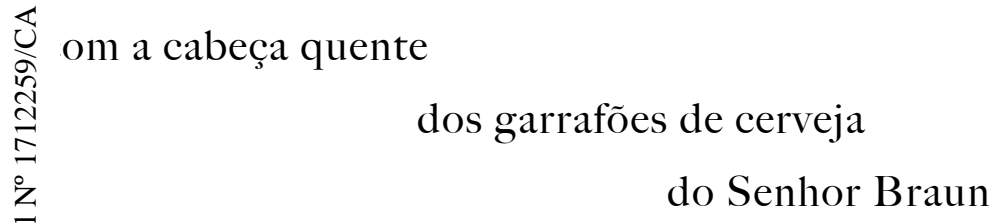

)a margem da enseada

descobriu uma chama

remulando

le dentro da cabana

com porta e janela abertas

Encontrou a mesma moita

de plantas altas

e ficou observando

as sombras

que dançavam nas paredes

de taquaras 
Uma voz cantarolava

um canto familiar

sem palavras

conhecidas

misturado com os estalos da fogueira

Vitorino levantou

do esconderijo num salto

com o comichão

no braço

Do meio moita

uma serpente

se afastava

escorregadia

o mato escuro

ป

ritorino tonteou a vista

as pernas bambearam

) sangue

fervendo com álcool

e veneno

la coragem

Seus olhos

cravaram na porta da cabana

onde a criatura selvagem

esparramava o corpo

como se fosse dona

daquelas terras

De costas era igual um índio

coberto com pele malhada

atracada num pedaço de carne

moqueada na brasa 
Dentro da sua cabeça

o pensamento serpenteava

com as ordens duras do diretor

os longos silêncios de Alma

e as risadas

que o escritor conquistou

com palavras cuidadas

e passos de dançarino

O colono apontou

o cano da espingarda

$$
\text { tremendo }
$$

A respiração maior

que o peito

a mão perdida na medida

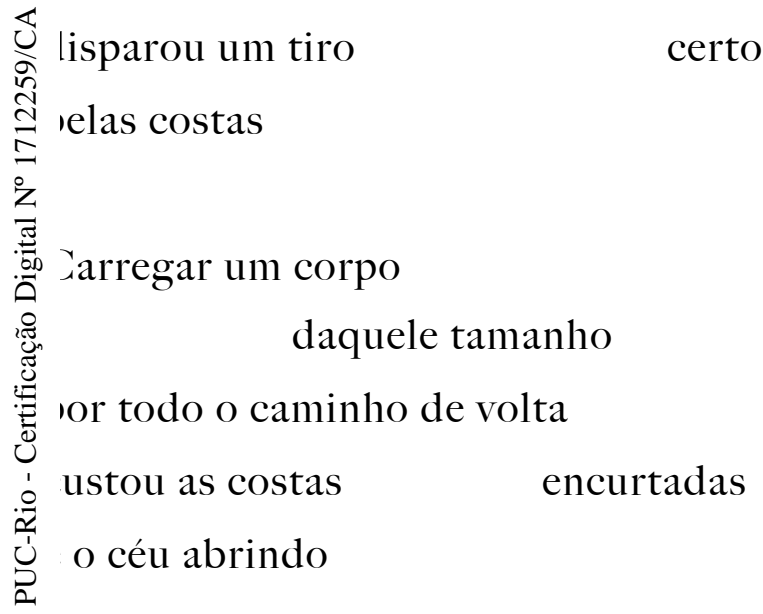

Vitorino cavou um buraco

largo

nos fundos do terreiro

e cobriu de terra e sangue

o seu segredo 
Na manhã seguinte

debaixo do céu aberto

foi Casimiro quem primeiro

chegou no terreiro

pitando fumo

com um cacho de bananas

do seu rancho de presente

Estranhou o poço seco

com o tampo aberto

Olhou no fundo

da garganta de pedra

toda cavoucada

e avistou Avô Ino

lentro do fosso

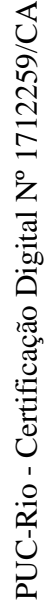

coberto de terra

sem batimento 


\section{Nota I4}

Comecei a fazer as entrevistas com os caboclos. Depois da primeira visita, em que fui apresentado pela mãe de Êlo à Dona Pedra, os moradores do bairro da Gruta apareceram em um fluxo vivo. De Dona Pedra para Margaria, de Margarida para Dona Nélcia, de Dona Nélcia para Seu Zózimo, de Seu Zózimo para Seu Ercílio, de Seu Ercílio para a Mulher-do-finado-Bem-te-vi, da Mulher-do-finado-Bem-te-vi para Dona Generosa, de Dona Generosa para Seu Nêne Bergamota, de Seu Nêne Bergamota para Seu Orides, de Seu Orides para Seu Amantino, de Seu Amantino para Seu Alivério, de Seu Alivério para Seu Adão, de Seu Adão para o Irmão-de-Seu-Adão, do Irmão-de-Seu-Adão para Seu Ari, de Seu Ari para Dona Maria, de Dona Maria para Seu Noé, de Seu Noé para Seu Dinarte. Transitei de uma casa a outra tomando chimarrão e ouvindo os causos dos primeiros empos da cidade. Nas nossas conversas, todas registradas em áudio e depois transcritas, omeçava sempre perguntando pela cabana do senhor indígena. E se testemunharam a resença de onças e indígenas naquelas terras. Dentro das suas cozinhas, ao lado do fogão lenha, meu sotaque nasalado se pronunciava. Grande parte deles vinha do município de almeira das Missões - ou Parmêra, como diziam - às margens do rio Uruguai, antes de rranjarem seus ranchos agregados às terras de colonos como meus avós. Viviam xatamente nas terras devolutas avistadas pela caravana de 1929, durante a sua passagem elo sertão, registradas como "manchas humanas" nos documentos históricos. Agora, as alas de caboclos que eu acabava de transformar em documento, além dos testemunhos que comprovam a sua presença no início dos tempos da cidade, também estavam registrados os causos das sereias que afogavam os balseiros no rio Uruguai, das bruxas que sobrevoavam os parreirais em busca dos vinhos dos colonos, além de um perfeito mito de fundação, em que Caibi é o nome de um velho colono que havia caído de um penhasco e foi ajudado pelos caboclos.

De volta aos arquivos do caso Kaigang, pude organizar os pedaços da trajetória que levou o grupo indígena a cravar sua própria bandeira no meio da cidade de Iraí. Depois de 10 anos de disputa, a decisão do Ministério da Justiça concedeu o direito de demarcação e ocupação das terras originárias. A ocupação do aeroporto da cidade foi feita depois de inúmeras tentativas frustradas de negociação entre o prefeito e a FUNAI. Diante da resistência da prefeitura e dos órgãos competentes em cumprir a resolução federal, os 
Kaigang tomaram a dianteira no processo de oficializar os limites do território recuperado. Ao fincarem os marcos para delimitar as terras, utilizando um gesto comum aos conquistadores mais antigos da história universal, é como se os Kaigang tivessem realizado o golpe astucioso dos caboclos encantados. A um só tempo relativizam as hierarquias impostas pelo legado colonial e desmontavam a ideia de origem impingida contra o seu povo. Já que fincar novos marcos corresponde a renunciar àqueles delimitados pela caravana de 1929. Os quais definem, no limite, o início da historiografia regional.

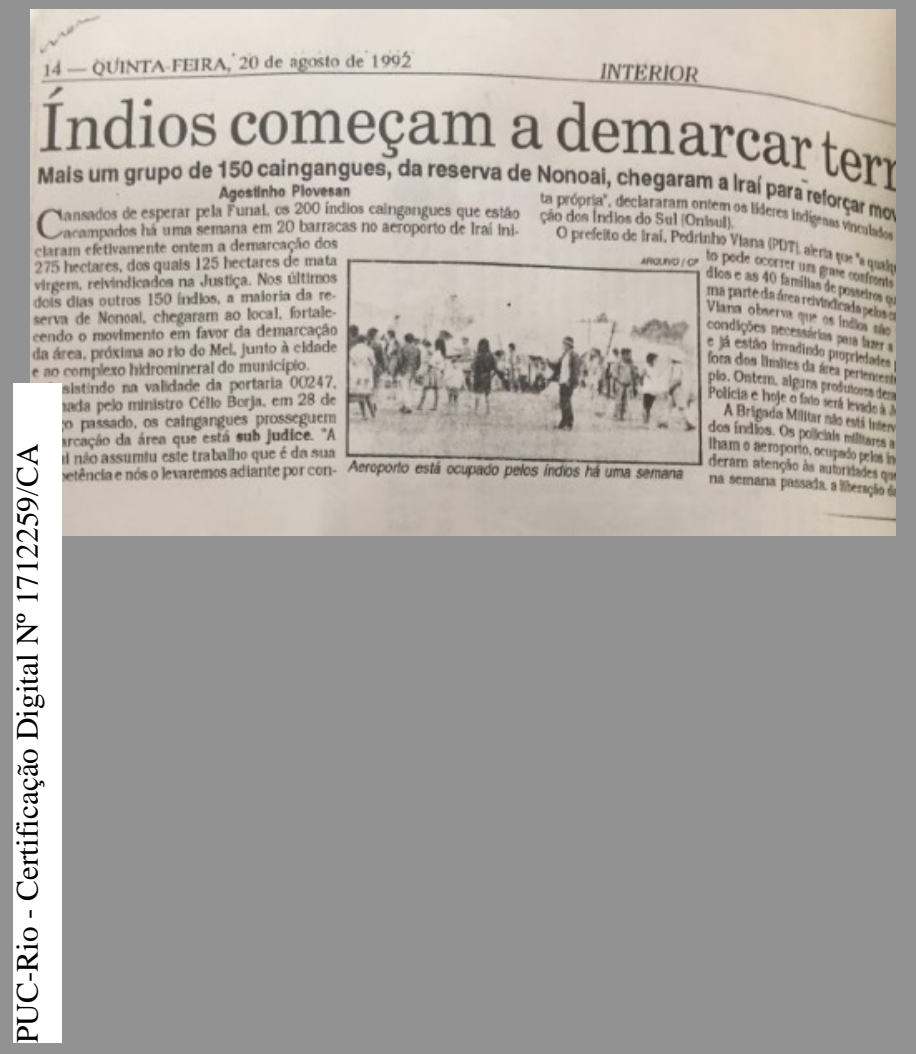

Figura I5 - Fotografia de manchete de jornal Índios fincam o primeiro marco
Figura I4 - Fotografia de manchete de jornal Índios começam a demarcar terras

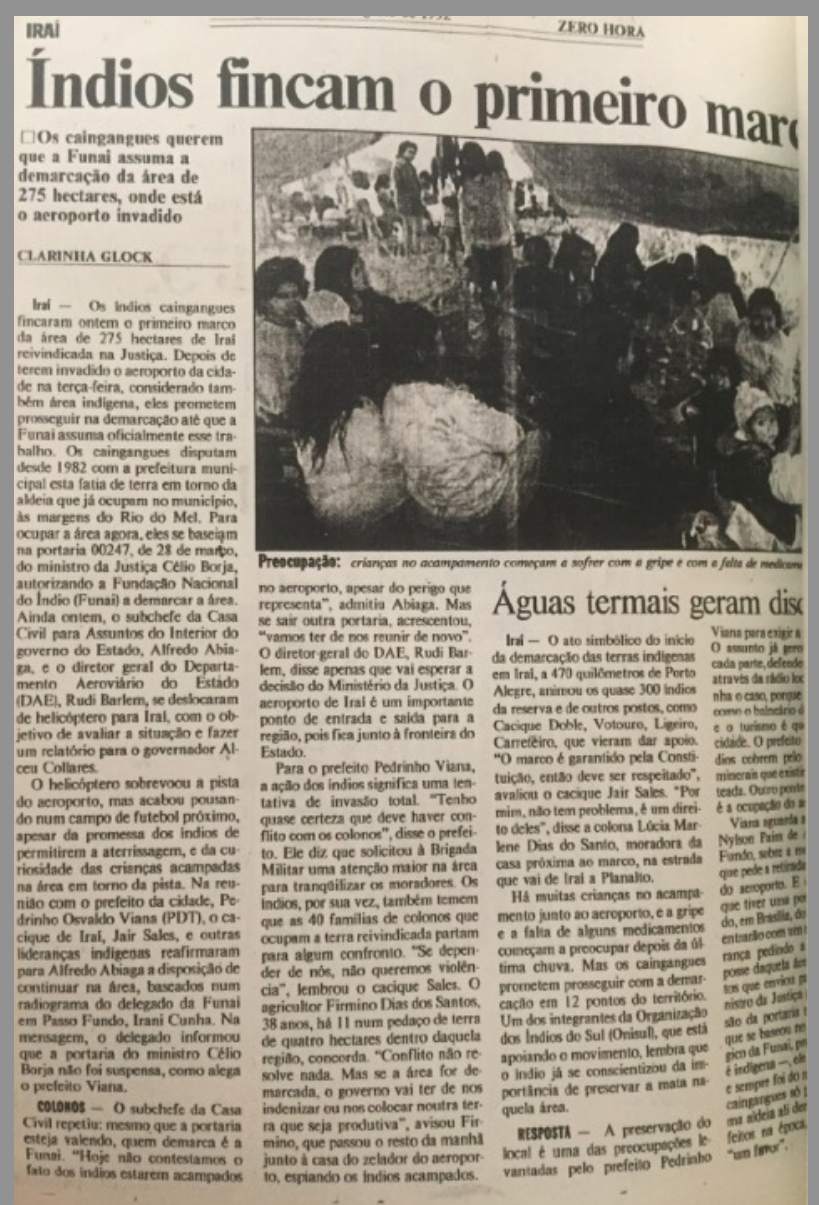




\section{Area Indígena de Iraí, 12 de agosto de 1992}

Caros Senhores:

A Comunidade Indígena Kaingang, localizada às margens do rio Mel, através desta, vem esclarecer a Vossas Senhorias que a Area Indígena de Iraí ficou caracterizada como de ocupação tradicional e permanente indígena, nos termos do artigo 231 da Constituição Federal e do artigo 17 da Lei $6001 / 73$ e conforme a determinação da Portaria nr. 00247 de 21 de maio de 1992, assinada pelo Ministro da Justiça Célio Borja e publicada no Diário oficial da União em 29 de maio de 1992.

2. Outrossim informa-lhe que a medida cautelar da Prefeitura Municipal de Iraí não tem validade, pois é posterior à assinatura da referida portaria. Se o Juiz Federal for manter o "Status quo" deverá ser em favor dos índios pois não existe outro ato que revogué a medida tomada pelo sr. Ministro da Justíça.

3. Considera o item III da resolução da Portaria nr. 00247 do Ministério da Justiça, a comunidade local apoiada por diversas áreas do Rio Grande do Sul e de Santa Catarina, resolve fazer a autodemarcação a partir deste dia, e reitera aos Senhores que a Comunidáde Indígena pacificamente realizará este ato e ainda colocase a sua disposição para apoiar, quando vossas Senhorias proc rarem - Órgão competente para fazer a desocupação da referida área.

Atenciosamente

Comunidade Indígena de Iraí

\section{Figura I6 - Fotografia do comunicado dos Kaigang ao município}





\section{I5.29 Folhas verdes}

A rajada de tiros chegou aos ouvidos de toda a colônia avisando que o barco do governador vizinho

finalmente havia atracado na barranca do rio Uruguai

As famílias de colonos se posicionaram

novamente na praça

com as roupas passadas de domingo

Diante delas

a caravana dos bandeirantes

tinha os semblantes restaurados

e reluzia como estatuetas polidas

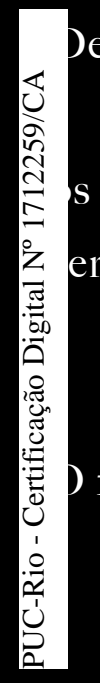

e costas para o pedestal vazio

sobre um pequeno tablado

dois governadores aguardavam o microfone

er oferecido pelo diretor sérios e firmes

como futuras esculturas

funcionário da companhia

correu o badalo do sino da igreja outra vez

\section{$((((((()))))))$}

O foguetório queimou no céu limpo

e os colonos entoaram o hino nacional

em posição de sentido

conduzidos pela pequena orquestra local

Durante o coro vigoroso e disciplinado

desta vez

o fotógrafo da comitiva explodiu o flash

capturando as famílias colonas de boca aberta

e as bandeiras que balançavam ao vento gelado

congeladas eternamente 
Ao final do último verso

com pátria amada e um Brasil esticando

os agudos prestes a rebentar

os heróis do sertão foram inundados

com uma saraivada de palmas

Vitorino olhava de longe para o escritor

com o queixo projetado para o horizonte

e a mulher abraçada no seu traje limpo

Depois do capelão agradecer pelo telhado da igreja

com uma missa

os chapéus as carabinas e os cavalos benzidos

O diretor estendeu o microfone

ara o governador do estado vizinho

pesar da metade da estatura do governador-bandeirante

e da voz de taquara rachada

quele homem atarracado e cabeçudo

hamado Getúlio Vargas

crescia aos olhos de todos

inflava o peito dos colonos desiludidos

om as palavras bem ditas que saíam de sua boca

Antes que o governador Konder

pudesse tirar o seu discurso do bolso

o conselheiro Boiteux

apontou com discrição

para o grupo de índios coroados

se aproximando da praça 
Senhor Leintz avisou o funcionário ao lado

que alertou os demais como rastilho de pólvora

Vitorino reconhecia pelo ar a catinga

de bicho

e espreitava de longe o olhar frenético do escritor

em direção aos nativos sujos de terra

roupas esfarrapadas e

cortes de cabelo franciscano

Ao avanço dos funcionários da companhia

armados com espingardas e pistolas

as famílias de colonos pegando os filhos no colo

Vargas deixou o segurança de lado

e foi até o grupo rendido

Puxou Senhor Leintz em um canto

esticulando palavras furiosas

até retornar endireitando o terno

Todos olhavam para aquele impávido pinguim

caminhando com passos de colosso

té os índios cercados

As famílias de colonos há metros de distância

incou os óculos redondos no rosto

e os funcionários viraram as armas para o chão

diante da mímica apaziguadora

Vargas se colocou em frente ao chefe

com o cocar maior de todos

e estendeu o braço

em saudação

Aceitou o ramo de folhas

que todos eles traziam nas mãos

com muitas reverências

e fez um gesto para que os funcionários

se aproximassem de volta 
Ao invés das armas

traziam ferramentas da companhia

enxadas foices e machados

que foram

depositados nos braços dos nativos

Vargas cobriu o gesto com palavras solenes

ecoando pela caixa de som

e convidou os novos trabalhadores da pátria

a acompanharem o resto da celebração

Além de registrar a cena

em que o conselheiro do governador Konder

sem o papagaio no ombro pregou o brasão no peito de Vitorino

e a surpresa do casal de colonos

o ser presenteado com um cavalo da caravana

fotógrafo

ambém foi ligeiro

o capturar o momento em que o notável Vargas

vestindo o fraque com gravata borboleta

característico

egou o ramo de folhas na mão

estendeu ao alto

para sempre 


\section{I5.92 A última migalha}

Já era a segunda vez

que Morena enchia a pazinha

com os pedaços que descolavam

de Vó Alma

e despejava no pote

$$
\text { da despensa }
$$

Desde que sentou na cadeira

ao lado do fogão de ferro

olhando pra a cabeceira da mesa

de canela velha

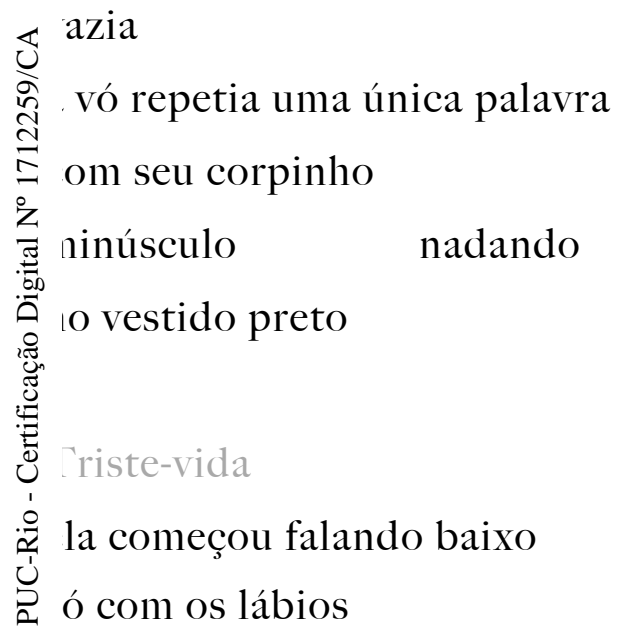

Os passarinhos do terreiro

continuavam

\section{bem-te-vi}

Triste-vida a vó respondia

bem-te-vi

triste-vida

bem-te-vi 
O telefone tocava sem parar

e Morena trazia os recados

dos parentes

dos filhos distantes

a até do prefeito

que apesar de lembrar de Vó Alma

quis falar mesmo

com Pai Vitório

antes do velório

no seu gabinete

bem-te-vi

triste-vida

bem-te-vi

triste-vida

3

triste-vida

|| Foi confirmada a chegada dos 2 ônibus na cidade durante a madrugada com cerca de I50 ndios Todos eles vivem em reservas de cidades vizinhas e irão acompanhar o movimento le demarcação das terras A prefeitura espera mais reforços deste tipo até a parte da tarde uando a ofensiva do grupo será realizada O momento é considerado o mais tenso da lisputa da área III

Morena ouvia o plantão de canto

de orelha

retirando o café da mesa

Quando percebeu que tinha

colocado o prato e a caneca de plástico

gasto na cabeceira

seus olhos rasgados

correram rios

revoltosos 
Não havia represa que segurasse

aquela corredeira

inundando o rosto redondo

de Morena

Os soluços quebravam na beira

do quarto de Mãe Clara

que costurava o botão

do meu uniforme

O duelo entre as águas barrentas

e a terra seca ecoava

pela casa

$((((((()))))))$

triste-vida

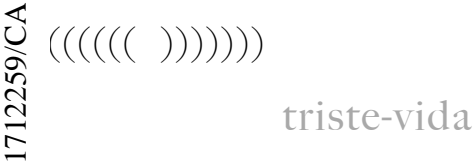

$(((((()))))))$

triste-vida

串

Ios pés da cadeira de Vó Alma

o monte de migalhas

ão tinha fim

Morena secou os olhos

na barra da blusa

destapando o barrigão

e pegou a vassoura

fungando

Vó Alma se pendurou no assento

de palha

e desceu pelas pernas de madeira

seguindo os passos da empregada

até a despensa 
Pequena

do tamanho de uma única

migalha

Vó Alma espiou

as nádegas volumosas

as dobras novas

que colavam na blusa

e os braços roliços

metidos dentro

do pote

\section{Que vergonheira}

Marilene Vitória das Neves

se aproveitando

da gente

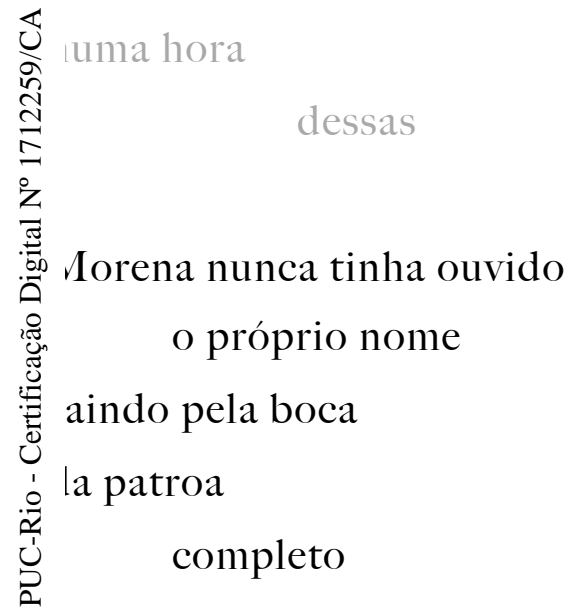

Antes de sair pela porta

pra nunca mais voltar

ela deixou os potes cheios

com todos os pedaços de Vó Alma

na cabeceira

da mesa de canela

velha

sem as tampas 


\section{Nota 15}

Ao final do último dia de entrevistas, faria uma varredura pelo Bairro da Gruta com a ajuda de Êlo. Seria nossa tentativa final de encontrar a cabana do senhor indígena. Percorremos todas as ruas e fomos parar em frente ao jardim da casa amarela, caminho que costumávamos fazer juntos. Sondamos a moradora da casa vizinha sobre um indígena, rituais suspeitos e um incêndio. Embora não tivesse visto nada daquilo, ela conhecia Seu Salvador. Seguindo as instruções, paramos na porta de uma casa que passei em frente diversas vezes durante as visitas aos caboclos. Um casal estava na varanda. Perguntei por Salvador e ele confirmou com a cabeça. Tio Salvador tinha um aspecto abatido por conta da doença, parecido ao de minha mãe. Na medida em que lhe falava sobre o senhor indígena, a cabana, o caderno, sua expressão ficava mais espantada. De tudo aquilo, a nica coisa que podia dizer que era verdade, era a existência de Andreza. De fato a onhecia, mas não tinham quase nenhum contato. Andreza era casada com o seu sobrinho pouco sabia da vida dela. Muito menos que era chamado, com tanta intimidade, de Tio alvador.

or mais que o final da história do senhor indígena, escolhido por Andreza, lembrasse a norte do narrador - de uma sala asséptica de UTI diretamente para a cova, era inegável ue a minha narradora possuía a mesma a autoridade daqueles que têm algo a dizer no ito de morte. E ao que parecia, solicitava a mim que desse continuidade à narrativa través do caderno imaginário do senhor indígena com que me seduzia dia após dia. Além de me sugerir, indiretamente - ou por vias ocultas - que eu levasse as transcrições das entrevistas que fiz com os caboclos para o museu da cidade. Através do paralelo que se cumpria, agora, com a entrega do caderno do senhor indígena ao arquivo regional de Chapecó, que eu esperava tanto fazer. 
No último final de semana antes de voltar para o Rio de Janeiro, passei por Chapecó para a festa na casa Ilé Asè Aféfé t'Oyá. O terreiro ficava em um bairro afastado do centro, onde só se chegava de carro. Quando cheguei, a gira já havia começado e a casa estava cheia. Luiz Carlos estava todo vestido de branco e tinha os cabelos enrolados em um enorme turbante. Além de desempenhar a função de ekedi, tomando conta dos médiuns do terreiro, era namorado do dirigente da casa. Diego, um rapaz surpreendentemente jovem, se apresentou a todos com o nome da entidade que regia a casa, o Caboclo Pena Dourada. Ao final da noite, conversamos sobre a intrigante história da casa de encantaria. Filho de pais umbandistas, Diego se tornou médium muito cedo. No seu trabalho com as entidades espirituais, recebeu a instrução de uma delas para fundar uma casa de encantaria. Surpreso com a demanda do seu santo, como dizia, pediu aconselhamento ao dirigente da casa a que pertencia. Depois de algumas consultas, descobriu que a entidade espiritual que o acompanhava era um caboclo encantado - e não uma entidade espiritual da umbanda. Foi lele que recebeu todas as diretrizes para fundar uma casa de encantaria em plena Chapecó. iem nunca ter ido a uma canjira de encantados do Maranhão, Diego conduzia o culto da ncantaria no Oeste de Santa Catarina dentro de toda a ritualística da religião. A prática o terreiro, que também já estava presente neste trabalho como busca de expansão da zitura da história de fundação da cidade para dimensões imateriais através de outras ógicas de pensamento, aparecia materializada na fundação da casa Ilé Asè Aféfé t'Oyá. ista reinvenção de outro tempo/espaço, transcendente às dimensões físicas, que o terreiro ambém é capaz, apresentava-se como a própria operação de reinvenção da geografia da idade - aproximando Caibi e Iraí. Além disso, a aliança entre Diego e o caboclo encantado também sugeria que elos e cruzamentos com outras ontologias possibilitam reinventar as histórias que vem junto com o nosso nome. Ao invés de renunciar à história dos antepassados, então era possível reinventá-la a partir de outras ancestralidades. 


\section{O desfile}

A fila de moradores fazia zigue-zague

da porta de entrada

da casa mortuária

até a esquina

A migalha pequena de Vó Alma

ganhou uma cadeira

com almofadas

na cabeceira do

alaúde

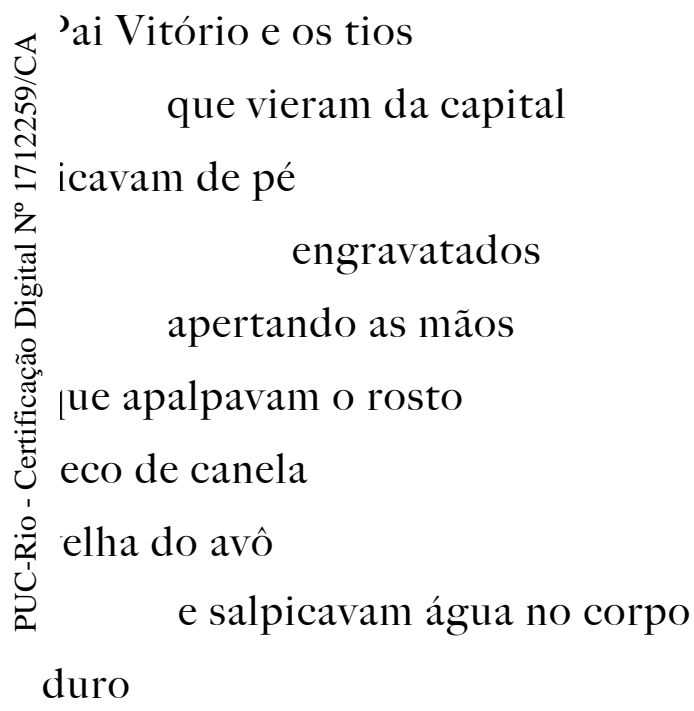

molhando o ramo de folhas

no copinho

Mas nem com toda água

das lágrimas Avô Ino amoleceu 
O prefeito de óculos escuros

chamou Pai Vitório ao lado

do púlpito

as coroas de flores com faixas ao fundo

e fez um discurso

com aquelas subidas

e paradas na voz

que Pai Vitório treinava

na frente do espelho

Nunca antes o nome de Avô Ino

tinha sido tão bem

dito

pra tanta gente

A única maneira

ญ le pagar o trabalho do avô

ป $a$ mesma moeda

) prefeito disse

com a mão no ombro

屏 le Pai Vitório

ra batizando a rua

le casa

先

de Vitorino

O carro alegórico saiu

do lado do cemitério

com os moradores vestindo trajes

pretos

até a rua do Progresso 
$\mathrm{Na}$ carroceria

os bandeirantes continuavam

com as mesmas

botas

chapéus

e carabinas

deitadas no ombro

A rainha de folhas verdes

com vestido brilhante

e penteado armado

segurava a bandeira com as

luvas compridas

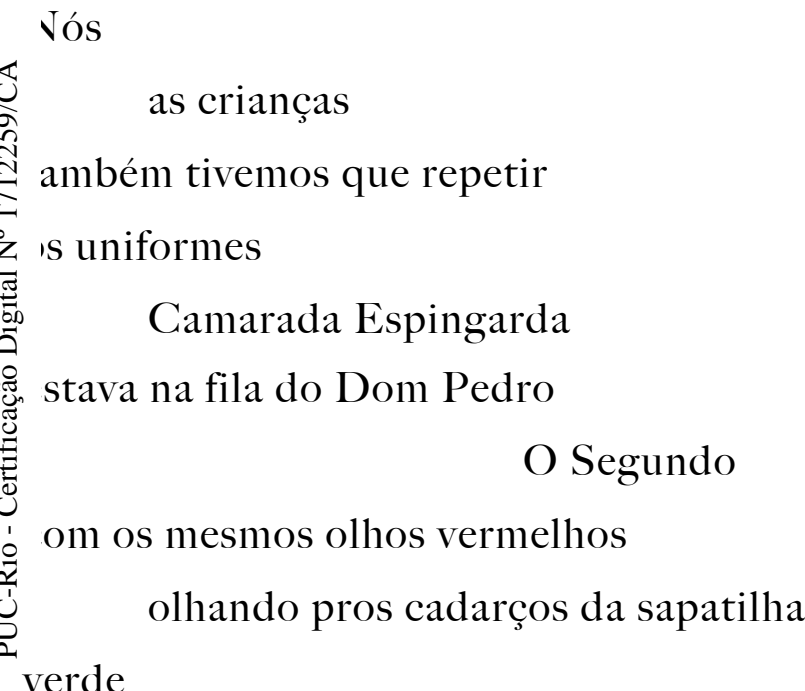

e a saia que

detestava

O prefeito passou a pistola

pra Pai Vitório apertar

o gatilho 
A banda municipal

tremeu os pratos

os trompetes gritaram e os tambores

vibraram

$$
((((((()))))))
$$

por baixo da terra

fazendo os joelhos

dobrarem automáticos

O carro alegórico avançou

balançando faixas e palmeiras

como se um ímã poderoso

uxasse os pneus

ठ0

) foguetório espantava os pássaros

nas as pisadas fortes

estalando no asfalto

总o mesmo tempo

营 aziam a pequena Folhas Verdes

'arecer uma

党

nação

No canteiro central da praça

nenhum índio à vista pelo gramado

as barracas de lona preta

fechadas 
O carro dobrou

na esquina e entrou pela calçada

coberta de flores até o coreto

Com vista

distante pra estátua de Getúlio Vargas

as caixas de som do caminhão

soltaram o hino nacional

Do prefeito

aos colonos antigos

e os seus filhos

fantasiados de bandeirantes

até os caboclos metidos

no meio da multidão

Todos cantarolavam

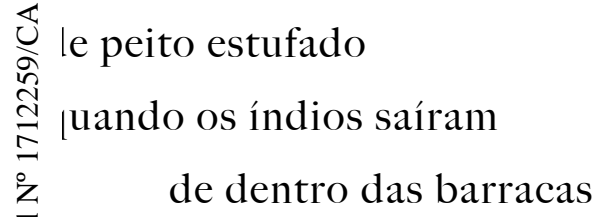

em número multiplicado

$m$ direção

os moradores

Jomo uma onda

gigantesca

das águas barrentas do rio Uruguai

os índios avançaram pela multidão

gritos estalos e pisadas

tomando o carro

alegórico 
Em um instante

o caminhão ficou depenado

faixas e palmeiras abaixo

Os bandeirantes estirados

no tablado de madeira

sem as suas carabinas

Alguns sem

chapéu

O grupo de índios

maior que a multidão

da pequena cidade

seguiu com as carabinas deitadas

no ombro

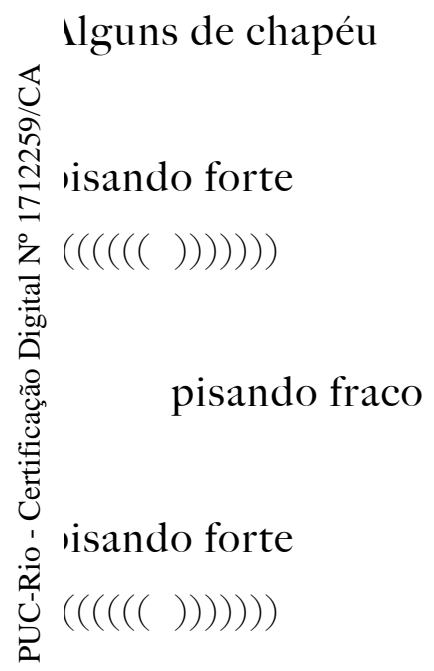

pisando fraco

A bandeira da rainha

empunhada por uma das mãos

morenas no início da fila

tremulava

pelas ruas do centro

até o bairro de

baixo

as viaturas de polícia sempre ao lado

alguns moradores seguindo de longe 
Quando a grande cobra

indiana chegou no parque florestal

um deles sacou o mapa das terras

como se fosse um agrimensor

Seguido por um grupo menor

com enxadas e taquaras na mão

dava passos largos

parando a cada metro

o dedo indicando o ponto exato

onde eram

fincados os marcos

da nova fronteira

) líder de todos

ङ estindo a mesma pele de onça

os ombros

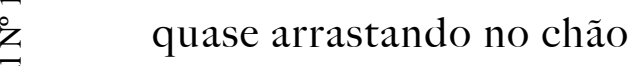

Lão fosse o rabo

cortado

rela metade

ecebeu o cabo da bandeira

또․

ù cravou no chão

da antiga terra

onde as folhas eram diferentes

das árvores plantadas

nos canteiros

da praça 
A nuvem verde de maritacas

passou riscando o céu

com a gritaria doida

que logo desapareceu

dos ouvidos de todos

mas que ficaria bem guardada

no meio das folhas

do meu caderno de couro 


\section{Nota Final}

Com a chegada da pandemia, meus planos de voltar para Iraí e entrevistar o grupo indígena Kaigang foram descartados. Depois de meses de isolamento, fui passar duas semana em uma cabana na região serrana do Rio, na estrada de Macaé de Cima. A proprietária, Sandra, era uma cabocla vinda do Maranhão e que recentemente havia conseguido comprar um lote de terras no Sítio Terra Clara. Aqui, levantara uma cabana de pau-a-pique com uma cozinha de chão batido, onde vinha tomar chimarrão e contar causos - enquanto meu sotaque nasalado voltava. Este hábito, que recuperei depois da viagem, ela também mantinha pelos anos que passara no Rio Grande do Sul. Sandra era fardada no Santo Daime, como é chamada esta expressão religiosa, surgida na região amazônica, que faz uso do ayahuasca. A igreja que ela costumava frequentar, ao lado do sítio, faz um ruzamento entre a doutrina do Norte e a umbanda carioca, em um culto chamado mbandaime. Esta reinvenção característica da prática de terreiro, em que os diferentes nundos se uniram em uma nova prática - combinando ritualísticas, hierarquias e egrégoras foi instruída pela entidade espiritual do Caboclo Tupinambá. Para quem Sandra vivia antando no meio do seu reinado, como costuma se referir à plantação de rainhas que spalhou pelas suas terras. Estas plantas, cujas folhas são usadas na feitura do chá da yahuasca, são consideradas a porção feminina da bebida enteógena. Sempre combinada o cipó-mariri, parte masculina da alquimia. Ao final da segunda semana, antes de voltar ara o Rio de Janeiro, Sandra ofereceu a sua própria casa para alugar. Estas últimas linhas que escrevo repetem não apenas o deslocamento idêntico ao dos sonhos, que permeou a experiência da viagem e retorna em uma tentativa de narrá-la. Em setembro do ano passado, me mudei para o sítio. A antiga casa de Sandra é tomada por trepadeiras e cercada de uma floresta tão densa quanto o sertão verde que rodeava as colônias do Oeste catarinense. A região pertence ao distrito de Nova Friburgo e, na primeira visita à cidade, fundada por imigrantes suíços, vislumbrei a expansão dos limites da leitura que vinha fazendo sobre a história de fundação. Em constante transe, a escrita do Baile da onça acabava de cruzar os pontos entre a cidade ficcional do romance, as ruas de nomes suíços que circundam a praça central e a estátua de Getúlio Vargas. Estas últimas linhas que escrevo também são as primeiras deste caderno de notas. No mesmo dia $\mathrm{I}^{\circ}$ de abril, há dois anos, eu começava uma missão de estudos em busca dos caboclos da minha terra natal, ao mesmo tempo em que era, por eles, levado. E do mesmo modo que meu corpo dançou e foi 
dançado na roda do bailado, prefigurando a prática desta escrita e a forma aberta desta narrativa que abre buracos e se espalha pelo território de fundação da cidade - assim, também, concluo. Fechando e abrindo este trabalho, exatamente como são os dizeres que costumam encerrar os rituais da Arca da Montanha Azul - este trabalho está fechado e aberto para sempre.

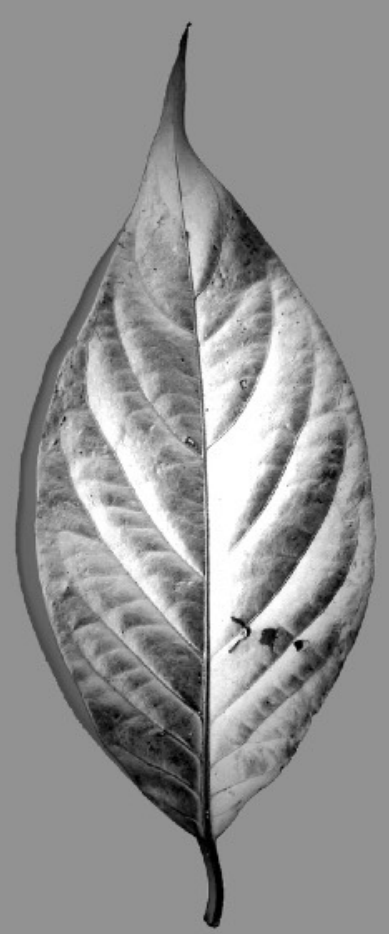


5

\section{Referências bibliográficas}

AIRA, César. Um acontecimento na vida do pintor-viajante. Trad. Paulo Andrade Lemos. Rio de Janeiro: Nova Fronteira, 2006.

ALBUQUERQUE, Fernanda Farias de. A princesa: a história do travesti brasileiro na Europa

escrita por um dos líderes da Brigada Vermelha. Trad. Elisa Byington. Rio de Janeiro: Nova Fronteira, 1995.

ANDRADE, Drummond. Menino antigo - Boitempo II. Rio de Janeiro: José Olympio, 1974.

ARANHA, Graça. Canaã. Rio de Janeiro: Nova Fronteira, 1982.

ANDERSON. Benedict. Comunidades imaginadas: reflexões sobre a origem e a difusão do nacionalismo. São Paulo: Companhia de Letras, 2008.

ANDRADE, Mário de Andrade. Macunaíma: o herói sem nenhum caráter. $33^{\mathrm{a}}$ Ed. Belo Horizonte/Rio de Janeiro: Livraria Garnier, 2004.

. O turista aprendiz. São Paulo: Duas Cidades, Secretaria da Cultura, Ciência e Tecnologia, 1976.

ALENCAR, José De. Iracema: lenda do Ceará. São Paulo: Klick Editora, s/d. . O Guarani. São Paulo: Klick Editora, s/d. . Ubirajara. $1^{\text {a }}$ Ed. São Paulo: Grua, 2015.

BÂ, Amadou Hampâté. Amkoullel, o menino fula. Trad. Xina Smith e Vasconcellos. $3^{\text {a }}$ Ed. São Paulo: Palas Athena: Acervo África, 2013.

BARTHES, Roland. Mitologias. Trad. Rita Buongermino e Pedro de Souza. 10. ed. Rio de Janeiro: Bertrand Brasil, 1999. 192p.

BENJAMIN, Walter. A doutrina das semelhanças. In: Magia e técnica, arte e política: ensaios sobre literatura e história da cultura. Trad. Sérgio Paulo Rouanet. 7. ed. São Paulo: Brasiliense, 1994. p. 108-113. 
. A imagem de Proust. In: Magia e técnica, arte e política: ensaios sobre literatura e história da cultura. Trad. Sérgio Paulo Rouanet. 7. ed. São Paulo: Brasiliense, 1994. p. 36-49.

BENJAMIN, Walter. Desempacotando a minha biblioteca. In: Obras escolhidas II. Rua de mão única. Trad. Rubens Rodrigues Torres Filho; José Carlos Martins Barbosa. São Paulo: Editora Brasiliense S.A., 2000. p.227-235.

. Mendigos e prostitutas. In: Obras escolhidas II. Rua de mão única. Trad. Rubens Rodrigues Torres Filho; José Carlos Martins Barbosa. São Paulo: Editora Brasiliense S.A., 2000. p.125-127.

. Prefácio - Walter Benjamin ou a história aberta. Jeanne Marie Gagnebin. In: Magia e técnica, arte e politica: ensaios sobre literatura e história da cultura. Trad. Sérgio Paulo Rouanet. 7. ed. São Paulo: Brasiliense, 1994. p. 7-20.

. Sobre o conceito de história. In: Magia e técnica, arte e politica: ensaios sobre literatura e história da cultura. Trad. Sérgio Paulo Rouanet. 7. ed. São Paulo: Brasiliense, 1994. p. 222-232.

. O narrador. In: In: Magia e técnica, arte e política: ensaios sobre literatura e história da cultura. Trad. Sérgio Paulo Rouanet. 7. ed. São Paulo: Brasiliense, 1994. p. 197-221.

BOPP, Raul. Poesia Completa. Org. Augusto Massi. 2 Ed. Rio de Janeiro: José Olympio, 2013.

BHABHA. Homi. O local da cultura. Belo Horizonte: UFMG, 1998.

CEOM. A viagem de 1929: Oeste de Santa Catarina, documentos e leituras. Contém fac-similar de O Oeste catharinense / Arthur Ferreira da Costa e o Oeste catharinense / José Arthur Boiteux. Chapecó: Argos, 2005. 207p.

. A voz de Chapecó: artigos de Antonio Selistre de Campos - 1939 a 1952. Chapecó: Argos, 2004. 259p.

CALLADO, Antônio. Quarup. São Paulo: Círculo do livro, s/d.

CARBONERA, Mirian. SCHMITZ, Pedro Ignacio (Orgs.). Antes do oeste catarinense: arqueologia dos povos indígenas. Chapecó: Argos, 2011. 364p.

CASTRO, Sílvio. A carta de Pero Vaz de Caminha. Porto Alegre: L\&PM, 2017.160p. 
CLASTRES, Pierre. A sociedade contra o estado. Trad. Theo Santiago. São Paulo: Ubu Editora, 2017.

COCCIA, Emanuele. Metamorfoses. Trad. Madeleine Deschamps e Victoria Mouawad. $1^{\text {a }}$ Ed. Rio de Janeiro: Dantes Editora, 2020.

COELHO, Alexandra Lucas. Deus-dará: sete dias na vida de São Sebastião do Rio de Janeiro, ou o apocalipse segundo Lucas, Judite, Zaca, Tristão, Inês, Gabriel \& Noé. $1^{\text {a }}$ Ed. Rio de Janeiro: Bazar do Tempo, 2019.

CUNHA, Manuela Carneiro da. Índios no Brasil: história, direitos e cidadania. São Paulo: Claro Enigma, 2012.

COETZEE, J.M. À espera dos bárbaros. Trad. José Rubens Siqueira. São Paulo: Companhia das Letras, 2006.

. Elizabeth Costello: oito palestras. Trad. José Rubens Siqueira. São Paulo: Companhia das Letras, 2004.

DELEUZE, Gilles; GUATARRI, Félix. Devir intenso, devir-animal, devirimperceptível. In: Mil platôs: capitalismo e esquizofrenia 2, vol. 4. Trad.

Suely Rolnik. 2a Ed. São Paulo: Editora 34, 2012.

DERRIDA, Jacques. Espectros de Marx: O Estado da divida, o trabalho do luto e a nova Internacional. Trad. Anamaria Skinner. Rio de Janeiro: Relume Dará, 1994.

. Mal de Arquivo: Uma impressão Freudiana. Trad. Claudia de Moraes Rego. Rio de Janeiro: Relume Dará, 2001.

DIDI-HUBERMAN, Georges. A imagem sobrevivente: história de arte e tempo dos fantasmas segundo Aby Warburg. Trad. Vero Ribeiro. Rio de Janeiro: Contraponto, 2013.

DIWAN, Pietra. Raça pura: uma história da eugenia no Brasil e no mundo. $2^{\mathrm{a}}$ ed. São Paulo: Contexto, 2018.

DO RIO, João. A alma encantadora das ruas. Org. Raúl Antelo. São Paulo:

Companhia das Letras, 1997.

EIDT, Paulino. Os sinos se dobram por Alfredo. 2. ed. Chapecó: Argos, 2016. $376 p$.

FAUSTO, Boris. História do Brasil. 14 Ed. São Paulo: Editora da Universidade de São Paulo, 2015. 
FERRAZ, Marina Cristina Franco. Graça, corpo e consciência. Revista Famecos: mídia, cultura e tecnologia. Porto Alegre, v. 18, n. 3, p. 674-684. Set./Dez. 2011.

FIGUEIREDO, Isabela. Caderno de memórias coloniais. São Paulo: Todavia, 2018 .

FISCHER, Martin. Iraí: Cidade Saúde - Trechos característicos de sua história. Ijuí: Livraria e tipografia Progresso, 1954.

FOUCAULT, Michel. A vida dos homens infames. In: . Estratégias de poder-saber. Ditos e escritos. Vol. IV. Rio de Janeiro: Forense universitária, 2003.

FREUD, Sigmund. O mal-estar na civilização, novas conferências introdutórias à psicanálise e outros textos (1930-1936). Trad. Paulo César de Souza. São Paulo: Companhia das Letras, 2010.

FRANZINA, Emilio. A grande emigração: o êxodo dos italianos do Vêneto para o Brasil. Trad. Edilene Toledo, Luigi Biondi. Campinas: UNICAMP, 2006.

GUIMARÃES, Manoel Luiz Salgado. Historiografia e nação no Brasil. Rio de Janeiro: EDUERJ, 2011.

KOPENAWA, Davi; ALBERT, Bruce. A queda do céu: palavras de um xamã yanomami. Trad. Beatriz Perrone-Moisés. 1. Ed. São Paulo: Companhia das Letras, 2015.

LAS CASAS, Frei Bartolomé de. Paraído destruído. Porto Alegre: L\&PM Editores Ltda, 1984.

MARQUETTI, Délcio. Bandidos, forasteiros e intrusos: história do crime no oeste catarinense na primeira metade do século XX. Chapecó: Argos, 2008.

MIGNOLO, Walter. Desobediência epidêmica: a opção descolonizar e o significado de identidade em política. Revista Gragoatá, n. 22, p. 11-41, $1^{\circ}$ Sem. 2007. Trad. Ângela Lopes Neto.

MISHIMA, Yukio. Confissões de uma máscara. São Paulo: Círculo do livro, s/d. MONTAIGNE, Michel de. Os ensaios: uma seleção. trad. Rosa Freire d'Aguiar. São Paulo: Companhia da Letras, 2010.

MUSSA, Alberto. Meu destino é ser onça. Rio de Janeiro: Record, 2009.

NACKE, Aneliese...[et al.] Os Kaigang no oeste catarinense: tradição e atualidade. Chapecó: Argos, 2007. 158p. 
NANCY, Jean-Luc. Corpo, fora. Trad. Marcia Sá Cavalcane Schuback. Rio de Janeiro: 7Letras, 2013.

NARBY, Jeremy. A serpente cósmica: o DNA e as origens do saber. Rio de Janeiro: Dantes, 2018.

ONDJAKI. AvóDezanove e o segredo do soviético. São Paulo: Companhia das Letras, 2009.

OZ, Amós. Pantera no porão. Trad. Milton Lando e Isa Maria Lando. São Paulo: Companhia das Letras, 1999.

RENK, Arlene. A luta da erva: um oficio étnico da nação brasileira no Oeste catarinense. 2. ed. Chapecó: Argos, 2006. 250p.

RIBEIRO, Darcy. Maíra. São Paulo: Círculo do Livro S.A, s/d.

ROSA, João Guimarães. Meu tio o Iauaretê. In: Estas estórias. 7 ed. Rio de Janeiro: Nova Fronteira, 2015.

SÁ, Lúcia. Literaturas da floresta: textos amazônicos e cultura latino-americana. Rio de Janeiro: EdUERJ, 2012.

SANTIAGO, Silviano. Por que e para que viaja o europeu? In: Nas malhas da letra: ensaios. Rio de Janeiro: Rocco, 2002. 221-240p.

. Stella Manhattan. Rio de Janeiro: Nova Fronteira, 1985.

SCOTT, Paulo. Habitante irreal. Rio de Janeiro: Objetiva, 2011.

SCHOØLLHAMMER, Karl Erik. O olhar antropológico e o fim ou O fim do exótico. In: Além do visível: o olhar da literatura. Rio de Janeiro: 7Letras, 2007. p. 174.

SIMAS, Luiz Antonio. Caboclo: supravivente e antinomia da civilidade. In: $A$ ciência encantada das macumbas.1 ed. Rio de Janeiro: Mórula, 2018. 124 p.

SIMON, Mário. Os sete povos das missões: trágica experiência. 3 Ed. Porto Alegre: Martins Livreiro, 1993.

SOMMER, Doris. Ficções de fundação: os romances nacionais da América Latina. Trad. Gláucia Renate Gonçalves e Eliana Lourenço de Lima Reis. Belo Horizonte: Editora UFMG, 2004. 488p.

STIGGER, Veronica. Opisanie Swiata. São Paulo: Cosac Naif, 2013. 
TAYLOR, Diana. O arquivo e o repertório: Performance e memória cultural nas Américas.Trad. Eliana Lourenço de Lima Reis. Belo Horizonte: Editora UFMG, 2013.

VALENTINI, Delmir José. Da cidade santa à corte celeste: memórias de sertanejos e a Guerra do Contestado. $4^{\mathrm{a}}$ ed. Chapecó: Argos, 2016. 256p.

Vianna, Hermano. O mistério do samba. Rio de Janeiro: Jorge Zahar Editora. Editora UFRJ, 1995.

VICENZI, Renilda. Mito e história na colonização do Oeste catarinense. Chapecó: Argos, 2008. 162p.

VILAÇA, Aparecida. Paletó e eu: memórias de meu pai indígena. São Paulo: Todavia, 2018.

WERLANG, Alceu Antonio. Disputas e ocupação do espaço no Oeste catarinense: a atuação da Companhia Territorial Sul Brasil. Chapecó: Argos, 2006.149p.

VIVEIROS DE CASTRO, Eduardo. A inconstância da alma selvagem e outros ensaios de antropologia. São Paulo: Ubu Editora, 2017.

PRANDI, Reginaldo. Caboclos e pretos-velhos da Umbanda. In: Encantaria brasileira: o livro dos mestres, caboclos e encantados. Rio de Janeiro: Pallas, 2011.

. Entre caboclos e encantados: mudanças recentes em cultos de caboclo na perspectiva de um chefe de terreiro. In: Encantaria brasileira: o livro dos mestres, caboclos e encantados. Rio de Janeiro: Pallas, 2011.

RENAN, Ernest. $O$ que é uma nação? In: Nacionalidade em questão. Rio de Janeiro: Caderno da Pós Letras. n. 19. UERJ, 1997.

RIZZI, Dominga Ana. Caibi: histórias e memórias. Caibi: Prefeitura Municipal de Caibi, 2012.

RODRIGUES, João Barbosa. Mbaé Kaá: o que tem na mata: Tapyiyeta Enoyndaua: a botânica nomenclatura indígena. 2 Ed. Rio de Janeiro: Dantes, 2018.

SCHWARCZ, Lilia Moritz. As barbas do imperador: D. Pedro II, um monarca nos trópicos. São Paulo: Cia da Letras, 1998. 
O espetáculo das raças: cientistas, instituições e questão racial no Brasil-1870-1930. São Paulo: Companhia das Letras, 1993.

STEPAN NL. A hora da eugenia: raça, gênero e nação na américa latina. Rio de Janeiro: Editora Fiocruz; 2005.

\section{Páginas consultadas na internet}

Disponível em: <http://pepsic.bvsalud.org/pdf/bapp/v29n2/v29n2a03.pdf $>$ Acesso em: 17 mar. 2021.

Disponível em: <https://www.caibi.sc.gov.br>. Acesso em: 17 mar. 2021.

Disponível em: $<$ https://www.youtube.com/watch

v=CoxjVFfvI7g\&list=RDCoxjVFfvI7g\&start_radio=1 $>$ Acesso em: 17 mar. 2021.

Disponível em: < https://www2.senado.leg.br/bdsf/bitstream/handle/id/188899/

Tratado $\% 20 \mathrm{da} \% 20$ terra $\% 20 \mathrm{do} \% 20$ Brasil.pdf? sequence=1>Acesso em: 17 mar. 2021.

Disponível em: <http://www2.senado.leg.br/bdsf/handle/id/242428> Acesso: 17 mar. 2021.

Disponível em: <https://cimi.org.br> Acesso: 17 mar. 2021.

Disponível em: <http://www.funai.gov.br> Acesso: 17 mar. 2021.

Disponível em: <https://www.jstor.org/stable/20137096?

seq=1\#page_scan_tab_contents $>$ Acesso: 17 mar. 2021. 


\section{Anexos}

Transcrições de trechos das entrevistas com os caboclos da cidade.

\section{[Entrevistado: Orides Ramon]}

E fiquêmo ali e fui um pioneiro aí e sempre fiquei e tô aí até hoje, né? Que isso aí era tudo mato. Isso era sertão de mato. De noite tinha... botava feixe de lenha [inaudível], porque tinha onça naquele tempo.Ah vimo, só nunca matêmo. Mas eu conheço onça andando. Naquele tempo facilitava, andava, baixou aquela serração... ah! Cuidado que o bicho... Só tinha que cuidar. Naquele tempo lá, cachorro a gente sempre tinha, até 10 . O bicho era... pra cuidá, né? O negócio não era fácil. Mas a gente, depois foi limpando, fazendo um devasso pra cá e pra lá, foi ficando grande. Má árvore não se derrubava, só roçava por baixo. Naquele tempo lá ninguém derrubava o mato assim, cuidava... E se criêmo ali, né? Tinha aquele bugio branco, que muitos nem conhecem, né? Aquele avançava, daí tinha que cuidar as irmã quando iam lavá no Pindó lavá a roupa, tinha que ficar lá cuidando. Porque ele vem de pé, assim, o branco... aquele, o bugio branco, conheço até aquele. Agora, aquele amarelo a gente matava pra comer assado. Assava e comia. Ô, mais deuzulivre hôme, aquilo lá era paca, era viado, era tatu, era cotia... Era o que vinha sempre tinha... Tinha aquilo que te estorvava, né? Tu saía sem cachorro ali tu já via um lá já...ia pega uma carne nova lá e pá! Já... era à vontade hôme. Peixe, peixe Dirlei... abria aquelas vereda de sol assim que pegava na água tu ia com a espingarda achava aquelas trairona dormindo, assim, chegava... pãm! Já tinha uma pra... Nóis vivia só da... nóis não sabia o que era comer carne de porco e de gado. Era só de caça. Se criêmo, se criêmo! Má também não tinha uma doença, não tinha nada! Cara ficava... Nóis fiquêmo ali que nem cerno.

\section{[Entrevistado: Adão Cardozo e Hercílio Cardozo]}

[Hercílio: Carcula os que entraram primeiro por aí, era Sertão.] Sertania, sertania. Sertão. Era um sertão. Eu não sei, hôme, pra ir ali no Iraí, passar pra lá, se tinha 
arguma ponte. Isso eu não me alembro. Mas tinha que ter, né? Uma coisa pra eles passar pra lá. [Hercílio: Eu acho que passavam de caíque, tio.] É, né. E animal passavam à nado. Como é que iam passá? Iam buscar, porque pra lá já tinham mais coisa, né? Porque já ia pegando pra banda lá da fronteira, né? Aberto, ali, pra lá. Aparecia, aparecia. Alguns já existia, a bugradinha. [Hercílio: Eu me lembro quando nóis morava ali na querência véia, ali embaixo, na [inaudível] ali, tinha os pé de bergamoteira grande na frente da casa, assim, pro lado de baixo, mais pro lado de baixo era estrada. Eles vinham se acampavam ali pra trabaiá, sabe? Pra fazer as...] Fazer cesto. [Hercílio: As peneira, chegavam e pediam, sabe? Daí conversavam com o pai e a mãe. Eu tinha 8, 9 ano. - Mas não compadre, o pai dizia pra eles. Pode ficar à vontade aí. - Tão com fome? Têmo coisa aí pra comer. Tinha, ele diziam. Se acampavam ali, ficavam 2, 3 dia ali, fazia o trabalho deles, às vêiz até uma semana. Incomodavam niguém. (inaudível) Ficavam ali. O pai tinha um galpãozinho do lado de baixo. Más ó, ficava uma semana, o tempo não corria que nem agora. Podem fazerem fogo ali aquele galpãozinho. Pode se acomodá ali, pode trabaiá. (inaudível)]. Ah não, ele iam mesmo, tiravam. É, e era ãnsim aquela época. [Hercílio: Existia... Não era...era arguns, né? Eles passavam ali. Mesma coisa que nem agora eles passam vendendo o material deles ãnsim, até hoje, né? De bicicreta, ônibus, que às vêiz não tem um carrinho. Dificilmente... eles gostam de andar de a pé.]. De a pé e trabaiando. Acampá assim no mato. [Hercílio: Mas tinha, tinha sim.]

\section{[Entrevistado: Adão Cardozo e Hercílio Cardozo]}

[Hercílio: Lembra das balsa, tio?]. Más credo. [Hercílio: Pois é, nóis falêmo um pouco com esse rapaiz aí também]. Fazia prazer de viajar pra São Borja hoje, ainda. Ô, mas eu andava à cavalo em cima daquelas madêra lá. Más eu era rapaizote. Primeiro trabaio que eu comecei a trabaiá, aquelas prancha... era 12 polegada. Fazê os môio de prancha. Caminhonada de prancha, daí prensava, botava tudo num monte e daí fazia os môio de prancha, né? Amarrava bem amarrado e jogava na água, daí ia... [Hercílio: Aquele tipo remorque, né?]. É, remorque, barsa muque. Ah tá loco, hôme! É um rolo de... assim. Tu bota elas, 
amarra mais ou menos assim, em cima uma da outra e vai continuando. Ah, não perdia tempo. Mais ou meno 8 ou 9 dia. Se saía aqui de Mondaí tava lá em São Borja. Só parava quando o tempo, ãnsim, tava... perigoso, né? Comida sobrava... em cima, levava o campamento sortido. Saía daí e dinheiro levava prá comprar, né? Tinha o caíque, sempre. Senão ia com uma lancha lá. Os boteco fora lá comprar. Ah, se chovia, tinha a casa em cima da madeira. Duas casa. [Hercílio: E era uma parada pra descanso, né?] É, às vêiz mêsmo até pra dormir, às vêiz a turma tavam cansado. [Hercílio: Atava lá...] E noutro dia demadrugadinha soltava a bicha... e alinhava de novo. Lá eles vendiam lá, não sei pra quem. Entregava lá e eles se viravam. Outra firma pegava. Ganhava mil e cem, mas era dinheiro, né? [Ganhava por viagem?]. Por viagem. Bá, hôme, era um monte de dinheiro na época. É... não era fácil. E depois o mais perigo, que nem, ali tem o sarto grande, né? Hôme do céu, aqui não tem nada que iguala aquilo lá. Aquilo de longe você enxergava aquelas ovêia branqueando ${ }^{38}$. O remórque que caía... bão, a lancha tinha tanto de entra que sortava o remórque. Sortava ali e costeava, né? [Hercílio: Porque não dava pra ela seguir. A balsa descia naquele canal ali. As ovelha que ele tá dizendo, o senhor tá entendendo que é as maré? Que nem daqui, lá você já via. Parece um bando de ovelha].

\section{[Entrevistada: Generosa Borges dos Santos]}

Muitas vêiz nóis fumo lá na Linha Glória, lá no Miro Turcato, acho que foi. Chegou um ponto que ele não queria fazer mais rancho pra nóis. E nóis trabaiando na roça. O meu marido diz - Tu faz o rancho e depois quando nóis coiê, aí nóis acertêmo, daí nóis vamo pagá o mercado. E foi, foi que ele não queria mais fazer rancho e nóis comendo mandioca pura, cozida. Tinha os pai dele vivo também, má era ele que mandava na terra. Aí nóis tinha o soja maduro pra coiê. Daí o meu marido embrabeceu porque ele encomendou o rancho e ele não levou. Aí ele garrou e deixou tudo e saímo. Saímo, viêmo pra cidade pagar aluguel. Agora o

38 O salto a que Adão se refere é o Salto Yucumán, a maior queda de água longitudinal do mundo, por onde passavam as balsas obrigatoriamente. Na sequência, o sobrinho de Adão, Hercílio, explica que a imagem das ovelhas branqueando é uma alusão às espumas das águas em queda. 
finado Davi, sim, foi um patrão bão. O Virmar Turcato, que é irmão desse cara também. Tem o alemão Turcato também, né. Só que esse que não queria fazer o rancho pra nóis era o mais novo da casa. Aí não queria fazer o rancho pra nóis, foi, foi, meu marido enjoô, deixou tudo lá e saímo. Não era fácil! Os pai dele eram rica pessoa, meu deus. E os outro irmão dele. Má ele era um safado. Lá no finado Davi, eles foram uma pessoa muito boa pra nóis. Eu, nóis trabaiava com eles, daí eu ajudava a tirar leite antes de ir pro serviço, né? Má eu ganhava queijo, salame, sabão pá lavar roupa... muitas coisa nóis ganhava deles, né? Eles faziam... aquelas panelada de comida e levavam lá pra nóis, não precisava fazer comida. Fôro pessoas muito boa. Finado Davi foi uma pessoa boa. Nóis ganhava pouco naquela época, pagavam pouco por dia. Nóis ganhava 2 pila, eu e o meu véio. É. Por dia. Aí quando foi um dia, o finado Davi disse - Ó, eu vou pagar 3 pila pra vocês por dia, mas vocês não vão contar pros outro peão, que daí eles vão querer também. Daí nóis fiquêmo quieto, eu e meu marido, ganhando 3 pila por dia. Tu vê, numa época que nem agora, quando que vão trabaiá por 3 pila? Má nunca! Foi sofrido.

\section{[Entrevistado: Orides Ramon]}

Nóis mesmo, nóis mesmo. Faço uma chaleirada, acendo umas brasa lá e já tomava. Por conta. Como é que diz: o nadador, se ele não sabe nadar e ele cai no rio, ele percura aprender, né? Tinha que percurá alguma coisa, né? Tudo que é erva. Porque erva do mato, é rara aquela que não é boa, né? Tudo nela é bom. [Mulher: É que naquele tempo ninguém ficava doente. Eu conheci o médico, eu tinha... acho que mais de 30 ano. Nem conhecia médico]. Eu tinha 18 ano quando eu conheci o doutor de Iraí. Conheci, não. A minha mãe falou que nóis tinha que ir lá, fumo... Fiquêmo lá, não vimo esse tal de doutor, viêmo, saímo de lá... - Má mãe, a senhora trouxe nóis pra conhecer o doutor, nóis não vimo... - Não, má era aquele hôme de branco, de roupa branca que entrou lá e falou comigo. - Não, má aquele lá é um hôme não é doutor! Nóis não conhecia, né? - Má aquele lá é um hôme, mãe, não é doutor não. - Aquele é o senhor doutor. Naquele tempo era tudo 
senhoria, né? Ninguém tratava que nem hoje, né? - Aquele é o senhor doutor! Mãe, mas era um hôme! Era o senhor doutor!

\section{[Entrevistado: Amantino dos Santos]}

Diz que lá pra cá de São Borja tinha uma sereia que passava no Uruguai. Tinha aqueles negócio de água, aquelas cachoeira braba, diz que eles passavam e tinha um poço muito grande. Pra cá de São Borja, diz que ali que sentava em cima de uma pedra e cantava. Diz que eles levavam violão, levavam gaita e quando ela cantava, diz que ela... deixava o pessoal tudo bobo com a cantiga. Diz que canta muito bem, diz que é uma moça, né? Que virou peixe. Da cintura pra baixo é um peixe, né? Diz que ela sentava em cima de uma pedra e cantava e encantava os barsêro e daí eles ficavam bobo de ver e daí não prestavam atenção na barsa, né? Dali quanta gente morreu, prestava atenção na cantiga daquela baleia, que fosse, e perdia o rumo. Então eles começavam a bater lata e dêle gaita e grito e tudo pra ela não tomar a atenção do povo. Senão eles morriam tudo. Tinha um lugar muito perigoso ali. Então naquela época eles contavam causo que a gente morria dando risada, né tchê? Diz que o pessoal se encantava, diz que uma moça muito bonita, né tchê? Diz que ela encanta mesmo. Diz que quando eles chegavam perto ela... ia ao fundo, não aparecia. Parecia lá muito longe, lá ela sentava de novo e cantava. E eles se embelezavam, né? Queriam ver de perto mas ela nunca deixava chegar perto. Só de longe que enxergavam. Diz que antigamente era... Acontecia, naquela tinha bastante tipo de bicho. Lobisôme. Tinha lobisôme também. Gostava de assustar o povo, de sexta-feira, quarta-feira à noite, né? Gostaria de brigar com os cachorro ao redor da casa. Baita cachorrão. Um lobisomezão. Aí diz que lobisôme é gente, né? Vira hôme. Diz que naquela época tinha lobisôme. E existe até hoje em dia, né? Lobisôme... Ah, existia também aquelas bruxa, antigamente né? Que tomava vinho nos vinhal, né? Existia! Aqui tem uma época que nóis ia morar aqui em Santa Antônio e existia, né? E passava sempre, cantando, e ia tomar vinho onde tinha pipa de vinho, que antigamente plantava os vinhal, né? Aí decerto descobriam e iam lá tomar vinho. Diz que até um tempo o dono do vinho diz que um dia foi tirar vinho lá, numa sexta-feira encontrou uma, lá. Bêbeda. Só 
ela tava nua, sabe? Elas sai nua, né? E avoam. Sempre em duas, duas. Elas passam cantando. E vortam cantando, né? Então o finado Nôno Amélio me contava esses causo, que aparecia demais essas bruxa, sabe? Iam lá bebiam e decerto se esqueciam, né, e tomavam demais. Uma sempre ficava. Daí, causo do tempo antigo, né? Isso aí é que acontecia. Hoje em dia não acontece mais nada. Mas acontecia esses causo.

\section{[Entrevistado: Orides Ramon]}

O Caibi, Caibi não era pra ser o nome de Caibi. Era pra ser São Domingos ou Folhas Verde. Má daí veio um hôme véio bem de idade, de lá com nóis e veio, e nóis tava num caçamba e oiando, e abrindo as picada, e tinha... nóis não vimo que tinha uma peralzote pra baixo assim e o véinho caiu por cima agarrado, e nóis gritava e o nome dele... o nome dele começava com Caibi, o nome dele. Veio do Rio Grande. E nóis gritava - Tio Caibi! Naquele tempo chamava tudo de tio. - Tio Caibi! O senhor não se machucou, o senhor tá vivo, Tio Caibi? E nóis falêmo pro Nôno Bigatão. - Nôno, óia, o nosso lugar tinha que botar o nome de Caibi. Caiu o Tio Caibi lá e nóis comecêmo a gritar. E o Nôno tinha um lápi e uma fôia de... aqueles papel de embruio, se alembra que tinha uns papel de embruio pra botar o quilo, o meio quilo, cem grama, quê que você comprava de poquinho também, né? Ele pegou e anotou ali. Botou no borso, o nome anotado. E ele ficou com aquele papelzinho no borso lá e, um dia, ele falando... - Nóis vamo botar o nome de Caibi nesse lugar aqui. E era um hôme véio que caiu num peral, que nóis gritava Caibi, Caibi! Não tá morto, Caibi? Ô Tio Caibi! Nóis truxêmo ele com nóis. Um véinho muito... naquele tempo tudo era tio, né? Ninguém chamava, né?, tu, você, não existia essa palavra.

\section{[Entrevistado: Orides Ramon]}

O meu pai era natural de Sobradinho e a minha mãe era natural de Monte Negro.O pai era fío de um alemão com uma negra africana. O pai do meu pai era alemão da Alemanha e a mãe do meu pai era negra da África... africana! E a minha mãe era índia. Descendente de índia, minha mãe. Minha mãe era índia. Não podia tá muito 
misturado com eles, porque eles não eram muito de tu tá... O índio até hoje ele gosta de tá meio separado mesmo. Tem índio esperto, mas tem outros que não qué tá no meio. Então nóis ficava no nosso lado, eles nos deles, né? Ninguém se metia com eles. Ninguém brigava naquele tempo lá. Era coisa muito boa de viver. [Vizinho: Cuidava pra não invadir o espaço]. Não, eles ficavam meio assim, né? Porque a aldeia mêmo deles ficava... aqui nesse lugar nem tinha, tinha em Cunha Porã e Rio Grande. Em Cunha Porã tinha a aldeia deles ali. Tem uma história, né Dirlei?, que quem estudou sabe disso. Que diz que quem descobriu o Brasil foi Pedro Álvares Cabral, mas quem descobriu o Brasil foram os índio. [Dirlei: Já era, né?] Só que daí... ali, ali, não sei agora, porque a gente não chegou a estudar, né? Quem estudou deve saber mió. Mas ainda, ainda, eu fico do lado da indiada, porque eu tenho sangue de índio por causa da minha mãe, né? Eu fico do lado dos índio.

\section{[Entrevistado: Amantino dos Santos]}

Naquele tempo não tinha médico, nada. Naquela época era só chá do mato. Minha mãe sabia fazer. E quando ela não sabia, tinha os índio antigamente. Os índio véio, bem veínho. Tinha, tinha. Tinha desde aqui em Iraí tinha o tordo ali. Ainda tem ali em Iraí o tordo, né? Aparecia os velhinho lá, vendendo balaínho, né? Então tinha um filho doente, eles pediam... - Ô, sabe fazer um cházinho que o meu fío tá doente. Ela dizia, - Eu sei, vizinho! Diz, - Eu vou ali no mato e já vórto. Vinha com aqueles feixe de mato. Bota cozinhá ali, que daqui a pouco... ferve lá e daqui um pouco esfria e dá pro fío tomar que daqui a pouco já fíca bom, né? E hoje em dia, né? Hoje em dia tu não vê um índio doente, né? Pé no chão e, hoje em dia, nóis viêmo aí tudo cheio de doença por causa do quê, né?[Dona Olga: Tinha uns índio que trabaiavam com nóis na roça. Eles roçava, carpia... Era bom de trabalhar com eles, depois tu pega conhecimento com eles é bom de trabalhar. São mais obediente que uma pessoa branca. Eu aprendi com eles a fazer uns chá, um xarope pra bronquite, pra vermes. Eu tinha o Vanderlei, o meu piá, tinha levado ele no médico. Ele vivia mais dentro do hospital do que em casa. Aí veio uma índia e disse, - Dona Olga eu vou te ensinar um remédio. Aí fumo pro 
mato catá chá. E eu fiz um litro e uma garrafa daquele remédio, também nunca mais. Curei o piá!] Isso é coisa boa. Tem o conhecimento. E hoje em dia ninguém mais faz chá de mato, né? Só médico e médico.

\section{[Entrevistado: Francisco Antunes de Andrades Filho]}

Encontrei panela de índio aqui no Rio Grande. Aqui no Rio Grande encontrei. Ali em São Domingo. No que passa o Uruguai. Nóis tava lavrando até, foi um cunhado meu... nóis tava lavrando e ele enroscou o arado. E o arado RRRRR eu disse, - $\mathrm{O}$ quê que tem aqui? Não tem pedra! Passou o boi pra trás e carcou mais, alevantou. Era uma panela de barro. Índio era reveria, índio vivia com eles. Com os índio isso era coisa que eu vivia com eles. A aldeia deles era aqui na... adiante aqui em Rodeio Bonito. Ali tinha área, tem!, até hoje tem a área deles. De noite que deito no sofá assisti... começo a relembrar o tempo que eu convivi com os índio. Tempo bom, rapaz! Tempo bacana. Eu ia na aldeia e eles vinham lá em casa, porque nóis era, nóis tinha uma relação muito boa, né? Eles vinham. Má, nóis ficava lá papeando, tomando trago, oiando eles fazê balaio e eu coiêndo conversa deles. Puxando por eles, pra ver como é que saía, há! [Dirlei: Mas tinha umas indiazinha ou não?]. Não, não, não tinha nada. Até tinha um índio, Francisco... nunca esqueço o nome dele: Francisco Kairó. Era um índio véio. Ele tinha... a terra dele era dentro de Rodeio Bonito, passava o rio da Vargem. Tem um lugar lá... eu nasci e me criei conhecendo por esse nome, Bocó. O rio faz uma encenada assim, quase fecha. Quase fecha e depois fica aquilo... lugar muito espaçoso. Então lá é uma área deles. Ali pega de Rodeio Bonito vai a Nonoai, a área deles. E lá de Nonoai pra frente vai a Passo Fundo. É só deles. Até eu tava, eu tive lá em Nonoai. Tive várias veiz, mas eu tinha uma relação com aquela bugrada, mas uma relação, rapaz! Porque eu sei preparar a cama pra mim dormir.

\section{[Entrevistado: Francisco Antunes de Andrades Filho]}

Dava, dava, coisa assim... você morava na área e eu também. Nóis dois, morando dentro da área indígena. $\mathrm{E}$ de nóis se desafiar, mode de divisa de terra. Isso dava. Porque uma veiz, eu tava, eu andava morava lá no Pinhal. Mas eu era... tinha uns 7, 8 ano. E fui lá pro Saltinho do Café, lá pra cima. E lá me achei com um colono 
lá e ele me diz, - Óia, eu tenho uma meia colônia de terra pra vender. Dizia, - Tá na hora, o fumo tá quase bom pra coiê. Aquele...mas garpão, rapaz, mas garpão! Tudo coberto de tabuinha. Casa, tudo, coberto de tabuinha. Tudo quanto era coisa coberta de tabuinha. E uma terra, rapaiz! Mas uma terra roxa, coisa mais linda, coisa mais linda! Eu vim pra casa...digo, - Mas óia, no fim da semana que vem eu tô aí de novo. Ele queria 5 conto. Carregava uma mudança e deixava a planta que tinha, ficava tudo. Tenho que fazer esse negócio. Fui pra casa. Minha vó, tudo que eu fazia, ela aceitava. Digo, - Vó, tem uma área de terra, meia colônia de terra, no tal Rio Martel, é o nome do lugar. Tinha uma (inaudível) que escorria e formava um jatinho. Digo, tem uma meia colônia de terra lá no Rio Martel e tem um hômem que quer vender, quer 5 conto. Tem um eito de fumo plantado, tem milho, tem feijão, tem de tudo! Ele deixa tudo. Disse, - Vamo lá oiá! E no fim de semana vamo lá oiá. - Tá bom, vamo. Vendêmo aqui e compramo lá. -Vamo. Uhum. No fim de semana nóis enchemo dois cavalo e se boliêmo. Cheguêmo lá, foi dado um velório de um deles, um matou o outro por causa de divisa de terra. Os dois colono. Os índio não faziam nada. Eram gente boa. Só, na verdade, quiser tirar eles pra peteca, aí a coisa não funcionava. Aí a coisa funcionava. Mas senão... Daí chegamo lá, acontecendo um velório, - Ué o que que deu? Dizem, Um matou o outro aí por modo de divisa de terra. Um queria pegar mais terra que o outro, diz, - E não é eles, isso é dos índio. Diz, - Eles tão aí acampado. Dizia, O dinheiro que entrar pra eles é bão. Digo, - Ah é? Então quem não vai com.., quem nem lá não vai sou eu. Vou comprar coisa que não tem documento nenhum? Lá onde eu moro tem documento. Mesma coisa (inaudível). [Dirlei: Por isso que o preço era bom, mas era meio no grito...]. É, não, não. Eu digo não. E até hoje, eu adoro os índio. Adoro demais os índio, dou muito apoio. Até tem umas índia que seguido tão por aí. Digo ó, vocês querem comer? Peguem aí e façam, porque eu não faço. Vem de Iraí. 